\title{
Cyprus Between Late \\ Antiquity and the Early \\ Middle Ages (ca. 600-800)
}

AN ISLAND IN TRANSITION

Luca Zavagno 


\section{Cyprus between Late Antiquity and the Early Middle Ages (ca. 600-800)}

Research on early medieval Cyprus has focused on the late antique "golden age" (late fourth/early fifth to seventh century) and the so-called Byzantine "Reconquista" (post-AD 965) while overlooking the intervening period. This phase was characterized, supposedly, by the division of the political sovereignty between the Umayyads and the Byzantines, bringing about the social and demographic dislocation of the population of the island. This book proposes a different story of continuities and slow transformations in the fate of Cyprus between the late sixth and the early ninth centuries.

Analysis of new archaeological evidence shows signs of a continuing link to Constantinople. Moreover, together with a reassessment of the literary evidence, archaeology and material culture help us to reappraise the impact of Arab naval raids and contextualize the confrontational episodes throughout the ebb and flow of Eastern Mediterranean history: the political influence of the Caliphate looked stronger in the second half of the seventh century, the administrative and ecclesiastical influence of the Byzantine empire held sway from the beginning of the eighth to the twelfth century. Whereas the island retained sound commercial ties with the Umayyad Levant in the seventh and eighth centuries, at the same time politically and economically it remained part of the Byzantine sphere. This belies the idea of Cyprus as an independent province only loosely tied to Constantinople and allows us to draw a different picture of the cultural identities, political practices and hierarchy of wealth and power in Cyprus during the passage from Late Antiquity to the early Middle Ages.

Luca Zavagno received his BA degree in History from the University Ca'Foscari, Venice; he completed his $\mathrm{PhD}$ studies at the University of Birmingham on the society, culture, economics and politics of Byzantine cities. He is Assistant Professor in the Department of History at Bilkent University. Dr. Zavagno is the author of many articles on the Byzantine and early Medieval Mediterranean and of the co-edited volumes Islands of the Eastern Mediterranean: A History of Cross Cultural Encounters (2014), Goods on the Move: Merchants, Networks and Communication Routes in the Medieval and Early Modern Era (2016) and of Cities in Transition: Urbanism in Byzantium between Late Antiquity and the Early Middle Ages (2009). 


\section{Birmingham Byzantine and Ottoman Studies}

\section{General Editors}

Leslie Brubaker

Rhoads Murphey

John Haldon

Birmingham Byzantine and Ottoman Studies is devoted to the history, culture and archaeology of the Byzantine and Ottoman worlds of the East Mediterranean region from the fifth to the twentieth century. It provides a forum for the publication of research completed by scholars from the Centre for Byzantine, Ottoman and Modern Greek Studies at the University of Birmingham, and those with similar research interests.

For a full list of titles in this series, please visit https://www.routledge.com/ series/BBOS

\section{Imperial Lineages and Legacies in the Eastern Mediterranean}

Recording the Imprint of Roman, Byzantine and Ottoman Rule

Edited by Rhoads Murphey

\section{Dreams and Lives in Ottoman Istanbul}

A Seventeenth-Century Biographer's Perspective Aslı Niyazioğlu

Byzantium and the Emergence of Muslim-Turkish Anatolia, ca. 1040-1130 Alexander Daniel Beihammer

Cyprus between Late Antiquity and the Early Middle Ages (ca. 600-800) An Island in Transition

\section{Luca Zavagno}

A Tenth-Century Byzantine Military Manual: The Sylloge Tacticorum Translated by Georgios Chatzelis and Jonathan Harris

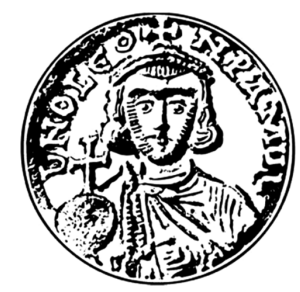

Centre for Byzantine, Ottoman and Modern Greek Studies University of Birmingham 


\section{Cyprus between Late Antiquity and the Early Middle Ages (ca. 600-800) \\ An Island in Transition}

Luca Zavagno 
First published 2017

by Routledge

2 Park Square, Milton Park, Abingdon, Oxon OX14 4RN

and by Routledge

711 Third Avenue, New York, NY 10017

Routledge is an imprint of the Taylor \& Francis Group, an informa business

(C) 2017 Luca Zavagno

British Library Cataloguing in Publication Data

A catalogue record for this book is available from the British Library

Library of Congress Cataloging in Publication Data

A catalog record for this book has been requested

ISBN: 978-1-138-24331-6 (hbk)

ISBN: 978-1-315-27736-3 (ebk)

Typeset in Times New Roman

by Taylor \& Francis Books

Birmingham Byzantine and Ottoman Studies Volume 21 
To my Princess Sofia 
This page intentionally left blank 


\section{Contents}

List of figures viii

Preface ix

Abbreviations $\quad$ xi

1 Mattia Pascal and the name of Cyprus 1

2 Seeing the unseen: a brief overview of Cypriot historiography 15

3 The mousetrap of methodology 29

4 A history of Cyprus in the early Middle Ages 64

5 Urban versus rural: the many sides of the Cypriot coin 113

6 An insular economy in transition 155

7 Aftermath and conclusions 181

Bibliography 194

$\begin{array}{ll}\text { Index } & 223\end{array}$ 


\section{Figures}

1.1 A map of Cyprus 3

2.1 Amathos: Agora as seen from the Acropolis 19

3.1 The Basilica at Soloi 41

4.1 Salamis-Constantia: Ruins of the Basilica of Saint Epiphanios 76

4.2 Church of Panagia Kanakariá in Lythrangomi 99

5.1 Salamis-Constantia: Mid-to-late seventh century walls encroaching onto the Cardo Maximus 139

5.2 Lapethos: Acropolis 141

6.1 Eighth century Church of Aphendrika (Ourania-Aphendrika, Karpas Peninsula) 158

6.2 Salamis-Constantia, Huilerie complex 171 


\section{Preface}

Hannah Arendt once said that the best remedy to the unpredictability of fate, to the chaotic uncertainty of the future, lies in the human faculty of making and keeping promises. ${ }^{1}$ Therefore, I tend to regard this book as the fulfilment of a seven-year promise made to many people and institutions, who since 2009 have believed in my capacity for fulfilling it despite my inability even to picture the final outcome of my research on seventh- and eighth-century Cyprus. To begin with and proceeding in a strict chronological order, I am enormously indebted to John Nesbitt and Cécile Morrisson, who accepted me into the 2009 Sigillographic and Numismatic Summer School at Dumbarton Oaks Library and Research Center; indeed, their insights and teachings gave me the inspiration to write a first article on the coinage of the island of Cyprus in the passage from Late Antiquity to the early Middle Ages and to start building up a serious bibliography on the topic. Once back in Cyprus, I also benefited from the advice and guidance of former and current colleagues such as Özlem Çaykent, Jim Kusch, Can Sancar, Michael Walsh, Matthew Harpster, Bülent Kizildüman, and Mehmet Erginel, who encouraged me to broaden my horizons beyond numismatics and sigillography to pursue an all-encompassing book on seventh- and eighth-century Cyprus.

This concept was developed during the two summers I spent at Dumbarton Oaks, first in 2010 as a bursary recipient and then in 2011 as a Summer Fellow. There I finally developed the guidelines of my project with the support and advice provided to me by the entire scholarly community. Here my deepest and warmest thanks go to Margaret Mullet (a unique and continuous source of positive energy), Jonathan Shea, Deborah Brown-Stewart, Alberto Rigolio, Annemarie Weyl Carr, Scott Johnson, Örgü Dalgıç, Juan Signes-Codoner, Ida Toth, and Vasileios Marinis. I regard myself lucky to have had the opportunity to share some of my ideas with these friends and colleagues and to have received their feedback.

I must also thank a second institution, which played an enormous role in finalizing the project and providing me with a welcome respite from my teaching duties at Eastern Mediterranean University and later at Bilkent University (which I also thank for their unwavering support). In granting me a Fellowship in the Fall of 2012, the Stanley Seeger Center for Hellenic 


\section{x Preface}

Studies at Princeton University, and in particular its executive director Dimitri H. Gondicas, gave me the opportunity to interact with an extraordinary constellation of local scholars from diverse walks of academic life and areas of expertise. Here my gratitude goes to John Haldon, Ravi Shankhar, Helmut Reimitz, Patrick Geary, Peter Brown, and Molly Greene for their invaluable criticisms and comments to my work in progress.

As my research benefited enormously from these experiences, I at last reached the final stage of my project, the moment when the promise should have been fulfilled. However, writing the book was not easy and took me longer than expected. This should account for the fact that the period in which my evidence was collected stopped in 2014 with less systematic updating later on. During the writing phase I was lucky enough to have some local and long-distance support and encouragement on the part of colleagues (some of whom I am proud to call friends) who read and commented on sections of the book. First and foremost, I should thank Hawley Kusch and Lisa Shea for going through the rough draft of the book for a painful (due to my terrible English) editing process. I would like to mention Nicholas Coureas, Nikos Bakirtzis, Günder Varinlioğlu, and Chris Wickham. The last in particular I will always regard as my mentor and source of constant inspiration. There will never be enough words to express my enormous gratitude to him for having been there at any important moment of my life.

Finally, I must also thank all the people who have been followed and supported me during this long journey, family and friends alike. From my endless love Federica, wife and companion of a lifetime, to my daughter Sofia, who has always tried to convince me that an itsy bitsy spider should be included in one of my chapters; from my mum, who is always there to rally my morale with patience and infinite love, to my sister Marianna, whom I miss more than I like to admit; from Şevin and her curly way of life to Marios, Aysu, my "only" brother in law Antonio, Massimiliano, David, Michele, and Steve, who all taught me that true friendship can travel across space and time; from Marcello and Mariangelo, who showed me what fatherhood really means to "my captain" Antonio Capitanio, who first introduced me to "History." Finally, I would like to thank my beloved and best Teaching Assistant Zeynep, my "students" Harun, Asad, Humberto, Ela and Mert, as well as Minnie, Aedo, Nathalie, Ivanhoe, and Woody: "tailed" friends who did not all have the chance to see this long journey reach its conclusion. To all of the above this book is ideally dedicated. You will be in my heart always and forever. And this is another fulfilled promise.

Ankara, July 2016

\section{Note}

1 H. Arendt, "What is Freedom?", in H. Arendt, Between Past and Future (London, 1968), p. 164. 


\section{Abbreviations}

AASS Acta Sanctorum Documenta Catholica Omnia ad Mignum Intelligendum. Société des Bollandistes.

$\mathrm{AB}$

AN

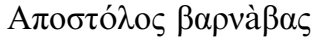

AnBoll

$\mathrm{ABzF}$

Anadolu

AR

AS

Byz

$\mathrm{BCH}$

BHG

Analecta Bollandiana

Acta Byzantina Fennica

Archaeological Reports

Anatolian Studies

Byzantion

Bulletin de Correspondence Hellénique

Bibliotheca Hagiographica Graeca. Ediderunt sociii

Bollandiani. Brussels 1909.

BMGS Byzantine, Modern Greek Studies

$\mathrm{BF}$

Byzantinische Forschungen

$\mathrm{BZ}$

Byzantiniche Zeitschrift

CCRB Corsi di Cultura sull'arte Ravennate e Bizantina

$\mathrm{CSCO}$

Corpus Scriptorum Christianorum Orientalium

CSHB

DAI

Corpus Scriptorum Historiae Byzantina edition emendatior

et copiosor consilio B.G. Niebuhrii.

DOP

EB

De Administrando Imperio

Dumbarton Oaks Papers

EKEE

IJA

$\mathrm{K} \Sigma$

Études Balkaniques

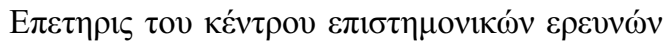

International Journal of Archaeology

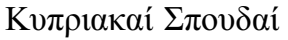

JMA Journal of Mediterranean Archaeology

JEMAHS Journal of Eastern Mediterranean Archaeology and Heritage Studies

JHS Journal of Hellenic Studies

JRAS Journal of Royal Asiatic Society

JSAH Journal of the Society of Architectural Historians

Mansi J. D. Mansi, Sacrorum conciliorum nova et amplissima collectio (Paris-Leipzig, 1901-27) 
xii Abbreviations

MHR Mediterranean Historical Review

NC Numismatic Chronicle

PG Patrologiae Cursus Completus: Series Graeca/ accurante J.-P. Migne. Parisiis. tomus 1 (1857) - tomus 161 (67).

PL Patrologiae cursus completus. Series Latina / accurante J.-P. Migne. Parisiis. tomus 1 (1844) - tomus 221 (1864), reprinted in the $1880 \mathrm{~s}$

RDAC Reports of the Department of Antiquities in Cyprus

TM Travaux et Mémoires 


\section{Mattia Pascal and the name of Cyprus}

In the introduction to his masterpiece, Mattia Pascal, Pirandello writes that the only thing that the main character of the novel knew was his name.

One of the few things, indeed the only one that I know for certain is that my name is Mattia Pascal. I used to take advantage of this. Every now and then a friend or acquaintance was foolish enough to come to me asking for some suggestion or advice. I would shut my eyes slightly, shrug, and answer: 'My name is Mattia Pascal.' - Thanks a million. I knew that 'Yes, yes I know that much.' And does it seem so little to you.' 'To tell you the truth, it didn't seem a great deal to me either.'

When I started my research on Cyprus in the passage from Late Antiquity to the early Middle Ages, I caught myself in the same state of mind as Pirandello's character. Although a number of important historiographical syntheses on Cyprus in the period under consideration have been published, they seem to me not sufficiently concerned with a comprehensive approach and not fully focused on a systematic analysis and contextualization of the volume of information stemming from different types of primary sources (literary, documentary, and material). Rather, as will be seen, their concern has mainly been to describe the internal history and fortunes of the island in terms of a catastrophic decline and depopulation from the mid-seventh century onwards. As a result of such a descriptive narration, however, they leave the reader to draw the most obvious conclusions about the patterns of discontinuity in the history of Cyprus. Furthermore, because they mainly wish to zoom in on the dramatic and disastrous events that shaped the lives of the local inhabitants, more often than not those calamities are identified, too easily, with the Arab incursions of 649 and 653. According to these sources, after these dates, what we supposedly know about Cyprus is a little more than its name.

Indeed, the idea that the Arab conquest permanently broke the unity of the Mediterranean turning it into a permanent frontier is not peculiar to Cyprus and hearkens back to Henry Pirenne's Mohammed and Charlemagne. This idea has been challenged and reappraised (particularly in the light of new archaeological evidence) since its first appearance in $1936 .{ }^{2}$ In the case of 


\section{Mattia Pascal and the name of Cyprus}

Cyprus, the Arab raids have often represented a real watershed moment in the historiography of the island, which often assumes the chronological division of Cypriot early medieval history into three periods: the Late Antique "golden age" (late fourth/early fifth to seventh century), the so-called Byzantine Reconquista (post 965), and the period in between, which is more often than not regarded as the Cypriot Dark Ages. As most attention has been paid to the "golden age" and the Reconquista periods (although the impact of the Byzantine return to the island has started to be debunked), the narrative on Cyprus in the early Middle Ages has been limited to few general topics: above all, a forced (and in fact abortive) transplantation of population to the Hellespont, the encompassing political and religious role of the local autocephalous Archiepiscopal Church, and a treaty dividing the tax revenues of the island "betwixt the Greeks and the Saracens", that is, between the Umayyads and the Byzantines. ${ }^{3}$ The treaty, dated to $686-88$, supposedly brought about an era of shared political sovereignty between the Umayyads (and later the Abbasids) and the Byzantines. This period, sometimes called condominium, buffer zone, or no man's land, was regarded by historians as tantamount to a sterile neutralization of the social, economic, and even cultural life of the island. According to these authors, it is only after the Arab invasions and the condominium on the island from late seventh century to $963 / 4$ that a real blossoming of architecture and religious painting can be traced. ${ }^{4}$ Long gone were the days in which "her [Cypriot] inhabitants toiling their land and trading with foreign nations, were growing in both prosperity and wealth [and] founding temples and churches, building magnificent dwellings". 5

Indeed, in the last few decades, scholars like Andreas Dikigoropoulos, Konstantinos Kyrris, Arthur Megaw, Joannic Durand and Andrea Giovannoni, Robert Browning, Sophocles Hadjisavvas, Vassos Karageorghis, and (at times) Marcus Rautman and David Metcalf have drawn a picture of the period from the late seventh to the early ninth century characterized by repeated destruction, the end of urban life, relocation to inland settlements with fundamental changes in land-use patterns, increasingly rural economic life, and the social and demographic dislocation of the elites, the ecclesiastical hierarchies, and the remaining population of the island. ${ }^{6}$ In other words, the historiography of early medieval Cyprus often deliberately flirts with catastrophe. ${ }^{7}$ However, one must recognize that this long-established approach cannot be fulfilling if one wants to properly analyse the historical development of Cyprus in the transition from Late Antiquity to the early Middle Ages through the new cross-disciplinary analysis of different documentary and archaeological materials. ${ }^{8}$

In my view, scholars who have focused their attention on seventh- and eighth-century Cyprus have been too influenced by the image drawn by the literary and documentary sources alone. It is not that archaeology is completely missing from these syntheses; moreover, a series of conferences held in the Republic of Cyprus in the last few years have indeed brought scholarly attention to the results of field surveys and of urban and rural excavations 


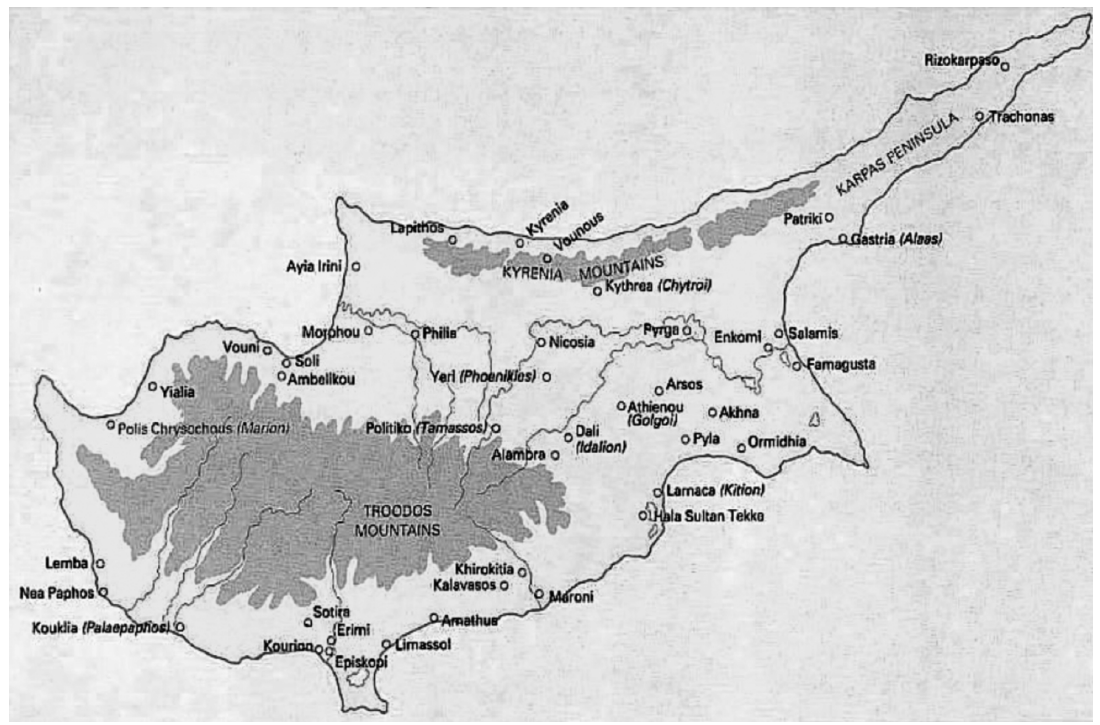

Figure 1.1 A map of Cyprus

together with an up-to-date analysis of material evidence. ${ }^{9}$ However, more often than not the contributions on Cyprus in the passage from Late Antiquity to the early Middle Ages fail to notice the important ways archaeological conceptualization of the passage of time might contrast with that created by a textual historian. This is not to deny that cross-disciplinary boundaries between archaeology and history are very blurred, but simply to assert that one cannot engage with contemporary textual sources as a means to clarify patterns of data recovered from excavations and surveys or use numismatic and archaeological information to address gaps in the written sources. ${ }^{10}$

For instance, the reduction in coin finds and the dwindling of imported fine wares and amphorae in all excavated urban and rural Cypriot sites has been often interpreted simply as evidence for a retreat of the local population into a more localized economy due to the catastrophic Arab raids. ${ }^{11}$ Evidence from lead seals and coins has also been used recently to propose the existence of a real north-south divide in the "treaty centuries" (i.e. from 688 to 965), which should help us explain how the condominium regime worked on the island. ${ }^{12}$ Here, the risk is that of bolstering a picture drawn by documentary sources, more often than not one concerned with raids and punitive expeditions against the island or the predominant role of the Church as a bulwark of the Cypriot religious (and partially political) independence, ${ }^{13}$ but it is a conclusion derived from these sources, and not independent from them.

It is important to consider that the archaeological past seldom dovetails with the information retrieved from chronicles and other types of literary sources. ${ }^{14}$ The latter have often either escaped a real critique (for instance in the cases of the Byzantine hagiographies or the Arab sources commenting 


\section{Mattia Pascal and the name of Cyprus}

upon the above-mentioned treaty of 686-88) or have actually been misinterpreted, like the pro-iconophile accounts of the orthodoxy of the island. In other cases, the literary accounts have been deliberately exaggerated, as in the reports concerning the transplantation of the whole population of the island to Nea Justinianoupolis on the Hellespont in 691 or those presenting the ruinous effects of the Arab raids. Moreover, the so-called Cyprus problem (that is to say the de facto partition of the island after the 1974 Turkish occupation of its northern part) has often impinged upon objective interpretations of the period under consideration, prompting the scholarly community to accept the idea that the mid-seventh century ushered the island into an age of deprivation and decline. I will return to this later.

I am also perfectly aware that archaeology, too, has sometimes lacked a methodological critique. ${ }^{15}$ For instance, Tassos Papacostas stresses that archaeological surveys seldom pay attention to periods later than the Roman Empire and, therefore, rarely edge beyond the historiographical gap represented by the seventh century. Other surveys remained unpublished, as geographical bias does not allow us to use more than a small amount of literature on sites located in the northern part of the island. ${ }^{16}$ In other words (those of Timothy Gregory), it is ironic that one of the most silent periods of the history of Cyprus is also one of the most recent. ${ }^{17}$ Uncritical approaches, however, pave the way to flawed generalizations, such as those eager to depict Cyprus simply as a maritime continuation of the Arab-Byzantine frontier. ${ }^{18}$

In fact, as Dominique Valérian, Ralph Bauer, and Thomas Sizgorich have showed, we should reappraise the entire concept of borders in the medieval Mediterranean. This in the light of a larger Mediterranean analytical approach, which points to the construction of a shared medieval Mediterranean, disputed particularly, although not exclusively, between Christendom and Islam; a sea that remained a border between Christians and Muslims but marked at the same time by conflict and exchange. ${ }^{19}$ Moreover, the very ontological essence of the term border has been redefined by Sizgorich, who states:

Borderlands are often home to hybrids [which] incorporate and embody the tension of ungovernable and so irresolvable self-other dichotomies confined in a single entity. [However] they also housed individuals and communities who exploited their liminal status and who engaged in economies of various sorts ... which existed independently of the great powers between which they abided. ${ }^{20}$

Ninth and tenth-century Muslim cartographers like Ibn Hawqal enhanced this idea, for although they recognized the existence of political boundaries, they defined them as transition zones of uncertain sovereignty and identity where the force of one polity slowed faded away to be replaced gradually by the cultural, social, and political influence of the neighbouring state. ${ }^{21}$

As will be seen, these concepts of frontier and borderland resurface in the description of Cyprus as a middle ground, based upon the idea that cultures 
stem from the creative interaction of human populations and never from isolation. $^{22}$ This reflection takes on universal importance when one considers that this concept has been used to investigate the sixteenth-century interaction between the French and the native Algonquian-speaking people in the Great Lakes region of North America, describing a world that could not be further away from Byzantium and the medieval eastern Mediterranean in terms of geography, climate, social structures, economic infrastructures, cultural values, and religious beliefs. Nevertheless, the concept of a middle ground has a resounding methodological and interdisciplinary echo, for it nurtures the creation of a model for understanding interaction as a cultural process - a process located in a historical place and made possible by the convergence of certain infrastructural elements. These elements are a rough balance of power, a reciprocal need for what the other possesses, and the failure by one side to gather enough force to coerce the other into change. ${ }^{23}$

Insofar as the elements in question may be replicated in other places and other times, the concept of middle ground can be aptly applied to Cyprus in the transition between Late Antiquity and the early Middle Ages, when, as mentioned, the island found itself on the border between the Byzantine Empire and the rising Umayyad caliphate. This situation can also be regarded as quintessential of the medieval Mediterranean generally, which became a border between Islam and Greek and Latin Christendom while remaining a free sea because no one power could dominate the others. ${ }^{24}$ This is not to discount the violence of the period or to tell a utopian tale of peaceful multiculturalism, but rather to encapsulate Cyprus within a broader Mediterranean narrative. So one could therefore better grasp the political, military, and economic changes of balance, interpreted as moments of construction of modalities of interaction in a shared space controlling and regulating both exchanges and conflicts: a meeting point between two opposed political and religious spheres but also as a by-product of peculiar social, cultural and economic conditions. ${ }^{25}$ Indeed, the Cypriot middle ground was not simply a place of encounter but also the result of a creative process involving local elites, "foreign" Byzantine administrators, western pilgrims (like Willibald in the 720 s [see note 3]), and Arab merchants, all of whom acted as cultural brokers helping to construct and reinvent a new society through deliberate acts of mediation. ${ }^{26}$

In this light, we are encouraged to look at Cyprus - and at islands in general as a privileged zone of interaction and not simply as a cultural barrier between different empires. This view calls for a reassessment of the Byzantine insular world as a periphery. ${ }^{27}$ Indeed, it is possible to surmise that Cyprus, together with Sicily and, to a lesser extent, Crete, Malta, Sardinia, and the Balearics, acted as a third political and economic sphere between the Anatolian plateau and the Aegean Sea in the Byzantine Mediterranean. However, the identification of some parallel economic and political trajectories among these islands will not be used to counter the differences in the political, economic, and cultural rhythms of transformation, which characterized different insular sites in the passage from Late Antiquity to the early Middle Ages. On the 
contrary, this should allow us to reconsider the fate of Cyprus in light of the growing archaeological data produced from other insular contexts (like Sicily, Crete, and Malta), which seem to emerge as a distinct entity between the constitutive pillars (what Wickham defines as Byzantine heartland) of the eighth- to tenth-century empire: the Aegean vis-à-vis western Asia Minor ${ }^{28}$. Indeed, we must conclude that "when one writes of the region in the transition period, one should look for the nuances that differentiate between regions and sites and even between distinctive zones of the same sites. One should focus on variations and not only common perspectives". ${ }^{29}$

The above-mentioned geographical division of the so-called Byzantine heartland proposed by Chris Wickham is a good example of analytical differentiation. The Byzantine heartland should be regarded as oxymoronic: on the one hand, it was the focus of one of the largest and most complex political systems in the whole of Europe and the Mediterranean; on the other hand it paired two wildly different geographical zones: the Anatolian plateau and the Aegean. ${ }^{30}$ In fact, this partition has been even reappraised in terms of the vitality of urban economies in the two macroregions (and even beyond). As more archaeologists focus their attention on inland Anatolian cities like Amorium (and partially Euchaita), once regarded always as disrupted, these reveal a previously unsuspected economic continuity and social complexity more in line with that of sites located along the coast or even on the islands (like Ephesus or Gortyn in Crete). ${ }^{31}$ Although there are some caveats Amorium remained an exceptionally important military and political hub and some areas of the Anatolian plateau, like Cappadocia, did experience a real change of urban and rural life - one must admit that the earlier concept of uniform decline should be replaced with a more complex approach recognizing that societies deal with continuity or change "through the construction of successful adaptive strategies, which have the effect of transforming and re-equipping existing social structures to deal with new realities". ${ }^{32}$

This not only allows us to put a structural problem (a lesser degree of interconnection and more localized economies in the post-600 Mediterranean) in a regionally nuanced perspective but should also help to propose a more objective and functional definition of the very idea of transition. Rather than using the concept of transition to deny the idea of a crisis or to provide a synonym for transformation without tensions, I would rather use it to compare different social, political, and economic forms with no teleological implications, because "a transition is a time of passage between two periods, when conditions are ripe for a change in the socioeconomic system as framed within the changing political and administrative imperial superstructure". ${ }^{33}$

By adopting this analytical frame, Alan Walmsley has proposed a model of smooth transition to interpret the trajectories experienced by Syria and Palestine in the passage from Byzantine to Umayyad rule, that is from the 630 s to the 730s. Basing his conclusions on a detailed assessment of material culture (mainly ceramics and coinage) yielded by urban and rural excavations across the whole region, Walmsley has demonstrated that the Islamic 
conquest of Syria and Palestine in 630 brought about only a minimal degree of socioeconomic disruption in both towns and countryside because cultural traditions reacted but gradually to the new political status quo. ${ }^{34}$

The concept of smooth transition proposed by Walmsley clearly owes much to the important comparison of regional and subregional exchange networks. Walmsley's argument also grasps the resilience, functionality, and scope of regional trade networks, which mirror the development in social and political structures both at the elite and sub-elite level. ${ }^{35}$ Indeed, as John Haldon has recently stressed, from the early seventh century the whole Byzantine Empire was affected by the extreme militarization of the provincial fiscal system, while commercial networks and urban and economic life changed radically until, in the mid-eighth century, the situation balanced itself politically and economically. This change mirrors the material evidence of more local and regional productive and distributive networks and a highly regionalized hierarchy of settlement. ${ }^{36}$ With this in mind, and rather than considering Cyprus in its splendid isolation as most scholars have so far proposed, one should look at the island from a comparative perspective - a point of view that allows us to test and perhaps move beyond the conclusion that a localization of production combined with the ruinous Arab raids was tantamount to a regression of the Cypriot economy in the late seventh and eighth century. Additionally, we should be able to reverse this approach for the archaeological evidence, which seems to point to a less violent and disruptive phase in the island's history than is presented in the traditional historiographic paradigm. To execute this examination, I have chosen to concentrate on three crucial themes.

First, the chronological structure will move away from the conventional tripartite framework and focus on the period between 600 and 800. As a result, we will not walk the well-trodden paths of fourth- and fifth-century Cyprus, with its splendid early Christian basilicas and its high artistic achievements, like the famous mosaics of Salamis-Constantia and Paphos. ${ }^{37}$ Instead, our journey will start in the period of political calm and economic prosperity that followed the reign of Justinian I and move to the strategic role Cyprus played in events such as the Heraclian revolt (608-10) and the Persian War, as reflected in the literary and numismatic sources. However, as Peter Brown points out, we must remain aware that periods are subjective, as many of the basic dates scholars choose support a conventional narrative of the period. ${ }^{38}$ This is what has happened with the historiography of Cyprus, in which proposed dates favour a deceptive teleology. One should reject the perceived gaps brought about by the Arab invasions of 649 and 654, the treaty of 686-88, and the transplantation and return of the population from Nea Justinianoupolis in 691, which have often been used to build a picture of impoverishment, decline, and depopulation that supposedly lasted from 700 to 965 . In fact, in the seventh and eighth century most of the Cypriot urban centres remained important foci of local demand, even though the former landscape of public architecture fell into ruins, because Cypriot elites 
continued to reside in the cities. Effective city-level economic infrastructures connected towns to their rural hinterland, and the wealth of the countryside supported the functional coherence of the urban fabric.

My focus will then move to the so-called long eighth century (and briefly to the ninth and early tenth centuries) as a real turning point in the pattern of production, consumption, and distribution of resources and administration. ${ }^{39}$ In this way the situation in Cyprus will be linked once again to economic developments in the nearby regions of the eastern Mediterranean: Syria and Palestine. Indeed, in Syria-Palestine, as in Cyprus, scholarship has been challenged by an unresolved and puzzling dichotomy between the many types and frequencies of transitional coins known through the antiquities market and (in lower numbers) recovered through archaeological work. In Syria-Palestine, as in Cyprus, we have suffered from the practical limitations of poorly excavated and published material, which until recently impaired the creation of seventhand eighth-century ceramic typology and chronology. ${ }^{40}$ It is important to note that in Cyprus the full effect of a revised chronology of local ceramic production, although still in its infancy, has demonstrated that what was once thought to be an empty landscape after the seventh century was in fact part of long-reaching commercial exchange networks, although scale and frequency of such connections is difficult to quantify. ${ }^{41}$

In this light, the perceived "barrier" between Late Antiquity and the early Middle Ages in Cyprus (as defined by the gap between two prosperous trade cycles: the Roman one and the second one dated to the central Middle Ages) becomes just another effect of the traditional tripartite division of the island's history. In other words, it is almost entirely a construct of modern historians. Instead I propose a model of eastern Mediterranean regional, subregional, and interregional connectivity. The picture of Cyprus from the mid-seventh to the beginning of the ninth century will be drawn as a story of continuities and slow transformations: the stability of the economy which mirrored the coherent institutional and fiscal state order, and the vitality of commercial exchange, as linked with the Levant, Egypt, and southern Asia Minor as well as Constantinople and the Aegean. This in turn is reflected by the persistent importance of the local clergy and the archbishopric (as the island was also as a reference point along the pilgrimage routes of the eastern Mediterranean) and the endurance of the local elites (military and civic), who experienced the political pull of the Constantinopolitan court that affirmed and enhanced their social status and cultural self-identity. As a consequence, the long-standing questions about the treaty between the Umayyads and the Byzantines or the political status of Cyprus (as no man's land or buffer zone ante litteram) ${ }^{42}$ will become less prominent as we grasp fully the similarities with Walmsley's above-mentioned "smooth transition" in terms of political structures and, above all, material culture.

This introduces the second theme of the book. Attentive analysis of the patterns of production, consumption, and distribution of locally made and imported ceramics and the disappearance of Byzantine coins paired with the 
persistence of Arab-Byzantine coinage in the late seventh century to the mid-eighth century demonstrate not so much an economic catastrophe as a transformation of imperial fiscal structures. The presence of lead seals up to the mid-eighth century (and even beyond) and the incidence of glazed white wares in some excavated sites are both evidence of a continuing Constantinopolitan link. This disproves the very idea of Cyprus as an independent province loosely tied to Constantinople and more oriented towards natural output. It also proves that the localization of production, as shown for instance in the predominance of locally made table wares and amphorae, certainly points to a "ruralisation of production and use with less good quality, less costly products made by less skilled potters in a household production". 43 However, this does not necessarily imply that Cypriot society during this period should be regarded as ruralized, de-urbanized, or rarefied in terms of settlement density or centred mainly on small residential foci in the hinterland as result of the dislocation caused by the Arab raids. ${ }^{44}$ What this book will try to show instead is that this view has more to do with the relative invisibility of Cyprus in the Byzantine sources, the underdeveloped analysis of the Arabic sources, the lack of a proper and comparative analysis of locally made and imported pottery, and the absence of proper archaeology in the northern part of the island in the last forty years than with the geographical range and complexity of exchange and the levels of local demand.

Hence I stress the importance of Michael McCormick's judgment:

Geographic and chronological trends of structures of exchange [find their] mirror in an independently preserved series of data on communication with economic components (movements of individuals, ceramics, coins): where they converge, we find market and trade. ${ }^{45}$

In seventh- and eighth-century Cyprus, this convergence resonates with the material evidence: the diffusion of Arab-Byzantine, Byzantine, and Islamic coinage, the continuity in production and importation of pottery, and the travels of pilgrims, diplomats, and merchants. This should come as no surprise if we consider that even when the capacity of the economy wanes, areas with adequate local resources may be able to retain a substantial level of continuity. ${ }^{46}$ The fertility of Cyprus (celebrated by Ammianus Marcellinus in the fourth century as well as the Arab geographer al-Muqaddasi in the late tenth century) and its strategic role as a hub along the shipping routes crisscrossing the eastern Mediterranean obviously played an important role in this continuity. $^{47}$

Indeed, we must consider that the fragmentation and localization of production and distribution provided Cyprus (as well as other islands, like Sicily, or coastal areas, like the southwest Anatolian coastline) with a unique chance to retain a far more complex economy as a middle ground between the economically coherent exchange circuits of Syria-Palestine and Egypt, the Byzantine capital, and the Aegean microregion (what I call three interlocking 
regional economies). ${ }^{48}$ As Cyprus played an important role as a hub on the less frequented and complex regional and interregional exchange routes, its economy benefitted from military expenditure (at least until the very end of the seventh century), aristocratic wealth mainly predicated upon the administrative and ecclesiastical functions, and the stability retained by the Byzantine fiscal system. In addition to regional exchange, the island also played an important role for the Arabs, as reflected in ceramic, numismatic, and epigraphic evidence. To a certain and certainly provocative extent, what mainstream historiography interpreted as cause (the Arab raids) should be interpreted as correlation, that is, a measure of relation between variables (these being the regionalization of Mediterranean economic exchange, the localization of aristocratic spending power in the Levant, the advent of a more provincially-based fiscal system in Umayyad Syria-Palestine, and the political weight of the Byzantine Empire). The combination of these explain why "throughout the late seventh, eighth and ninth centuries, Cyprus enjoyed [and benefited from] an unique position between the Muslim and the Christian worlds". 49

This encourages us to draw a different picture of the cultural identities, political practices, and hierarchy of wealth and power in Cyprus from the late seventh to the early ninth century; in delineating this distinctive feature, to paraphrase Peter Brown, one can never be circumstantial enough. ${ }^{50}$ The conventional narratives of political and ecclesiastical history, archaeology, evidence for circulation of coins and ceramics, inscriptions (like those found on eighth-century amphorae in Paphos bearing Arabic names), and tombstones (such as those yielded again at Paphos commemorating local Arab inhabitants) must be considered to create a complete portrayal of Cyprus in the transition from Late Antiquity to the early Middle Ages. ${ }^{51}$ Such a thorough examination reveals that the island was more of a piece with the fragmented eastern Mediterranean system of exchange and communications as shaped by the Arab conquest of Syria, Palestine, and Egypt than the simpler economic structure of the smaller Byzantine Empire.

Hence the third and final theme of the book: a brief comparison with other Mediterranean islands under Byzantine sway in the period under discussion, mainly Sicily and marginally the Balearics, Crete, and Malta. As will be seen especially in Sicily, which provides us with the best archaeological records among large Byzantine islands, we witness the persistence of wealth within the local civic, military, and ecclesiastical elites. ${ }^{52}$ A similar pattern may be seen on Cyprus, which shared common administrative, fiscal, military, social, and economic features with the other islands of the empire. Indeed, throughout Late Antiquity and beyond the large Mediterranean islands were characterized by favourable economic conditions. The possession by the Byzantines of a long insular corridor stretching from Cyprus all the way to the Balearics assured Constantinople a political and commercial waterway and a continuous link between the western and the eastern halves of the Mediterranean. ${ }^{53}$ 
Having spelled out the three main themes of the book, we should look at the overall framework of the socio-political, socioeconomic, and political-cultural developments of Cyprus from 600 to 800 . My intent is to offer a comparative view of economic and social changes based around the essential interconnectivity of many of the Mediterranean regions and microregions, which could achieve prosperity only when they interacted and connected with the others. ${ }^{54}$ This is not to deny that the Mediterranean may have boasted a less intense and more fragmented level of interconnection in the seventh and eighth centuries than in the fifth and sixth centuries but to stress that the localized differentiation underpinned by access to commercial routes and the fertility of the landscape could have allowed certain regions (and microregions) to retain a good level of continuity in economic and social life. ${ }^{55}$ This may show that the transformations of seventh- and eighth-century Cypriot economic structures, institutional orders, and social identities were less pronounced than has been previously thought.

However, these transformations can be fully grasped only if one first explores the complexity of the manifold theoretical, methodological, and practical approaches scholars have adopted to analyse the social, cultural, and economic conditions in Cyprus during the transition from Late Antiquity to the early Middle Ages. With this in mind, Chapter 2 tries to propose a historiographical framing and a backdrop against which a different history of the island can be viewed. This is achieved through the reconciliation of two opposing views: a long string of growth amid continuous Mediterranean connectivity (as enhanced by Peregrine Horden and Nicholas Purcell, and also partially by McCormick) and levels of demand underpinned by aristocratic spending powers (as inferred by Wickham and Haldon). ${ }^{56}$ As already mentioned, one possible solution is to regard Cyprus as lying at the heart of a series of interlocking economies, which would in turn reflect and impinge upon the Cypriot levels of consumption and the intensity of local production and regional exchange. Indeed, this approach is anchored in a detailed critical and methodological analysis of the sources. As will be shown in Chapter 3, this applies not only to literary sources written in Syriac, Arabic, and Greek (as Leslie Brubaker, John Haldon, David Robinson, Antoine Borrout, and James Howard-Johnston have pointed out) but also to the material culture regarded as essential to understanding the emergence of new cultural traditions and socioeconomic conditions. ${ }^{57}$

However, one should be aware that the latter concept can be fully grasped only within a detailed évenémentiel framework, which considers the major political events that occurred on the island in the period under scrutiny. These ought also to include the important role played by the ecclesiastical institutions (in primis the autocephalic archbishopric) in the history of the island. ${ }^{58}$ Thus Chapter 4 focuses on a more traditional narrative of the history of Cyprus, considering the development of the administrative and governmental structures of the Byzantine Empire and the local Church. Soon, however, the reader will move to a model and issues more archaeologically based, which 


\section{Mattia Pascal and the name of Cyprus}

sets the tone for the rest of the book. Chapter 5 examines the rural settlement pattern and urban sites (not least those located in the northern part of the island). Here, comparison with Syria and Palestine serves as a measure to re-evaluate the results of different rural surveys conducted on the island and to appraise the change of urban centres in Byzantine-controlled Cyprus. Chapter 6 deals with the economy of the island in terms both of state oriented (fiscal) economic activities and commercial networks (intra- and extraregional). Here the importance of the two main cogs of the economic engine (the local elites and administrative-bureaucratic structure) will be examined, while contextualizing the economic and social resilience of Cyprus within the Byzantine insular system characterized as the above-mentioned third typology between the Anatolian plateau and the Aegean. ${ }^{59}$ In this regard, Chapter 7 shows how these peculiar trajectories developed in the ninth and tenth centuries. This is what I called the "aftermath", which seems to demonstrate that the other extreme of the so-called Cypriot Dark Ages - the Byzantine return to the island - is more a perceived than a real caesura, evidenced by the continuous rhythm of local economy and the lack of changes in material culture. ${ }^{60}$

Finally, I should also stress that the term continuity will not be used to neutralize or discount the notion of change and transformation, but rather to counterbalance methodologically the dramatic catastrophism that has often gripped the history of Cyprus in the passage from Late Antiquity to the early Middle Ages. The radical downsizing and reorganization of the Empire stemming from the loss of the eastern Mediterranean provinces from 610 to 642, the breaking of the Egyptian tax spine, and the advent of a new ArabMuslim political power did not structurally undermine and determine the depopulation and de-urbanization of an entire island. ${ }^{61}$ Indeed, as Wickham states:

Where population continuities can be assumed so will continuities of daily life practices (and material culture)... These in themselves do not disprove the existence of crisis in other elements of a social system and political structures. One has to put them together and assess them as a whole, if one wants to get the sense of how social change as a whole has taken place. $^{62}$

Once this concept is grasped, it be less surprising to see how Cyprus seems only partially to fit into the interpretative picture of marked regional decline in supraregional Mediterranean trade and exchange from the mid-seventh century (with a nadir in the mid-eighth) and slow recovery starting in the 850 s. Although the island maintained strategic relevance for the Constantinopolitan administration (and most probably for the Umayyad polity), it also lay at the intersection of three regional economies that acted as stepping stones for cross-frontier and long-distance cultural and economic exchange as an island in transition at the periphery of two empires. 


\section{Notes}

1 Pirandello (2005), xiv.

2 Pirenne (1936); for the debate on Pirenne's thesis see, among others, Hodges and Whitehouse (1983); Hodges (1989), 6-28; McCormick (2001), 2-6; Wickham (2009), 221-2; Valérian (2014), 78-9.

3 Here I am borrowing the well-known comment used by an eighth-century AngloSaxon pilgrim named Willibald to describe the geopolitical status of the island. The expression was later made famous by scholars like Dikigoropoulos and Megaw who included it in the title of two of their contributions to the field (Dikigoropoulos (1961) and Megaw (1986), 505-19). For the source text, Hugeburc, Vita Willibaldi 1-2, in Talbot (1954), 161.

4 Sophocleus, (1994), 23.

5 Archimandrite Kyprianos (1788), 100.

6 Dikigoropoulos (1961); Megaw (1986); Karageorghis (1969); Kyrris (1985); Browning (2005); Rautman (2003); Hadjisavvas (2010); Metcalf (2009); Durand and Giovannoni (2012).

7 Chris Wickham included this remark in a paper entitled "Framing Early Medieval Cyprus", - which he presented at the Conference "And this island who knows it? Cypriot Identities across Millennia" held at the University of Nicosia from 7 to 9 September 2012. I am grateful to him for letting me use his paper, which remains unpublished.

8 Zavagno (2011-2012).

9 Parani and Michaelides (2013); Stewart, Davis, and Weyl Carr (2014).

10 Milwright (2010), 4.

11 Papanikola-Bakirtzis and Iacovou (1998), 9-20; Cameron, (1992); Rautman (1998).

12 Metcalf, (2014). As will be seen, this conclusion has been refused by Prigent (2012).

13 Metcalf (2009), 434-8.

14 Milwright (2010), 5.

15 Rautman (1990).

16 Papacostas (1999), I, 29. See on this Papageorghiou (2002), 63-7; also Papageorghiou (2011).

17 Gregory (1987), 199.

18 Lounghis (2010); Malamut (1988); also Metcalf (2009); Kennedy (2004); Haldon (2010a), 68-73.

19 Valérian (2014), 77.

20 Sizgorich (2004), 16-19.

21 Brauer (1995), 5-6.

22 White (1991), 1.

23 White (2006), 10.

24 Valérian (2014), 86.

25 Ibid., 78.

26 Abdellatif, Benhima, and Ruchaud (2012).

27 Vionis (2013a), 117

28 Zanini, Pergola, and Michaelides (2013); Laiou and Morrisson (2007), 43; Wickham, (2005), 32.

29 Patrich (2011), 59.

30 Wickham (2005), 32.

31 On the Euchaita/Avkat project and the preliminary reports on the survey see http:// www.princeton.edu/avkat/ (accessed 1 January 2015); Lightfoot (2012); Zavagno (2009), 164-9.

32 Walmsley (2007), 147. 


\section{Mattia Pascal and the name of Cyprus}

33 Giardina, (2007), 29-30.

34 Walmsley (2007), 48.

35 Walmsley (2012).

36 Haldon (2012a); Haldon (2012b); and Haldon (2016), 193-214; see also Wickham (2004).

37 Megaw (1974); Papageorghiou (1985a); Papageorghiou (1985b), 325-9; Daszewski and Michaelides (1988); Michaelides (2001); Michaelides (1987); Megaw, (1985); Ćurčić (1999).

38 Brown (2012), xxii.

39 Hansen and Wickham (2000).

40 Walmsley (2008), 320-1.

41 Armstrong (2009); Haldon (2012a), 105.

42 I am referring here to the post-1974 Cypriot divide and the so-called green line, the United Nations demilitarized zone. This stretches across the whole island and acts as a buffer zone between the Republic of Cyprus and the self-proclaimed Turkish Republic of Northern Cyprus.

43 Vroom (2011), 138.

44 McClellan and Rautman (1995), 85-6. Also Rautman (2003); Rautman (2005), 461. See also Chapter 5 of this volume.

45 McCormick (2012), 97.

46 Haldon (2012a), 122.

47 Ammianus Marcellinus, XIV, 8.14; al-Muqaddasis's excerpt is included in Cobham (1908), 5. For both sources see also Chapter 3.

48 Zavagno (2011-2012), 155.

49 Kennedy (2007a), 326.

50 Brown (2012), xxii.

51 Christides (2006), 113-21.

52 Nef and Prigent (2006); McCormick (2001), 502-8; Prigent (2010a); Prigent (2006); Prigent (2010b); Laiou and Morrisson (2007), 86.

53 Cosentino (2013a), 65.

54 Horden and Purcell (2000), 54-9.

55 Kennedy (2007b), 67.

56 Horden and Purcell (2000); McCormick (2001); Wickham (2005); Haldon (1990) and Haldon (2016).

57 Howard-Johnston (2010); Brubaker and Haldon (2007); Borrut (2011); Robinson (2003).

58 On the history of the Cypriot autocephalic church, see Mitziadis (2005).

59 Cosentino (2013a); Wickham (2005), 626 ff.

60 Rautman (2005); Papacostas (2013).

61 Wickham (2009), 256-97.

62 Wickham (2005), 12. 


\section{Seeing the unseen}

\section{A brief overview of Cypriot historiography}

Trying to represent the history of Cyprus as standing on the edge of the two biggest and most complex eastern Mediterranean political systems (the Byzantine and the Umayyad) feels like trying to put together a jigsaw of a blurred picture: the pieces can easily be misread or misplaced. In truth, any attempt to reconstruct a coherent interpretative narrative of a historical period based on objective analysis of both documentary and material sources is at risk of being marred with teleological spins and imbalances. We should admit that early medieval history writing is a continuous fight with the few sources at our disposal as historians try to obtain nuanced accounts from them. ${ }^{1}$ However, this does not mean that sources should be taken at face value, never challenged or regarded as problematic. I will return argument to this in the next chapter. In particular, in Cyprus it seems that the few literary and documentary materials at our disposal for the period under scrutiny (histories, letters, and saints' lives) have been used to sketch rather simplified historical narratives. According to one of them, for instance, Cyprus was a bulwark of Iconoclasm and Orthodoxy in a period when even the capital itself was gripped by Iconoclastic fever. ${ }^{2}$ This picture, as will be seen, has been sketched based upon martyrological topoi and fictional narratives and obviously enhanced by the archaeological attention devoted to ecclesiastical buildings. ${ }^{3}$ Until recently, most of the published surveys and excavations have, in fact, focused on early Christian basilicas or the small churches that later replaced them. ${ }^{4}$

This interpretation forces us to consider a multilayered analytical challenge. First is the fact that Cypriot historiography has been influenced by the colonial "binary model":

I am not saying that colonial scholars [like Jeffreys and Megaw] conflated the Byzantine empire with the British Empire, [nevertheless] the binary opposition between imperial/provincial adopted in the twentieth century ... rejected reality and influenced how much medieval archaeology and history was interpreted. ${ }^{5}$

This, of course, comes as no surprise if we consider, for instance, that Byzantine (and Islamic) Sicily suffered a similar fate. ${ }^{6}$ The history of that 
island has often been interpreted with a colonial penchant: the local population supposedly opposed the Byzantine rule as a yoke imposed by a distant ruler, in the same way the "Italians" opposed the Bourbonic and Austro-Hungarian domination during the Risorgimento. This led to the proposal of a preconceived model of development for Byzantine Sicily that built upon the dearth of literary evidence and the impossibility of proposing an alternate discourse based on archaeology, which until few decades ago was completely underdeveloped. As a result, Sicily became the alternative to exarchal Italy and the bulwark of a peripheral, anti-Iconoclastic, and semi-independent socio-political entity with a peculiar identity ${ }^{7}$ - a picture that bears some similarities with the idea of a self-sufficient and fully orthodox province sketched above. In truth, Sicily (like Cyprus) was never marginal to the Byzantine Empire and could seldom be regarded as having developed along independent socio-political and religious lines. $^{8}$

The second challenge, partially related to the previous issue, has to do with the extraordinary flourishing of Christian literature in the seventh century as effectively studied by Claudia Rapp. ${ }^{9}$ The remarkable hagiographical production of the likes of Leontios of Neapolis or John Moscos has been attributed to the tranquillity and prosperity of Cypriot Late Antiquity and interpreted as stemming from the preeminent socio-political roles played by the Cypriot archbishop and bishops on the island and the construction of a regional identity. In Rapp's words:

It is remarkable that when our hagiographers focus their lens on saints who lived/were buried in Cyprus, these were exclusively bishops. This facilitates the creation of a net of episcopal sanctity and holy sites associated with their cities and it is further confirmation of strong regional identity of Cyprus and its church. ${ }^{10}$

This identity was embodied by urban patronage monopolized by local clergy and the development of Cypriot architectural styles, building typologies, and material culture. ${ }^{11}$ However, as Tassos Papacostas has recently showed, we must be really careful when dealing with the supposed peculiarity of Cypriot building techniques, architectural designs, the saints' cults, and their use. This not to diminish the importance of contemporary perceptions, but to avoid falling into the trap of using "players and events not to represent the course of history but the domain of current concerns and the depersonalized archetypes of popular writing". ${ }^{12}$ This potential problem is exemplified in the religious structures erected on the Troodos Massif (although built from the tenth century on), where there never existed a proper architectural tradition peculiar to Cyprus. ${ }^{13}$ On the other hand, one should consider the importance of saints' cults in a diachronic manner to investigate the development of rural and urban settlements well into the eighth and ninth centuries. ${ }^{14}$

This leads us to a third analytical challenge, which partially encapsulates the previous two: confirmation bias. Confirmation bias is a phenomenon 
wherein researchers assign more weight to evidence that confirms their hypothesis and ignore or undervalue evidence that could disprove their hypothesis. ${ }^{15}$ Scholars can never fully alienate themselves from the socio-political and socioeconomic concerns in which their work is embedded. ${ }^{16}$ In this sense, one can only wonder if the postcolonial period and the creation of an independent Cyprus in the 1960s might have lead some scholars to read into the so-called Dark Ages a metanarrative more in tune with the new political and ecclesiastical status quo. ${ }^{17}$ Consider also the role of archaeology in the construction of this interpretation of Cyprus as a fully orthodox, semi-independent province with the local archbishop at its head, for it is exactly in this period that Karageorghis, Dikigoropoulos, and Papageorghiou started excavating large early Christian basilicas as well as other important urban and rural sites. ${ }^{18}$ We must acknowledge that confirmation bias can affect archaeological interpretation. The most obvious and problematic factor when examining the fate of Cyprus in the passage from Late Antiquity to the early Middle Ages, is the clear imbalance caused by the lack of excavation in the northern half of the island due to the peculiar political situation in modern Cyprus. ${ }^{19}$ Moreover, the socalled Cypriot divide after 1974 has become a real obstacle to a proper and unbiased use of archaeology and material culture.

In other words, rather than recognizing the fact that almost one-third of the island (including the capital, Salamis-Constantia, other crucial urban centres like Soloi or Kyrenia, the fortifications on the Pentadaktylos range, and the numerous eighth-century churches in the Karpas Peninsula) has escaped proper archaeological excavation for the last forty years, scholars have often preferred to ignore this black hole and use the available material evidence (yielded by excavation of sites located in the Republic of Cyprus) to bolster a paradigm of decline and depression. A recent edited volume on the of uses and interpretations of times of crises in archaeology has urged us to overcome the temptation to simplistically label as decline what amounts to (sometimes radical) changes in the archaeological records. ${ }^{20}$ This analytical approach, paired with a reassessment of past excavations (as well as current, more stratigraphically aware archaeology), has led to the proposal of a rather different reading of long-standing historiographical problems like the transformations of Roman towns in Christian and Muslim Spain or the supposed catastrophic and almost complete depopulation of regions like Noricum from the sixth to the ninth century. ${ }^{21}$ The latter example is particularly relevant here, for it encourages us to reconsider the long-standing paradigm adopted by early medieval archaeologists that certain types of material culture are markers of ethnic identity. This had allowed Barbara Hausmair to see through the "invisibility" of the Late Antique and early medieval population in the archaeology of Noricum Ripense as owing to our inability to interpret and identify material culture and evidence of settlement patterns. ${ }^{22}$

Other scholars, like Vionis, have also warned against the temptation of labelling the archaeological record by simply equating style with identity and meaning (i.e., catastrophe or decline), in particular when it comes to pottery. 
Rather than regarding material culture as one possible form of communication or one of the many ways of expressing identity, handmade pottery and coarse wares have sometimes been hastily interpreted as indicators of catastrophic disruptions in some areas of the Aegean caused by Slavic invasions. ${ }^{23}$ Indeed, in the case of Greece, recent surveys and analytical reassessment of ceramics has led to the questioning of the historiographical myth of an overwhelming Slavic invasion. For a number of sites in the Peloponnese (Boeotia) and eastern Greece, scholars now propose a peaceful integration of the local population with the "invaders", creating Slavo-Hellenic communities extending beyond hilltop refuge settlements. ${ }^{24}$

But in Cyprus, archaeology has not yet fully come to terms with the issues of crisis and decline. For instance, there is an overwhelming tendency to date any destruction layer to the Arab raids even when there is no evidence supporting this conclusion. The fates of urban sites like Salamis-Constantia have been pictured along these lines, as when Karageorghis, for instance, concluded:

The Arab invasions put an end to the ancient life of Salamis [because] traces of fire, which destroyed the city, are still visible on the sandstone surface of the walls of public buildings, and in the thick layers of ashes which are mixed with fallen debris throughout the city site. ${ }^{25}$

No explanation is provided to justify the real date of this authentic "stratigraphy of a tragedy". On a different note, by re-examining the numismatic evidence from Paphos, Metcalf has instead stressed the need for better publication and interpretation of coin finds, which might allow us to overcome the idea that a dearth of coins heralds abrupt curtailment of economic activity and urban life in Cyprus during the eighth century. ${ }^{26}$

When the Arabs are not being held responsible for the disaster, the end of the urban life is linked to the notorious episode referred to by Theophanes the Confessor concerning the transplantation of the population to Nea Justinianoupolis in $691 .^{27}$ Although the real extent of such a migration has been thoroughly discussed, scholars like Dimitri Chrystou do not hesitate to associate the terminus post quem for the inhabitation of cities like Amathos with the displacement of Cypriot population. ${ }^{28}$ Again it seems that, as in a detective story, archaeologists are eager to identify the culprit of a disaster that must have hit the city. In the process, they often leave evidence belonging to other parts of the city aside and dwell upon the results of the surveys conducted on a single ecclesiastical building located in the upper part of the city: the so-called Acropolitan Basilica. ${ }^{29}$ In fact, Rautman has recently emphasized the importance of recognizing ceramics dated to the eighth and ninth centuries as essential diagnostic material pointing to the vitality of Amathos as a local trade centre in the late seventh and early eighth century. ${ }^{30}$

We can also see that Cypriot historiography is sometimes under the spell of contemporary politics. As I have already stated elsewhere, ${ }^{31}$ many scholars 


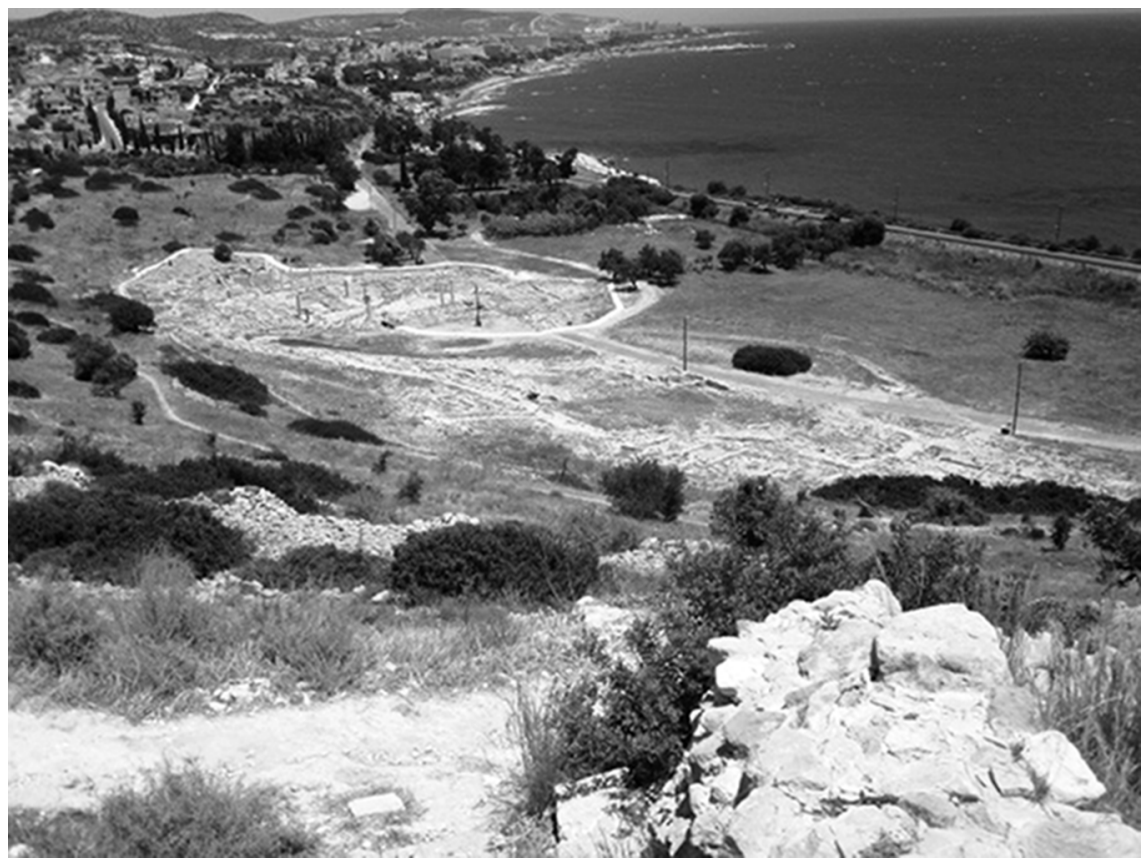

Figure 2.1 Amathos: Agora as seen from the Acropolis

have written about the seventh and eighth centuries with current political events in mind, resulting in cumbersome theories about an island divided between the Arabs and the Byzantines. Metcalf, for instance, has proposed the existence of an internal frontier separating the northern Byzantine and the southern Arab halves of the island. ${ }^{32}$ This hypothesis is supported only by an analysis of a distribution map of coins and lead seals dated to the period 700965. In fact, Vivien Prigent has recently exposed this theory as based almost exclusively on the presence of seals of kleisourarchoi, that is of officials responsible for frontier districts. ${ }^{33}$ Metcalf himself has recently revisited his former assertions in light of underreported and potentially more plentiful finds that might be identified in the Turkish-occupied north. ${ }^{34}$

Proponents of a partition include Arthur Megaw and Costas Kyrris. The former takes for granted that seventh- to ninth-century Paphos should remind us of modern Nicosia because it boasted two separate fortified settlements one inhabited by the Arabs and the other by the Greeks - with no evidence other than an unwieldy interpretation of one Arabic inscription and an early tenth-century passage from John Cameniates. ${ }^{35}$ Kyrris seems to regard the post-1974 situation as tantamount to that supposedly characterizing the island in the aftermath of the Arab raids (i.e., post-654). By relying on a rather flimsy interpretation of bronze coin circulation and an unquestioning acceptance of the passages of few Arabic literary sources, Kyrris asserts that the Arabs imposed a military regime on part of the island, leading to mutual 
transplantations of populations imposed by both the Byzantines (the episode of Nea Justinianoupolis) and the Umayyads (Cypriots transplanted to Syria in the late seventh century). According to Kyrris, the transfer of the local population (anachronistically called "Greek-Cypriots") should be seen as a

passage from an idea of territorial rights to the rights of population and would point to the recognition of the sovereignty of the Arabs on half of the local population but not on the territory. ${ }^{36}$

In recent years, however, a more balanced historiography has gained ground as scholars like Athanasios Papageorghiou, Tassos Papacostas, Vassilis Christides, and Charles Stewart, among others, have tried to propose a different line of investigation for dealing with the history of Cyprus in the early Middle Ages. In particular, Papageorghiou, while reaffirming the role played by Cyprus as an outpost of the iconophile party, also acknowledges that the island experienced real continuity of urban and (partially) rural life until the mid-eighth century. ${ }^{37}$ Even if Papageorghiou's analysis sometimes falls in line with a methodological approach based on ecclesiastical literary sources and the results of religious building excavations, he nevertheless suggests an alternative approach more open to the contributions of Byzantine archaeology than that of the previous generations of scholars, including Kyrris, Megaw, and Costas Chrysos. ${ }^{38}$ Moreover, Papageorghiou recently published a detailed catalogue of the religious buildings located in the Turkish-occupied part of Cyprus, bringing to scholarly attention the problem of the "unseen" and reminding us of the importance of evidence that remains outside the reach of archaeological and scientific examination. ${ }^{39}$

The importance of diverse points of view has been further developed by Papacostas who, in his unfortunately still unpublished doctoral dissertation Byzantine Cyprus, proposes a detailed survey of the different types of available archaeological evidence - from rural surveys to urban excavations, from coins to seals, from ceramic to glass - to show that urban life and economy did not change much until the end of eighth century. ${ }^{40}$ Although Papacostas wrote in 1999 , it is possible to see in both his critique of the supposed ruinous impact of the Arab invasions and his effort in searching for comparative material an anticipation of Walmsley's idea of a smooth transition. Papacostas admits that evidence of continuity has been overlooked in Cyprus, as continuous building activities, Umayyad coins, lead seals, and inscriptions allow one to conclude that the

mid seventh century was not the end [but] a period of transformation: a relocation of rural and urban sites and change of functions of some [public] buildings taken over by domestic or agricultural installations. ${ }^{41}$

Although Papacostas did not have the benefit of a revised analysis of ceramic evidence (of the kind proposed by Ian Randall, Marcus Rautman, Pamela 
Armstrong, and Joanita Vroom almost ten years later ${ }^{42}$ ) or the above-mentioned archaeological assessments produced by Walmsley for the Levant or Cosentino and Zanini for the Byzantine islands, he nevertheless managed to propose a sketchy but fascinating comparison between what happened in Cyprus and in the Near East in terms of settlement patterns and the fates of urban sites. In his opinion, Cyprus has more in common with Syria, Palestine, and Egypt than with areas that stayed under Byzantine sway. ${ }^{43}$ Although no single contribution can be regarded as a definitive turning point in the historiography of early medieval Cyprus, Papacostas's volume provides valuable insights into the diversity of local material culture and the changes that occurred in it, while at the same time introducing the reader to the methodological challenges of different types of sources. This approach has been further developed in later contributions to the field, particularly in recent articles focusing on the origins and development of Nicosia in the Byzantine period. ${ }^{44}$ In analysing the rising of the city as an administrative and ecclesiastical capital, he chose not to compound the role of Arab raids as responsible for the sudden disappearance of the coastal sites but rather to analyse the economic developments on the islands as framed by the economic reorientation of the eastern Mediterranean along regional and subregional markets. ${ }^{45}$

Echoes of his conclusions can be found, for instance, in two recent articles written by Myrto Veikou. Veikou weaves the research on seventh- to ninthcentury Cyprus into larger issues concerning insularity and "islandness" (the sum of representations and perceptions by islanders of the structure of their territory), the scale of landscape settlements, and the interaction between spatial and socioeconomic factors, referring particularly to harbours like SalamisConstantia and Paphos. ${ }^{46}$ The latter in particular emerge as "gateway communities" characterized by their developing and changing roles along maritime networks. This allows Veikou to reorient and contextualize the archaeological narrative of Cyprus after the Arab raids, revealing a period less of catastrophe than of reorganization

within a historical context of settlement by acknowledging different rates of development, a variety of responses to people's needs, and opportunities for economic, social, and cultural growth in different periods of time, moving away from the duality of city-countryside and looking at concentration of population. ${ }^{47}$

Papacostas and Veikou have provided valuable insights into the diversity of local material culture and the changes that occurred in the archaeological record while at the same time introducing the reader to the methodological (and even anthropological) challenges stemming from different types of sources. Indeed, scholars have become aware that the narrative sources for the period, whether first-hand accounts or later compilations, vary in reliability. This newly acquired awareness led Christides, for instance, to stress that we are much in need of a critique of the literary sources (mainly the Christian ones), 
as they exaggerate descriptions of the destitution and persecution happening during the raids. ${ }^{48}$ By the same token, we also have to be careful with Arabic geographers mentioning Cyprus. While they allow us to confirm that the island retained a good degree of prosperity in the so-called "period of neutralization", they are also based heavily upon classical models (such as Orosius's Historia adversos Paganos written in the early fifth century) and were written two or three centuries after the events they describe. ${ }^{49}$ Material evidence has also been handled more carefully in recent years. David Metcalf has produced two very detailed and analytically sound surveys on coins and seals from Cyprus dating from the entire Byzantine period. ${ }^{50}$ Additionally, a (still underway) reassessment of Cypriot ceramics has allowed scholars to shed more light on the production, distribution, and consumption of goods, proving, for instance, that pottery styles produced in the seventh century continued to be made well into the eighth century as well and that wares continued to be imported to the island from the Levant and Constantinople. ${ }^{51}$

In this light, one could regard the contributions written by scholars such as Metcalf and Stewart as ideally picking up from where Andreas Dikigoropoulos left off in his unpublished 1961 dissertation. ${ }^{52}$ Indeed, Dikigoropoulos although searching for the ultimate cause of the eighth- and ninth-century decline - included in his volume not only a comprehensive and detailed analysis of available seals and coins (on which he primarily relied to draw his conclusions) but also an appraisal of both ceramics and architecture. Basing his analysis on his experience as assistant curator of the Museum of the Department of Antiquities and excavator at Salamis-Constantia, Dikigoropoulos admitted that pottery had been as yet totally overlooked. For instance, the plain varieties had often been regarded as less attractive and simply thrown away by archaeologists. ${ }^{53} \mathrm{He}$ also stressed that post-654 building activities were on such a massive scale that they could not have been undertaken by a population twice slaughtered and left to fend for themselves. ${ }^{54}$ Although advocating for the "usual" tripartite chronology (Golden Age, Dark Age, Byzantine Reconquista), an almost full religious and political autonomy of Cyprus from Byzantium for the period 700 to 965 (as indeed he was writing in the wake of the recent independence of the Republic of Cyprus in 1960), and a decline of economic life after Justinian II's reign, Dikigoropoulos was less drastic than many of successors and predecessors. In fact, throughout his book the idea of Cyprus as a unique place in the history of the relationship between Constantinople and Damascus often emerges; a place where an improbable, peculiar but effective coexistence and interaction took place. ${ }^{55}$ In sketching this interaction as not always confrontational, he was in practice (but surely without realizing it, as White's book appeared much later in time) hinting at a possible definition of Cyprus as a real middle ground between the Byzantines and the Umayyads.

It is also important to stress the inspirational role Dikigoropoulos's contribution seems to have played for later historians of Dark Age Cyprus. 
In particular, his awareness of the methodological limitations of the thencurrent analysis of material sources (mainly ceramics and architecture), resonates with the idea, later summarized by McCormick, that "only if we can fully grasp what we cannot see will we finally grasp the meaning of what we observe." 56

Seeing the unseen still remains one of the main problems faced by archaeology of seventh- to ninth-century Cyprus: an absence of coins does not mean an absence of exchange, the end of the traditional Late Antique ceramic types is not tantamount to the sun going down on local pottery industry or foreign imports, the downsizing of ecclesiastical buildings does not imply ruralization or economic impoverishment, and artisanal and commercial functions encroaching onto the classic urban landscape should not be regarded as a sign of decline but rather as evidence of continuous levels of demand from urban oriented elites. ${ }^{57}$

Johannes Koder's analysis of building activities in Makisos (in Cappadocia) overcomes a tripartite chronology similar to that proposed for Cypriot architectural history (fourth- to fifth-century Golden Age, renewal and restoration under Justinian, and any activity after the end of the seventh century). ${ }^{58}$ Koder concludes that "it is almost impossible to prove the end or decline of settlement activity in sites where enough building material or undatable quarry stone was available for use in new periods of building activity". ${ }^{59}$ Moreover, the reliance on perishable material (which can be "seen" only in a sort of archaeological negative, like postholes) had made additions to buildings almost unidentifiable. These challenges were only exacerbated by the first excavators (classical archaeologists), who often removed strata dated to later periods without documenting them. ${ }^{60}$ In Salamis-Constantia, the capital of Cyprus in our period, the surveys conducted at the beginning of the twentieth century removed layers generically labelled as medieval "squatterization" during the excavations at the colossal Bath-Gymnasium complex. A similar fate befell the wooden houses found in the cava of the theatre that were supposedly destroyed during the Arab raids (with no evidence for this date provided). ${ }^{61}$

Seeing the archaeologically unseen not only in practical but also methodological terms is an issue which indirectly lays at the very heart of some of the most relevant contributions focusing on the fate of Cyprus in the seventh and, above all, eighth centuries. First we should consider Charles Stewart's unpublished doctoral dissertation "Domes of Heaven", later reprised in three different publications. ${ }^{62}$ Although still considering the Arab raids a turning point in the history of early medieval Cyprus, Stewart commendably moves away from the stereotypical vision of a deserted island as he demonstrates that a massive building programme focused on churches can be dated to the early to mid-eighth century. In particular, barrel-vaulted churches (characterized by a peculiar layout and a common building technique) were erected in the Karpas Peninsula and Paphos, while in Salamis-Constantia a massive 
renovation was undertaken in the Basilica of Saint Epiphanios and a fortification was erected enclosing part of the Roman city. ${ }^{63}$ But one should be careful when addressing the structural analysis and typological developments of ecclesiastical architecture as the based on the still limited material evidence. Indeed, in most of these examples archaeology cannot be used to bolster an approach that establishes different phases of construction, because most of the churches are located in the occupied northern half of the island. One can also cast some doubts on Stewart's conclusions, such as when he states that the peculiar situation of Cyprus

betwixt the Greeks and the Saracens.... provided conditions that allowed the Cypriots and their president (proedros, the archbishop) to develop a sense of identity apart from the Byzantine empire [and] this perspective motivated the Church to ... experiment in various types of vaulting. ${ }^{64}$

In this passage Stewart seems indebted to Dikigoropoulos, who stated that on-and-off Byzantine sovereignty led to de facto Cypriot independence, hanging upon both religious convictions and imperial policies of the hour and the predominant authority of the local archbishop. ${ }^{65}$ Notwithstanding the above-mentioned caveats, Stewart's approach has the merit of showing that Cyprus retained a degree of economic continuity through its implication that even the diminished urban and rural elites could actively sponsor the reconstruction of local churches. Their wealth continued to circulate and fuelled the demand for artisanal products by employing artisans and even specialized artists in the rebuilding programme (some of the churches, like Agia Varvara in Koroveia or Agia Paraskevi in Yeroskipou, show traces of frescos) ${ }^{66}$ Cyprus also attracted quite a few visitors since many of the churches Stewart mentions were part of the pilgrimage routes leading to the Holy Land, further enabling the island to retain its importance in Mediterranean shipping routes. ${ }^{67}$

Finally, I must mention David Metcalf's Byzantine Cyprus (491-1191). The book is an ambitious struggle to propose a unitary vision of Byzantine rule on Cyprus, incorporating both written and material sources. Metcalf's analysis is based on the sharp contrasting of the three chronological periods already mentioned, as he still regards the Arab raids as the main event shaping the destiny of the island. This is primarily because even though he incorporates archaeology into his narrative and insists upon a critical assessment of the limitations of each of the various strands of evidence, Metcalf gives pride of place to the numismatic evidence. He asserts that

around 700 the everyday use of coinage declined [by a factor] tantamount to a massive collapse of the monetary economy on such a scale that virtually all of the economic specialization and trade was presumably compromised, and with it the economic hierarchy of places that underpinned urban functions, and made city-life viable. ${ }^{68}$ 
Metcalf sets other kinds of material sources (in primis ceramics) against the backdrop of numismatics, drawing a picture of economic decadence and political neutralization - a sort of social "sleepy hollow" on the edge of two empires that also imposed a territorial partition (the northern coast under the Byzantine administration, the southern under Muslim control). As methodological issues concerning coinage will be addressed in the next chapter, let it suffice to say here that Metcalf seems to overlook the fact that circulation of copper coins has more to do with a change of economic occurrences in which exchange and appropriation of surplus took place than with a collapse of economic life. ${ }^{69}$ In other words, one should consider the imperial fiscal restructuring before rushing to any conclusion about the economic situation in an imperial territory.

In this light, one could, for instance, consider the use of barter or instruments of credit, which enabled the maintenance of economic relationships at regional and subregional levels. ${ }^{70}$ Indeed, Alan Walmsley has recently commented upon a stone tablet found in a shop of Jerash listing the accounts of a local shopkeeper:

The tablet proves that the silver dirham was accepted as a standard unit of currency [a role that of silver, reinforced by major eighth-century discovery of dirhams from shops and markets] and that a type of store credit which was known in the later Islamic period was a well-established method of commerce exchange already in the later eighth century. ${ }^{71}$

This not to refute the idea that coins and money are a major indication of economic activity or belittle the decrease in the annual frequency index of copper coins discovered in different areas of the Byzantine Empire for the period 668 to $829,{ }^{72}$ but rather warns against generalizations especially in Cyprus, where we have partially underestimated the importance of the so-called Arab-Byzantine (and also Islamic) coins found on the island as matched by Byzantine emissions. ${ }^{73}$ As will be further discussed, these coins seem to imply the maintenance of political, commercial, and cultural relations between Constantinople and Damascus, for the coins tally with ceramics, inscriptions, and documentary evidence to indicate a coherent and cohesive economic life on the island.

It is, therefore, to this evidence and the challenges arising from their methodologically aware use which we will now turn as these are the basic premises on which a historical study of the fate of Cyprus before and after the advent of the Arabs in the Levant should begin. As we proceed, we should keep in mind not only the historiographical debates summarized above but also - more importantly - the necessity to mould it around the pace and variety of economic and social developments, as they often cannot be accommodated in the conventional narratives of the political, military, and ecclesiastical history of Cyprus. Indeed, these narratives will be tested and compared with material evidence and a detailed critique of the scant documentary and literary sources allowing us to "place" the island within the current debates on the end of the ancient economy and the rise of its medieval successor. 


\section{Notes}

1 Wickham (2009), 12.

2 See Hadjisavvas (2010) and Chrysos (1993). (Partly) contra Metcalf (2009).

3 Zavagno (2011-2012), 140-1. See also Stewart (2014).

4 The latest examples of this trend are the volume edited by Megaw on the Basilica of Kourion (2007) and the unpublished thesis of Papacostas (1999), as well as Stewart's volume on the eighth-century churches of Cyprus (2008). Rural surveys like those of Rautman (1998 and 2003) have privileged the analysis of ecclesiastical buildings. Only the recent publication of the excavations at Polis-Arsinoe (Caraher and Papalexandrou (2012) and Caraher, Moore, Olson, and Papalexandrou (2013)) have broadened archaeological horizons and focused on the secular urban fabric: residential areas and commercial and artisanal workshops.

5 Stewart (2014), 111. Also Davis and Stewart (2014).

6 Nef and Prigent (2006), 12-25.

7 Ibid., 29-31.

8 Cosentino (2013b).

9 Rapp (2014); Rapp (2015).

10 Rapp (2015), 409.

11 Stewart (2014), 119; also Stewart (2016) and Randall (2013), 279-80.

12 Conrad (1996), 181.

13 Papacostas (2013), 189-90.

14 Papacostas (2014), 187.

15 Nickerson (1998).

16 O'Brien (2013), 19.

17 Davis and Stewart (2014), 22.

18 See, for instance, Dikigoropoulos (1961) and Karageorghis's chronicles of archaeological excavations across Cyprus published in Bulletin de Correspondence Hellénique from 1960 to 1969 (BCH 84 (1960), 242-99; BCH 89 (1965), 231-300; BCH 91 (1967), 275-370; BCH 92 (1968), 261-358, and BCH 93 (1969), 431-569); see also the contributions Papageorghiou wrote from 1964 to 1970 in $A B$ and $\mathrm{K} \Sigma$ and Papageorghiou (1985c).

19 On July 15, 1974, Turkish military forces invaded and occupied the northern part of Cyprus (approximately 38 per cent of the island) following a coup d'état approved by the Greek Military Junta and staged by the Cyprus nationalist paramilitary groups called EOKA-B (whose ultimate goal was political annexation with Greece). As a result, the territory and its government (referred to as the Turkish Republic of Northern Cyprus to distinguish it from the internationally recognized Republic of Cyprus in the south) is not recognized as an independent country by any state apart from Turkey (a concise description of the so-called Cypriot issue can be found in Ker-Lindsey (2011) with further bibliography). The presence of the Turkish military in northern Cyprus meant that any archaeological survey or excavation on this part of the island was suddenly suspended and subject to the regulations of UNESCO's Convention for the Protection of Cultural Property in the Event of Armed Conflict, or the Hague Convention of 1954 (prescribing a series of procedures designed to protect cultural properties from accidental destruction when caught between warring parties; see Harpster (2008), 4, 7-8). It is not my intention to dwell on the catastrophic consequences of the invasion and occupation in terms of conservation and preservation of archaeological and cultural heritage (Davis and Stewart (2014), 22; Walsh, Edbury, and Coureas (2012)). I will simply refer the reader to three publications that may provide a better grasp of the status quo and the problems stemming from more than fortyfive years of debate on the matter: Hardy (2011); Şevetoğlu, Tuncel, and Şahoğlu (2015); and Hadjisavvas (2015). 
20 Van der Wilt, Martinez Jiménez, and Petruccioli (2013).

21 Martinez Jiménez (2013); Hausmair (2013).

22 Hausmair (2013), 155-7.

23 A good summary of the status questionis can be found in Curta (2011), 97-134.

24 Vionis (2013a), 112.

25 Karageorghis (1969), 13.

26 Metcalf (2013a), 70-4.

27 Theophanes $(1997,509)$.

28 For Nea Justinianoupolis, see Englezakis (2010); see also Metcalf (2009), 450-5; Stewart (2008), 78-81; Kyrris (1985), 165-6; and Christou (1997).

29 I will return to this in Chapter Five. Here, it suffices to say that although writing in 1961, Dikigoropoulos (1961, 221-2) was much more cautious about the end of city life in Amathos than scholars like Aupert (2003/4) and Chrysos (1993) who, in my opinion, do not fully exploit the material evidence (like seals and ceramics) yielded in different areas of the site. A reappraisal of the archaeological excavations in Amathos has been proposed by Metcalf (2009, 288-91).

30 Rautman (2014), 52.

31 Zavagno (2011-2012), 123-6.

32 Metcalf (2009), 425-34.

33 Prigent (2012), 82.

34 Metcalf (2009), 431; also Metcalf (2013b).

35 Megaw (1988).

36 Kyrris (1997).

37 Papageorghiou (1993).

38 Papageorghiou (1981); Megaw (1986); Kyrris (1997); Chrysos (1993).

39 Papageorghiou (2011).

40 Papacostas (1999), 213-14.

41 Ibid., 210.

42 Armstrong (2006); Armstrong (2009); Vroom (2005); Rautman (2003); Randall (2013).

43 Papacostas (1999), 216.

44 Papacostas (2012).

45 Ibid., 103.

46 Veikou (2015a); Veikou (2015b).

47 Veikou (2015b), 368.

48 Christides (2006), 25.

49 See for instance Sizgorich (2004); also Christides (2006), 5-20.

50 Metcalf (2004); Metcalf (2009), 141-227.

51 Haldon (2012a),104-8.

52 Dikigoropoulos (1961).

53 Stewart (2008), 23 and n. 101; Dikigoropoulos (1961), 323-9.

54 Ibid., 22.

55 See for instance the cumbersome but fascinating theory he set forth to explain the Byzantine siege of Damietta in Egypt in 706 (Dikigoropoulos (1961), 49).

56 McCormick (2012), 97.

57 Haldon (2012a), 4.

58 Koder (2012), 150-1.

59 Ibid.

60 See Carandini (2010).

61 Karageorghis (1963).

62 Stewart (2008); Stewart (2010); Stewart (2014); and Stewart (2016).

63 Stewart (2016), 81-2.

64 Ibid.,86.

65 Dikigoropoulos (1961), 70-86. 
28 A brief overview of Cypriot historiography

66 On the frescos see Farace (2015).

67 Stewart (2010), 182.

68 Metcalf (2009), 36.

69 Haldon (2012a), 112.

70 Ibid.

71 Walmsley (2012), 327.

72 Laiou and Morrisson (2007), 84-9.

73 Zavagno (2011); see on this Metcalf (2013a), 73-4. 


\section{The mousetrap of methodology}

In The Mousetrap, the long-running play by Agatha Christie, a group of people find themselves trapped by snow in a manor, and among them hides a mysterious murderer who has struck twice already. ${ }^{1}$ As soon as it becomes clear that the killer must be member of the group (each of whom carries a secret from their past) a trap is set in which all the characters are sent to different rooms to re-enact one another's testimonies. As in many of Christie's novels, The Mousetrap reveals her use of a classic mystery trope: a murder is committed, multiple suspects are forced to convene together, the detective unfolds their secrets while investigating until a final twist leads to the identification of the killer. Whenever the Mousetrap is staged the audience is asked not to reveal the end of the play so as not to spoil it for future audiences.

More often than not historians (and archaeologists) like to regard themselves as detectives investigating the "crime scenes" of past events, gathering evidence (sources), evaluation its typology (written or material), interrogating sources using diverse methods of analysis and coaxing them to reveal their secrets, and eventually identifying the culprit, or main cause, explaining causalities and correlations of any past event. ${ }^{2}$ One is tempted to label this process as the "Quest for Historical Truth". As Ray Brown and Lawrence Kreiser stress:

Historians, in searching for reality and truth, are interested in documents and evidence - those that are dull and those that are lively, those that tell lies in the guise of truth as well as those that contain truth. ${ }^{3}$

However, this process is made more difficult because one of the historian's tasks is not simply to separate truth from fiction but also, equally importantly, to discover the truth in fiction. Written sources (literary or documentary) for instance

used to be regarded as unproblematic; the statements they made were true or false... This neglects the fact that authors also write in a contemporary environment and for a contemporary audience. How we navigate this epistemological and practical minefield is of crucial importance. ${ }^{4}$ 
It is convenient to think of material sources as an easy way of out of this problem since recovered objects have the potential to act as independent sources of evidence for reconstructing the causative aspects of economic, political, social, and cultural changes. ${ }^{5}$ As in a game of Clue, discovering the weapon and the location of the murder greatly helps the players unmask the author of the crime. Unfortunately, however, more often than not coins, inscriptions, seals, ceramics, buildings, and works of art represent too fragmentary a body of data on which to formulate an independent vision of an event. ${ }^{6}$ Additionally, they all have to be analysed with regard to the cultural, political, and social context in which they were created. This process, as Walmsley has showed for early Islamic Syria, can quickly devalue material records as indicators of change. ${ }^{7}$ Moreover, historians may be guided by prejudices or misconceptions and therefore correlate material evidence with the information related by chronicles and related texts to find the culprit they had in mind from the beginning. ${ }^{8}$

At first sight it seems that this is exactly what happened to many scholars who faced the daunting task of using the many sources at their disposal to interpret the transition of Cyprus from Late Antiquity to the early Middle Ages. More often than not these scholars reveal the

"mousetrap" to their audience well in advance: Cyprus was declining from the seventh century on; all the social, cultural, and economic parameters point to the collapse of urban and rural life; and the victims were the Cypriots who paid their constant loyalty to Byzantium and to the Orthodox Church.

As for the

"killer", as we have already mentioned, all leads point to the Arab invasions (or alternatively to the transplantation of the Cypriots to Nea Justinianoupolis): in the wake of the few available documentary sources, material evidence (coins, seals, or ceramics) has been summoned only to eliminate other possible suspects. ${ }^{9}$

In other words, there is no final twist. It looks like the entire - the fate of Cyprus in the seventh and eighth centuries - develops backwards: from the end to the beginning. The culprit has been caught red-handed and methodology is just called in to confirm the motives, means, and opportunities of the criminals.

How can one rewind the plot and try to avoid the traps of a preconceived use of material and documentary sources? How can one build a different narrative based upon a conscious and careful methodological approach to the broad spectrum of evidence at our disposal? Is it possible to acquit the usual suspects and investigate the matter from a more objective viewpoint? The current chapter will try to answer to these questions in two acts. The first will 
present the reader with some general methodological issues concerning the sources used in the book; the second will sketch an alternative account of the history of the island in the period under scrutiny as based upon a more cautious and conscious use of the wide range of material available.

One should also be fully aware that more detailed presentations of the analytical problems singled out through the use of different material sources have been produced for the period under scrutiny here. Indeed, the volume by John Haldon and Leslie Brubaker on the Iconoclast era presents us with an invaluable summary of annotated sources dated to the seventh to ninth century and prompts a general overview of the archaeological data and a rough guide to the material sources. ${ }^{10}$ In this light, epigraphy, sigillography, numismatics, sculpture, metalwork, textiles, and architecture receive pride of place in the following pages not only because they are usually better understood and studied than, for instance, glass, textiles, or metalwork but also because in the proposed interpretative framework their developments deeply resonate with the economic and social profile of Cyprus in the passage from Late Antiquity to the early Middle Ages. ${ }^{11}$

\section{Act I: General problems of method}

In introducing the main characters, that is the economic parameters (enhanced by the material indicators like ceramics and coins) regarded as the main guides to a rather obscure period characterized by a serious dearth of literary and documentary sources, one can hardly resist the temptation to summon pottery onto the methodological stage. The analysis of ceramics allows us to focus on the lifestyle, cultural habits, and social complexity of the lower strata of society that are seldom mentioned by historical sources. ${ }^{12}$ It also allows us to address the recent debate on whether archaeology aids in deciphering the real nature of times of crisis. ${ }^{13}$ The details of the debate need not be scrutinized here. It suffices to say that when examining a crisis, it is important to take into consideration the capacity for resilience, which often is not evenly distributed across the socioeconomic playing field. As P. Mitchell says:

Let us not fall into the trap of assuming that it is always the poor or the politically disadvantaged who are most susceptible to crises: rather those most removed from subsistence production may be those most exposed to shortfalls in food or disruptions. ${ }^{14}$

As Wickham points out, among the archaeological evidence, which better equips us to answer questions concerning the large and small range of exchange, ceramics is the most useful, both because it is the most common human-made tool found in archaeological excavations and because it can often be fairly precisely sourced based upon style and fabric analysis. Because of pottery we can debate the organization of production, the distance goods were moved, and how much came from where in any period. ${ }^{15}$ Moreover, as 


\section{The mousetrap of methodology}

Ken Dark, Joanita Vroom, Pamela Armstrong, Athanasios Vionis, Enrico Zanini, and Alan Walmsley have pointed out, the study of pottery remains a cornerstone of Middle Eastern and Byzantine archaeology. ${ }^{16}$ In particular, Zanini encourages us to consider pottery as a complex sign system that comes from a distant past and does not permit univocal and constant decoding methods. ${ }^{17}$ In this way - as Randall concludes - ceramics can be used to explore the relationship between people and material culture as they structure the changing social world. ${ }^{18}$

However, Dark also urges us to overcome value judgments, pointing out that material evidence like pottery hardly comes with cultural labels attached and one has to objectively ascribe them to political and cultural groups known from other sources. ${ }^{19}$ Walmsley shows the validity of this conclusion when examining the early Islamic sequence of pottery from the excavations in Syria and Palestine, demonstrating that

the pottery of the eighth century clearly originated in the technologies of the preceding periods, with the changes representing local developments, not a radical break influenced by outside developments. ${ }^{20}$

As will be seen, developments in local pottery production, manufacture technologies, and distribution can lead us to an appreciation of the socioeconomic trajectories of Cyprus as more in tune with those of early Islamic Syria and Palestine. $^{21}$

Together with ceramics, coins are another essential material source, and not only because they are dating tools for establishing absolute chronologies or good indicators of the continuity of artisanal and technological know-how. ${ }^{22}$ Patterns of human movement and communication are mirrored by the pattern of coins. ${ }^{23}$ For instance, Arab-Byzantine and post-reform Islamic coins found in Cyprus can clearly reflect the directions, rhythms, and flow of trade between Islamic and Byzantine territories, as McCormick established for the whole eastern Mediterranean. ${ }^{24}$ However the economic importance of coins and coinage is not limited to their function as means of exchange, for they can offer even more information concerning the fiscal structures and military activity linked to certain political events. ${ }^{25}$

As Laiou and Morrisson stress, the historian is asked to navigate troubled waters as Byzantine coinage was affected by a crisis in the seventh century. At that time, the Byzantine monetary system went through a drastic process of simplification resulting in the eighth- to tenth-century abridged structure based upon one denomination per metal: the gold nomisma, the silver miliaresion, and the copper follis. $^{26}$ This development is associated with a decreasing quantity of coin hoards and stray finds and a real collapse of coin circulation bottoming out in the early ninth century. ${ }^{27}$ However, the persistence of taxation and the sizable cash revenues maintained by the Byzantine government and used to subsidize the administrative, bureaucratic, and military apparatus (the vitality of which is confirmed by sigillographic evidence) explain the 
resilience of monetization, at least in important cities, coastal regions, and islands like Sicily. ${ }^{28}$

However, as Cyprus lay at the edge of two empires, one should also take into account the developments of coinage in the so-called Bilād as-Shām (the Umayyad province of Syria and Palestine), where the monetary economy remained extraordinarily active. ${ }^{29}$ The variety and adaptability shown by coinage circulating in Syria and Palestine in the late seventh and early eighth century is epitomized by the so-called Arab-Byzantine coins - specimens issued by the Arab authorities and local bishops as precious substitutes for Byzantine copper coinage in local and regional markets and heavily inspired by or dependent on (in terms of iconography and metrology) Byzantine coins. ${ }^{30}$ Although specimens of this type have been found in Cyprus (and many more have been incorrectly identified in excavations of Salamis-Constantia and Paphos), this should not lead us to conclude that the whole Levant retained high level of monetization. ${ }^{31}$ Indeed, pockets of demonetized or weakened monetary economy existed in Bilād as-Shām outside the main towns. ${ }^{32}$ By the same token, as these pre-reform transitional coins were circulating in Cyprus (to be replaced later by the post-692 reformed, aniconic coins in gold, silver, and copper characterized by inscriptions celebrating Allah and the Prophet) they could reveal levels of cultural empathy and economic links that transcended the supposedly impermeable divide between the Arabs and the Byzantines. $^{33}$

Seals are an excellent complement to the information provided by the previously mentioned material sources. Indeed, lead seals are one of the most important sources for understanding the Byzantine fiscal and bureaucratic machinery, ${ }^{34}$ especially because coinage and pottery do not provide us with any information concerning the developments of provincial administration. ${ }^{35}$ Seals (particularly those cast onto lead blanks) were used to validate documents or to give legal power to the acts to which they were attached, and they were used by both civil servants and ecclesiastical authorities. ${ }^{36}$ On each specimen one might find the owner's titles and offices, although apart from bishops or archbishops we can seldom match a written record and a seal of the same individual. ${ }^{37}$ Nevertheless, as seals are always found within a short distance of the destination of the documents to which they were attached, they help historians reconstruct historical maps of the correspondence between the local, provincial, and central authorities, pointing to the persistence of government administration, the role of military commanders (like the archontes or the strategoi), and the importance of leading local elites and ecclesiastical authorities. ${ }^{38}$ Analysis of lead seals demonstrates that all these groups maintained regular links with the capital (or even capitals, if we consider the few Islamic seals recovered on Cyprus), for "the ownership of a lead seal is only half of the story: the range of persons the owner corresponded with is the other half". ${ }^{39}$ Finally, as Haldon has pointed out, the importance of a peculiar type of lead seal (those belonging to the kommerkiarioi) should also be taken into consideration: 
From 660 to 731 C.E. the activities of the genikoi kommerkiarioi and the associated provincial apothekoi (state warehouse or granary) ... were connected with a range of duties related to fiscal administration and supplying of Constantinople and the imperial Army [whereas] basilica kommerkia [were] associated with specific location at which import-export of goods could be supervised. ${ }^{40}$

Both the seals belonging to kommerkiaroi and those mentioning the archontes, as found on Cyprus as well as on other islands like Crete, Sicily, Malta, and the Balearics, will be compared to trace the transformations of the new institutional forms of governance and the rather vital commercial role played by the Byzantine insular system well into the eighth century. ${ }^{41}$

Architecture and buildings are the last piece of evidence on which we will rely to draw the picture of Cyprus in the transition from Late Antiquity to the early Middle Ages. The foundation or restoration of edifices brings about numerous social, religious, cultural, and economic issues, which are deeply enmeshed with the changes experienced by the urban fabric and urban settlements. Archaeology of Late Antique and early medieval Cyprus has primarily given pride of place to religious buildings. This is partially owed to the generous patronage and wealth of the local citizens, bishops, and archbishops in building a large score of early Christian wooden-roof basilicas dated from the early fifth to the late sixth century, whose floors were lavishly covered in mosaics or opus sectile. ${ }^{42}$

In light of this, I propose a different way of looking at buildings (and in particular ecclesiastical ones) rather less concerned with their artistic merits, architectural decoration, or ichnographic characteristics. This is only partially because the churches fall outside the chronological focus of this book, for many of the early Christian basilicas were continuously occupied and refurbished (although in a much less pretentious style and size) in the seventh, eighth, and ninth centuries. ${ }^{43}$ Instead, it has more to do with a social and economic analytical approach, which gives importance to the role that elites (both secular and ecclesiastical) played in patronizing and supporting the building of the fifth- and sixth-century Cypriot basilicas.

Two brief examples will be useful here. As in other islands, like the Balearics and Malta for instance, Christian archaeology on Cyprus needs to reorient its focus and analyse the role of the church in the strategies of land control, economic activities and regional and subregional settlement patterns. ${ }^{44}$ This echoes the concept of "archaeology of power", defined as the series of archaeological markers from which the structure and the actions of the elites in power can be understood and seen. ${ }^{45}$ The recent application of this analytical approach to seventh-century Spain has allowed a better grasp of the sociopolitical, cultural, and economic adaptive strategies used by the urban and rural elites to overcome the Visigothic crisis. The transformative process there focused on the civic mobilization of aristocratic families and their unification under a new religion and monarch in charge of a better organized and more 
centralized state. ${ }^{46}$ Archaeological evidence, therefore, mirrors this complex picture and shows a flourishing of new urban patronage endeavours, the creation of new networks of villages (replacing the old villas) with a degree of social hierarchy reaching its peak in the eighth century, or, finally, the construction of many new religious buildings as clear investment outlets for the wealth of rural elites. ${ }^{47}$

A second example brings us to the Adriatic and in particular to Venice, where an expansion of church building activities is clearly documented for the eighth and ninth centuries. Indeed, McCormick has showed us that

overall church building is the best documented type of construction. It is also the most monumental and expensive ... such sudden and massive investment in building churches may indicate a growing population. It surely testifies to a surge in wealth. ${ }^{48}$

With this in mind one can imagine a similar surge in wealth for fifth- to sixthcentury Cyprus as reflecting parallel and independent evidence of the kind McCormick recouped for Venice (silken textiles, Byzantine artworks and coins, as well as documents showing travellers, goods, and the ships that carried them). Hence, one could also side with Peter Brown, that in order to understand the complex relationship between local elites and the Christian church one should look beyond the stereotypical idea of a church becoming inevitably more and more powerful to the idea that a church might instead become more and more "aristocratized" ${ }^{49}$ This interpretative framework could be further bolstered by a comparison with the ecclesiastical edifices built in sixth- and seventh-century Gaul and Italy. These were not only smaller than the basilicas that preceded them, but also less elaborate in terms of plan and built structure, stemming from a generally slowing pace of building campaigns both in cities and the countryside. However, rather than signs of regression, these smaller churches were the result of changes in the scale and geography of land-based wealth, for they reflected the rise of the managerial bishops who replaced aristocrats as effective wardens of the church's wealth. ${ }^{50}$ In the same vein, Cyprus experienced the abandonment of the basilica type in favour of a more compact and serviceable kind of church (certainly less rich than the mosaic laden churches of Gaul and Italy). As already mentioned, from the late seventh century and well into the eighth and ninth centuries both urban and rural settlements witnessed the erection of barrel-vaulted and multi-dome churches in which artists seem to have embraced their tasks with less skill and less thriftiness. ${ }^{51}$

As I will return to the last issue in the chapters that follow, we should conclude this section by noting important documentary and literary sources, lest they appear to have been ignored or regarded as only a corollary to material evidence. That said, when dealing with written sources the reader can be easily put off by the intrinsic problems related to their critique. ${ }^{52}$ Indeed, one should stress, as have Brubaker and Haldon, that 
authorial intention, assumptions, and agendas, as well as the formal framework within which the historian or chronicle worked - consciously or not - played an equally crucial role in determining how the material employed by the writer interacted with the broader cultural context. ${ }^{53}$

Moreover, we have to consider that narratives of events could morph into complex typological varieties: chronicles, hagiographies, acts of ecclesiastical councils, letters, official and unofficial documents, and geographical works. These typologies have been deeply analysed and meticulously presented, again by Brubaker and Haldon, with particular regard to the Iconoclastic period, for they are saddled with different ideological and methodological issues:

Using the historical works of the period, in consequence, brings with it a
number of difficulties, of which the historian must be aware. And these
problems are not simply of the order described so far: technical problems,
for example, with chronology - dates for events, calculations of eras, and
lengths of reigns - are common. Repetition and reuse of material, especially
well-known stories, is also not unusual, with the result that the reader
should never take the account of the text for granted, but rather seek to
establish the context of the information given, if there are any parallel
traditions or sources of information, whether they are historiographical in
nature or not. ${ }^{54}$

There is no space here to delve into the interpretative problems related to these categories of writing, although the reader should be presented - at least briefly - with some of the issues at stake when dealing with the written sources that will be used to draw the history of Cyprus in the period under scrutiny. For instance, the hagiographies of the seventh and eighth centuries have only recently undergone a scrupulous (although still limited) critical assessment, which has argued convincingly how saints were selectively chosen to become the main characters of texts produced with specific agendas. ${ }^{55}$ Moreover, it has been unequivocally concluded that hagiographies also mirrored popular and unofficial views and attitudes clearly informed by contemporary ideological programs often dismissed by the mainstream historiography. ${ }^{56}$ With this in mind, one should nevertheless try to list all the available sources and briefly contextualize them before using their information palette to colour the picture of Cyprus between the seventh and the early ninth century.

In this light and in tune with a coda to this chapter, three further issues should be considered. The first concerns the range of languages in which the various sources have been written ${ }^{57}$ Syriac history writing and Arabic texts help us to confirm or question tradition as set forth by Byzantine narratives written in Greek. ${ }^{58}$ The significance of this variety goes beyond the obvious vantage point offered by their interrelation in order to face the problems of contradiction and (deliberate) bias prompted by the reading of a particular source. Indeed, it also allows us to grapple with the complexity of the transmission of 
historical information. For instance, the eighth-century Byzantine chronicler Theophanes had access to highly detailed information on events happening in Syria and Palestine until 780s (relying on a partially lost chronicle in Syriac), but he knew nothing about the region after that time. ${ }^{59}$ In other words, we should question what any source can teach us, since not all questions can be answered by it. ${ }^{60}$

The above-mentioned linguistic variety inevitably tallies with a second complex issue: the methodological critique of the Arab sources (as effectively summarized by Howard and Johnston, Kennedy, and Mansouri, among others). ${ }^{61}$ In particular, Kennedy argues:

Early Islamic historiography presents an unique and baffling problem because the accounts that we have are very full and detailed, frequently including verbatim eyewitness reports, but there is a significant time lag between the described events and the time when we know they were written (i.e., in the decades after the Abbasid revolution of 750). ${ }^{62}$

Early Muslim authors dealt with the chronological décalage and the consequent problems of authenticity and reliability through the practice of systematically quoting their sources. This stratagem comes under the heading isnād and consists of a methodical citation of those narrators who have previously mentioned the fact reported by the current author, the quest for authenticity and legitimization ending only with the original (supposedly) eye-witness. ${ }^{63}$ As will be seen, until few years ago the problem of the transmitters wasn't considered by those scholars writing about the relationship between the Arabs and the Byzantines in Cyprus. ${ }^{64}$

In fact, in the last decade Mansouri, Christides, and Beihammer have tried to contextualize the contribution of the Arabic sources with special regard to the 686-88 treaty between the Umayyads and the Byzantines and the subsequent legal status of the island. ${ }^{65}$ Rather than considering the island to have been neglected by contemporary witnesses, they have instead stressed its position at the junction of two imperial spheres of influence and politically overlooked by both (as an independent state from the Arab perspective and as a province with self-sufficient elites from the Byzantine). This conceptualization frames the narration of the Cypriot middle ground to which I will return later. Indeed, this opens the door to the third and final issue, centred upon the articulation of early Muslim narratives, which for Sizgorich are central to the creation of communal identity across a cultural borderland. ${ }^{66}$ Sizgorich's definition of borderland echoes that of middle ground: borderlands often housed politically, socially, and culturally hybrid entities in which different influences coalesce. Hybrids in turn incorporate and embody the tensions of dichotomies confined to a single textual entity. With this in mind one could even interpret the scarcity of documentary sources mentioning Cyprus from the seventh to the ninth century as the result neither of the neutralization of the island at the edge of the boundaries defining the medieval Eastern Roman 
identity nor of its marginal role vis-à-vis the great political-military events taking place in the Byzantine heartland. ${ }^{67}$

In a sense, therefore, what Byzantine historiography has often downplayed as simply the political originality of islands with representatives of both communities living side by side could in fact be the very foundation of the few narratives we possess concerning the daily economic, social, and cultural life in Cyprus. ${ }^{68}$ As the two sides tried to encompass and define the rather fluid social and political status of the island by using the usual categories and labels (for the Byzantines, institutions like the theme or titles like strategos and archontes, for the Arabs, the legal status and the local inhabitants) they were uneasy and so they preferred to gloss over this state of affairs in narratives concerning the island. ${ }^{69}$ To external observers, for instance, the commonality between Muslims and Christians was totally unfathomable and, to an extent, uncomfortable, as witnessed by the famous episode reported in the tenth-century life of Saint Constantine the Jew:

While he [the Saint] was performing prayer in one of the churches of the island the Ismailite Saracens came upon the sanctuary, for they had part in the government of Cyprus. This prompted the blessed man quickly to leave the island. ${ }^{70}$

Constantine was a pilgrim from Anatolia and therefore one should excuse his inability to fully grasp the creative arrangement of a social space and the establishment of social relationships on the island. ${ }^{71}$ It is indeed this very creative process which should be regarded as the compass to navigate the methodological and epistemological field of the narratives regarding Cyprus in the passage from Late Antiquity to the early Middle Ages, while at the same time realizing that the social relationships these narratives validate also reflect the functional movement of goods and people witnessed by archaeology. ${ }^{72}$

\section{Act II: Literary and material sources for early medieval Cyprus}

As profusely mentioned in the previous pages, the historiography of Cyprus in the passage from Late Antiquity to the early Middle Ages has often relied on catastrophe to explain the economic, social, and political "decline" of the island vis-à-vis the dramatic downsizing and reorganization of the Roman Empire in the eastern Mediterranean resulting from the break of the Egyptian tax spine, the loss of the wealthiest southeastern provinces, and the subsequent decline in fiscal resources, population, and trade. ${ }^{73}$ However, this analytical framework should be exhaustively reassessed in light of new and more up-to-date methodological analysis of both the narratives and the archaeology concerning the island in the period under consideration. The following section, therefore, will present the reader with a brief but detailed list of the sources that will be used in the following chapters to sketch a different interpretation the island's fate. We will move away from the more general methodological issues sketched 
above to focus on the archaeological, material, and literary evidence concerning Cyprus. Through a more cautious methodologically aware and comparative approach to the sources we will fully grasp the similarities, in terms of political structures and, above all, material culture, with the "smooth transition" experienced in contemporary Syria and Palestine. We will also see similar developments to those on other islands of the Byzantine Mediterranean, prompting the creation of a different historiographical overview of Cyprus in the period from Late Antiquity to the early Middle Ages. ${ }^{74}$

$* * * * * * * * *$

Coins comprise one of the main bodies of evidence scholars from all different walks of academic life have used to analyse and discuss the fate of Cyprus from the late sixth to the early ninth century ${ }^{75}$ Dikigoropoulos, for instance, interpreted numismatic evidence as providing further proof of the catastrophic flip that brought about the virtual disappearance of monetary economy. ${ }^{76}$ Indeed, scholars such as Pitsillides, Metcalf, and Rautman, ${ }^{77}$ among others, followed in Dikigoropoulos's footsteps by overemphasizing the scarcity of coins circulating on the island in the eighth and ninth centuries and claiming that the lack of any sign of recovery for the next four centuries was peculiar to Cyprus. ${ }^{78}$ In other words, if monetary circulation was really intense during the reign of Heraclius and Constans II, then the impact of the Arab raids, tax division, and eventually the transfer of part of the Cypriot population to Nea Justinianoupolis on the Hellespont in 691 caused a dramatic diminution of coin finds on the island dating from the 680s onwards, heralding the irreversible decline of the Cypriot economy for almost three centuries. ${ }^{79}$

In Metcalf's words:

The major contribution that coin finds can make to our understanding of Byzantine Cyprus is through establishing historical trends in the quantities of coins accidently lost. By far the most abundant are losses of copper coins of Heraclius and Constans II.... Some of the gold hoards are from the time of the Arab invasions of 649 and 653 [or were] brought to Cyprus in $641-42$ by the refugees from Alexandria.... After the departure of Constans II to the West in 661/2 the supplies of [copper] coinage reaching Cyprus from Constantinople declined drastically or - we might say - during the reign of Constantine IV they ceased. Between the late seventh and early eighth century, the accidental loss-rate fell a hundredfold or more in the countryside. This statistic doubtless represents the collapse of money economy in the countryside. ${ }^{80}$

At first glance, Metcalf's conclusions seem indisputable and even confirmed by Morrisson, when analysing the general collapse of coin finds as result of the increasing fragmentation of the Byzantine-Mediterranean system. ${ }^{81}$ However, one must note that for the French numismatist the decline in monetary 


\section{0}

The mousetrap of methodology

circulation not only preceded the Arab invasions, but demonetization was uneven across the Empire. Sicily, for instance, experienced intense circulation from 668 to 811 nearly comparable to that of the Justinianic period, while distribution patterns of coins minted in Syracuse from the seventh to the ninth century reveal a network spreading across the Mediterranean and the Black Sea from the Balearic Islands to Cyprus and from Cherson to Malta. ${ }^{82}$

The comparison with Sicily is particularly relevant when addressing the numismatic evidence in Cyprus. ${ }^{83}$ On the one hand, one should stress here that archaeology has made great progress in Sicily during the last four decades, revealing a rather different picture than the one previously drawn by historiography. ${ }^{84}$ Sicily had a strong fiscal link with Constantinople; after the loss of Egypt, it became the main source of grain for the Byzantine capital, while at the same time retaining commercial relations with the urban centres in southern Italy. ${ }^{85}$ Although archaeological evidence remains sketchy, one can only imagine the results of an improvement in Cypriot archaeology similar to that experienced on Sicily (if, for instance, urban sites like Salamis-Constantia or Soloi were completely open to archaeological investigation).$^{86}$ On the other hand, the example of Sicily helps us adjust the focus of the numismatic research on Late Antique and early medieval Cyprus, because archaeologists often use coins only as dating tools for creating absolute chronologies. ${ }^{87}$ One should not gloss over the fact that the presence (or absence, in the case of Cyprus) of coins from archaeological layers can only be understood if related to the methods of and reasons for their issuance by the government. ${ }^{88}$ As Prigent has shown for Sicily, the change in the monetary circulation owed to the revised fiscal needs of the state. Indeed, the fiscal reform sponsored by Constantine VI introduced a four-time heavier follis because the needs of the fiscal system were simply not satisfied anymore by massive emissions of coins previously used to to inject cash to be spent by the contributors. ${ }^{89}$

The bronze petty coinage found in Cyprus also reflects the political and military vicissitudes of the island and probable internal restructuring of tax collection (i.e., the way the army was paid and supplied), while also reflecting the nature of commercial and exchange relations. ${ }^{90}$ The abundance of copper coins (found in both stray finds and hoards) during the reigns of Heraclius and Constans II (together with the countermarked coins dated to Constantine IV) stemmed from the military relevance of the island vis-à-vis the Persian and the Arab occupation of the Levant, the role it played in the Byzantine fiscal network, and its importance as a strategic hub along the interregional shipping routes (especially those linking Syria-Palestine and Egypt with Constantinople). ${ }^{91}$ By the same token, however, the decline in coins minted post-700 was not tantamount to the collapse of the Cypriot economy and prosperity. ${ }^{92}$ Consider Crete, where, in the capital Gortyn, bronze coins continued to circulate into the eighth century with a caesura only from 715 on. ${ }^{93}$

Moreover, on Cyprus (as well as on Crete) older coins remained in use. ${ }^{94}$ This is evidenced by the countermarked coins of Constans II used during the reign of Constantine IV. Arab-Byzantine and post-reform copper coins 


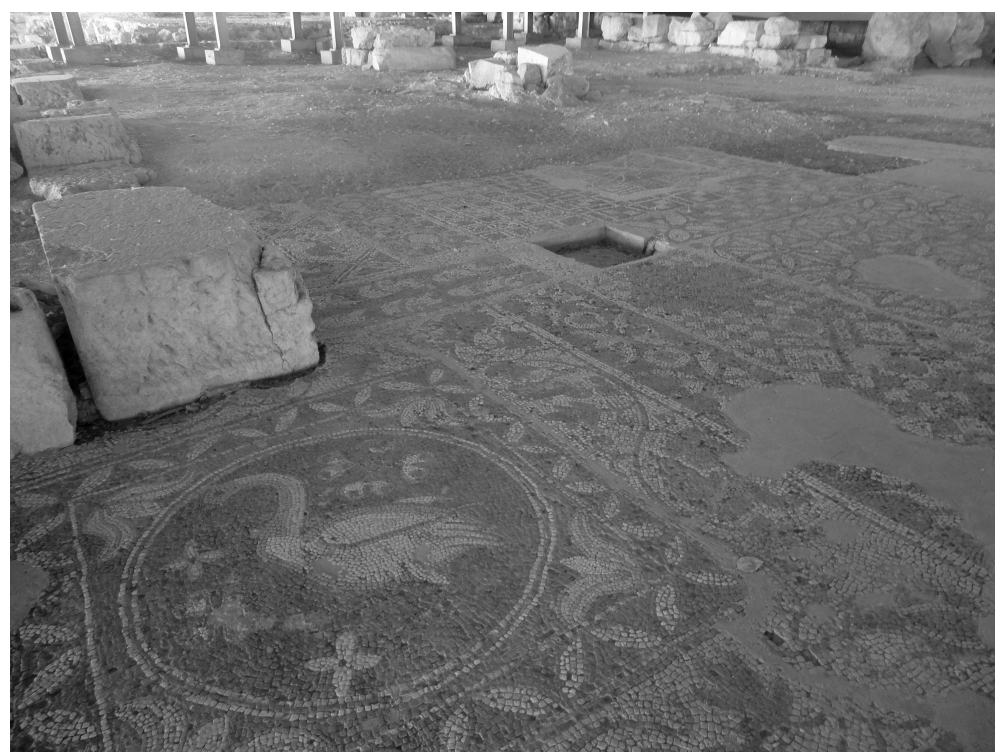

Figure 3.1 The Basilica at Soloi

(circulating alongside Byzantine issues) point to a common Byzantine and Arab frequentation of Cyprus and to the island's important role in linking the regional economies of Syria, Palestine, Southern Anatolia, and the Aegean from the late seventh well into the eighth century. ${ }^{95}$ As mentioned above, this typology of coins has until often escaped full scholarly attention, and one suspects that Arab-Byzantine specimens (in particular those yielded during the excavations at Salamis-Constantia ${ }^{96}$ ) often went unnoticed or were mistakenly regarded as Byzantine. As Metcalf has stressed, even a careful re-examination of the (few) Islamic copper coins included by Dikigoropoulos in his unpublished thesis provides useful indications of the (previously ignored) plentiful varieties that had accumulated up to 1961 in the Cyprus Museum. ${ }^{97}$ In other words, just as in Syria-Palestine:

An adequate treatment of ... transitional coins has not always been the case in the past ... a situation [whose] root cause is very likely the poor recovery and publication record of many excavations. ${ }^{98}$

Comparison with Syria and Palestine allows us to question the idea of a partially demonetarized economy as structurally weak and less resilient to shocks. ${ }^{99}$ In other words, as the recently published results of excavations at Polis-Arsinoe clearly show, what has been labelled as ruralization at Cypriot urban sites is instead a seventh- and eighth-century townscape of workshops, roads, churches, and burials, in which luxury items, ceramics, and bronze coins have been discovered. ${ }^{100}$ In a similar vein, as will be seen, one can think 
of the artisanal and commercial households excavated at the "Huilerie" in Salamis-Constantia, the lower city in Amathos, and the Limeniotissa basilica in Paphos as reflecting continuity of local demand and production, stemming from and expressed through a different urban lifestyle, social fabric, and structures. ${ }^{101}$ I will return to this point in the section concerning architecture and buildings below. It suffices here to say, though, that one should discount disruption of economic activities and rather consider the regionalization of copper coin distribution as representing the localization of exchange networks and the adaptive strategies of communities. ${ }^{102}$ These strategies included locally produced coinage with diverse regional iconographic and stylistic inclinations and the interregional acceptance of different monetary units. ${ }^{103}$ Eventually, one should also bring gold coinage into the picture. Indeed, although consignment of coin to Cyprus by the central governments seemed to end with Tiberios III's reign, since coins of Leo III and his successors of the Isaurian dynasty have left almost no trace on the island, one should not be deceived into thinking that monetary circulation came to an end. ${ }^{104}$ Indeed, one should bear in mind the change in the fiscal structure of the Empire, because, as Haldon remarks:

The degree of actual monetization of economy (velocity and circulation of gold [and bronze] coinage) is perhaps less important than the degree to which gold coins could be relied as sound basis for calculation of natural values. ${ }^{105}$

$* * * * * * * * *$

Similar to the experience of using numismatic evidence, one feels on historiographical solid ground when considering sigillography. Indeed, courtesy of the recent authoritative and complete publication of Cypriot lead seals on the part of Michael Metcalf (partially reused in his book on Byzantine Cyprus) we can refer to a detailed catalogue of Byzantine lead seals spanning the sixth to the twelfth centuries. ${ }^{106}$ To this can also be added a section of the catalogue of Byzantine lead seals at Dumbarton Oaks. ${ }^{107}$ Lead seals on Cyprus belonged to administrative officials of the imperial government, leading members of aristocratic families and other private individuals, bishops, and archbishops. Therefore, as Metcalf points out, seventh- and eighth-century seals offer evidence about a restricted number of elite, all of whom possessed great power and wealth. Additionally, we possess only those seals that were thrown away, so we do not know how typical they are of the offices represented or of the balance between church and secular authorities. ${ }^{108}$ Although Metcalf admits that the real decline in the number of lead seals did not happen before the $850 \mathrm{~s}$, he nevertheless focuses on the secular role of the ecclesiastical authorities and points to the almost complete disappearance of lead seals struck by bishops in order to stress the abandonment of urban sites along the coast. ${ }^{109}$

Metcalf himself has recently reassessed his own conclusions for he has focused on six clusters of lead seals (of both ecclesiastical and secular types) 
dating from the late seventh to the mid-eighth century found during excavations at Paphos, Soloi, Lapethos, Salamis-Constantia, Amathos, and Kourion. ${ }^{110}$ Therefore, Cypriot sigillographic evidence could lead us to assert that in the seventh and eighth centuries the island was a standard part of the Byzantine administrative, military, and bureaucratic machinery. Since lead seals of mideighth-century Cypriot archbishops have also been found on the island, it is possible to conclude that the involvement of the archbishopric and bishops in the local political system from late seventh century on was complementary to the persistence of the redistributive fiscal role of the Byzantine state as paired with a militarized fiscal system geared to the supply and maintenance of soldiers. ${ }^{111}$ Ralph-Johannes Lilie has indeed proposed a possible structure of the civic and fiscal administration on the island as reflected in the titles born by the seventh- and eighth-century seals found on Cyprus. ${ }^{112}$

The governmental and ecclesiastical flavour of the recorded specimens should not conceal the persistence of the sealing activity on the part of local magnates invested with high court titles such as palatini, illustrioi, and spatharioi, which continued at least until the end of the seventh century and maybe beyond. ${ }^{113}$ On the one hand, the involvement of Cypriot aristocratic families in the local structures of government points towards fluid and adaptive strategies on the part of the local representatives as part and parcel of the Byzantine imperial fiscal administration. Constantine Porphyrogennetos's De Administrando Imperio mentions three members of the Cypriot aristocracy (phangoumeneis) who were part of an embassy sent by Justinian II to Damascus to negotiate the repatriation of some Cypriot prisoners. As will be seen, the phangoumeneis may lie at the very origins of the provincial clan and families that built on the positions, offices, and high status enjoyed in their own provinces to become important in the middle Byzantine service elite. ${ }^{114}$ Though politically prominent, the local nobility was certainly poorer than before, as we can hardly distinguish their presence through the usual forms of political and social selfadvertisement. However, their prominence may have partially stemmed from their roles as cultural brokers within the Cypriot medieval middle ground. Recent remarkable works of Reimitz and Coureas (among others) have demonstrated the importance of cultural brokerage (attached to imperial power) as an analytical tool in historical research and interpreted it not "as a simple mediator but as a creative performance in those contexts characterized by a complicated interplay of local and extra-local influences". ${ }^{115}$ I will return to this problem in the following chapters. Suffice it to say here that the willingness of important local representatives to act as negotiators constitutes an essential element in shaping the middle ground. As these activities were inevitably to their political advantage, they could also violate the usual norms of their own cultures and create cultural demands of their own. ${ }^{116}$

Although it is very difficult to reconstruct the patterns of land-oriented local politics, it seems possible to conclude that local elites not only remained organized as informal sociopolitical groups, but also retained commitment to governmental responsibilities. ${ }^{117}$ Indeed, Prigent and Metcalf have recently 
observed that a surge in the number of specimens belonging to imperial officials seems to take place from the second half of the eighth century onwards, possibly reflected in the appearance of seal specimens belonging to archontes and the documented presence of seals issued by imperial strategoi from other provinces. ${ }^{118}$ In a sense, sigillographic evidence sketches a significant picture of Cypriot society, for

there is a significant contrast between the assemblages of seals from before and after 725; after that date seals of officials, dignitaries and the ecclesiastical hierarchy make up the great majority of all seals in Cyprus. ${ }^{119}$

This allows us to countermand the mainstream narratives depicting the island either as fully (or partially) militarized as a strategic outpost along the Byzantine-Arab frontier or as an experiment of neutralized buffer zone or, eventually, as an independent province administered by the local religious authorities. ${ }^{120}$ Instead, the analysis of lead seals dated to the seventh and eighth centuries points to a new ruling class, highly differentiated in terms of status, economic power, and sociopolitical functions, who inhabited a world in which traditional political and cultural customs were challenged, consciously explained, and modified in practice as different sides justified their own rules in terms of what they perceived to be the practices of the others. ${ }^{121}$ In this light, one should consider both the seals of the archontes (dated from mideighth century on) and the presence (also stressed by Metcalf) of Islamic seals (dated from the seventh to the eighth century). ${ }^{122}$ The former pairs with archontes seals found on other islands, like the Balearics, Crete, Malta, and Sardinia, and tallies with peculiar forms of insular political governance. Indeed, archontes were appointed as heads of local administration in areas of the Empire remaining formally under control of Constantinople because of their strategic importance, although de facto enjoying a degree of autonomy. ${ }^{123}$ In this they differ from the areas where more conventional (thematic) methods of administration and governance were in use, like Sicily. ${ }^{124}$ Changing political and cultural customs are exemplified in a seal bearing a peculiar iconography combining the imperial eagle with an inscription in Arabic. This points to the unique cohabitation of Arabs and Byzantines prompted by the proximity of the two communities on the island. ${ }^{125}$

Sigillography also prompts consideration of the economic role of the elites. Consider, for example, the above-mentioned seals of the kommerkiarioi found on the island, which reveal activities of trade and exchange (through local ports and entrepôts) with lands outside the Empire (or within it, as the seals of a Sicilian kommerkiarios found on Cyprus show). ${ }^{126}$ Ultimately, the complexity of the links between central government, provincial society, and the wealth of local aristocracy is revealed in the continuous sealing activity of private individuals. In particular, one should stress here the discovery of two lead seals found in the burial area around one of the churches excavated at Polis-Arsinoe. At least one of the specimens belonged to an aristocratic 
woman and is interpreted as a sign of her social distinction, ecclesiastical connections, and possibly a high level of literacy. ${ }^{127}$ One is tempted to search the forebears of the members of the local informal elites in the high-rank recipients of the so-called David plates. ${ }^{128}$ This mid-seventh century set of nine circular silver plates in different size was in all probability donated by Emperor Heraclius to an aristocratic family of Lambousa-Lapethos (on the northern coast of the island) as a commemorative gift or a token of gratitude for their support during the war against the Persians. Indeed, we can regard the dishes as precious artefacts of expensive material made by skilled artists as well as indications of the wealth of their owners, who showed a sophisticated degree of learning by boasting their appreciation for classical themes of the decoration. ${ }^{129}$

$* * * * * * * * *$

The analysis of late seventh- and eighth-century ceramics produced, imported, and distributed in Cyprus has only recently begun to occupy the minds of researchers, ${ }^{130}$ although in the early seventies Catling and Dikigoropoulos had already brought to scholarly attention the seventh- to eighth-century handmade pottery (the so-called Dhiorios wares) produced in the MitseroPolitiko area and the elaborate network of ceramic kilns related to it. ${ }^{131}$ Interest in the pottery of the so-called Dark Ages has almost evaporated since then, although when analysing the early medieval ceramic material found in the Canadian Paleopaphos survey in the late eighties, ${ }^{132}$ Thomas Gregory admitted that "the problem must be our inability to recognize the local pottery of this age, thus leading to the virtual disappearance of the period from the archaeological record" ${ }^{133}$ Gregory was not alone in pointing out our inability to step into the darkness of early medieval Cypriot pottery, for both John Hayes and Tassos Papacostas recognized that part of the issue was the loss of usual ceramic typologies around the 640s, resulting in the scarcity of the previously accepted elements for dating. ${ }^{134}$ Similar problems occurred in identifying and correctly dating the late seventh- to early ninth-century ceramic corpus in Syria and Palestine, problems that were only recently overcome. ${ }^{135}$

Here, as Walmsley shows, getting reliable answers about classification and dating of medieval pottery required, in the words of von Wartburg:

Parting with the pragmatically helpful but methodologically unsupportable parallelism of politics and pot production as a mainstay of chronology. Instead we have to think in terms of intense cultural osmosis in which polycentric production of pottery was part of the structure of the economy. ${ }^{136}$

Indeed, in Syria and Palestine the advancement in classification of the eighthcentury ceramic corpus has led scholars not only to recognize that cultural traditions adapted slowly to a new political situation, but also to identify the networks of production, distribution, and commercialization. ${ }^{137}$ In Cyprus, 
however, the full of effect of a revised chronology and typology of seventh- to ninth-century ceramic groups is still to be felt. ${ }^{138}$

However, in the last decade, as briefly mentioned in Chapter 2, a large number of scholars have rejected the idea that the end of imported fine wares and amphorae in the seventh century led the local population to rely more and more on less sophisticated and simplified ceramic types as a result of the island's shift from a prosperous Roman province to an unstable frontier. ${ }^{139}$ Indeed, the problem is twofold: avoiding generalization resulting from single key studies and restraining from adopting a simple quantitative approach focusing on the dwindling of imports as they were replaced by local products. The former would risk confining the analytical gaze to the persistence only of intra-island distributive networks based on local tradition mirroring the island's reduced circumstances. ${ }^{140}$ The latter, as Metcalf himself concedes, stems from the difficulties in cataloguing late seventh- to ninth-century ceramics and could precipitate parlous conclusions such as the supposed total abandonment of sites where fine wares disappeared. ${ }^{141}$

For instance, Zanini and Vroom have encouraged us to pursue a rather anthropological approach to the study of ceramics. ${ }^{142}$ If embraced this approach should allow us to move beyond a merely quantitative look at the assemblages and focus on the functionality of pottery, for as Vroom states: "Functional requirements of pottery have always been ignored and therefore limited the use of ceramics as a source of historical and sociocultural information". ${ }^{143}$ Focusing on functionality has revealed the utility of various types of pottery in Cyprus, such as the identification and classification of a group of vessels called authepsae capable of withstanding high temperatures. Previously, these single- or double-handled containers (now firmly dated to the seventh- to eighth-century) had been overlooked by excavators when found at Cypriot sites like Amathos, Alassa, and Salamis-Constantia. The correct identification of authepsae (as well as their comparison with similar vessels from ninthcentury assemblages in Amorium and Sarachane) opens up new lines of inquiry and analysis linked to mechanisms of daily life and the relationships between the people who used pottery directly or indirectly and the different macro- and microeconomic systems in which they lived. ${ }^{144}$

In this light, one could regard handmade pottery as a sign of shifting economic concerns and narrowing patterns of exchange, whereas its practical and economic utility ensured that its production would persist in the rural household. Moreover - as Vionis and Paul Arthur have convincingly argued - changing patterns in cooking practices and eating habits should also be considered:

The number of retrieved early medieval vessel forms is noticeably more confined and the proportion of wares associated with food processing is larger than that associated with food consumption. ${ }^{145}$

One should not imply that increasingly local production was equivalent to regional isolation, urban and rural settlement breakdown, and commercial 
immobilization. A study, revealingly entitled "Stumbling into the Darkness", 146 has for instance helped us to grasp the idea that decreases in the most common dating tool (i.e., coins), does not imply that settlements were equally diminished or ceased altogether: there is often no break in the ceramic record even when there is one in the coin evidence. ${ }^{147}$ Through the analysis of ceramic assemblages (amphorae, handmade pottery, and cooking wares) found in the excavations at the theatre of Paphos, it has been revealed that occupation in the area lasted beyond the date of the last associated coins (third quarter of the seventh century), and there is striking evidence of continuing trade and economic activities at Paphos well into the eighth century. ${ }^{148}$ More important, however, archaeologists have also shed light on the importance of recognizing locally made plain, painted, and cooking wares as are found in many urban and rural centres across the island, like Salamis-Constantia, Saranda Kolones, Yeroskipou, and Kourion. All of these factors allow us to point to a fragmentation of regional industries and developing regional differences, but not regional seclusion. ${ }^{149}$

Further elaborating upon this conclusion, Pamela Armstrong has shown that some of these ceramic types (including some later elaboration of Cypriot red slip fine wares) were exported to sites along the Asia Minor and Levantine coast and as far inland as Jordan and Palestine, mainly through the harbour of Caesarea Maritima on the Palestinian coast. ${ }^{150}$ Armstrong states:

The main historical significance of extending the date of Cypriot red slip wares and identifying associated ceramics (Dhiorios pots) is the way to demonstrate that the Arabs' arrival did not precipitate a major caesura c. 700. On the contrary archaeological evidence shows that the Arabs interacted positively with their new neighbours (and therefore the effects of the raids were overplayed in the Byzantine archaeological records). ${ }^{151}$

If the role of Caesarea as an import funnel and focus of maritime trade (although on a diminished scale) in the Umayyad period has often been exalted, a further point is worth being made here. ${ }^{152}$ As Vroom has argued convincingly, not only were several types of wares in use in periods after the seventh century across the eastern Mediterranean, some pottery (like later forms of Cypriot red slip wares) did not disappear, as commonly assumed, and remained in use for a longer period. ${ }^{153}$ Armstrong has argued convincingly the case for Lycia:

If we accept the end of chronology for Cypriot late Roman wares as c. AD 700 then ... the [Lycian] landscape is blank throughout the eighth century until the ninth century.... But if we accept a later chronology ... then a much more complex and realistic picture emerges of what is happening in the rural landscape in the eighth century. ${ }^{154}$

As a result, and leaving aside the intriguing possibilities of a larger reuse of wares (especially containers) ${ }^{155}$ and the idea that wooden artefacts could have 
replaced flatwares and amphorae in heavily forested areas (like Cyprus), ${ }^{156}$ one should consider that fine-ware plates (although of a far lesser quality than their predecessors) were circulating far beyond the so-called final phase of the Mediterranean-wide exchange in late Roman wares. ${ }^{157}$ Once again the importance of comparative studies is essential to fully grasping the complexity of a more localized but nevertheless still vital movement of goods across different regions and subregions of the eastern Mediterranean, which found in Cyprus its strategic focus. ${ }^{158}$ In particular the excavations at Lymira in Cilicia have revealed that the majority of the so-called "dark ages wares" found in the city consists of amphorae, fine wares, and cooking wares imported from the Near East, Egypt, southern Anatolia, and, above all, Cyprus. I will return to this in Chapter 6, but I would like to stress here that what might emerge is a picture of far more coherent interregional networks and integration than previously thought. The analysis of amphorae is in tune with productions (mainly later versions of LRA1 types) and imports (so-called globular amphorae as well as Palestinian and Egyptian containers). ${ }^{159}$ One should also consider the distribution of Cypriot cooking/coarse wares, which in the excavations at Kourion constituted a large part of the eighth- to ninth-century material. Even without a precise date, they must be regarded as markers of continuous occupation at the site in that period. ${ }^{160}$

Indeed, the study of this diagnostic ceramic group is still in its infancy in Cyprus, compared with regions like Syria, Palestine, or Crete (so-called ceramica sovradipinta). ${ }^{161}$ Vroom alerts us that the chronology of Cypriot cooking wares has been aligned with seventh- to ninth-century Constantinopolitan glazed wares as yielded in Salamis, Paphos, Soloi, and other important sites. ${ }^{162}$ However, Rautman asserts that eighth-century Cypriot cooking pots were circulating beyond inter-island distributive networks, being imported in Palestine and southern Asia Minor and travelling as far away as the Adriatic. ${ }^{163}$ Recent excavations in Sagalassos in south-west Turkey, for instance, have revealed a number of seventh- to ninth-century imported amphorae for long-distance trade, suggesting

economic links with places where the distribution of such amphorae has been identified, such as the inner Aegean area, Crete, Cyprus, the Levant, Sicily and southern Italy ... rather than suiting an isolated community in the Anatolian interior. ${ }^{164}$

As will be seen, Cypriot handmade pottery circulated alongside glazed white ware produced in Constantinople and post-LRA2/LR13 globular amphorae in a seventh- to ninth-century interregional pattern of exchange strategically cantered upon Cyprus. Globular amphorae have been documented in different areas of the Mediterranean from Malta to Butrint to Otranto. ${ }^{165}$ A more localized production and reduced demand than in the sixth century characterized the period under scrutiny, but they were sustained by basic-pattern provincial taxation levels (on the part of both the Byzantine and Umayyad 
states), the persistence of pockets of urban-oriented local aristocratic wealth (secular or ecclesiastical), the continuous role of Constantinople as a political and economic centre, the buying power of Egypt (the richest and most complex region of the Mediterranean), and, finally, the regional structures of power in Syria and Palestine. ${ }^{166}$

In other words, as I have tried to assert, ceramic evidence is once again taking us away from the idea of an impoverished and depopulated island with a simple and self-contained economy. ${ }^{167}$ Rather, it suggests that Cyprus was a frequented hub not only bridging the regional and subregional economies around it, but also showing persistent levels of sophisticated local production surviving (and even benefiting) from the fragmentation of the Mediterranean exchange system. ${ }^{168}$ As Cypriot ceramic types travelled across and beyond the eastern Mediterranean, Cyprus seems to have survived the effects of a breakdown in regional demand, as the local elites (often vested with governmental or church functions) and the fiscal system helped to underpin regional economic sophistication.

$* * * * * * * * *$

One of the problems that has puzzled archaeologists researching the architectural history of Cyprus in the period under consideration has been the almost complete lack of association between later types of ceramics and buildings. This has more often than not led scholars like Rautman to associate the seventh- and eighth-century pottery mainly with demolition phases or with poor and hastily done reconstructions. ${ }^{169}$ One might be tempted to conclude that a simpler pottery making process (stemming from a shift from large specialized fabricae to small households) went hand in hand with the destruction of edifices (mainly the wooden-roofed early Christian basilicas) and the end of artisanal manufacture related to building activities (like the roof tiles produced in the workshops of Kalavasos-Kopetra). ${ }^{170}$ Although the idea that the Arabs were completely to blame for the destruction of fourth- to sixth-century churches has been questioned, mainstream historiography has given much attention to the fact that the surviving monuments of the island are relatively small and no significant evidence can be used to trace the development of Byzantine architecture in general. ${ }^{171}$

However, as we have already mentioned, this conclusion is tainted by two methodological gaps in scholarly research: the overwhelming role played by ecclesiastical buildings and the lack of attention paid to the development of urban fabric evidenced by developing commercial and artisanal functions. ${ }^{172}$ The former descends partially from the fifth- and sixth-century Cypriot rural and urban landscape stunningly dotted with three- and five-aisle basilicas, lavishly decorated with marble slabs and mosaics. ${ }^{173}$ Metcalf points out that

these churches have been the main focus of architectural historians' interest.... At the same time [though] art historians have been concerned 
with their decoration with mosaics and frescos ... some of the details of the ground plans may arise from liturgical requirements. ${ }^{174}$

As a result, the following centuries were simply neglected or looked down upon as a period when no ambitious buildings were erected and no coherent decorative programmes were planned or executed. Other types of evidence were sometimes used, however, to coyly try to adjust the focus. Two famous inscriptions found at Soloi confirmed the reconstruction of the local episcopal church in the mid-seventh century, whereas the contemporary Life of Theodore of Paphos reports that frescoes were "rediscovered" in the church of Trimithus in 655 and, finally, the Acts of the Seventh Ecumenical Council of Nicaea (787) state that icons worked miracles in some churches of Salamis-Constantia. ${ }^{175}$

Nevertheless, scholars remained more interested in the role art in particular played in bolstering the view of Cyprus as the bulwark of Orthodoxy during the Iconoclastic controversy:

Iconoclasm like other heresies found no favour in Cyprus as pointed out by the survival of pre-Iconoclastic mosaic decoration at Panagia Kanakaria, Panagia Angeloktistos and Agia Mavra and Agia Salomon. ${ }^{176}$

Curiously, however, until a few years ago the unpublished thesis of Dikigoropoulos remained the only scholarly overview of the buildings erected or restored during the so-called Iconoclastic era, focusing both on churches (in particular the urban cathedral of Saint Epiphanios in Salamis-Constantia) and on civil architecture. ${ }^{177}$ Eventually, in the last decade, two seminal works (unfortunately only partially published) were produced by Papacostas and Stewart. ${ }^{178}$ Although dealing mainly with ecclesiastical buildings, they demonstrated beyond any doubt that building activities took place in Cyprus in the eighth and ninth centuries. In particular, Stewart's detailed architectural and iconographic analysis of the barrel-vaulted churches that dotted the Karpas peninsula has allowed him not only to demonstrate that they were built in various moments during the whole eighth century but also to compare them with similar buildings erected in Paphos (Panagia Limeniotissa) and Salamis-Constantia (Saint Epiphanios). ${ }^{179}$

Since these scholars devoted their research to ecclesiastical buildings, civil architecture remained neglected, with the exception of the fortifications erected sometime in the second half of the seventh century in different urban centres across the island. In particular, one should take note of the polemical debate among scholars such as Dikigoropoulos, Megaw, Karageorghis, Stewart, Balandier, and Metcalf concerning the events triggering the erection of such massive ramparts in Salamis-Constantia, Paphos, Amathos, and Kyrenia. ${ }^{180}$ Inevitably the Arab raids have been regarded as the foremost cause for the building of fortifications and regarded as one side of an equation including the abandonment of most of the coastal sites, the shrinking of the surviving cities into a well-fortified core, the total collapse of the classic urban layout, 
and the militarization of urban settlement. As the walls were neither hastily erected nor poorly built, it possible that, as Balandier states, they were of a piece with a general Byzantine defensive strategy during the last decades of the seventh century and not the result of an entrenchment brought about by the mid-650s Arab raids. ${ }^{181}$ As I have already written elsewhere, however, there is no need to conclude that urban wealth in the social milieu of the well-to-do was largely destroyed, and with it much of the dynamic church life. ${ }^{182}$ Indeed, if one compares the archaeological evidence from different Cypriot urban sites, it is possible to show that, like in nearby Syria-Palestine or in Byzantine Crete, two parallel trends can be observed: the continuation of Late Antique civic traditions and, at the same time, the introduction of new ideas about the crucial elements of the towns. ${ }^{183}$ The latter, in particular, can be identified through a detailed reassessment of older excavations (as in the case of the socalled workshops built in the "Huilerie" complex at Salamis-Constantia and the domestic quarter around the Panagia Limeniotissa in Paphos) and courtesy of recently uncovered evidence for workshops and other commercial activities (as in the case of the excavations at Polis-Arsinoe). ${ }^{184}$

I will return to the problem of Cypriot urbanism later, but I would like conclude this section by stressing that a careful reconsideration of the Cypriot urban history should reveal that from the second half of the seventh century some urban centres did benefit from intentional programmes of urban renewal, including church building, administrative complexes, and commercial-artisanal infrastructures. ${ }^{185}$ Like those in Syria-Palestine, some projects were supported by local ecclesiastical and secular administrators, such as the ramparts set up in Paphos, Amathos, or Salamis-Constantia, whereas others were underpinned by local elites. Both reflected different social and economic structures of urban patronage. In rural areas building activities were focused on churches, which probably acted as catalysts for new rural settlements. Although the profile of changing settlement patterns remains obscure due to the lack of sources, similar events in Umayyad Syria can help debunk the theory of internal migration and population shift. As Walmsley concludes:

The movement of a sizeable segment of the population to new, economically successful locations, both urban and rural, would have contributed to the gradual ... breakdown of the old social order of late antiquity [and] the emergence of a new refashioned society. ${ }^{186}$

$* * * * * * * * *$

As I have already set forth the diverse types of literary sources used to draw a picture of Cyprus from Late Antiquity to the early Middle Ages, this section will primarily present written sources according to the approach proposed by Enrico Zanini. He has encouraged historians (as well as also archaeologists) to

turn the tables of the relationship between archaeological evidence and historical interpretation, overcoming the mental habit, which has led us 
to (consciously or not) sift through "non-archaeological" sources in retrospect; this in the hope of using them to confirm the information gathered through the analysis of (supposedly) more objective archaeological data. ${ }^{187}$

Modern scholarship on early medieval Cyprus has more often than not shown the above-mentioned tendency when analysing literary sources. For instance, Christian and Arabic authors reporting on the Arab raids of 649 and 653/54 and the havoc these wreaked in Cyprus, such as Theophanes and al-Balādhurī, ${ }^{188}$ were used by Megaw and Karageorghis to argue convincingly that the walls of Salamis-Constantia were hastily erected in the immediate aftermath of the incursions despite previous investigation convincingly arguing for a much later date. ${ }^{189}$ Moreover, as Christides has demonstrated, the traditional narratives (in particular Christian) and exaggerated statements of the damage caused by the attacks has often led scholars to blame the Arabs for any layer of destruction documented during excavations. ${ }^{190}$

A rather glaring example is offered by the excavations at the so-called castle of Saranda Kolones in Paphos, where layers of destruction together with seventh-century pottery were found and attributed (without any proper explanation) to the Arab sack of Paphos in 654. ${ }^{191}$ According to Kyrris, this was enough to demonstrate that the castle had been built in the second half of the seventh century as a part of a large reorganization of Cypriot fortifications. ${ }^{192}$ Curiously, however, when further layers came to the light attributed to a glass factory in operation during the eighth and the ninth century, a different construction date was proposed by Megaw and linked to the supposed shortlived thematic militarization of the island under Basil I (867-86). ${ }^{193}$ The change in the administrative status of Cyprus is mentioned only by Constantine Porphyrogennetos in De Thematibus, written almost a century later: "The blessed and renowned emperor Basil [I] made it again one of the themes and posted there the general Alexios, an Armenian by nationality, who governed it for seven years". 194

As the elevation of Cyprus to the status of a theme has often been considered beyond discussion, even if we take the above-mentioned passage at face value, it is highly unlikely that a massive and carefully laid out structure like Saranda Kolones could have been planned and executed in such a short time span. In other words, caught in a vicious circle scholars were frantically looking at the few available literary sources available to explain the origins of the castle. ${ }^{195}$ It was John Rosser who finally correctly dated the building of the fortified structure to the thirteenth century and asserted that the only substantial Byzantine layers under the castle were those below the south-east tower belonging to a glass factory. ${ }^{196}$

We must be clear that we should not look for a separate probe of written and material sources. Rather, as Zanini remarks, we should pledge the adoption of

a cognitive process that would allow us to build up richer and more articulated interpretative models by reading non-archaeological sources 
in an attentive and punctual manner; this should be paired with the analysis of the possible meanings of each piece of archaeological evidence on order to recognize signs that are not clearly visible. ${ }^{197}$

By adopting such a model it is possible to contextualize episodes like the embassy sent by the Byzantine emperor to the Umayyad caliph in the mideighth century together with an imperial agent and the three above-mentioned Cypriot aristocrats called phangoumeneis. ${ }^{198} \mathrm{As}$ the phangoumeneis were in all probability members of local clans and families whose prominence partially derived from the positions, offices, and high status they enjoyed on the island, one should question and examine the available archaeological evidence in order to find traces of the existence of these elites and confirmation of their sociopolitical, and therefore economic, prominence. These stem from both explicit acts of self-representation (like monumental iconographies or euergetism) and from less obvious and "weak" indicators like pottery and, partially, seals.

The production, purchase, use, and dumping of daily objects reflect complex behaviours, which include how [members of the elites] regard themselves. ${ }^{199}$

With this in mind, it is possible to interpret the pottery imported to Cyprus or the seals struck in Cyprus as indicators of social status, while at the same time regarding the workshops documented in Polis-Arsinoe or SalamisConstantia as signs that the demand for pottery and seals was met not only through importation of goods.

By the same token, considering the weak signs can also help document the existence of a good level of demand from the middle strata of urban and rural society, as pointed out by local ceramic production paired with building activities well into the eighth century. ${ }^{200}$ These material records should allow us to breathe in the rarefied atmosphere of seventh- and eighth-century documentary and literary evidence concerning Cyprus. In this period we simply have fewer sources at our disposal than in the sixth and early seventh centuries, when - as mentioned in Chapter 2 - we benefit from two texts written by Leontios of Neapolis in the early seventh century (Life of Saint John the Almsgiver and Life of Saint Spyridon of Tremithous) and four locally produced hagiographies Cypriot saints. ${ }^{201}$ However, one must conclude, along with Stefanos Efthymiades, that most of the seventh- to ninth-century historical sources we have that mention Cyprus have an iconophile bias (including the eighth-century chronicle of Theophanes the Confessor). ${ }^{202}$ In particular, I would like to mention here the Life of Saint Stephen the Younger, written in the second half of the eighth century, which has been extensively referenced to argue in favour of the role of Cyprus as stronghold of iconophilia ${ }^{203}$ - a role historians have linked to the political independence of the island vis-à-vis the central government. Although the Life of Saint Stephen the Younger, according to Haldon and Brubaker, is a rather sophisticated text rooted in historical 


\section{4}

The mousetrap of methodology

reality and creating an impression of a reliable history, it is also deeply intertwined with monastic patronage (as it was written by a certain "Stephen Deacon" and dedicated to an abbot in Bythinia) and therefore shaped by the desire of the author and its patrons to disqualify the iconoclast party. ${ }^{204}$

I will return to the ideological program of this source in few moments, but first I should also stress the fact that not only hagiography but also the acts of ecclesiastical councils have often gone unquestioned. This is best exemplified in the conclusions Metcalf draws from the pro-iconophile sermons reported in the Acts of the Seventh Ecumenical Council of Nicaea (787), for he believes the reported stories help us to interpret the social and economic developments of eighth-century Cypriot society. But this heavily biased source is never discussed. There are many problems relating to the original form and preparation of these Acts, as well as with the translation into Latin, which is partially corrupted. ${ }^{205}$ Metcalf uses the Acts to sketch local society as predominantly rural because they are opposed to the iconoclasm. ${ }^{206}$ Although the same source also reports Cypriots travelling to and from Gabala in Syria (echoed by eighth- and ninth-century pilgrims travelling to Cyprus), mainstream historiography prefers pairing it with hagiographic sources (like the above-mentioned Life of Saint Stephen the Younger), which depict Cyprus as a backwater and isolated province. ${ }^{207}$ In fact, Brubaker and Haldon have showed that the Life of Saint Stephen is conclusively anti-iconoclastic and falsely describing Cyprus as iconophile bulwark. ${ }^{208}$ Evidence of Cyprus's iconophile leanings is missing, though mainstream historiography has often flirted with the idea because it is frequently asserted by the sources that the permanent iconolatry of the Cypriots can be explained by the traditional Cypriot conservatism and the lack of imperial control from Constantinople over the island owing to the neutral condominium. ${ }^{209}$

By viewing Cyprus as a de-urbanized and rural province, the traditional scholarly approach has also justified the lack of information about local conditions in the Christian and Islamic sources. In truth, as already partially mentioned, the invisibility of Cyprus in contemporary sources is not exclusive to the island, and can also be attributed to the compulsive scholarly attention given to the Arab raids and the treaty of $686-88 .{ }^{210}$ Indeed, the available Islamic and Byzantine sources mentioning Cyprus deal mainly with political and military events and therefore received the lion's share of scholarly attention; ${ }^{211}$ this explains why they have been carefully analysed and even included in exhaustive anthologies, whereas far less attention has been paid to the contribution of Syriac chronicles. ${ }^{212}$ These can help us not only to reconstruct the chain of transmission of information included in Byzantine sources but also to contextualize the events in Cyprus within a larger historical framework as paired with the (later) Arab written evidence. ${ }^{213}$

The importance of the corpus of Syriac literature as a geographical cluster showing mutual influence and deliberate borrowing (with its genesis in the 750s but better represented in texts of the twelfth and thirteenth centuries) has been fully stressed by scholars like Conrad, Palmer, and Howard-Johnston, 
among others. ${ }^{214}$ In particular, Lawrence Conrad's seminal research on Arwād (a little island off the coast of Syria raided by the Arabs in the aftermath of the first invasion of Cyprus) has recognized the fact that Syriac, Greek, and Christian Arabic sources for any historical event owe their similarities to their origins from a common source. The problem is, of course, can this common source be trusted? ${ }^{215}$ As James Howard-Johnston has argued convincingly, the common origin is a lost narrative written by Theophilus the Astrologer of Edessa in later Umayyad times, as it coherently included the main stages of the Arab conquest of the Middle East. ${ }^{216}$ This work was later reused by other Syriac chroniclers like Dionysius of Tel-Mahre, Jacobite Patriarch of Edessa from 818 to 845 , whose lost narrative, covering the period 582-842 was in turn used as a primary source by a later Jacobite Patriarch, Michael the Syrian, writing in the second half of the twelfth century, and partially preserved in the so-called Chronicle of 1234 written by a Syriac monk of the patriarchal monastery of Mar Barsaw. ${ }^{217}$

It is apparent that comparing the material transmitted by the latter sources with the information available in early Islamic and Byzantine written sources provides a fuller perception of the events occurring in Cyprus, while at the same time contextualizing them within the ebbs and flows of the naval confrontation between the Umayyads and the Byzantines: the rising Islamic tide attempting to conquer Constantinople (650s-670s), the failed siege of the Byzantine capital and the destruction of the Islamic fleet (674-78), the Byzantine counterattacks against various cities along the Syrian coast and the encouraged Mardaite depredations in Lebanon and Palestine, and eventually the treaty between the two empires in 686-88. A systematic comparison of Syriac and Byzantine and Arabic sources helps us to move beyond the date of the treaty to catch a glimpse of Cyprus in the eighth century through the eyes of, for instance, members of the famous Balkhi geographical school (dated to the tenth century but using earlier literary sources) like al-Istakhrī, Ibn Hawqal, and al-Muqaddasi ${ }^{218}$ In particular, the latter tells of the intense trade between Cyprus and the Muslims and provides us with an account of the Arab-Byzantine struggle at sea. ${ }^{219}$

The methodological validity of interrelating Arab and Byzantine written sources has been enhanced by Alexander Beihammer, who admirably used the Chronicle of Theophanes and the tenth-century Ta'rīkh al-Ras'ul wa'l Mulük of al-Tabari to reconstruct the nature and execution of the different naval expeditions mounted by the Caliphate against Cyprus from the seventh to the tenth century. ${ }^{220}$ This is not to ignore the challenges stemming from each typology of sources but to move away from a vision of the history of Cyprus based upon a single master narrative and towards a vision where scholars can adjudicate between multiple stories. In traditional scholarship, this attitude has been neglected as privileged themes (such as the origins of the treaty dated to $686-88$ or the iconophile loyalty of the island) emerged, de facto pairing the supposed geographic marginality of the island with its historiographic peripheral importance. 


\section{6}

The mousetrap of methodology

Indeed, the key lies in the interpretation of such words like margins and periphery, whose meanings can be reassessed in light of the typological, linguistic, and cultural diversity of written sources as matched with material evidence. ${ }^{221}$ One might regard this simply as a minor issue and privilege information transmitted by single typologies of primary sources in order to propose a rather simplistic version of Cyprus between Late Antiquity and the early Middle Ages as made of ruinous confrontations, demographic collapse, economic impoverishment, cultural backwardness, and political semi-independence supposedly predicated upon a pervasive religious orthodoxy; an image of an island paying a high social and economic price for its strategic role at the edge of two empires. But against this backdrop, one might instead propose a different interpretation, which matches a (re)-evaluation of the complexity and diversity of primary sources with a concrete set of material indicators. ${ }^{222}$ This allows us to not merely overcome the idea of an island as simply a strategic outpost of a regionalized Byzantine military system, but also to further enhance the notion of Cyprus as a middle ground. The latter concept, stimulating and provocative as it is, implies a degree of creative interaction (indeed, not always peaceful), which determined a world of complex economic links, adaptive political strategies, flexible administrative structures, and lively cultural exchanges as embodied by social actors and cultural mediators who travelled across the liminal space. ${ }^{223}$ It seems that by combining the information provided by the sources presented in this section, glimpses of this world can be obtained, although one should be aware that the jigsaw presents us with oddly shaped and often irregular pieces and leaves us with gaps caused, for instance, by a lack of archaeological excavations in the northern portion of the island and incomplete knowledge of ceramic typologies.

However, we can rely on the sufficient existing evidence to turn the tables. As marginality becomes less a flaw than a strength for local elites, Cyprus is revealed as more economically lively and better connected to both the Byzantine and Umayyad empires than traditional historiography has tended to believe. In fact, in the Cypriot middle ground the power struggle between the two states, which were not able to implement a full military and political grip on the island at the other's expense, did not bring about a cessation of human interaction but, to the contrary, created a fertile terrain of political, economic, and cultural ambiguity. This allows us to use sources to sketch what Deloria labels as "new theorizations of the working of powers in crosssocial situations that would try to account not only for physical forces but also cultural and ideological ones". ${ }^{224}$ By carefully regarding these forces not as an insurmountable border but a permeable frontier we can now propose a different analytical approach to the early medieval period in Cyprus.

\section{Notes}

1 Christie (1954).

2 Wineburg (2012). 
3 Brown and Kreiser Jr. (2007), xiii.

4 Wickham (2005), 8.

5 Milwright (2010), 26.

6 Ibid., 28.

7 Walmsley (2010), 48-68.

8 Rautman (1990), 147.

9 Metcalf (2004), 3.

10 Brubaker and Haldon (2007).

11 For a very preliminary introduction to the methodological problems of glass, metalwork, and textile industries see Laiou and Morrisson (2007), 77-9; also Dagron (2002). For metalwork see Papathanassiou (2002); for glass-making see Francois and Spieser (2002); for textiles see Muthesius (2002).

12 Taxel and Fantalkin (2011), 96.

13 Van der Wilt, Martinez Jiménez, and Petruccioli (2013).

14 Mitchell (2013), 8.

15 Wickham (2005), 702.

16 Dark (2001); Vroom (2003); Vionis (2013b); Zanini (2009b); Armstrong (2009); Walmsley (2007), 49-59.

17 Zanini (2009b), 76.

18 Randall (2013), 273.

19 Dark (2001), 25.

20 Walmsley (2007), 57.

21 Haldon (2012a), 107.

22 Morrisson, (2007), 221-8. Also Morrisson (2002), 929ff.; and Hendy (1985).

23 McCormick (2001), 380.

24 Ibid., 582-613.

25 Morrisson (2007), 229; Haldon (2012a), 108; Haldon (2012b) and Haldon (2016), 252-9.

26 Laiou and Morrisson (2007), 85; also Morrisson (2002), 918-30.

27 On the methodological and analytical implications of these two categories of coin finds, see below.

28 Laiou and Morrisson (2007), 87-8. Morrisson and Prigent (2011).

29 Walmsley (2010), 23. For the Bilād as-Shäm see Bosworth (1997), 291.

30 See Zavagno (2011), 469-75, for a detailed bibliography on the complicated issues of classification concerning the Arab-Byzantine coinage.

As Clive Foss (Foss 2008, vii) stated:

The Arab-Byzantine coins are notable for the use of images, some taken and derived from the Byzantine coinage, others original to the new Islamic regime. Their inscriptions are in Greek, Arabic, or both; they represent an unfamiliar mélange of the Christian and Islamic, but were all produced under a state run by Arabs and professing the religion of the prophet Mohammad.

However, Walmsley (Walmsley 2010, 28) further dwells upon this definition as he urges us to consider that

a somewhat broad categorization that does not sufficiently recognize important distinctions in language (Greek, Arabic) or symbolism (e.g., with or without Christian images) [has often been in use, as] this locally-mandated coinage introduced new visual concepts overtly political and cultural in intent.

Finally, it has been intriguingly argued that Syrian and Palestinian ecclesiastical authorities sanctioned the first substitutive coinage: see Walmsley (2010), 27. 
31 As Arab-Byzantine coins are often tiny, unattractive, badly struck, and hard to identify (Foss 2008, vii), past excavations were not able to properly identify them and put them in the same class as the Byzantine specimens that inspired them (like, for instance, the so-called Justin I and Sophia type or the folles of Constans II's reign). As a result, their presence (especially in old publications) may often go unnoticed or be mislabeled. Alan M. Stahl, Curator of Numismatics at University of Princeton (to whom go my warm thanks for his invaluable help) pointed the problem out to me, as he is currently reassessing the seventh-century Byzantine coins excavated in Antioch at the beginning of last century.

32 Walmsley (2010), 39.

33 Metcalf (2009), 177-82

34 Cheynet and Caseau (2012); also Metcalf (2013b), 128. For an introduction to Byzantine sigillography see Cheynet (2008), 1-82. I would also like to mention the recent online exhibition set up by the Dumbarton Oaks Research Center and Library Collection, one of whose curators, Dr. Jonathan Shea, has provided me with invaluable hints and comments in the course of the three summers I spent at the Center to research on this book. The site provides scholars with a detailed and updated bibliography on Byzantine sigillography: see http://www.doaks.org/ resources/seals (retrieved 1.11.2013)

35 Metcalf (2009), 69.

36 Metcalf (2004), vii.

37 Metcalf (2009), 69.

38 On the archontes see in particular Ahrweiler (1961), 70; 90-1; Brown (1975), 77; Prigent (2012), 82.

39 Metcalf (2009), 70; also Metcalf (2004), 393-401. On the Islamic lead seals see Metcalf (2004), 302; 500-2; Metcalf (2013b), 130; also Prigent (2012), 83.

40 Haldon (2012a), 113-14. On the kommerkiarioi and the endless debate concerning their function and economic role as mirrored by their lead seals see Oikonomides (2002), 983-8; Hendy (1985), 624, 626-34, 654-62; Haldon (1990); Haldon (2010a), 74-5; Dunn (1993); Cosentino (2011).

41 Baldini (2012), 245-6; Cosentino (2013a), 72-3.

42 A detailed inventory (although certainly not up to date) of the excavated early Christian basilicas in Cyprus can be found in Papageorghiou (1985a). See also Papageorghiou (1986), pp. 490-504. The most recent and complete scholarly publications concerning archaeology of urban and rural early Christian basilicas are those by Papacostas (1999), Rautman (2003), Stewart (2008) and Megaw (2007). See also Papageorghiou, Christian Art; Michaelides (2014); Michaelides (2001) and Nicolaou (2013). On the mosaics, see Chapter 1, n. 39; also Michaelides (1993).

43 See Papacostas (1999).

44 Mas Florit and Cau Ontiveros (2011), 211; for Malta see Bruno and Cutajar (2013), 16.

45 Fernández Delgado, Martinez Jiménez, and Tejerizo Garcia (2013).

46 Ibid., 170.

47 Ibid., 166.

48 McCormick (2001), 530.

49 Brown (2012), 492-6.

50 Ibid., 497.

51 Stewart (2014), 115-20.

52 Wickham (2009), 12.

53 Brubaker and Haldon (2007), 165

54 Ibid., 167.

55 Rapp (2015), 408.

56 Ibid., 199. See also Yannopoulos (1983), 84-6; and the more recent Efthymiadis and Déroche (2012). 
57 Brubaker and Haldon (2007), 188-99.

58 On the corpus of literature written in Syriac see Howard-Johnston (2010), 70-137; Palmer (1993); Haldon (2010a), 1-20. See also Griffith (2008). See also Brubaker and Haldon, (2007), 165-88. On the early Islamic literary sources written in Arabic see Kennedy (2004), 346-85; Christides (2006), 23-4; Robinson (2003); Sizgorich (2004) and Borrut (2011).

59 Conrad (1992), 336-7; also Borrut (2011), 69-75.

60 Noth (1994), 10-35; see also Heilo (2016), 17-46.

61 Howard-Johnston (2010), 425ff.; Kennedy (2004), 346-85; Mansouri (2001). See also the detailed contribution to the historical narrative from Arwād-Arados (a little island off the Syrian coast) on the part of Mu'awiya's arms in 650-1 (Conrad (1996).

62 Kennedy (2004), 348.

63 The indissolubility of the isnād/hābār relationship (the chain of guarantors and narration) is "the main characteristic of the Islamic historiography and harkens back to the format of the hadith [a report of statements and actions of the Prophet]. The duo are linked with the problems of affirming the truth (i.e., to vouch for the authenticity of an event)" (Borrut 2011, 21). The translation from the original French text is mine.

64 Mansouri (2001).

65 Christides (2006), 23-4; Mansouri (2001); Mansouri (2014). Beihammer (20002001); also Beihammer (2002).

66 Sizgorich (2004), 16.

67 Lounghis (2010), 118-19; Malamut (1988), 69.

68 Malamut (1988), 89.

69 Mansouri (2001); Mansouri (2014).

70 Delehaye (1925), 635-8.

71 White (1991), 99. See also Veikou (2015a), 54; Veikou (2015b), 368-72.

72 Wickham (2005), 8.

73 Wickham (2009), 255-97; Laiou and Morrisson (2007), 38-42.

74 Walmsley (2007), 24-5.

75 See Zavagno (2009) with further bibliography.

76 Dikigoropoulos (1961), 30.

77 Metcalf and Pitsillides (1995); Metcalf and Pitsillides (1997), pp. 1-7; Kyrris (1997), 668-9; Yannopoulos (1983); Metcalf (2003); Metcalf (2009), 141-213; Rautman (2003), 157-9.

78 Metcalf and Pitsillides (1995), 1.

79 Ibid., 7.

80 Metcalf (2009), 186.

81 Morrisson (2002), 955.

82 Ibid., 956-8;. Morrisson (1998), 307-34.

83 Cosentino, "Mentality", 72; Morrisson and Prigent (2011).

84 Wickham (2005), 736-41; Haldon (2012a), 111; McCormick (2001), 502-8; Morrisson (2002), 957-8; Prigent (2013). Also Nef and Prigent (2006), 16-22.

85 Wickham (2005), 737.

86 An excellent and detailed summary of the archaeology in Sicily in the last five years can be found in De Angelis (2012).

87 Walmsley (2007), 59. Indeed, as Rautman points out: "Coins could be interrogated in order to reinforce typology (classification), chronologically and statistically (currency or hoards) to yield information of economic significance and the relative social rank of the owner" (Rautman, 1990), 154).

88 Brubaker and Haldon (2007), 119.

89 Prigent (2006), 299 (the translation from French is mine); see also Zavagno (2011-2012), 125-9. 
90 Haldon (2012a), 109.

91 Indeed, I am perfectly aware that

Hoards are more amenable as they the concentration of coins in the years leading up to the terminus post narrows the likely date of concealment. Only hoards can show us how long a particular variety of coinage remained in circulation (although it goes without saying that hoards preserved the best available coinage as carefully chosen); on the contrary, stray finds obeys to different historical laws reflecting activity in monetary economy and that ideally we would need [to analyze] an assemblage of single finds from controlled excavations in different sites to establish a long term trend in monetary affairs. <Luca: There are a lot of grammar and syntax issues in this quote. A lot of the sentences don't work or make sense. Is this a translation? I figured that the original was in English, based on the author's name and the title of the book. If so, please check against the original text and make sure it matches. If it's a translation, then let's talk about how to make it read a little smoother!>

(Metcalf 2009, 145)

see also Zavagno (2011-2012), 475-6; here it is also worth mentioning the five gold hoards found on the island (Metcalf 2009, 167) and dated to the period 632-53. These seem to point to the flight of some well-to-do merchants or aristocrats from Alexandria to Cyprus after the final occupation of Egypt by the Arabs in 642. However, one should also keep in mind that - although this event affected the so-called Constantinopolitan tax spine (Wickham 2005, 626 and Wickham 2009, 260) - Alexandria was not forbidden to Christians in the second half of the seventh century for the Archbishop of Crete paid a visit to the city in 656 (Metcalf 2009, 167) and the seventh-century pilgrim Arculf (McCormick 2001, 174) got there a ship to travel to Constantinople.

92 Metcalf (2013a), 71-2; Hendy (2007), 403.

93 Baldini (2012), 268.

94 Cosentino (2013a), 71.

95 Haldon (2012a), 112; Dikigoropoulos (1961), 670; Foss (2008); Walmsley (2010), Metcalf (2013a), 73-4.

96 Callot (2004).

97 Metcalf (2009), 175-6.

98 Walmsley (2010) 24-5.

99 Ibid., 39.

100 A very strong approach on ruralization of urban sites (in particular those along the southern Anatolian coast) can be found in Akyürek (2008), 297-8; on PolisArsinoe and its continuous vitality see Caraher and Papalexandrou (2012), 274-5 and Caraher, Moore, Olson and Papalexandrou (2013), 79-82.

101 Zavagno (2011-2012), 153-5; Walmsley (2010), 40.

102 Haldon (2012a), 112-13; Walmsley (2010).

103 Walmsley (2012), 318-20.

104 Metcalf (2009), 177.

105 Haldon (2012a), 102-3; also Haldon (2012b), 3-4 and Haldon (2016), 249-90. On the steady rate of minting of gold coinage see Morrisson (2002), 922-9.

106 Metcalf (2004); see also Metcalf (2009), 69-139; Metcalf (2013b), Metcalf (2014), Metcalf (2013a), 73.

107 Nesbitt and Oikonomides (1991), II, 101-10.

108 Metcalf (2004), 7.

109 Metcalf (2009), 29; 99-103.

110 Metcalf (2013b), 133-4; also Metcalf (2004), 51-68. 
111 Haldon (1990), 224; Haldon (2012a), 100.

112 Lilie (2005), 82-5.

113 Metcalf (2004), 112-25; Metcalf (2013b), 130-2; Prigent (2012), 82.

114 Brubaker and Haldon (2011), 606.

115 Reimitz (2014), pp. 41-55; Coureas (2013), 231-44. The quotation is from Reimitz (2014), 44.

116 White (1991), 87.

117 Wickham (2005), 167-74.

118 Metcalf (2013b), 132; Prigent (2012), 83.

119 Metcalf (2004), 72.

120 Metcalf (2013b), 132; Lounghis (2010), 188-9; also Kyrris (1985); also Megaw (1985).

121 White (1991), 81.

122 Prigent (2012), 82-3; Metcalf (2013b), 130; Metcalf (2004), n. 356.

123 Mascarò and Moll Marcadal (2013).

124 Nef and Prigent (2006), 33-4.

125 Prigent (2012), 83.

126 Metcalf (2004), n. 221; Metcalf (2009), 119; Brubaker and Haldon (2011), 479-81.

127 Caraher and Papalexandrou (2012), 274-5.

128 On the David Plates see Leader (2000) with further and detailed bibliography. See also Metcalf (2009), 52-9 and Morales, Norris, Schwarz, and Watts (2001).

129 Morales, Norris, Schwarz, and Watts (2001), 13.

130 Armstrong (2009); Armstrong (2006); Randall (2013).

131 Catling and Dikigoropoulos (1970); Catling (1972).

132 C. Rupp (1987).

133 Gregory (1987), 200.

134 Hayes (1980), 377. See also Papacostas (1999), 41.

135 Walmsley (2007), 49-59.

136 Von Wartburg (2007), 425.

137 Walmsley (2007), 48; Walmsley (2012), 313-14.

138 Armstrong (2009), 158.

139 Vionis (2013b); Armstrong (2009); Armstrong (2006); Vroom (2003), 53-5; Vroom (2005); Vroom (2007); Vroom (2004); Randall (2013). Also Rautman (1998).

140 Rautman (1998), 87-9.

141 Metcalf (2009), 244-5.

142 Vroom (2012a); Zanini (2009b), 85-6.

143 Vroom (2012a), 344.

144 Zanini (2009b), 86.

145 Vionis (2013b), 36; see also Arthur (2007).

146 Smadar Gabrieli, Jackson, and Kaldeli (2007).

147 Armstrong (2009), 168. Armstrong (2006); Metcalf (2013a), 73.

148 Smadar Gabrieli, Jackson, and Kaldeli (2007), 793-7.

149 Ibid., 803. Also Randall (2013), 277.

150 On Caesarea, see Holum (2011), 11-17 with further bibliography.

151 Armstrong (2009), 175.

152 Wickham (2005), 774.

153 Vroom (2007).

154 Armstrong (2006), 25.

155 Lund (2007). Zanini has urged us to consider that some materials (in particular amphorae and roof tiles) are more prone to be extensively reused upon accurate selective process (Zanini (2009b), 86.)

156 McCormick (2012), 97.

157 Armstrong (2009), 159; Walmsley (2007), 52. 
158 Vroom (2005), 257.

159 Randall (2013), 276-7; Caraher, Moore, and Pettigrew (2010). Manning, Monks, Sewell, and Demesticha (2000); Demesticha (2013); Demesticha (2014).

160 Hayes (2007), 451.

161 Vroom (2005), 252-3; Wickham (2005), 786-7.

162 Vroom (2003), 54. Also Vroom (2012b), 369-70.

163 Armstrong (2009), 165-6; Rautman (1998).

164 Vionis (2013b), 30.

165 Vroom (2012b), 370-5.

166 Wickham (2009), 362-3.

167 Metcalf (2009), 245; Vroom (2012b), 391.

168 Cosentino (2013b), 99-101.

169 Rautman (1998), 84-7.

170 Given and Knapp (2003), 212-14.

171 Papacostas (1999), 9; see also Stewart (2008), 34-6 with further and detailed bibliography.

172 Papacostas (2013), 179.

173 It is almost impossible to summarize in a brief footnote the amount of literature devoted to the origins, architectural developments, and artistic decorative apparatus of the early Christian basilicas in Cyprus. Suffice it here to include the main overviews, which should be regarded as pivotal and to which scholars should turn as unavoidable starting points for any research on the topic: Papageorghiou (1985a); Koztakoğlou (2005), 465-788; Megaw (1974) and Langdale (2012).

174 Metcalf (2009), 253.

175 On Soloi, see Des Gagniers and Tinh (1985); Koztakoğlou (2005), 246-59; 694-717; Life of Theodore of Paphos, 21; Metcalf (2009), 444-6.

176 Dikigoropoulos (1965-1966), 271.

177 Dikigoropoulos (1961), 180-99.

178 The evidence collected in the $\mathrm{PhD}$ theses of the two scholars has been partially included in two later works: Papacostas (2001) and Stewart (2010).

179 Stewart (2008), 41-57. On the Limeniotissa see Koztakoğlou (2005), 502-12; on Saint Epiphanios see also Michaelides, (2001), 196-201; Papageorghiou (2008), 35-58; Papageorghiou (2011), 381-9.

180 Metcalf (2009), 270-2; Dikigoropoulos (1961), 228ff.; Megaw (1985a); Balandier (2003); Karageorghis (1960), 260-1; also Stewart (2008), 73.

181 Balandier (2002a), 200-2.

182 Metcalf (2009), 318. See also Zavagno (2011-2012), 132.

183 Walmsley (2007), 77. For Crete see Zanini (2013a) and Baldini (2012) with further bibliography.

184 Zavagno (2014).

185 Walmsley (2007), 90.

186 Ibid., 112.

187 Zanini (2007), 43.

188 al-Balādhurī (Hitti 1915), 13.235-6; Theophanes, (Mango and Scott, 1997, 344; 478).

189 Megaw (1985a), 209; Karageorghis (1960), 290; Dikigoropoulos (1961), 228; see also Stewart (2008), 73 and Metcalf (2009), 279-81.

190 Christides (2006), 23-5.

191 The best and most recent summary on the long and debated historical origins of the castle can be found in Petre (2012), 319-57. On Saranda Kolones see Megaw (1972); Rosser (1985).

192 Kyrris, (1970), 173-5.

193 Megaw (1972), 342; Megaw (1985b), 297-8. On the so-called Theme of Cyprus see Asdraxa, (2005) with further bibliography. 
194 De Thematibus 40, 17.

195 Metcalf (2009), 432-9; also Dikigoropoulos (1961), 60.

196 Rosser (1985), 95.

197 Zanini (2007), 43.

198 DAI, 224-5.

199 Zanini (2007), 41 also Zanini (2009b).

200 Haldon (2010a), 107.

201 Rapp (2014); Rapp (2015); also Efthymiades and Déroche (2012), 72-7 with further and detailed bibliography.

202 Efthymiades (2011b), 99.

203 Zavagno (2011-2012), 139-40 with further bibliography.

204 Brubaker and Haldon (2007), 234 47.

205 Ibid., 238.

206 Metcalf (2009), 446.

207 Efthymiades (2011b) 100.

208 Brubaker and Haldon (2007), 234-47.

209 Kyrris (1985), 201. Also Dikigoropoulos (1965-1966), 266 and Zavagno (20112012), 141.

210 For the origins of the treaty see Beihammer (2004).

211 Cameron (1992).

212 Beihammer (2004).

213 Conrad (1992), 349-54.

214 Palmer (1993); Howard-Johnston (2010); Conrad (1992).

215 Conrad (1992), 346-8.

216 Howard-Johnston (2010), 215.

217 Palmer (1993), xxi-xxii; also Hoyland (2011), 11-13 with further bibliography.

218 Christides (2006), 126; see also Mansouri (2001), 27ff.

219 al-Muqaddasī (Le Strange 1890, 82). Le Strange translates the passage of alMuqaddasī describing Cyprus as 'full of populous cities, and offer[ing] the Muslims many advantages in their trade thither by reason of the great quantities of merchandises, stuffs, and goods which are produced there.' The passage is also included by Cobham in the volume Excerpta Cypria (Cobham (1908), 5).

220 On al-Tabarī, see Christides (2006) with further bibliography. See also Beihammer (2002).

221 Herrin (2013).

222 Zanini (2013b), 3. See also Cosentino (2013b).

223 Zavagno (2013), 22-3.

224 Deloria, (2006), 22. 


\section{A history of Cyprus in the early Middle Ages}

\section{Cyprus from the sixth to the ninth century}

As conspicuously mentioned in Chapter 2, historiography has always been keen on presenting the political and ecclesiastical history of Cyprus between Late Antiquity and the early Middle Ages as swinging between prosperity and poverty, with a penchant for presenting the Arab invasions as the catastrophic no-way-back moment. As the reader has already been presented with an extensive overview of Cypriot historiography, this chapter will not pursue the issue any further and will instead be dedicated to a chronological outline of Cypriot political, military, and religious history. However, one cannot help but notice that we can trace this historiographic approach back to the midnineteenth century, when the French historian Louis de Mas Latrie wrote the Histoire de l'île de Chypre sous le Règne des princes de la maison de Lusignan, which included a cursory chapter on the so-called Byzantine domination of Cyprus. ${ }^{1}$ Indeed, in the eyes of the French scholar, in absence of any political events following the imperial capital's move from Rome to Constantinople, only natural disasters (like earthquakes and famines) disturbed the tranquillity of the island, where the local Church (initially under the patronage of Constantine's mother, Helen) bolstered its organization and gained independence from the patriarchal see of Antioch. ${ }^{2}$ Heavily borrowing from the Chronological History of Cyprus published in Venice in 1788 by the Archimandrite Kyprianos, Mas Latrie stressed that the archbishopric of Cyprus, at least nominally, recognized the supremacy of the Patriarch of Constantinople as it remained pivotal for the spiritual and political independence of the island throughout the entire Byzantine period; ${ }^{3}$ a period which was, however, characterized by "le temps le plux dèsastreux de son histoire [quand] Chypre fut tour á tour subjuguée par les Arabs". ${ }^{4}$

In a similar vein the British historians John Hackett, Rupert Gunnis, and George Hill, who in the first half of the twentieth century wrote general overviews of the history of the island (with colonial overtones), were inclined to regard the Arab incursions as ushering the island into a period of great misfortune. ${ }^{5}$ As we have seen, presenting the mid-seventh century as a historical watershed echoed contemporary early medieval historiography, in which, as Maria Parani states: 
The period of Late Antiquity, especially from the 5th century down to the first half of the 7th century, is regarded as a period of great prosperity for Cyprus, expressed in the construction of magnificent basilicas and their decoration. $^{6}$

Against this backdrop, one should choose a different starting point. By escaping from the constraints of traditional historiographical partition we realize that a drastic downsizing and reorganization of the eastern Mediterranean economic system should be moved back to the early seventh century, when Roman control over the whole Mediterranean broke after the brief and ill-fated Justinian Reconquista. ${ }^{7}$ Although Laiou and Morrisson regard the Great Plague of 541-42 and its cyclical return as a clear turning point in the economic history of Byzantium, ${ }^{8}$ McCormick deftly concludes:

If the waves of the Justinianic plague did unto Constantinople as the Black Death did to Florence, the population of the capital that needed annona diminished, lightening somehow the load for ships that were left. But the fall of Alexandria and its Nile breadbasket, first to the Persians, and then definitively to the Arabs brought the whole system to a grinding halt. ${ }^{9}$

To the latter one should perhaps add the coup d'état that brought Heraclius to the throne in 609-10, although - according to Metcalf - the almost simultaneous seizure of Egypt and Cyprus seemed not to disrupt the departure of the grain fleet from Alexandria. ${ }^{10}$ The strategic position of Cyprus along the annona shipping routes linking Alexandria to Constantinople is documented by both archaeological and written evidence. ${ }^{11}$ Although the state-sponsored shipment of annona commodities from Egypt did not monopolize the exchange network in the eastern Mediterranean as much as the provisioning of Rome did for the western Mediterranean until the Vandal conquest of Carthage in $439 .{ }^{12}$ An inscription dated to 530 and published by Gilbert Dagron argues that in the harbour of Seleucia Pieria an official collected fees from cargoes shipped not only from Egypt and Palestine but also from Phoenicia, Cyprus and Cilicia. ${ }^{13}$ Indeed, although the Mesaoria Plain provided a fertile strip of land between two massive mountain ranges, Cyprus did not actually have any particular agricultural or mineral potential (apart from some copper). In this way, it resembles much of the rest of the Mediterranean, except that it produced a little bit of everything - grain, wine, oil, animals, and timber - which other regions did not always manage. ${ }^{14}$ I will return to the geomorphological aspects of the island as they relate to the agricultural and economic potential. It suffices here to say that in mid-sixth-century Gallia, Cypriot wines were imported together with those from other areas of the eastern Mediterranean basin, like Crete, Samos, and Gaza. ${ }^{15}$

The role of Cyprus as a stepping stone in the eastern Mediterranean cultural and economic communication chain had been enhanced since its annexation to the Roman Empire in 58 вСE. ${ }^{16}$ After the battle of Actium, Augustus ceded 
the island to the Senate and Cyprus was, as Terence Mitford has put it, ushered into more than three centuries of serene anonymity benefiting from the privileges of the Pax Romana.$^{17}$ It seems highly possible that the island was regularly used as a hub on the main routes linking Syria to Italy and further west. ${ }^{18}$ With the administrative reforms brought about by Diocletian and Constantine in late third-early fourth century, the Roman province of Cyprus was included in the great Diocese of the Orient as a part of the Prefecture of the Orient. ${ }^{19}$ As two documentary sources - Laterculus Veronensis written in the early fourth century and Notitia Dignitatum in the early fifth century - show, the Cypriot province was headed by a vicar, whose title after 331 was Comes Orientis and who was seated in the metropolis of Antioch. ${ }^{20}$

On this occasion, the rank and title of the provincial governor of Cyprus also changed, for it had since been governed as a senatorial province, which meant that the governor was chosen by the Senate from its old members whose careers were already over. ${ }^{21} \mathrm{He}$ received the title of proconsul. ${ }^{22}$ Constantia (formerly known as Salamis), on the eastern coast of the island directly facing the Syrian coast, replaced Paphos, located at the southwesternmost corner of the island, as the capital of the province after a series of ruinous earthquakes, which wreaked havoc on the city in the second quarter of the fourth century. ${ }^{23}$

A further and important reshuffling of the administrative structures of the Empire, now firmly centred upon Constantinople, took place in the Justinianic period when the office Comes Orientis was demoted in 535 and merged with that of the Governor of the Province of Syria Prima, placing Cyprus under the sway of the Praefectus Pretorii in the capital. ${ }^{24}$ The real turning point, however, was the Novel 41 (now lost but partially preserved in the later Novel $50^{25}$ ) issued by Justinian in 536, which established the Quaestura Exercitus (quaestorship of the army) - a new office exerting military, civil, and judicial authority over a large territory including five former provinces of the Empire: Moesia and Scythia on the lower Danube and the Asian provinces of Caria and Cyprus, together with some Aegean islands (centred upon Rhodes). ${ }^{26}$ As Haldon points out, because the latter were all removed from the prefectorian prefect, they became the strategic backbone for supplying "the Danube frontier forces by sea from a secure hinterland, thus sparing the hard-pressed population and ravaged countryside of the frontier districts where the armies were based" ${ }^{27}$ The purpose of the newly established office was clear to John Lydus (an important member of Constantinopolitan bureaucracy), who in the mid-sixth century wrote a well-informed work on the power of the magistracies of the Byzantine state. ${ }^{28}$ One can infer from Lydus that in the eye of the central administration Cyprus was one of the wealthier provinces relied upon to secure the supply to the troops along the Danube frontier zone via the Black Sea and the lower course of the river. Once again Cyprus became of a piece with the route of the annona, although this time clearly a smaller version of the Egyptian one. This is further enhanced by an analysis of the distributive pattern of LR1 amphorae 
produced in Cilicia and Cyprus in this period. Stella Demesticha has demonstrated, for instance, that different amphora forms and typologies can be linked even to different functions within the Quaestura. ${ }^{29}$

This should come as no surprise if one considers the geography and morphology of the island as mirrored in its agricultural and raw mineral resources. Indeed, although characterized by the presence of two high and quite rugged mountain ranges (the Troodos in the south-west and the Pentadaktylos running parallel to the whole northern coast and stretching well into the Karpas peninsula), Cyprus boasts a large plain spreading between the two called the Mesaoria, reminiscent of the Messará Plain in Crete. Based on the island's geology, climate, and soil, one can identify four major parallel geomorphological areas: the northern coast, central lowlands, central highlands, and southern coast. ${ }^{30}$ The narrow north coastal strip in the shadow of the Pentadaktylos range, which falls off in height and steepness in the easternmost Karpas peninsula, is characterized by relatively frequent rainfall (especially where the mountains rise over 1,000 metres in the region between the two "Crusader" castles of Buffavento and Kantara) and perennial springs, which allow limited cultivation especially in the hinterland of the main harbour along the northern coast (Kyrenia) and on the Karpas (like on the plain of GalinoporniKaleburnu). ${ }^{31}$ In contrast, the central lowlands (the Mesaoria Plain) is fertile thanks to three rivers that crisscross it - the Pedias and the Yalias, both flowing into Famagusta Bay, and the Ovgos, running through the northwesternmost section of the plain) - and the accumulation of erosion from the igneous rocks of the Troodos and the Pentadaktylos mountains. ${ }^{32}$ As a result, Cyprus could boast a richer agricultural output than most surrounding regions, including cereals, fruits, olives, and (partially) wine. ${ }^{33}$

Indeed, the fertility of Cyprus, which lay at the heart of Justinian's decision to include the island in the Questura Exercitus as a supplier of the Danube army, was well known in antiquity. The island of Cyprus has been praised for its wealth since Roman times. In the first century $\mathrm{CE}$, for instance, the geographer Strabo wrote: "In excellence Cyprus falls behind no one of the islands because it is rich in wine and oil and uses home-grown wheat". ${ }^{34}$ One should keep in mind, however, that Cyprus could not be compared with areas such as Egypt or North Africa in terms of productivity and prosperity. Nevertheless, the island retained its fame of fecundity and productiveness well into the Late Antique period: Ammianus Marcellinus celebrated - among other things the apparent lack of imports, and the abundance of Cyprus was further extolled by Rutilius Palladius and Synesios of Cyrene, both writing in the late fourth or early fifth century. Other authors also sang the praise of Cypriot production, sometimes trespassing into the realm of myth, such as Nonnos of Panopolis who, writing in the early fifth century, exalted the island as a land blessed with honeyed fruits and horned animals. ${ }^{35}$

Though the Questura Exercitus did not survive the Avar and Slav invasions of the late sixth to early seventh century, Cyprus nevertheless continued to play an important role in the routes of the Egyptian annona replenishing 
Constantinople, as showed by archaeological excavations at the northwesternmost corner of the island at Cape Drepanon. ${ }^{36}$ There, a settlement (Agios Georgios) endowed with three basilicas has been identified as one of the possible stopovers of the grain convoys sailing from Rhodes to Alexandria. ${ }^{37}$ Indeed, the economic and strategic importance of the island along the eastern Mediterranean shipping routes reverberated in political events, which shook and reshaped the Byzantine Empire before the great Arab conquest of the Levant. Although, until the Arab invasions of Syria and Palestine, Cyprus remained under an hypatikos or consularis appointed by Constantinople and concentrating in his hands all the authority (including the collection of revenues), the island was central to the so-called Heraclian coup in 608-10 and the Persian War in the first decades of the seventh century. ${ }^{38}$ There is no space here to go into great detail, but scholars like Clive Foss, Mark Whittow, Walter Kaegi, and James Howard-Johnston, among the others, have produced a series of outstanding studies on both events. ${ }^{39}$ Instead, we should focus on the role Cyprus played on both occasions, starting with Emperor Phocas's accession to the throne following a revolt of the Danube army in $602 \mathrm{CE}$ after a series of military defeats both on the Persian front and in the Balkans, where the Byzantine military presence essentially dissolved and cities were left to their own devices against plundering groups of Avars and Slavs. ${ }^{40}$ Phocas's unpopular rule soon triggered a second revolt led by Heraclius, the exarch of Carthage, and completed by his son, Heraclius the Younger, and a Persian invasion targeting the richest eastern Mediterranean provinces of the Empire. ${ }^{41}$ Although the route of the "rebel" army and navy is controversial, it seems clear that Cyprus represented an important hub for the fleet that went by sea to Constantinople after the fall of Egypt at the hands of Heraclius's cousin Niketas in $609 .{ }^{42}$ Kaegi has argued convincingly that in all probability Heraclius himself did not set foot on the island, which nevertheless was "seized as part of an effort to hem in Phocas, create naval bases for possible future naval strikes against him, and to strangle him economically". ${ }^{43}$ That the "rebels" considered Cyprus essential to building up their resources before the last push towards Constantinople (which fell in $610 \mathrm{CE}$ ) is demonstrated by the fact that for the first time a copper mint was active in Cyprus, striking coins used in all likelihood to pay the Heraclian troops. ${ }^{44}$ The Cypriot mint - in all probability located in the capital, Salamis-Constantia - was one of the three that issued copper coins, the others being Carthage and Alexandretta. Indeed, the so-called Cypriot coinage of the revolt encompassed different denominations, from folles to small two-nummia, implying a rather complex and locally organized system of value. ${ }^{45}$

Notwithstanding the newly crowned emperor sitting in Constantinople, the fate of the Byzantine Empire did not look propitious as the war waged by the Persians already in $603 \mathrm{CE}$ continued to wreak havoc in the eastern provinces of the Empire. ${ }^{46}$ Heraclius was incapable of withstanding the tidal wave of the Persian army, which first conquered Syria and Palestine (Jerusalem fell in 614 CE and the Holy Cross was taken away to Persia) and later Egypt, where the 
capital, Alexandria, was conquered in $619 .{ }^{47}$ The latter episode is particularly relevant to our historical narration, because while Egypt was enduring the Persian raids, a large number of refugees, including bishops and local clergy with governors at their head, sought refuge in Alexandria. ${ }^{48}$ There they were comforted by the local patriarch John. Later known as Saint John the Almsgiver, the priest was

of the noble offspring and precious nursling of the island of the Cyprians, and was descended ... from ... an illustrious family and of brilliant renown. For John's father, Epiphanius ... was chosen by the rulers of that time to be entrusted with the reins of government in the island of the Cyprians. ${ }^{49}$

As already mentioned in Chapter 2, we are well informed about the life and deeds of the Patriarch of Alexandria thanks to the hagiography written by Leontios, Bishop of Neapolis (mod. Limassol), which has been dated to the second half of the seventh century. ${ }^{50}$ The hagiography was commissioned by the Archbishop of Cyprus, Arcadius (who died in 641-42), and Leontios heavily drew upon a previous life written by John Moschos (the author of the famous Pratum Spirituale) and Sophronius (later to become Patriarch of Jerusalem during the Arab invasions). ${ }^{51}$ The Life of Saint John is full of anecdotes and clichés. It pretends to summarize the patriarch's main deeds as witnessed by Archdeacon Menas of Alexandria, thus representing one of the few sources to provide first-hand information on the social and economic history of the period under consideration, although without any precise chronological reference. $^{52}$

Specifically, regarding Cyprus, the Life of Saint John aimed to enhance the religious prestige of Cyprus following a possible compromise between the local Archbishop Arcadius and the Monothelite movement. ${ }^{53}$ I will, however, return to this in the next section concerning the ecclesiastical history of Cyprus. The Life of Saint John is crucial because it refers to the role of Cypriot elites in the political, military, and religious administration of the island. ${ }^{54}$ John himself was the scion of a local aristocratic family from the city of Amathos who could boast strong links with the imperial administration (John's father was raised to the rank of patricius after the Heraclian coup. $)^{55}$ The wealth of the Cypriot upper classes referred to in the Life of Saint John is mirrored in the elaborate David Plates. As briefly mentioned before, this set of silver dishes was an act of extraordinary artistic patronage on the part of Heraclius, who wished to commemorate the victories of his reign (particularly the defeat of the Persians). ${ }^{56}$ The set was part of two large treasures found at the site of LapethosLambousa, a Byzantine city located on the northern coast of the island and nowadays almost completely gone. As Metcalf states, the treasures included

numerous items of gold ... in particular a girdle made of consular medallions and consular gold solidi, mostly of excessively rare types; and Epiphany/baptismal medallions ... worked up into an encolpion. ${ }^{57}$ 
There is no space here to further speculate on the date and events that led to the concealment of the treasures, but one should stress that it must have been owned by a conspicuous and high-ranking family, evidenced both by both the six solidi incorporated into the medallion and, above all, the control stamps engraved on the back of the silver plates to guarantee the quality of workmanship. ${ }^{58}$ Because the David Plates were produced - in all probability - in a Constantinopolitan workshop linked to the imperial mint and donated to a local Cypriot official as a form of imperial largesse, one should focus on their iconographic subjects, which are almost unanimously identified with the biblical events of the life of King David. ${ }^{59}$ The set of silver dishes was, in fact, a piece of imperial propaganda intended to present Heraclius as the new David chosen by God to rule and capable of defeating the Persian Goliath and restoring the Empire to its former glory.

The fight against the Sassanid Empire was almost fatal to the Empire. The war started on a triumphal note for the Persians, who within the first two decades of the seventh century invaded and conquered Syria, Palestine, and Egypt, stormed Jerusalem and took the Holy Cross to Ctesiphon as a spoil of war, severed the annona link between Alexandria and Constantinople, and finally dared to lay siege to Constantinople in collaboration with the Avars in $626 .{ }^{60}$ Only through brave but haphazard decisions, like the stripping of the ornaments of Constantinopolitan churches and the military expedition launched in the heart of the Sassanid Empire with the help of central Asian Turkic nomad tribes, did Heraclius manage to force the Persians to sue for peace and return all the lands taken in the previous two decades. ${ }^{61}$

However the road to ultimate triumph was difficult, and though the Persians seem never to have raided Cyprus, troubles on the island certainly hastened the collapse of Egypt. ${ }^{62}$ Indeed, the Life of Saint John the Almsgiver in a rather obscure passage refers to

a general, one Aspagurius by name, [who] had been sent to Constantia in Cyprus but had not been admitted by the town; so he prepared himself for war against its citizens and they on their side were arming themselves against him. And they were just on the point of engaging in this slaughter of each other when the all-admirable John, the disciple of the God of Peace, intervened and induced both parties to seek reconciliation and succeeded in bringing them to terms. ${ }^{63}$

We can only speculate about the reasons behind the refusal on the part of the citizens of Constantia to openly welcome the Byzantine military commander, whose Armenian name led some scholars to rather implausibly link his presence with the Armenian captives from Arzanene. ${ }^{64}$ The episode in question is indeed recalled by Theophylact Simocatta, who reported that the prisoners were transferred to Cyprus by the Emperor Maurice in $578 .{ }^{65}$ However, the episode, even if it really happened, had no serious repercussions on the importance Cyprus retained for the Byzantines during the Persian War as 
both a last line of defence and a launching pad for the retaliatory military campaigns against the Sassanids staged by Heraclius in the second half of 620s. This is showed not only by the passages of the Life of Saint John concerning the prisoners of war who were either rescued by the Bishop of Amathos or managed to escape their Persian captors to find shelter in Cyprus but also, and more importantly, by archaeological and numismatic evidence.

On the one hand, excavations led by the Department of Antiquities in the peninsula of Akrotiri (along the southern coast of the island) have yielded a monumental complex with a peculiar funerary character. ${ }^{66}$ According to Eleni Procopiou, the building, which boasted a T-shaped plan, should be pictured against the historical backdrop of Emperor Heraclius's wars and a passage of the Life of Saint John concerning a "divine church" built to lodge the relics of Saint Stephen Protomartyr in Cyprus. Although the latter assertion seems far-fetched, especially considering further conclusive evidence concerning the titulature of the church, one should see the building as part of the contemporary political framework: an act of piety supported by Heraclius deliberately propagating his image as a pious Christian king - an image that resonates with that set forth by the David Plates and the patronage of John the Almsgiver. ${ }^{67}$ On the other hand, we should look at the strong presence of Heraclius's copper coinage. Of particular note are a series of copper folles struck in Salamis-Constantia and dated to the period 626-29, which must be regarded as military issues indicating that an army was being raised on Cyprus in preparation for the military thrust against the Persians. ${ }^{68}$

Indeed, numismatic evidence aligns with the sigillographic, for a group of seals struck around the same time as the folles and bearing some uncommon double titles points to the persistence of both administrative and fiscal structures, which were (at least partially) bestowed upon local wealthy families who could also fill the ranks of the ecclesiastical authorities, as the Life of Saint John the Almsgiver reveals. ${ }^{69}$ When disaster befell Byzantine Egypt, John, in his function as Patriarch of Alexandria, was forced to leave the country and retire to his native Amathos, where he died and was revered as miracleperforming saint. ${ }^{70}$ As will be seen later, the role played by local aristocratic families who could perform duties using adaptive political strategies vis-à-vis the political, military, and even religious difficulties of the time, while at the same time shaping the local demand and breathing life into the Byzantine fiscal distributive patterns, represents a constant in the transitional period in Cyprus.

In this sense, it is difficult to overlook the beginnings of John the Almsgiver's career and his bid to the wealthy Patriarchate of Alexandria:

Under strong pressure from the Emperor Heraclius and largely through the counsel of Nicetas [his cousin] who at the time had been raised to the rank of "patrician" and shared the government of the Empire. ${ }^{71}$

In this capacity, John - although his Life is heavily tarred with the brush of an idyllic and ideal collaboration between the secular and religious powers 


\section{2}

Cyprus in the early Middle Ages

and is heavily tainted by the biased sympathy of his countryman author Leontios - proved to be an excellent choice on the part of the Constantinopolitan establishment, acting both as a mediator (as in the episode involving General Aspagourios or in coordinating the rescue of Byzantine war prisoners together with a Cypriot Bishop) and as a pacifier (he was active in the settlement of both civic and dogmatic issues, due to the number of Monophysites on Cyprus). ${ }^{72}$ John embodied the strong ties linking Egypt and Cyprus and may be regarded as one of the first examples of cultural brokers produced by the island in the course of the seventh and eighth centuries as a peculiar result of its exceptional position on the edge of cultural and sometimes political-military frontiers. As I will return to this in few moments, it suffices here to offer a preliminary definition of brokers as "agentes qui servant de stimulants ainsi que d'exécuteurs et qui se distinguent les uns des autres par leur motivation, leur capacité et leur degré d'implication dans ces processus". ${ }^{73}$

$* * * * * * * * *$

During a brief and deceptive period of peace following the military triumph of Heraclius over the Persians, Cyprus benefited from such important acts of imperial patronage as the possible restoration of the pentagonal towers of the fortress guarding the entrance to the harbour of Kyrenia and - above all - the rebuilding of the aqueduct supplying the capital Salamis-Constantia. ${ }^{74}$ As some inscriptions on the (now lost) arches supporting the conduit witnessed, the emperor deliberately impressed his mark on the city in collaboration with the local Church, for some archbishops (Arcadius in 628, Plutarchos in 635-36, and possibly Sergius in 640) were also commemorated in the inscriptions as generous benefactors. ${ }^{75}$ As I will return to the urban centres in a later chapter, the scope of current analysis will be limited to the political-military events of the first three decades of the seventh century, which clearly placed Cyprus at the very heart of Byzantine political structures of power as a military base and as a strategic hub along the Constantinopolitan fiscal networks. The munificent acts of imperial patronage coupled with the spiritual, political, and economic centrality of the local Church and were a direct consequence of the importance of the island in the eyes of the Constantinopolitan court. Therefore, it should come as no surprise that when the Arab invasions hit Syria and Palestine in the 630s, Cyprus became the focus of rear-guard actions as well as the bridgehead for Byzantine military counterattacks on the Muslim occupation of the Levant and, later, Egypt.

During the fatal third decade of the seventh century, when the Byzantines were engaged in re-establishing their tradition of imperial rule and administration in Syria and Palestine (and Egypt) after more than two decades of Persian domination, the spectacular and (to some extent) unexpected attacks by the army of the newly established Muslim Caliphate wreaked havoc in the Levant once again. ${ }^{76}$ It is worth mentioning that in the aftermath of the Arab 
victories in Palestine, the Byzantines regrouped in Cyprus. This is supported by numismatic evidence, which records a peculiar class of copper coins bearing Syrian countermarks with monograms of Heraclius found at Cypriot urban sites (Paphos, Salamis-Constantia, and Kourion) ${ }^{77}$ The countermarking and distribution of these coins allows us to date them between 633 and 636 and establish that they were struck in Caesarea Maritima, the fortified harbour along the Palestinian coast that withstood a seven-year Muslim siege before finally falling in $642 .{ }^{78}$ Since countermarking ended immediately after the Battle of Yarmuk and the retreat of the Byzantine army from Syria-Palestine and as the coins remained in use in Cyprus, it seems possible to conclude that in absence of a clear monetary or propagandistic purpose, we are dealing with military emissions. They began when the first Arab raids hit Gaza and the Dead Sea and continued, due to the urgent need of Byzantine reinforcement in the region. They were ultimately limited to Cyprus, where the troops could have found provisional shelter to regroup, for the island was also used as a convenient rallying point for the army (and even prisoners of war) during the confrontation with the Persians.

When, however, the Arabs invaded Egypt in late 639, Cyprus was on the front line. ${ }^{79}$ The Byzantines reacted to the Muslim blow delivered by the troops led by general 'Amr b. al-'As by landing an army in Alexandria in 645 . It is highly possible that those troops sailed from Cyprus, because the island according to Kaegi - was a hub for Byzantine communications, supply, the transport of troops between Constantinople and Egypt. ${ }^{80}$ When Muslim counterattacks forced the Byzantine expedition corps back and trapped them in Alexandria (a sort of Dunkirk ante litteram), the only option available to commander Theodore, in the words of the late seventh-century Chronicle of Saint John of Nikiu, was to re-embark "all his troops and officers [who] set out and proceeded to the island of Cyprus and abandoned the city of Alexandria". ${ }^{81}$ It was evidently clear to the Muslims that as long as the Byzantines remained in full control of the island, Cyprus would remain a thorn in the side of the armies of the caliph and an ideal base for retaliatory raids targeting the Syrian coast. ${ }^{82}$

Although it had seen little struggle during the invasion, Cyprus remained almost entirely populated by Christian communities and did not yet possess the defensive network of ribāt and thughür, which was put in place in the mideighth century. ${ }^{83}$ Moreover, the Arabs still lacked a fleet capable of confronting the Byzantine navy on open seas. Therefore, Mu'awwiya, the Marwanid governor of Syria and future caliph, clearly set forth his intention of seizing the island, in order both to take control of an essential hub on the sea route to Constantinople (the planned target of the Arab army now on the offensive throughout the Anatolian plateau), while at the same time putting to the test the newly built Muslim fleets prepared in Tyre and Alexandria. ${ }^{84}$ Two later Arabic chronicles - the Kitāb futūh al-buldān written by al-Balādhurī in the late ninth century and al-Tabarī's Ta'rîkh al-rusul wa' l mulük dated to the early tenth century - which refer both to the fact that Mu'āwiya pressed first 
Caliph 'Uthmān in 643 and his successor 'Umar in 645 to organize a naval expedition against Cyprus. ${ }^{85}$ It is clear that by the first half of 640 s the threat represented by the strategic role of Cyprus was too great to be overlooked. In order to further stress this point, al-Tabarī writes:

Due to the proximity of the Byzantines and the region of Hims ... the inhabitants of one of the villages of the region can hear the barking of their [the Cypriots] dogs and the singing of their birds. ${ }^{86}$

This is clearly a hyperbole often used by Arab authors to enhance islands' relative proximity to land: as in the case of Aradus-arwād (mod. Ruwād), a little inlet off the Syrian coast raided by Mu'āwiya in the immediate aftermath of the first Arab expedition against Cyprus in $649 .^{87}$ There was, however, a sense of urgency transmitted by the later Arab sources with regard to the threat Cyprus represented for the Arab conquest progress on the Asian and African mainland. ${ }^{88}$ One should also consider also that the Arab authors, in particular al-Tabarī (who could rely on a rich selection of isnāds that he carefully selected and edited in order to form a coherent and chronological narrative) clearly stressed that the raid against Cyprus was the first naval expedition mounted by the Arabs and that it was only obtorto collo that Caliph 'Uthmān gave Mu'āwyia permission to set the sails. Al-Tabarī states: "He [Mu'āwyia] do[es] not choose the soldiers nor draw among them but leave[s] them free voluntarily to take part in the expedition". ${ }^{89}$ Al-Balādhurī even reports that the caliph cajoled the governor of Syria into taking his own wife with him as a last resort to convince Mu'āwiya to renounce his intentions to invade Cyprus. ${ }^{90}$ However difficult it may have proved, Ibn Khayyat, a ninth-century Arab chronicler, states that not only did Mu'āwiya embark with his wife but he also convinced the admirals of the fleet to follow his example. He was accompanied by Bani Abd Manaf and his wife, Fakhita b. Qardha, as well as 'Ubada b. al-Samit and his wife, Oumm Haram b. Milhan al-Ansariya. ${ }^{91}$

The latter is in fact the subject of a well-known legend mentioned by Arab chroniclers such as al-Balādhurī and ibn al-Athīr (whose universal history is dated to the late twelfth to early thirteenth century) ${ }^{92}$ who note that Oumm Haram died after landing on the island when she fell from her mule and broke her neck. ${ }^{93}$ The body was then supposedly buried in a tomb, which is still a pilgrimage site for local Muslims today: the Halan Sultan Tekke, located just outside Larnaca. It is interesting to note that the episode - although quite distorted as far as its main characters were concerned - percolated into the Byzantine sources, as in the tenth-century De Thematibus by Constantine Porphyrogennetos: "The daughter of Abu 'Bakr, the first Muslim who crossed over Cyprus ... in the reign of Heraclius, died there and the place of her burial is still known". ${ }^{44}$

Leaving the legends of the conquest aside, one could better grasp the preparation and development of the Arab raids on Cyprus by coupling the sources written in Arabic with those in Syriac and Greek. ${ }^{95}$ In that way we can reconstruct not only the chain of events leading to the attacks but also the 
aftermath of the invasions. Indeed, in 649 Mu'āwiya decided to summon the Syrian and Egyptian fleets and crossed from Acre to Cyprus with a large number of ships, attacking and sacking Salamis-Constantia. ${ }^{96}$ However, as the Byzantine and Arabic sources do not provide us with any details concerning the plunder of Cypriot urban centres - the Life of Saint Therapon only mention that Kition, along the southern coast, was spared ${ }^{97}$ - we must rely only on the above-mentioned Syriac Chronicle of Dionysius of Tel-Mahre who mentions that Mu'âwiya took up residence in the bishop's palace of Salamis-Constantia while his companions plundered the city, collecting gold, slaves, and expensive clothing. Dionysius also says that the Arabs were elated by the astonishing quantity of loot and captives (of both sexes) they accumulated. ${ }^{98}$ However, the Arab fleet was soon forced to retreat once rumours of the imminent arrival of a Byzantine fleet lead by the admiral Kokokerizos spread across the island. ${ }^{99}$

It is interesting to note that the ninth-century Kitāb al-futūh of al-Balādhurī mentions the Coptic origins of the sailors manning Mu'āwiya's ships and - more relevant to our study - that before approaching Cyprus, the Arabs raided some Byzantine ships at sea. ${ }^{100}$ They were carrying gifts (precious silks and other luxury items, reminiscent of the Lambousa-Lapethos treasures) for the king of Cyprus from Constantine, son of Heraclius. ${ }^{101}$ Beihammer, indeed, concludes:

The correct identification of the Byzantine ruler in 649, which does not occur anywhere else in the tradition of Cyprus campaigns, shows a high degree of acquaintance with the broader historical background, so that the details must have an authentic basis. ${ }^{102}$

A second expedition against Cyprus is recorded a few years later, in 653 . According to al-Balādhuri and the early tenth-century chronicler Qudama b. Ja'far, whose Kitāb al-Kharāj records that the raids were triggered by the lack of respect given to a treaty signed when the Muslims left Cyprus in 649. ${ }^{103}$ Although scholars like Papageorghiou in 1960s, Kyrris in late 1990s, and, more recently, Mansouri, have written in favour of the existence of a preexisting version of the 686-88 treaty between the Arabs and the Byzantines, Browning, Christides, and above all Beihammer have disproved this assertion. ${ }^{104}$ In particular, the latter has concluded that a covenant of the type voluntarily signed by the Palestinian and Syrian cities and the Arab invaders in the 630s could have been put into effect on Cyprus between the local Cypriot authorities and the Muslims in the aftermath of the second incursion against the island. ${ }^{105} \mathrm{~A}$ trustworthy memory of such a covenant can be found (according to Beihammer) in the Chronicle of Dionysius of Tel-Mahre, who also mentions that the raid of $653 \mathrm{CE}$ wrought havoc at many Cypriot urban sites, such as Amathos, Lapethos, Salamis-Constantia, and Soloi. With regard to the latter, a city located on the Bay of Morphou along the western stretch of the north coast, a famous double inscription shows that the city was indeed hit during the second invasion. ${ }^{106}$ As I will return to the inscriptions later, it is enough to note here that the northern coast of the island seems to have been 


\section{6}

Cyprus in the early Middle Ages

the real epicentre of the confrontation during the second raid. Indeed, Dionysius of Tel-Mahre states:

When the Romans and the natives sighted the Arab ships on the horizons [they] shut themselves up in Lapethus.... The Romans took to their own ships and saved themselves from the Arab aggressions [whereas] the Arabs all gathered against Lapethus. [The city was bombarded until the inhabitants offered to surrender to the general] who showed clemency readily and sent them the following instructions: the gold and silver and other assets, which are in the city are mine. To you I give amnesty and a solemn pact that those who wish to may go to the Roman territory and those of you who wish to stay will neither be killed or enslaved. ${ }^{107}$

The alleged "final" destructions brought about by the invaders run counter to the archaeological signs of continuity. ${ }^{108}$ Apart from the rebuilding of churches (like the Basilica of Soloi and the Church of Limeniotissa at Paphos and the Basilica of Saint Epiphanios in Salamis-Constantia), there is also sufficient evidence pointing to the continuous occupation of residential buildings in Paphos, Salamis-Constantia, and Polis-Arsinoe, where economic and building activities are further enhanced by sigillographic, numismatic, and ceramic material yielded by the excavation at those sites. ${ }^{109}$

That the entire island of Cyprus acquired new military and strategic importance in face of the Arab incursions is beyond doubt and clearly mirrors both the distribution pattern of copper coins found on the island (revealing a

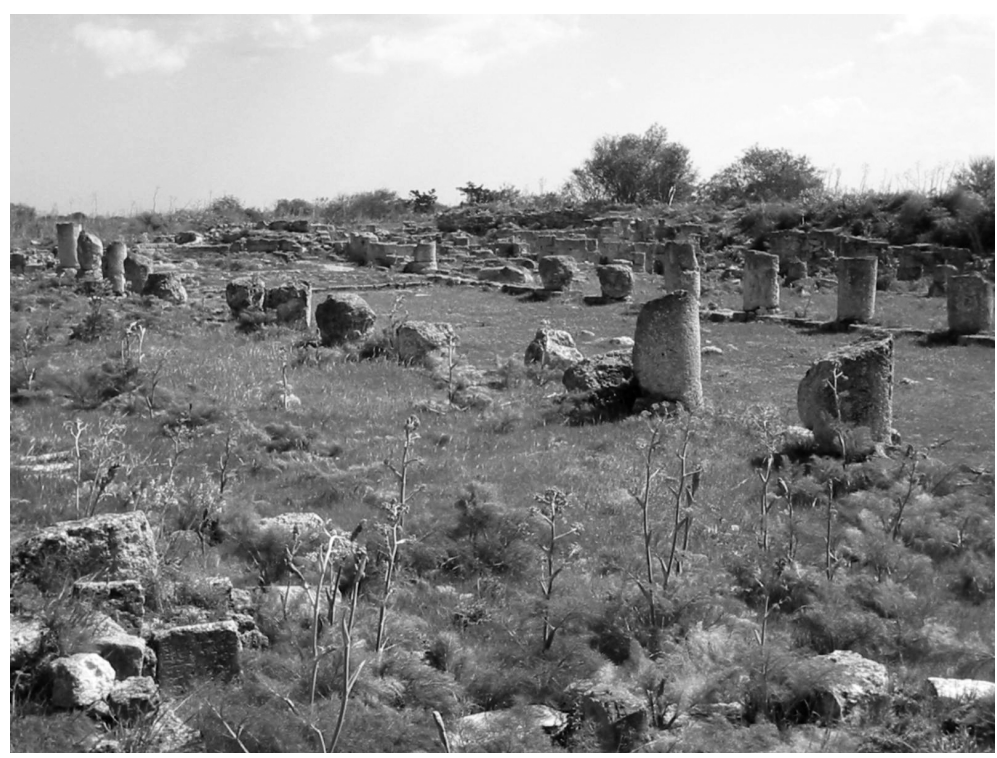

Figure 4.1 Salamis-Constantia: Ruins of the Basilica of Saint Epiphanios 
surge in the year preceding the siege of Constantinople) and the role that Cyprus played in staging the naval raids the Byzantine maritime corps of the Mardaites conducted against the coast of northern Syria in the second half of 670s. ${ }^{110}$ However, this does imply that the urban fabric and social structures were heavily militarized or reduced, and therefore limited to the intra-moenia areas. The date of the erection of the wall has proved quite difficult to establish, because excavations have mostly been conducted well before the events of 1974 (as at Agios Philon, Soloi, and Salamis-Constantia) and, therefore, their conclusions are based on out-of-date considerations of ceramic and numismatic evidence. ${ }^{111}$ Moreover, as in the case of Salamis-Constantia, many excavations have never been properly published, leaving scholars to play with a large time span stretching from the Persian War to the early eighth century. ${ }^{12}$

It is difficult to ascertain the true political status of the island in the period between the last Arab raid in 653 and the ratification of the 686-88 treaty between Caliph 'Abd al-Mālik and Justinian II, as we can rely only on very scarce references in the sources. However, we can catch a glimpse of life in Cyprus in the second half of the seventh century thanks to the contemporary Life of Saint Spyridon of Tremithos written by Theodore of Paphos. ${ }^{113}$ Saint Spyridon is one of the most famous Cypriot saints because he is included in the list of signatures to the Council of Sardica in 343 CE as bishop of Tremithos and is also mentioned by Sozomen as a famous miracle worker whose fame (and later relics) turned the city of Tremithos into an important pilgrimage site. ${ }^{114}$ Theodore, who in all probability was a monk in a monastery not far away from Kourion, read his work on the occasion of the famous panegyris (trade fair) held in honour of the saint in Tremithos in $656 .{ }^{115}$ The episode inevitably reminds us of a similar event that occurred later in Ephesus, where, according to Theophanes's Chronicle, the local fair dedicated to Saint John the Theologian was worth 100 pounds of gold. Indeed, there is evidence for other such periodic (often annual) markets all across the Byzantine Empire, usually taking place on the feast day of a city's patron saint and catering to regional, interregional, and even international trade. ${ }^{116}$ The panegyris of Tremithos, however, holds special importance not only because it was the stage of Theodore's speech, but also because the latter was read in front of important guests such as Sergius, archbishop of Constantia, Paul, archbishop of Crete (on his way from Egypt to Constantinople), Theodore, bishop of Trimithos, Theodore bishop of Kition, and Eusebius, bishop of Lapethos. ${ }^{117}$

The presence of the Cretan archbishop, in particular, shows that even in the aftermath of the decisive Battle of the Masts $(655 \mathrm{CE})$, which saw the Byzantine fleet defeated by the Umayyad navy, Mediterranean sea-lanes continued to link the Islamic Levant with the Byzantine heartland. ${ }^{118}$ One can only guess why Paul might have been visiting Egypt, but it is clear that by passing through Cyprus he was not only following the same routes as the former annona ships, but he was also making the same land journey as goods, for Egyptian fine wares and amphorae kept being exported to Cyprus well into the eighth century. The journey finds further confirmation in the sigillographic evidence, such 
as the lead seals of Damianos, Archbishop of Cyprus, from the mid-eighth century. The seals of Damianos point to the contacts between Cyprus and Crete through their peculiar iconography. ${ }^{119}$

Nevertheless, one can pair the above-mentioned hagiographical source with the inscriptions found in the atrium of the basilica at Soloi documenting a reconstruction of the building following the raids and an earthquake:

In the seventh year of the edict, of Diocletian occurred by reasons of our sins an attack against the island and many were killed and others were carried off as prisoners, around 120,000; again the following year the island suffered another, worse attack, during which were slaughtered more than the previous time and were taken away thousands more, around fifty ... and the basilica and all the bishop's household ... and other notables ... and in other places of the island there occurred the accursed earthquake ... so as to demolish the holy church. He raised up in zealousness, John the holy ... he built those buildings which had fallen and he erected them and he roofed them and he adorned them and completed". 120

Indeed, we should take the information provided by the two inscriptions with the proverbial pinch of salt, especially in light of a study of the floors of the church (covered in mosaics and opus sectile), which has pointed out that there is no way we can associate the destructions that occurred in the basilica with the Arab raids. ${ }^{121}$ The exaggerated figures given by the inscriptions seem to echo the details provided by Christian literary sources referring to the party of Arab raiders: according to Theophanes, Mu'āwiya attacked Cyprus with 1,700 ships, and if Dionysius of Tel-Mahre did not give any number, he nevertheless conceded that there were so many long ships and smaller boats that the sea was turned into a floating forest. ${ }^{122}$

Curiously the Arab chronicles reporting on the raids offer a less catastrophic account and less resounding figures than the Christian sources. Only al-Kūfî refers to the number of ships that took part in the first raid (adding up to a less staggering total of 220$){ }^{123}$ and when al-Balādhurī mentions the 500 ships that transported troops to Cyprus during the second expedition against the island, he also states that Mu'äwiya quickly forced the Cypriots to capitulate, sent to the island some Arab colonists, and erected a number of mosques. ${ }^{124}$ This is not to downplay the disruptive effects of the raids upon the social and economic life of the island but to provide a more balanced approach to the extent and long-term consequences of the incursions. For instance, as Beihammer has argued convincingly, the effects could be traced in the eighth-century tradition partially based on authentic information of the seventh century incorporated in the later Arabic chronicles (especially that of al-Balādhurī). ${ }^{125}$

We also know that some Cypriots were taken as captives and enslaved by the invaders. Indeed, a later source - the Questiones et responsiones written by Anastasios of Sinai, a monk who lived and extensively travelled the Levant in 
the late seventh century - states that when visiting some Umayyad state farms around the Dead Sea, the author found out that the workers were all Cypriot slaves. ${ }^{126}$ However, there is still evidence of building activity (not limited to reconstruction, as shown by the eighth-century barrel-vaulted churches built across the island), economic vitality (based on the analysis of ceramic and numismatic evidence), and continuity of Byzantine fiscal and administrative structures (as enhanced by the widespread use of ecclesiastical and civic lead seals well into the eighth century) on Cyprus. ${ }^{127}$ As I will return to these shreds of evidence in much greater detail later, I would like to point out that the course of events on Cyprus may have been less dramatic than depicted by the Christian sources. It may have been more similar to the situation in SyriaPalestine, where Muslims reduced the local cities to obedience more through voluntary surrender and pacts than by acts of violence. ${ }^{128}$

However, we should concede that, as opposed to Syria and Palestine, no real political capitulation took place on Cyprus after the Arab raids of 649 and 653 (at least not one recognized as such by the Constantinopolitan establishment) and that the Byzantine naval power, by then effectively challenged by the Muslim fleet, was still a strong force. Indeed, as Haldon remarks:

The history of seventh-century Syria is a story of continuities and slow transformations in economic respect ... of relative continuity in the institutional order, but of substantial political and ideological shift. ${ }^{129}$

Nevertheless, on Cyprus these shifts can seldom be traced, as the real political status of the island in the period under consideration is not clear. With regard to the Cypriot political status in fact, historiography has traditionally preferred to enhance the origins and the consequences of the already mentioned 686-88 treaty between Caliph 'Abd al-Mālik and Emperor Justinian II, supposedly prompting the military and political neutralization of the island or its transformation into a no man's land, where the surviving structures of power were in the hands of the ecclesiastical hierarchies promoting a de facto independence of the island. ${ }^{130}$ Partial exceptions to the trend can be found in the in the work of Christides, Mansouri, and, partially, Cameron and Beihammer. The latter two focus less on the origins of the final treaty than on the diplomatic and military standoff between the Umayyads and the Byzantines during the second half of the seventh century, not merely as presented by the Byzantine and Islamic sources (and by the legal practice and political theories of both sides) ${ }^{131}$ additionally, their contributions have the merit of contextualizing the agreement in the political conditions and military confrontations of the eastern Mediterranean in the mid- to late seventh century.

With the Muslim navy geared up to capture its final goal, Constantinople, the speed of the Muslim military tidal wave increased significantly after Mu'āwiya, the founder of the Umayyad dynasty, became caliph in 661 after having briefly slowed down because of the civil war (fitna) with Al'i's party. ${ }^{132}$ As Jeffreys and Prior effectively summarize: 
Rhodes was again [after a first raid in $652 \mathrm{CE}$ ] assaulted in 667 and was occupied by a garrison and squadron in $673 \ldots$... In 669 the Egyptian fleet sailed to attack Byzantine Africa, although it returned after wintering over in Sicily. [Eventually] in 671-72 two fleets entered the Aegean and wintered at Izmir and in Cilicia and Lycia. ${ }^{133}$

Cyprus was affected by the chain of events leading to the siege of Constantinople (674-78). It is unclear if Cyprus was invaded again in 670 and certainly there is no evidence that the island remained fully under Arab control until 686. ${ }^{134}$ Instead, it has been argued convincingly that Byzantine bronze coins saw a peak in their circulation across the island in the years 666-68 - a clear indication that troops were quartered on the island when the Umayyads started their "final" advance towards Constantinople. Numismatic evidence also allows us to trace the importance of Cyprus in the aftermath of the siege, which ended when the Arab fleet was turned back and eventually almost completely destroyed by a wintry storm in the area of Sullayon. ${ }^{135}$

With the Muslim navy crippled, the coasts of Syria (and Palestine) were open to Byzantine counterattacks staged by the special corps of the Mardaites (Christian mountaineers of northern Syria, known to the Arabs as jarajima). ${ }^{136}$ That the Mardaites' incursions may have been launched from Cyprus is reflected in the so-called countermarked copper coins dated to the reign of Constantine IV (668-85), which would indicate that the island continued to play a strategic role in the military operations the Byzantines were conducting in the Levant against the Arabs. ${ }^{137}$ This role was appreciated by the Caliphate as well, for al-Balādhurī refers to a group of Muslims from Ba'albek (a city known in the classical period as Heliopolis and located in the Beq'a valley astride the road leading from Homs to Damascus): they were transplanted to Cyprus in the aftermath of the second raid and accommodated in a city built for them. ${ }^{138}$ Therefore, it should come as no surprise that these men were called back by the successor of Mu'āwiya, his son Yazid, abiding by the agreement his predecessor had signed with Constantine IV in 677/8 (which, however, did not mention Cyprus). ${ }^{139}$ With regard to the Muslim colonists transplanted to Cyprus (whose function remains unclear, as al-Balādhurī calls them troops and refers to the special stipends assigned to them, hinting at a possible military role) it is interesting that the numismatic evidence may confirm their effective presence on the island. In fact, the analysis of the mintmark of the so-called Arab-Byzantine coins yielded by excavations at Paphos, Kourion, and SalamisConstantia has revealed that some specimens were struck at Ba'albek and further countermarked in Arabic, possibly to reassert their fiscal validity as they were circulated in Cyprus. ${ }^{140}$

The very fact that coins were issued in both the Caliphate and the Empire, yet countermarked to facilitate their circulation and acceptance throughout Cyprus, should point to the existence of peculiar Muslim and Byzantine fiscal structures operating across the island. It is, however, impossible to surmise the complexities of collecting and payment mechanisms and the patterns of 
central control on the part of both polities. However, as the literary sources and sigillographic material seem to confirm, Muslim tax-paying structures must have disappeared when the troops and the colonists were repatriated and the Caliphate plunged into the second fitna following the death of Mu'âwiya's son and successor, Yazid. The Islamic lead seals unearthed on Cyprus cannot be used to precisely date or define the Muslim presence in Cyprus because they cannot be firmly linked to a settlement on the island (although some of them come from Paphos). Nevertheless, they present us with peculiarities (like the word Qubrus) that may lead us to think of unique forms of long-term socio-political coexistence that also left traces in literary evidence, as in the passage from the Life of Constantine the Jew. ${ }^{141}$

In a similar vein, one could refer to the terms of the treaty of $686-88$, which partially stemmed from the inability of the Caliphate to forestall the Byzantine maritime offensives in the eastern Mediterranean, but was mainly brought about by the internal civil war in which the rebel Ibn Zubayr rose up against the Umayyads. ${ }^{142}$ According to Theophanes:

In this year [685-86] Abimelech sent emissaries to Justinian to ratify the peace which was concluded on these terms: that the Emperor should remove the host of Mardaites from Lebanon and prevent their incursions; that Abimelech would give to the Romans every day 1,000 gold pieces, a horse, and a slave, and that they would share in equal part the tax revenues of Cyprus, Armenia, and Iberia. The treaty was later ratified by the Magistrianos Paul sent to Abimelech. ${ }^{143}$

As a consequence of the treaty the Mardaites ceased to be a thorn in the side of the Caliphate, but one must also admit that no reference was made to the neutralization of the island, which is hinted at only by later sources. ${ }^{144}$ Moreover, it is highly uncertain whether the partition of tax revenues or condominium meant anything much in practice. In truth, according to Mansouri and Christides the very term condominium is misleading, for it is a Latin word and therefore, never used in the sources. In fact, there was no Islamic power or hybrid regime on the island; Constantine Porphyrogennetos later noted that the Arabs did not possess Cyprus but simply received taxes from it. ${ }^{145}$

The Arabic and the Byzantine sources are discordant when interpreting the treaty. On the one hand, the long digressions in the narrative of the ninth-century chronicles of Ibn Sallām (one of the most ancient sources on the military contacts between the Byzantines and the Muslims) and al-Balādhurī ${ }^{146}$ present us with the well-informed opinions of different Arab jurists who were summoned by the Abbasid governor of the so-called frontier-cities district (thughür). To them the treaty clearly involved three independent parties: the Byzantines, the Muslims, and the tributary Cypriots who had contracted an 'Ahd (a form of nominal truce also found in the description of the status of the Balearics at the beginning of the eighth century). ${ }^{147}$ In the words of Yahiya b. Hamza, one of the exegetes: 
The Cypriots were not protected by the Muslims and, therefore, the Islamic laws did not apply to them. They are not protégés (dhimmi) but tributaries (ahlu fidytin). They must abstain from fighting, and the Arabs must honour the agreement as long as they do the same and accept their excuses as long as they pay the tribute. ${ }^{148}$

Such a notion was clearly never accepted by the Byzantines, who decided to breach the treaty few years later in 691-92, when Justinian II decided not to accept coins minted by Caliph 'Abd al-Mālik and moved part of the population of the island to the newly built city of Nea Justinianoupolis on the Hellespont. ${ }^{149}$ When few years later 'Abd al-Mālik passed away and left the Caliphate in the hands of his son al-Walīd, the latter responded by expelling many Cypriots to Syria, only allowing them to return home when an additional 1,000 dinars was added to their annual tribute. ${ }^{150}$ Justinian II himself gave up on the dream of building his monumental city and repatriated the Cypriots, essentially reverting the island to its former political status, which the sigillographic evidence has helped illuminate. ${ }^{151}$

In fact, the lead seals unearthed on Cyprus and dated to the seventh and eighth centuries reveal that the island remained part of the Byzantine administrative, military, and bureaucratic machinery, further confirmed by the presence of the above-mentioned local magnates boasting high court titles such as illustrioi, spatharioi, and palatine. ${ }^{152}$ With regard to local elites in particular, note that sealing activity, although primarily peculiar to officials, dignitaries and members of the ecclesiastical hierarchy, was not limited to the imperial administrators or bishops and archbishops. In Polis-Arsinoe, excavations have yielded two lead seals that belonged to a woman (probably a member of a local aristocratic family) buried in close proximity to two churches refurbished in the eighth century; according to the excavators the specimens should be interpreted as an indication of status, ecclesiastical connections, and literacy. ${ }^{153}$ The importance of local elites in local political life helps to explain both the resilience of the Cypriot economy (as will be seen later), as they helped to underpin the level of local production and distribution, and their relevance in the Cypriot sociocultural life, as shown by the aforementioned embassy sent from the Constantinopolitan court to the caliph including the three phangoumeneis. Although mentioned by a later source (Constantine Porphyrogennetos's De Administrando Imperio dated to the mid-tenth century), the phangoumeneis can be compared with similar figures mentioned by Arab sources as local representatives in insular territories (like the Balearics) politically under Byzantine rule. $^{154}$

In this respect, local aristocrats assume a paradigmatic importance, as they seem to emerge from this event as cultural brokers, who often humanize stories of intercultural relations, making them more personal and easier to relate to. ${ }^{155}$ Cultural brokers are liminal figures inhabiting two worlds, their very existence addressing the issue of power since they are often caught between two powerful streams. They often are simply identified with translators, but in 
truth they emerge as mediators between cultural and symbolic systems by not only translating, explaining, or enacting operative concepts but also by participating in creative acts that reinvented cultures. Many brokers were drawn from the leadership ranks of their communities because "rules and expectations of a particular context must be clearly understood from the perspective of one culture and problematized from the perspective of the opposite one, to elucidate the challenges of brokerage". ${ }^{156}$ With this in mind, and going back to Cyprus, it is possible to interpret the phangoumeneis's role as complementary with that embodied by more "traditional" and obvious cross-cultural travellers, like the Cypriots pictured in the Acts of the Seventh Ecumenical Council (787) as sailing in two ships to and from Cyprus and Gabala in Syria. ${ }^{157}$ For brokers were not only responsible for facilitating commercial relationships but also for interpreting diplomatic and political concepts between cultures.

By performing these functions, they helped create the infrastructure of the Cypriot middle ground as a historical space. This definition should help us to finally overcome the temptation of labelling Cyprus simply as a socially, culturally, and economically barren outpost along the frontier, a result of two empires' inability to best each other on the battlefield in the transition from Late Antiquity to the early Middle Ages. In other words, by proposing the middle ground as an analytical frame, our inability to trace the precise typology of Byzantine (or Arab) governance structures becomes less problematic, because they can depart from the usual norms. Indeed, as we have seen, the operation of the middle ground must be understood in a peculiar geographical setting where there is a weakness of hierarchical controls on the part of two polities that cannot oust one another by the use of force. What this means in practice is that both the meaning and the extent of social and political relations between two cultures are often negotiated on a local basis by the ruling class. As Robert Browning states:
It is likely that in Cyprus the old civic structure of Late Antiquity survived in which effective power lay in the hands of city notables and the bishops. It is noteworthy that when the Arabs negotiated ... local representatives were always involved. This was not the normal Byzantine diplomatic practice. $^{158}$

One should be aware that we are not sketching an idyllic or peaceful picture of life on the island, for violence is always an option that each political actor can use as a part of continuous and adaptive creative process. One can therefore regard the recurring military expeditions staged by the Muslims against the island in the period under scrutiny as part of the broader political picture across the eastern Mediterranean. ${ }^{159}$ The incursions should be interpreted as integral to the creation of the Cypriot middle ground, which did not simply result from an attempt to find a lowest common denominator between two sides. In truth, as White points out, "violence becomes one of the central concerns of the middle ground [especially] when there is no authority ... 
capable of creating a monopoly on violence or establishing order". ${ }^{160}$ In this way, one is encouraged to focus on the inability of both sides to gain their ends through force rather than on the supposed endless struggle to annihilate the enemy. ${ }^{161}$

As Beihammer effectively summarizes, confrontational episodes could range from simply shows of force (like the brief raid staged in 726 by the Umayyad Caliph Hisham), to deliberate and grand expeditions intended to increase the Muslim influence on the island by taking advantage of a momentous disarray in the opposite camp, such as the coup attempted by Artavasdos in 742/43, which triggered an incursion against the island and supposedly forced the Cypriots to choose whether to migrate to the land of the Rums or to the Dar al-Islam. ${ }^{162}$ They could also stem from the efforts on the part of both Muslim and Byzantine central authorities to implement control over the border. On the Arab side, such an effort was staged in 805-6, when the Abbasid caliph Harun al-Rashid, in light of a massive reorganization of the borders of the Caliphate, sent the navy to ravage Cyprus because the local inhabitants had violated the peace treaty. ${ }^{163}$ On the Byzantine side, according to Constantine Porphyrogennetos, a similar reorganization was staged during the reign of Basil I (867-86), when Cyprus was supposedly raised to the status of a theme for seven years. ${ }^{164}$ Often depicted by both sides as a consequence of supposed breaches of the original treaty, these military efforts failed and always concluded with the return to the status quo ante. ${ }^{165}$

Indeed, the lack of proper coercive military, political, and even religious force on the part of the central authorities lay at the basis of the very idea of a middle ground. In this way, one can fully appreciate the importance of the military, civic, and also religious Cypriot elite in their often-conflicting capacities as representatives of central authorities and leaders of local communities in building the middle ground. This does not imply that they could not pay a heavy price for their role: a Cypriot archbishop was captured during the 805 raid and transferred to al-Raqqa along with 16,000 compatriots. He was later ransomed for 2,000 dinars. ${ }^{166}$ Nevertheless, we can also document (although in a later period) a Cypriot archbishop performing similar functions to the phangoumeneis: in the late ninth and early tenth century, the bishop of Kythrea headed a Byzantine mission to Baghdad to obtain the release of some Cypriots taken prisoner during an Arab raid. ${ }^{167}$

With this in mind, it is possible to interpret the role played by the phangoumeneis and the religious authorities as germane to that of more "traditional" cross-cultural travellers. As White reminds us: "the middle ground exists on two distinct levels, as a product of diplomatic relations between distinct people and a product of everyday life". ${ }^{168}$ We could mention, for instance, the Jewish slave who escaped from "Saracen Syria" and settled at Amathos as a convert in the late seventh century, or the monks and laymen who left SyriaPalestine in face of a wave of Arab persecution in $813 .{ }^{169}$ Further examples include Anastasios Sinaite, a Cypriot monk who in the early eighth century travelled considerable distances in Egypt and Syria-Palestine and visited his 
compatriots held as captives at an Umayyad state farm on the Dead Sea; renegades such as Lacharobaphos, an eminent member of a Palestinian Christian community, who landed in Cyprus only to be apprehended and repatriated; and Cypriots (possibly merchants) pictured in the Acts of the Seventh Ecumenical Council (787) as sailing in two ships to and from Cyprus and Gabala, in Syria. ${ }^{170}$ To these one could even add the aniconic decorative motifs found in the eighth-century churches of Agia Varvara or Agia Paraskevi, which, although probably not directly imported from Syria-Palestine as Stewart advocates, nevertheless are witness to a common artistic language shared by both sides. ${ }^{171}$

The repeated reference to Syria and Palestine is relevant here because in that region Christian and Muslim communities (called dhimmis) lived side by side. ${ }^{172}$ Indeed, in Cyprus we can document the presence of a Muslim minority through literary and material sources. Muslim tombstones have been found in Paphos dating to the seventh and eighth centuries, Kufic inscriptions were found on a column at the basilica of Kourion (late seventh century) as well as on some Islamic amphorae, Arab-Byzantine coins and Islamic lead seals circulated on the island, and eventually (leaving aside the above-mentioned episode involving the common use of a Cypriot church on the part of Muslims and Christians as reported in the Life of Saint Constantine the Jew), in an early tenth-century letter written by the Constantinopolitan Patriarch Nicholas Mystikos, we find complaints about the assassination of Saracens on the island by the Byzantine commander Himerius, which triggered a bloody retaliation against the Cypriot Christian population by Caliph al-Muqtadir. ${ }^{173}$ All this evidence could be regarded as the result of constant diplomatic, political, and commercial encounters between the two cultures.

Indeed, a similar analytical framework, although in a different geographical context, has been proposed by Vionis:

The understanding of daily affairs, material culture, and the arts in the Aegean rural provinces in attempt to assess the notion of convivencia or cultural exchange and coexistence. [This not to discount violence but rather to] investigate the degree to which a specific group retains its own identity and characteristics but at the same time it accommodates "qualities" from its counterparts. ${ }^{174}$

This allows him to stress the intense encounters of people (de facto mediators and creators), which reveal Arab influences in the decorative non-figural church paintings on the island of Naxos (reminding us of Agia Varvara and Agia Paraskevi). ${ }^{175}$ Moving across the geographical and historical horizons of two powers, these social actors also facilitated a process of communication a continuous flow of people and goods across boundaries. ${ }^{176}$ Back on Cyprus, this is enhanced both by travellers and pilgrims (such as Willibald in the eighth century and Epiphanios the Monk and Peter of Atroa in early ninth century ${ }^{177}$ ) who visited Cyprus on their way to the Holy Land (by then under 
Muslim rule), and by the donors of the Cypriot wood sent to help rebuild the Church of the Holy Sepulchre in Jerusalem in the early ninth century. ${ }^{178}$ With regard to the latter episode, it is also interesting to note that al-Balādhurī and (partially) al-Muqaddasī refer to mule-loads of gold and silver dispatched from Cyprus together with Byzantine artists, probably from Constantinople, to be used in the erection of the Great Mosque of Damascus in the early eighth century. ${ }^{179}$

In practice, we can think of a diverse social and cultural fabric emerging in Cyprus. It mirrored both the Cypriot political structures, which were only loosely pertinent to the "usual" military categories and juridical formulas used by both sides (for example the Byzantine thematic organization or the Islamic "dhimmitude") and the economic vitality of the Cypriot elites in terms of the persistence of the levels of demand and production they underpinned. ${ }^{180}$ This will be discussed in detail in the next chapters, in which material culture will be used to show, for instance, how much Islamic pottery imported from Egypt or Syria circulated in early medieval Cyprus and how many locally made Cypriot wares were exported to the Levant or to document the eighth-century church building activity in urban and rural contexts. All of these indicators point to consistent levels of wealth and acts of patronage on the part of local secular or religious elites while disproving the idea of a demographic collapse following the Arab raids. Instead, material sources (seals in particular) will be used in the last section of this chapter to shed some light on the actual structure of socio-political power on the island and the role of local elites in it, for it is clear that Cyprus was constantly regarded as an important naval stronghold by the Constantinopolitan court.

Lounghis, Pryor, and Jeffreys state that upon the second failed siege of Constantinople by the Arab fleet (714-18) and the successive attempted coup against Emperor Leo III in 719, the Byzantine court decided to dissolve the central fleet of karabisianoi. ${ }^{181}$ It is not clear if the karabisianoi fleet had been created as a corollary to the Quaestura Exercitus of Justinian - as Lounghis asserts - or as a frontline defence against the impending maritime threat brought about by Mu'āwiya's fleet in 650s. ${ }^{182}$ Nevertheless, the central fleet was replaced by two new naval commands: an imperial fleet (basilikon ploimon) based in Constantinople and a thematic fleet of the kibyrrhaiotai, whose strategos was based at Antalya along the southern coast of Asia Minor (and just few miles away from Cyprus). ${ }^{183}$ It is, however, not clear how Cyprus fitted in the reorganization of the fleet devised by the Constantinopolitan court and what the relationship was between the local authorities and the strategos sitting in Antalya, for the island was not officially included in the Kibyrreothic theme.

Indeed, we know from Theophanes and Anastasius Bibliothecarius (writing in the late ninth century) that Cypriot waters were considered to be the exclusive hunting grounds of the kibyrrhaiotai as showed by the Byzantine naval victory off the southern coast of Asia Minor at Keramea. ${ }^{184}$ The Taktika of Leo VI explicitly mentions that the Byzantine naval commanders should 
take control of Cyprus before any "barbarian" ship could gather off the island. ${ }^{185}$ That Cyprus (or at least its waters) was regarded as the backyard of the kibyrrhaiotai is also clear from the sigillographic evidence of eighth-century seals belonging to the strategoi Nikephoros and Petros of the Kybirrhaiotai paired with those belonging to drouggarioi (naval commanders), ex prosopou (seconds in command), and stratelatai found at Larnaca, Amathos, Polis-Arsinoe, Kyrenia, and Lapethos. ${ }^{186}$

On the other hand, apart from the aforementioned episode regarding the short-lived theme of Cyprus - in truth only referred to by Constantine Porphyrogennetos - it is possible to infer a politically fluid situation on the island mirroring the seals. These show the continuity of political authority in the Byzantine administration although germane to a pragmatic exercise of fiscal power on the part of the local elites. The seals bearing functions such as eparchs, dioketai, and archontes are to be stressed here, because the latter, according to Metcalf and Lilie, was supposedly at the head of the Cypriot civic administration from the eighth to the tenth century, although with a partial military role. ${ }^{187}$ As Lilie stresses, the archontes (such as one Leontios, whose seal has been dated to the late seventh to early eighth century) were never "regular" Byzantine officers, as the title was conferred to the members of local aristocratic families acting as governmental representatives on other Byzantine islands like Crete, Sardinia, the Balearics, and Malta. ${ }^{188}$ The same applies to the eparchs revealed by the sigillographic evidence as notables from the leading Cypriot families with roles in the local governance structures. These included the official in charge of the fiscal exaction (dioketai) - possibly through a mixed system of taxation in money and kind - clearly proving that Cyprus was not granted a semi-independent status but was fully integrated with the provincial Byzantine administration, which relied upon local aristocrats. ${ }^{189}$

In this light, it would be easy to conclude that the Byzantines simply regarded Cyprus as a military, fiscal, and religious outpost at the periphery of the Empire and the Muslim Caliphate; in fact, material evidence and a comparison with other islands show us that the political, social, and economic reality on the island was far more complex. In particular, we should consider that on some Mediterranean islands under Byzantine rule (such as Sicily, Malta, Crete, and the Balearics) we can trace a sort of adaptation in the structures of governance common to territories that were integrated into the Empire's culture and religion, though not located in the so-called Byzantine heartland. Moreover, we can fully grasp how the local elites at times adjusted their loyalties to survive the various difficulties facing them, such as during the Arab incursions or local revolts against the central power (such as the one staged in 826 by Euphemios, the strategos of Sicily, or the call for Carolingian help by the inhabitants of the Balearics vis-à-vis the incursions of Andalusian pirates). ${ }^{190}$

Consider Sicily, for example, which maintained a stable economy primarily based upon its specialization in grain production, which became essential to Constantinople after the break of the Egyptian tax spine in the mid-seventh 
century, and its role in the shipping routes linking the Tyrrhenian and Aegean seas via the Ionian Sea. ${ }^{191}$ Unlike Cyprus, Sicily did become a theme in the late seventh century and this event is clearly reflected in the fineness of gold coins and the tapering bronze coins issued by the Syracuse mint. ${ }^{192}$ This in turn could point to the increasing regionalization and self-sufficiency of Sicilian finances and in particular to the modification of the Byzantine methods of fiscal apportionment and exaction. ${ }^{193}$ As already mentioned, however, one should also consider that the rarefaction of monetary emission does not imply a collapse of economic, administrative, and political life. In particular, if we focus on the reform of the Byzantine fiscal structures we may notice that on an island retaining strong links with the capital of the Empire, such as Sicily, this was linked with an increased (and almost exclusive) responsibility of the local landowning elites. ${ }^{194}$ A similar phenomenon can be identified on Cyprus, where, as we have seen, the central role local aristocrats played in political and administrative life is confirmed in the sigillographic and literary evidence and their economic resilience is reflected by ceramics and coins.

It is also interesting to note that a sort of regular correspondence existed between Cyprus and Sicily. An eighth-century seal belonging to Konstantinos, imperial spatharios and strategos of Sicily, and an undated specimen issued by a kommerkiarios of Sicily have been discovered in Cyprus. ${ }^{195}$ Similar shreds of evidence simply do not exist for other islands, particularly for Crete, which was regarded as a strategic hub by the Byzantine fleet and was repeatedly raided by the Arabs from the second half of the seventh to the first quarter of the eighth century. ${ }^{196}$ However, analysis of the available lead seals again points to the peculiar provincial status of Crete within the Byzantine administrative system. Indeed, the structures of local governance seem to move along similar lines as those of Cyprus, for archontes governed the island from the late seventh to the first quarter of the ninth century, when Crete fell to the Andalusian pirates. It is again worth noting that Crete was never elevated to the status of theme, although (again like Cyprus) there was a brief attempt to establish a thematic administration in the mid-ninth century (843), when a large naval operation was staged to recover the island from the Muslims. ${ }^{197}$ The Cretan elites and the local economic infrastructures they underpinned are particularly traceable in the capital of the island, Gortyn, where archaeology testifies to the changing institutions of political governance and increasing control on the socioeconomic dynamics of power by the local elites (for example the seals found belonging to the basilikos spatharios kai archon Kretes dated to the mid-eighth to early ninth century). ${ }^{198}$ The Cretan archontes had judicial, fiscal, military, political, and even commercial functions, the latter attested by another seal struck by an archon paraphylax (a state official overviewing and controlling the market and fiscal activities). ${ }^{199}$

The overarching role of Cretan archontes seems to have remarkable similarities with the trends we have traced in Cyprus, although we should not tone down what Zanini describes as "the processes of economic simplification of the socioeconomic structures, the less-than-complex social hierarchies, and 
the concentration of the ruling class in fewer urban sites". ${ }^{200}$ Rather we should point to the Cretan economy (and therefore the local level of demand on the part of the Cretan lay in the ecclesiastical ruling classes) as having a degree of vitality evidenced, for instance, by the peculiar, highly decorated, locally made painted wares in Gortyn and Pseira, the importance of the local ecclesiastical authorities with the archbishop at their head, and, above all, by the relatively high degree of monetization the island boasted. ${ }^{201}$ It is possible that if the Byzantine Mediterranean islands played complementary though dissimilar roles in the imperial economic grand plan, Crete was slightly overshadowed by Sicily and Cyprus - the former being the main exporter of grain to Constantinople and the latter at the intersection of the capital's regional and interregional networks of exchange. What one should stress here, however, is the pre-eminence of the local aristocracies in the flexible administrative, fiscal, and political structures of governance on islands pertaining to the Byzantine sphere of ecclesiastical and imperial power. Similar developmental trajectories can be traced in Malta and the Balearics from the late seventh to the ninth century.

Malta seems to have suffered a fate similar to that of Cyprus: a lack of attention in the Byzantine sources - as opposed to the medieval Muslim chroniclers and geographers, who pictured the island as fertile and rich which translated into a historiographical perception of an archipelago at the margins of the political, military, and strategic interests of Byzantium. ${ }^{202}$ This long-lasting preconceived approach on the part of contemporary historiographers has been overturned only in the last two decades due to the advances in the archaeology of the Maltese islands. In particular, the analysis of different typologies of ceramics found at different sites of the archipelago has shown that the Byzantines were still interested in sending the navy to the western Mediterranean as late as the ninth century, and that Malta was a strategic stepping stone within the general military defence North Africa (until 698), Sicily, and the Balearics. ${ }^{203}$ However, the volume of trade arriving in Malta was not fully geared to military purposes; eastern Mediterranean goods were also imported to supply local political elites. Indeed, as Brown, Bruno, and Cutajar have remarked, sigillographic evidence conclusively shows that Maltese elites included archontes (based on an eighth- to ninth-century specimen belonging to an archon named Theophilaktos) as well as bishops and other members of the ecclesiastical communities. ${ }^{204}$ As we shall see in Chapter 6, the amount of imported amphorae in Malta, for instance, speaks volumes about commercial vitality, which stemmed both from its strategic position in the central Mediterranean and a degree of autonomous action allowing the local authorities to economically bridge the political gap between Muslim Africa and the "Byzantine Italies". ${ }^{205}$ In this light, it seems that, like in Cyprus, the Maltese elites took an active stance and engaged in trade and political exchanges with the Muslims, proved by Umayyad coins found on the islands and by an eighth- to ninth-century seal belonging to a Niketas, drungarios and archon of Malta, found in Tunisia. ${ }^{206}$ 
Finally, the Balearics also provide us with some analogies to Cyprus. In particular, the consequences of an Arab naval raid in 707, as reported by the later Andalusian historian Ibn al-Qūtiya in his Ta'rikh iftitah al-Andalus. The passage in question has prompted a comparison between the political status of the Balearics and that of Cyprus. ${ }^{207}$ Indeed, rather than bringing about a military occupation or the loss of the (unproved) local independence or, finally, a shared condominium, as some historians have proposed, it seems possible that the raid led to the inclusion of the islands in the Dar-al 'Ahd, the same kind of nominal truce (or pact) the Arab sources refer to when mentioning Cyprus. ${ }^{208}$ Like Cyprus (and Crete and Malta), the Balearics never became part of a formal thematic organization. Nevertheless, they were used by the Byzantines to stage naval raids against the coasts of Visigothic Spain in the late seventh and early eighth century (reminiscent of the contemporary Mardaite maritime expeditions departing from Cyprus). ${ }^{209}$ In other words, as Signes Codoñer remarks, it was only in the early tenth century that Byzantium really gave up on the possession of the Balearic archipelago. ${ }^{210}$ More importantly, there is also a similarity between Cyprus and the Balearics with respect to the character of Byzantine administrative, political, and military structures. In fact, the recent publication of some lead seals found at different sites on Menorca and Majorca (the two major islands composing the Balearic archipelago) allows us to assert that the Balearics remained within the Byzantine political sphere until the early tenth century, when the islands became part of the Umayyad Caliphate of Cordoba. ${ }^{211}$ Particularly relevant are the late seventh- to early eighth-century seals found at the Castle of Santueri in Mallorca, which boast similar titles to the Cypriot specimens previously mentioned, and a mid-eighth-century seal issued by a local archon named Gordio. ${ }^{212}$ The former point to the presence on the islands of at least one apo archon, a middle-ranking dignity in the Byzantine bureaucracy responsible for the collection of local taxes; the latter reveals again the deliberate Byzantine strategy of appointing archontes chosen from among the ranks of the local elites as heads of local administration who enjoyed a great degree of autonomy. ${ }^{213}$

Given all this information, one might be tempted to set Sicily apart from the other islands because it was elevated to the rank of theme while the others were ruled by usually local archons and were therefore more capable of bending the rules, especially when facing a closer threat as did the Balearics or Cyprus. The informality of the rules of the political game is more noticeable in Cyprus because of its size and vicinity to the Umayyad centres of power and the economically lively Syria-Palestine region. The emergence of Cyprus as a middle ground where both sides applied models of equitable exchange and sought cultural congruence could also be interpreted as prompted by its peculiar location and its geomorphological characteristics. The Balearics were simply smaller and too far away from Damascus.

From the comparison with other Byzantine Mediterranean islands it emerges that Cyprus was not simply a quasi-independent outpost from the seventh century onwards. In all probability the island experienced not only 
the substitution of the old ruling class with diverse and multifaceted social groups but also the establishment of a new hierarchical social model - a model shaped by the rise of a new macro-class made of civic, military, and, as will be seen, religious authorities and characterized essentially by the ownership at different levels of locally entrenched social and economic power. ${ }^{214}$ In the absence of explicit and implicit markers like monumental iconography, euergetism, and clothing, in the case of Cyprus one should primarily use lead seals to shed light on the activity of individuals or groups with privileged social and political roles. Moreover, one can propose for the new Cypriot elites (a class to which, evidence suggests, aristocrats like the phangoumeneis belonged) a political reorganization similar to other Mediterranean islands like Sicily, Malta, Crete, or the Balearics, although predicated upon different administrative and economic lines.

The evidence and the comparative analysis proposed in this section allow us to propose a rather more complex and truly cangiante sociocultural and economic model. The implementation of autonomous political and economic initiatives on the part of the local ruling class clearly did not impinge on the source of their political legitimacy and their cultural identity. ${ }^{215}$ The strength of the Constantinopolitan central hierarchies and their politically and socially more prestigious and remunerative posts was hard to countermand for insular and city-based aristocrats. Nevertheless, the material and written evidence presented above, paired with the economic trends presented in Chapter 6, shed some light on the fact that aristocracies in Cyprus morphed into more informal elites preserving an urban lifestyle, who were absorbed into local state hierarchies (civic and military, as shown by sigillographic evidence) and probably at least partially retained their lands. Moreover, as the numismatic evidence shows the persistence of some amount of liquidity among social elites, it also demonstrates the capability of the central state to demand, collect, and redistribute resources through taxation. In other words, the Byzantine fiscal machinery - that is, the lower and high-ranking civil and fiscal officials who issued some of the seals found on the island - continued to perform their functions on Cyprus in the eighth century and later, along with the military arms of the Byzantine administrative apparatus.

But in all probability, the state and local elites were not the only important figures that shaped the Cypriot social, political, and economic life. As Leslie Brubaker and John Haldon have observed, when examining the social and economic milieu of any Byzantine province one should always consider the activities of members of the local autocephalic church. ${ }^{216}$ Therefore, I will now illustrate the importance of the local Church in shaping the social, cultural, political, and economic trajectories of the Cypriot transition. This should also help us to shed some light on the ninth and (partially) tenth centuries, a period not covered in this book, but to which I will return in Chapter 7. Indeed, there is evidence pointing not only to a continuation of the peculiar social, political and economic status quo but also of the ecclesiastical structures. In this regard, a brief overview of the Cypriot Church is essential not only 
because in Cyprus the monks and clergy are more visible in the scant primary sources but also to reassess the conclusions of traditional historiography, which has always treated the ecclesiastical hierarchies as the only keystone in supporting a sense of Cypriot identity and the coherence of the local social and political fabric. This not to belittle the pastoral power of the Cypriot bishops and archbishops or to deny that they were central to the survival of urban centres as political and administrative foci, but rather to stress the role of the Church as complementary to that of local landowning magnates in supporting the resilience of the Cypriot economy and underpinning the local levels of production, distribution, and consumption of goods both in rural and urban contexts in the period under scrutiny and even beyond.

\section{The power of the Cypriot Church}

Reconstructing the history of the Cypriot Church is not a simple task. ${ }^{217}$ On the one hand, one can barely escape the centrality of the island to Christian history, harkening back to the apostolic age when Saint Paul and the Apostle Barnabas supposedly landed in Salamis, where the latter was martyred a few years later. ${ }^{218}$ On the other hand, it is difficult to overcome the impression of a rich intellectual and spiritual Christian life as expressed by both the cult of popular saints, such as Saint Hilarion and Saint Epiphanios (among others) as well as the centrality of Cyprus along the pilgrimage routes to and from the Holy Land. ${ }^{219}$ Therefore this section of the chapter will fall into two parts. I will begin by framing the differences between the role of the Cypriot Church (and its leaders) as presented in mainstream historiography and the different model I propose, in which the Church is one of the actors in the construction of seventh- and eighth-century Cypriot society (and the middle ground). I will end by presenting the history of the Cypriot Church as linked to the distinctive political and economic background we can trace in Cyprus in the period under scrutiny and partially beyond.

As previously mentioned, the wealth of the Cypriot Christians is reflected in an astounding number of wooden-roofed basilicas constructed from the fourth to the mid-seventh century in both rural and urban contexts. ${ }^{220}$ There is no need here to dwell upon the issues of architectural and artistic origins, peculiar characteristics, developments, and possible external models of such basilicas, for scholars like Megaw, Papageorghiou, Stewart, Ćurčić, Stylianou, and Papacostas (to quote just a few) have exhaustively dealt with the problem. ${ }^{221}$ One should instead mention that traditional historiography has always preferred to argue for an abrupt destruction and savage pillaging of the basilicas on the part of the Arabs in the mid-seventh century, although natural disasters are also to be blamed for the disappearance of the lavishly decorated basilicas. This interpretative frame has, however, been successfully reassessed, and scholars now prefer to dismiss the supposed midseventh-century rift in favour of a more nuanced picture of subregional diversity. $^{222}$ 
With this caveat in mind, and when analysing the role of the ecclesiastical authorities during the Cypriot transition, one can overcome some stereotypical connotations. First, we must make clear that there is plenty of evidence of churches being rebuilt after being destroyed in the early to mid-seventh century due to the Arab raids or natural disasters. As Stewart has clearly shown, many early Christian buildings went through two different reconstructive phases, the second lasting well into the eighth century, whereas others were replaced by a different typology of churches (the barrel-vaulted basilicas), which departed from the previous ichnographic and constructive schemes. ${ }^{223}$ The second stereotype that must be avoided is the assumption that the rebuilding campaign stemmed exclusively from the role played by the local bishops and archbishop in the political and social life of seventh- to ninth-century Cyprus. ${ }^{224}$ Often this role has been linked with their staunch iconophilia, which endured even the most difficult tests, such as the heart-breaking arrival on the island of a group of exiled iconodule monks and nuns blinded by the strategos of the Trakesian theme, Michael Lachanodrakon, in 769/70. ${ }^{225}$

One can safely assume that the Cypriot Church continued to be one of the major landowners of the island while also implementing its wealth through donations like that bequeathed to the archbishopric of SalamisConstantia by the early seventh-century argentarios Philentolos. ${ }^{226}$ Donations allowed the local clergy to rise to the status of important urban patrons, as shown by the aforementioned inscriptions commemorating the archbishops involved in the repairing of the aqueduct supplying the capital. ${ }^{227}$ One can also infer from the episcopal lists and, above all, the sigillographic evidence that the ecclesiastical hierarchy was central in keeping Cypriot society urban. In particular, as Dikigoropoulos and Metcalf have showed, it is possible to interrelate the few specimens struck by Cypriot bishops and archbishops from the late seventh to the early ninth century with other written and material evidence to reconstruct a relatively reliable chronotaxis for some Cypriot urban centres. ${ }^{228}$ Here, however, one should not forget that tracing a relatively continuous occupation of local bishopric seats is simply not possible, not only because seals have often been collected without documenting their provenance but also due to the lack of post-1974 archaeological excavations in many of the cities where more continuity would be expected, such as Soloi, Kyrenia, Lapethos, Carpasia, and, above all, Salamis-Constantia. ${ }^{229}$

In fact, the recently published results of excavations at Polis-Arsinoe have demonstrated the vitality of an urban centre for which supposedly very scanty evidence datable to the eighth to tenth century existed. ${ }^{230}$ Such a conclusion mainly relied on the lack of any ecclesiastical seals after the late seventh century. Instead, as will be seen in detail in Chapter 6, an economically vital eighthcentury urban fabric - mainly focused around two ecclesiastical buildings has come to light, together with seals belonging to private individuals and to ecclesiastical authorities like the early to mid-eighth-century specimen belonging to Damianos, Archbishop of Cyprus. ${ }^{231}$ 
The third stereotype has to do with the aforementioned image of selfsufficiency, theological orthodoxy, and independence from central political authorities projected by modern historiography onto the Cypriot clergy as ruling over a semirural island that retained a righteous and often courageous conservatism in religious affairs (apparent in the case of Iconoclasm). One needs look no further than the previously mentioned seal of Archbishop Damianos to prove this theory false. In fact, as three more of seals of Damianos have also been discovered at Kourion and Salamis-Constantia, one can easily conclude that in the eighth-century correspondence was exchanged among church officials across the island and even beyond its coasts, as one specimen belonging to Damianos has been found in Lebanon. ${ }^{232}$ Moreover, these seals were produced by a professional engraver, for they resemble in their elegant design and style contemporary specimens issued by the eighth-century metropolitan Andrew of Crete. ${ }^{233}$ This may hint at the persistence of a multidimensional (political and ecclesiastical) relationship between Cyprus and the other islands of the Byzantine Mediterranean, as shown by the presence of the Cretan archbishop in Trimithos in 655 and the kommerkiarioi and strategoi of Sicily.

Indeed, the letters sealed and posted by Damianos to Lebanon were not exceptional, for lead seals belonging to the bishop of the little island of Aradus-Arwād (off the Syrian coast) and the metropolitan of Tyre have also been found in Cyprus (all having the second half of the seventh century as terminus post quem). ${ }^{234}$ In this light, one can propose a role for the ecclesiastical authorities as mediators and real contributors to the shaping of the Cypriot middle ground. Bishops and the archbishop complemented the political authorities, rather than acting as an alternative to them, and other social actors in helping to retain a network of sound ties with the Muslim Levant and, in particular, with the local Christian religious communities. It is not by chance that one of the few shreds of literary evidence concerning how these ties actually worked on the ground comes to us in one of the most official documents produced by the Constantinopolitan Church: the Acts of the Seventh Ecumenical Council, where it was reported by the Archbishop of Cyprus, Constantine, that in the eighth century Cypriots sailed to and from Gabala in Syria. ${ }^{235}$ The casual mention of such regular journeys in an official speech during the Council attests that for a local it was a natural occurrence, almost in the same way that witnessing Cypriot Muslims and Christians praying in the same building was considered normal, but was more of a surprise to a foreigner like Saint Constantine the Jew. ${ }^{236}$

Therefore, it would be reductive to describe the role of local clergy and the Cypriot archbishopric simply as custodians of Orthodoxy after the internal heroic strife against the Iconoclasts, or as a bulwark against the threat of the Muslim Caliphates, or finally as solely presiding over few semirural communities. Instead, there is evidence of a fertile ground of complex political, economic, social, religious, and cultural urban-oriented relationships both within and beyond the coasts of Cyprus in which the Church played an important but far from sole or dominant role. 
Moving to the second half of this section, I would like to go back to the trip Saint Paul and the Apostle Barnabas embarked upon to get to Cyprus. ${ }^{237}$ The apocryphal Acts of Saint Barnabas written immediately after the Council of Ephesus in the mid-fifth century present us with a description of the journey according to which, rather than heading directly to the island from Laodikea, the party stopped along the Isaurian coast, endured a storm on the island of Pythousa, sailed to Anemurium, and eventually landed on Cyprus, from which they later moved to Alexandria. ${ }^{238}$ If we use the fictional travel as a benchmark against which to measure the changes in Cyprus's role within the routes and rhythms of eastern Mediterranean pilgrimages we may be surprised to notice that similar travel infrastructures to those described in the fifth-century Acts were in place in the seventh and eighth century and even beyond. Pilgrims' logs equally describe Cyprus either as the last stop or a stepping stone in long-distance travels to the Holy Land. They include Antoninus Placentinus in the sixth century; ${ }^{239}$ the Anglo-Saxon Willibald, who travelled at the beginning of the eighth century from England to the Holy Land via Paphos and Constantia; ${ }^{240}$ Anastasius Sinaite, a monk who left Cyprus to travel extensively in Syria, Palestine, and Egypt in the late seventh and early eighth century; ${ }^{241}$ Epiphanios the Monk, who journeyed from Cyprus to Tyre in the early eighth or early ninth century; ${ }^{242}$ and Peter of Atroa, who came from Lydia in the early ninth century to spend ten months visiting some unknown sanctuaries on the island. ${ }^{243}$ To these one should add the fictional journey of two saints: Auxibius (first half of the seventh century) and the previously mentioned Constantine the Jew, who crossed from southern Anatolia. ${ }^{244}$ The latter crossed from Attaleia (modern Antalya on the southern coast of Anatolia), where most travellers heading for Cyprus chose to cross. ${ }^{245}$

Therefore, we can assert that the centrality of Cyprus to the history of Christianity is reflected in the experiences of pilgrims travelling across the eastern Mediterranean throughout the seventh, eighth, and ninth centuries. This should come as less of a surprise if we consider that from its origins the Cypriot Church had strong links with southern Anatolia (for instance, Cypriot pilgrims are recorded at the shrine of Saint Thekla outside Seleucia in the fifth century) and the Levantine coast due to ecclesiastical jurisdiction of the patriarchate of Antioch over the local bishops. ${ }^{246}$ The latter clearly paired with the above-mentioned secular jurisdiction of the Comes Orientis seating in Antioch but eventually came to an end in the early fifth century, after which the Cypriot Church claimed and obtained its independence from the patriarchate of Antioch during the Third Ecumenical Council held in Ephesus in 431, gaining the right to perform their own ordinations of the bishops. ${ }^{247} \mathrm{~A}$ few decades later, Peter the Fuller (Patriarch of Antioch from 461 to 488 , though not continuously) tried to have the decree recanted but had to concede on the question of the autocephaly of the Cypriot church due to the miraculous discovery of the gospel and tomb of Saint Barnabas, who all the later commentators regarded as the apostle who had set the first stone of the Cypriot Church. ${ }^{248}$ 
The confirmed autocephaly of the Cypriot church bolstered the role of Salamis-Constantia as the island's ecclesiastical capital and archiepiscopal see. ${ }^{249}$ It also prompted the building (indeed in the very capital) of three churches that, in all evidence, became three distinct foci of pilgrimage: the monastery of Saint Barnabas outside the city walls; ${ }^{250}$ the new church, which must have been the so-called Campanopetra basilica, an early fifth-century three-aisled basilica that housed an important (but still unknown) relic possibly linked to the mythical stopover of Saint Helen on her way back to the Holy Land; ${ }^{251}$ and the church dedicated to Saint Epiphanios. ${ }^{252}$ Epiphanios, bishop of Salamis in the second half of the fourth century, was an eminent theologian and upon his death he became the second patron saint of the Cypriot Church alongside Barnabas. ${ }^{253}$ The edifice was a seven-aisle basilica supposedly built by the saint himself in place of a previous small church. ${ }^{254}$ This was soon to become the urban cathedral and the final resting place of Epiphanios himself, who was buried there with the special permission of Emperor Arcadius in 403. ${ }^{255}$

The autocephaly of the Cypriot Church was clearly bolstered by the importance of the island as stopover for pilgrims journeying across the eastern Mediterranean. Indeed, Willibald, when visiting Cyprus in the first half of the eighth century on his way to the Holy Land, described its ecclesiastical organization as an island divided into twelve episcoparum parochiae. ${ }^{256}$ Among these were Salamis-Constantia and Paphos, where Willibald spent three days during Easter in $723^{257}$ and where at least one of the two imposing early Christian basilicas was built between the end of the fourth and the early fifth century: the Panagia Limeniotissa and Panagia Chrysopolitissa, the latter functioning as cathedral of the local bishop. ${ }^{258}$ Also included in Willibald's pilgrimage-log are the cities of Soloi (the local church was restored in the second half of the seventh century, according to the two previously discussed inscriptions found in its atrium) and Tremithos, where - during the aforementioned panegyris - the population suddenly recognized, apparently for the first time, that a painting over the main door of the church represented the local patron Saint Spyridon performing a miracle in Alexandria. ${ }^{259}$

Although it is not clear if pockets of paganism persisted on the island (as mentioned by the early seventh-century Life of Saint Tychon [bishop of Amathos] written by Saint John the Almsgiver), one can assume that the doctrinal Byzantine "orthodoxy" of the Council of Chalcedon in 451 (in which four Cypriot bishops took part) did not fully hold sway on sixth- and seventh-century Cyprus. ${ }^{260}$ This is clearly showed by an inscription that infers the presence of a Monophysite bishop (one Philoxenos) in Citium during the 530s. Supposedly his importance and wealth was such that he also financed the construction of some buildings in Salamis-Constantia. ${ }^{261}$ It is worth noting here that a strong Monophysite community is documented on the island during and beyond the period under consideration. ${ }^{262}$

But other non-Chalcedonian churches could also be found on Cyprus. Indeed, Arcadios - the Cypriot Archbishop who in the first half of the seventh century was mentioned by some inscriptions as having restored 
(together with Emperor Heraclius and his predecessor Plutarchos and, possibly, his successor Sergios) the aqueduct Kythrea-Constantia ${ }^{263}$ - was the recipient of a decree issued by Heraclius against the so-called Cypriot Severians in $623{ }^{264}$ In fact, Arcadios's theological and doctrinal inclinations remain unclear, though he is suspected of having supported Monothelism. ${ }^{265} \mathrm{He}$ is mentioned both by Monothelite and Chalcedonian sources, both of which claim his support as opposed to his successor Sergios, who wrote a letter to Pope Theodore I (read at the Lateran Council in 649) and sided with the Roman Church in the final struggle against Monothelism, which was clearly a force to be reckoned with in Cyprus. ${ }^{266}$

However, the increased importance of the Chalcedonian Cypriot archbishopric in the Constantinopolitan ecclesiastical hierarchies and the definitive loss of the Levant to the Arabs have led traditional historiography to overestimate the role played in the local political, economic, and social systems by the Cypriot clergy from the late seventh century throughout the eighth and ninth centuries. In particular, two events have always been regarded as central to the supposed overarching pre-eminence of the Cypriot Church: the socalled transplantation of the local population (in part or en masse) to Nea Justinianoupolis and the island's purported role as bulwark against iconoclasm.

The first episode is relatively obscure, although some archaeological light has been shed on the short-lived city named after its imperial founder Justinian II. ${ }^{267}$ Generally interpreted as a second catastrophe hitting Cyprus in the wake of the Arab raids, in 691-92, according to Theophanes, "Justinian foolishly broke the peace with Abimelech [Caliph "Abd al-Mālik] and strove in his folly to move the population of the island of Cyprus to the Hellespont". ${ }^{268}$ There is, however, no evidence that the whole population of Cyprus was transplanted to Nea Justinianoupolis or that the entire island was deprived of its own clergy. ${ }^{269}$ There is evidence that Justinian II relocated some Cypriots to coastal provinces of naval significance, although the precise reasons behind his resolution remain totally obscured. ${ }^{270}$ However, the Canons of the Quinsext Ecumenical Council held in Constantinople in 691/92 made it clear that the transplantation was at least partially due to the special position of the Cypriot Church within the Patriarchate of Constantinople. ${ }^{271}$ Nevertheless, the migrants were soon returned to Cyprus, although the exact date of their return has been debated and alternatively attributed to Tiberios III or to Justinian II's wish to promote better relations with the Caliphate during his second spell as emperor starting in $705 .{ }^{272}$ Leaving the chronology of the return aside, it is interesting to note that once the migrants returned to the island in the early eighth century, the lead seals of the Archbishop of Cyprus took on a striking new design, which introduced for the very first time the title kyprou. That these have been found at different localities on Cyprus, including SalamisConstantia, Polis-Arsinoe, and Amathos, questions the theory that coastal urban settlements collapsed, as will be seen in Chapter 6 .

The second episode that supposedly shaped the fate of the Cypriot Church was the Iconoclastic controversy, for, as Eglezakis remarks, in this period 
Cyprus should have become a refuge for the victimized, both human beings and icons. ${ }^{273}$ As mentioned in Chapter 1, this conclusion is predicated upon the idea that heresies found no favour in Cyprus for the entire Cypriot population supported the Church, because "in a society like the Cypriot [one] ... religion permeated every aspect of the people's lives, whether social, political, economic, or private". ${ }^{274}$ Traditional historiography has often flirted with the idea of an island boasting an imaginary "permanent iconolatry", which owed to the fact that "Iconoclasm had few if any roots in Cyprus ... from the provincial standpoint it was a policy promulgated from the top-down by emperors (and not responding to the popular sensibilities of the Cypriots) and hurtful to the religious sensibilities of the village people." ${ }^{275}$ This has led scholars to bind the supposed iconophile sympathies of the island's inhabitants to its ruralization (as the urban society of the capital is viewed as more progressive) and to its independence vis-à-vis the central government. The supposed selfgovernment of the iconodule Cypriots, led by the only authority existing on the island finally prompted the final triumph of Orthodoxy, as recognized by the Seventh Ecumenical Council of Nicaea, where the Archbishop of Cyprus, Constantine, played a prominent role. ${ }^{276}$

As already mentioned, recent seminal works on the Iconoclastic period and its sources, both literary and material, have disproved the interpretation traditionally purported by mainstream Cypriot historiography. ${ }^{277}$ This outmoded narrative predicated its conclusions upon the miracles performed by Cypriot icons as reported in Constantine's sermons and (later) a letter written by three eastern patriarchs to Emperor Theophilos in 836. The letter bolsters the idea of a staunchly iconophile island whose orthodoxy is threatened not only by internal but also external enemies; in fact, a passage of the missive describes an icon of the Virgin and child (positioned above the main door of a church in the southern part of the island) that miraculously started bleeding after having been hit by an Arab arrow. ${ }^{278}$ This episode pairs two similar ones included in Constantine's sermons and even led Dikigoropoulos to identify the icon with the now lost sixth-century mosaic of the Panagia Kanakariá at Lythrangomi. ${ }^{279}$ To these miraculous reports one should add the aforementioned passage from the Life of Saint Stephen the Younger in which he identifies Cyprus as a safe haven for iconophiles, ${ }^{280}$ as well as the passage from Theophanes's Chronicle chastising Michael Lachanodrakon, strategos of the Thrakesion theme, for torturing and banishing a group of nuns and monks to Cyprus. ${ }^{281}$

However, all these sources have been recognized as heavily biased and strongly anti-iconoclastic. In particular, the account describing safe areas for iconophiles has been shown to be largely an invention of the author intended to bolster and legitimize the position of monks who had come from those regions after $787 .^{282}$ By the same token, the supposed persecution of the monks and nuns was much less extensive than described by Theophanes in a passage shaped largely by a martyrological topos and a pro-iconophile desire to disqualify the iconoclast. The same partially applies to the sermons read by Constantine before the Ecumenical Council, as they aimed to establish an 


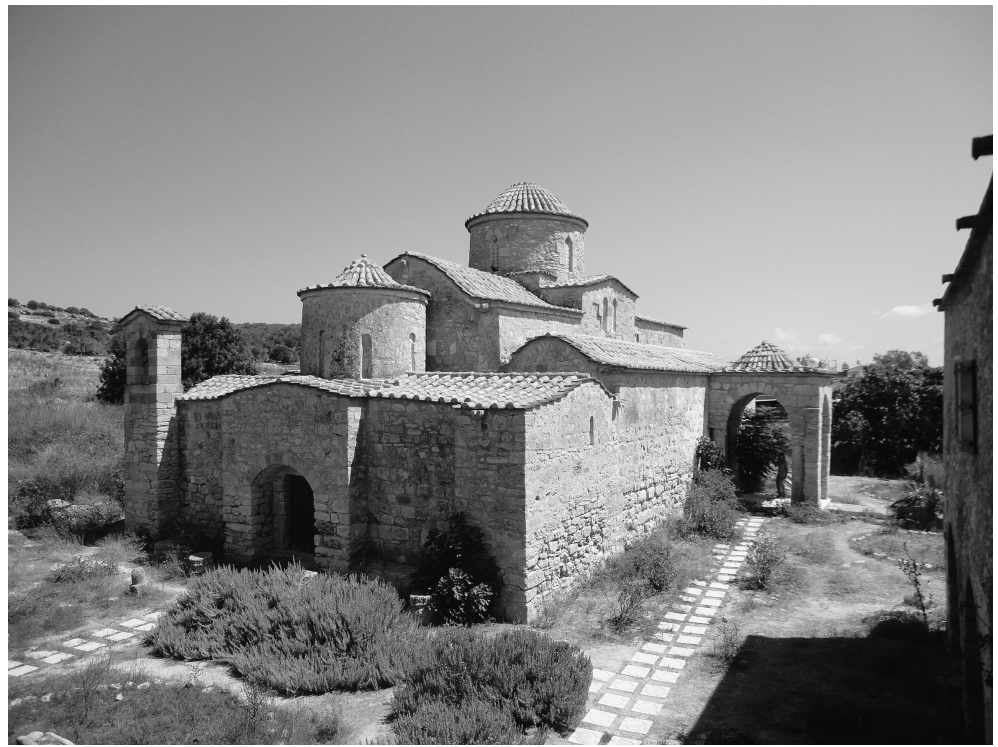

Figure 4.2 Church of Panagia Kanakariá in Lythrangomi

"official" cult of images. ${ }^{283}$ In other words, there is no evidence pointing to the role of Cyprus as a province defending icons and traditional piety outside against the iconoclastic emperors. ${ }^{284}$

In fact, one could stress the role the Cypriot Church played as patron and supporter of artisanal workmanship and artistic production on the island. As abundantly referred to, not only were churches built or refurbished in the late seventh to early ninth century, but their decorative programmes and artistic accoutrements also constituted a major attraction for local and foreign pilgrims. Indeed, ecclesiastical largesse lead to the restoration of the fifth-century basilica Panagia Kanakariá at Lythrangomi, rebuilt in early eighth century and possibly further restored in the mid-ninth century, as showed by a fresco celebrating the Archbishop of Cyprus and the Patriarch of Jerusalem. ${ }^{285}$ The link between the Archbishopric and the Patriarchate was later strengthened by the shipment of fifty Cypriot cedar trunks used to restore the Church of the Holy Sepulchre in the early ninth century. ${ }^{286}$

Churches were built or restored both in rural and relatively peripheral areas, like the Karpas peninsula, as well as in important urban centres. ${ }^{287}$ Remains of eighth-century frescoes and evidence of contemporary reconstruction as a three-aisled basilica have been found in the church dedicated to Saint Herakleidos at Thamassos-Polikitico, a pilgrimage centre from the fourth century onward. ${ }^{288}$ Indeed, as already mentioned, extensive (re)building activity can be documented in the so-called south-west basilica of Amathos and the basilica of Soloi, as well as in the Cathedral of Saint Epiphanios and the Church of Campanopetra in Salamis-Constantia and the Panagia 
Limeniotissa in Paphos, where opus sectile very similar to that in Saint Herakleidos has been documented. ${ }^{289}$ In the same way, in the so-called chapel of Saraya in the Church of Episkopi, Michaelides has documented spolia reused in the opus sectile floor taken from the episcopal basilica at Kourion. ${ }^{290}$ Finally, one should mention two further buildings: the church of Morphou dedicated to Saint Mamas (one of the most revered saints of the island), the excavations of which, though unpublished, documented three superimposed ecclesiastical buildings and a late seventh-century church; ${ }^{291}$ and the church of the Panagia Angeloktistos at Kiti, where an early seventh-century basilica was rebuilt no earlier than the second half of the same century, according to Dikigoropoulos and Stewart. ${ }^{292}$

In this light, we should also consider the centrality of the Church in promoting artisanal activities and sustaining the demand for a skilled labour force. This is apparent in the decorative program of the two barrel-vaulted churches Agia Varvara and Agia Paraskevi. Both dated to the eighth century, these churches boasted aniconic frescoes, indicating the shared influence of Byzantine and Arab style and iconographic motifs. ${ }^{293}$ These churches also reveal similarities with the non-figural decoration of some eighth- and ninth-century Aegean churches, like Agia Kyriaki in Naxos. ${ }^{294}$ Although the frescoed walls of most of the Cypriot barrel-vaulted churches have irreparably faded away, it seems possible to conclude that rather than building invisible walls of sanctity preserving the island from non-Orthodox influxes, churches in Cyprus helped to materialize the cultural exchange between the island and neighbouring regions. In other words, artistic and architectural evidence as well as material culture (as will be seen in Chapter 6) indicate that Cyprus became a zone of cross-cultural interaction rather than a cultural barrier. Moreover, leaving their decorative program aside, the refurbishing or (re)building of churches across the whole island points to the considerable economic capacity of the ecclesiastical hierarchies at a local (rural) and episcopal (urban) level well into the ninth century.

Consider Polis-Arsinoe, whose bishopric seems to have vanished after the seventh century according to a traditional interpretation of literary sources. ${ }^{295}$ Indeed, as already hinted at, recent archaeological excavations have yielded evidence of a significant refurbishment of an early sixth-century three-aisled basilica north-east of a major intersection in the city marked by a tetrapylon built in the Roman era. ${ }^{296}$ The newly built church was vaulted like those documented in the Karpas peninsula and Paphos, documenting the presence of this architectural type in the north-western part of the island. A second basilica was discovered not far away. ${ }^{297}$ From the late seventh to the ninth century (and possibly beyond) both churches became the focal points of mixed-use environments of workshops, roads, and burial grounds. In fact, social and economic differentiation between the two communities has been deciphered in the peculiar layout of two local cemeteries. ${ }^{298}$ Indeed, the burials around the second basilica revealed luxury items (jewellery, rings, gold buckles, and bronze coins) as opposed to stone artefacts yielded in the burials around the first one. 
The importance of the local Church as a catalyst of a rather complex social and economic life comes to the fore here and interconnects with similar roles played by central authorities and local magnates. The economic capacity of the Church, its resources stemming from its place among the major landowners (although difficult to trace in the sources), its investments in remarkable (at least by eighth- and ninth-century standards across the Empire) building and artistic programs, and the centrality of urban and rural shrines in the pilgrim routes across the eastern Mediterranean sustained the level of local demand while at the same time bolstering the Church's centrality as a socio-political actor at a local, regional, and interregional level. Church's actions somewhat echoed the administrative and legal tasks that the local ecclesiastical hierarchy and the bishoprics handled not only within the provinces of the Empire but also in Umayyad-ruled Syria and Palestine, where they were responsible for maintaining the economic health of the local communities by minting and sanctioning the so-called pseudo-Byzantine or proxy coinage: an attempt to replicate widely known Byzantine originals to ensure acceptance in the marketplace. $^{299}$

On an island with multifaceted and multifunctional socio-political actors, the Cypriot Church thus did not preside over a separate reality with divergent political trajectories from the rest of the Empire and decreasing connection with the neighbouring regions. This not to deny the pre-eminence of charismatic leaders (like the Archbishop Constantine at the Seventh Ecumenical Council of Nicaea), but to overturn the impression of their role as last ditch champions of Orthodoxy for a pared-down Byzantine state surviving the Arab conquests. ${ }^{300}$ The economic, social, and political activism of the archbishopric and local ecclesiastical hierarchies should be viewed instead in the context of the Cypriot middle ground, where they acted as real promoters of cross-cultural exchange between the island and coterminous regions rather than hegemonic actors of local politics. One should describe them as privileged members of the new elite sketched above rather than solitary custodians of the splendid isolationism of an all-saints' island. Thus, their contribution to the construction of the Cypriot middle ground is visible in the church foundations reflecting the social coherence at village and city level, the material wealth of Cypriot elites/donors, the levels of local demand, and the persistence of exchange networks with the Muslim and Byzantine worlds.

What emerges is a picture less of an island dotted by deserted cities and ruralized communities than of a place of connectivity and economic interaction. Indeed, as Cypriots know very well, the winds that shake the island at every turn of season herald changes. Unpleasant as they may be, they blow strongly across the mountains and the plains, but seldom cause damage beyond repair. A reminder of the fact that "the insular dark centuries" in the Late Antique and Byzantine Mediterranean may have been less dark on Cyprus than elsewhere, because the consequences of Islamic maritime expansion were less ruinous to insular prosperity as economic, social, political, and cultural spaces of interaction and connectivity. ${ }^{301}$ 


\section{Notes}

1 Mas Latrie (1851-1862).

2 Ibid., 76-7. Curiously, and relying mainly on archaeological evidence, a similar approach can be found in Michaelides (2001), 194-9.

3 Archimandrite Kyprianos (1788).

4 Mas Latrie (1851-1862), I, 86.

5 Hackett (1901); Hill (1940-1952), I, pp. 257-39; Gunnis (1936). See on this, Davis and Stewart (2014), 17-28 and Chapter 2, n.5.

6 Parani (2014). Parani basically repeats verbatim the conclusions drawn by Michaelides, who earlier stated that the basilicas built from the fourth to the mid-seventh century on Cyprus stemmed from the political, military, and religious stability enjoyed by the island before the first Arab incursion (Michaelides (2001), 194).

7 Wickham (2005), 256. Also Cosentino (2013a), Haldon (2012b), 3-5 and Haldon (2016).

8 Laiou and Morrisson (2007), 38. On the plague see also Rosen (2007).

9 McCormick (2001), 783.

10 Metcalf (2009), 376. Metcalf, however, does not mention any source and I myself have not found any reference to the Egyptian fleet in the accounts of the coup by Sebeos (Thomson, Howard-Johnston, and Greenwood (1999), I, 58), Theophanes (Mango and Scott (1997), 298-9), Theophilus of Edessa (Hoyland (2011), 59-61) and John of Nikiu (John Bishop of Nikiu, 198-9). The latter source, as Whittow points out, seems to indicate (John Bishop of Nikiu, 198) that the rebels had stopped the supply of Egyptian grain (Whittow (1996), 78).

11 Wickham (2005), 713-14; McCormick (2001), 102; Teall (1959). Laiou and Morrisson (2007, 33-4) state:

In the sixth century the annona consisted on the one hand of military rations ... on the other of the annona civica: commodities ... destined for distribution in the capital and in few other cities... The shipping of these huge quantities required some 500 ships in three rotations between Egypt and Constantinople.

12 Wickham (2005), 713-14.

13 Dagron (1985), 437-8. See also Morrisson and Sodini (2002), 208 and Laiou and Morrisson (2007), 35; see also McCormick (2001), 104.

14 Wickham, pers. comm.

15 Venantius Fortunatus (1996, 2).

16 On Cyprus in the Roman period see Mitford (1980), with further bibliography. Also, Metcalf (2009), 346-51. On the sources concerning the Roman period see Orphanides and Wallace (1990) and Cobham (1908), pp. 1-5.

17 Mitford (1980), 1295-1297. See also Hadjisavvas (2010), 209. Also, Kyrris (1985), 161.

18 Mango (1984a), 4.

19 Lokin (2005).

20 Laterculus Veronensis (1876, 68-71). Barnes (1982), 201-8, states that the list of western provinces was written between 303 and 314, whereas that including the eastern one was added between 315 and 324. See also Bury (1923). The Notitia Dignitatum is an early fifth-century official list of Roman civil and military posts. It has been preserved in a sixteenth century copy of a missing original and it represents an essential source of information on the administrative organization of the late Roman Empire.

Notitia Dignitatum, 4.

See also Lokin (2005), 160-4; Chrysos (1993), 3-6 
21 Cassius Dio, Roman History, 54.4.1.

22 Lokin (1986). Also Mitford (1980), 1295-7.

23 Malalas, XII.48 (Jeffreys, Jeffreys, and Scott (1986), 170). Seismologists, however, have contested the assertion that ruinous ocean waves were actually caused by the earthquake (see Ambraseys (1962), 899).

24 Justinian, Novellae, VIII (13 May 535), p. 5; Metcalf (2009), 357; Lokin (2005), 191-7; Lokin (1986), 6. According to Metcalf (2009, 537), "part of the background of this change was Justinian's move, in 537, to impose Chalcedonian orthodoxy on Alexandria and Antioch, taking the political initiative away from recalcitrant Monophysites. Cyprus was well out of the struggle".

25 Justinian, Novellae, L, 1:"Scimus pridem sacram facientes constitutionem, secundum quam tuae gloriae tradidimus quinque has provincias, Cariam et Cyprum et in circuitu positas insulas, insuper et Mysiam ac Scythiam, ad constituendum eas sub tua gloria, adicientes et sub appellatione factas causas per memoratas provincias nequaquam ad gloriosissimos nostros praefectos, sed ad tuam remitti magnificentiam. Quia igitur multi adierunt nos ex Caria et Rodo et Cypro difficultatem patientes et dicentes cogi se frequenter hiemis tempore venire ad Scythiam et Mysiam, ubi degis, et ibi appellationes forte neque pro magnis pecuniis exerceri, et periclitari etiam maria transeuntes longa et venire ad provincias a barbaris inquietatas, propterea perspeximus hanc legem scribere ad tuam gloriam: ut ex Scythia quidem et Mysia causas tamquam ex vicinis existentes tua celsitudo secundum se audiat, aliarum vero, hoc est ex Caria et praedictis insulis et Cypro (si ab initio ipsae apud gloriosissimos nostros praefectos exercebantur, ex sacra iussione nostra traditae provinciae iudici), si quidem affueris huic regiae civitati, etiam eas apud te moveri et examinari una cum gloriosissimo quaestore sacri nostri palatii in sacro auditorio, sicut super appellationibus posita lex explanat." The Novella clearly stated that the five provinces of Mysia, Caria, Rhodes, Caria and Cyprus had been recently under the control of the Quaestor Bonus, to whom the edict was directed.

26 Maas (2005), 120; also, Lokin (1986), 6-7, and Haldon (1999), 68. The most recent summary of the status questionis concerning the quaestura exercitus can be found in Gkoutzioukostas (2009). Other important contributions are those of Florin Curta: Curta (2006), 46-8; Curta (2002).

27 Haldon (1999), 68. Also Haldon (1990), 210.

28 According to Lydus (Lydus, De Magistratibus republicae Romani, 2.29):

Justinian instituted a prefect as answer to the Scythian forces, having set aside for him three provinces which were almost the most prosperous of all: Kerastis (it is called now Cyprus) ... all of Caria and the Ionian islands.

(Quoted and translated by in Pohlsander (2006), 38).

29 Demesticha (2013), 177. For the production centres of LR1 amphorae see Jackson, Zelle, Vandeput and Köse (2012).

30 Guillou (1988), 11-13; Malamut (1988), 51-7. For a detailed description and the history of the geology of the island see Wright (1992), 5-11.

31 Petre (2012), 117-44.

32 Ibid., 10; also, Guillou (1988), 11-12.

33 Papacostas (1999).

34 Strabo, Geographica 14.6 (681-5), in Cobham (1908), 3.

35 Ammianus Marcellinus, Res Gestae 14.8, 14 (Rolfe (1971-1972), 1:73). Palladius wrote: "You served me the food of the fig-fattened and thirst-provoking pigs from Cyprus [and] quench my thirst with Cypriot wine" (Palatine Anthology 9.487); whereas Synesios stated: "The lightest wine, the thickest honey, the thinnest oil and the heaviest wheat [from] Cyprus" (Synesios of Cyrene, Ep. 148). Finally, 
Nonnos of Panoplis praised "the fruitful land of honeyed Cyprus, [where] flourished the two-colored generations of wild creatures with horns" (Dionysiaka 5.611-15). For translations of these authors, see Pohlsander (2006), 8 (Palladius), 20 (Synesios), 26 (Nonnos).

36 Curta (2002), 17; Haldon (1999), 74; see also Bakirtzis (1995), 247-53. See also Fejfer (1995). One could even mention here the large number of Late Antique shipwrecked cargoes with amphorae surveyed off Cape Andreas (the northeasternmost point of the island). They could indeed provide further evidence of the state-sponsored annona convoys: see Green (1973).

37 Bakirtzis (1995), 251; also Michaelides (2001), 208-10.

38 Kyrris (1984), 161; also Lokin (1986), 9.

39 Foss (2003); Kaegi (2003), 48ff; Whittow (1996), 69-95; Howard-Johnston (2006).

40 Gregory (2005), 156; also Zavagno (2011), 451-4.

41 Wickham (2005), 257-8.

42 Thophanes (Mango and Scott, 1997, 460ff); Sebeos (Thomson, Howard-Johnston, and Greenwood 1999, 58); see Kaegi (2003), 46; Metcalf (2009), 375-6.

43 Kaegi (2003), 46.

44 Zavagno (2011), 452 with further bibliography. Metcalf has pointed out that gold solidi were also struck in Cyprus, mentioning - but without any quotation - the analysis of two styles of die-cutting (supposedly) proposed by Hahn, who also attributed semisses and tremisses to Cyprus. Metcalf (2009), 376. Foss tends to dismiss the issuing of gold coinage (Foss 2008, 6)

45 Zavagno (2011), 453.

46 Whittow (1996), 72-4.

47 For the fall of Jerusalem and its impact upon contemporaries, see Kaegi (2003), 78-9 with further and detailed bibliography.

48 Life of Saint John the Almsgiver, suppl. 6 (1948, pp. 213-14)

49 Ibid., 2 (1948, p. 199)

50 Delehaye (1964), 5-64; Déroche (1995); Mango (1984a), pp. 25-41; Life of Saint Symeon the Fool (1974), 259-331

51 John Moschos' Spiritual Meadow (2002).

52 Efthymiades and Déroche (2012), 74-5; Rapp (2014), 34; Rapp (2015), 398-408; Mango (1984b), 40-1.

53 Mango (1984b), 73. Also Rapp (2015), 399.

54 Life of Saint John the Almsgiver, 6 (1948, 202). On his Amathontian origins, see ibid., 45 (pp. 256-7). Amathos, located a few miles north of Limassol, spread across a massive ridge of high ground and directly faced the sea on its southern slope.

55 Life of Saint John the Almsgiver, 4 (1948, 201).

56 Leader (2000), 407.

57 Metcalf (2009), 52. On the complicated and to some extent mysterious history of the discovery of the "two" treasures of Lapethos, see Merillees (2009), with further and up-to-date bibliography on the subject.

58 Merillees (2009), 54-7; Dodd (1961).

59 Leader (2000), 408:

"In eleven scenes, David is summoned from his flock of sheep to meet the prophet Samuel; he is anointed the new king of Israel by Samuel (since King Saul of Israel is no longer in God's favor); David argues with his brother Eliab after he comes into Saul's camp and hears about the reward for killing the giant Goliath, the champion of the enemy Philistines; David offers to fight Goliath, countering Saul's worry that he is just a boy by telling the king that he has killed the lions and bears that have threatened his sheep; Saul provides David with armor for his oncoming fight, but David decides not to wear it; 
David and Goliath confront each other and the young hero successfully slays the giant (presented in three scenes); and finally, David is married to Saul's daughter Michal, as part of his reward for killing Goliath."

See also Morales, Norris, Schwarz, and Watts (2001), 7.

60 See Whittow (1996), 69-81; Kaegi (2003), 58-228; Foss (2008), 9-12; also Sarris (2011), 253-8.

61 Nikephoros (1990, 54-5).

62 Although Chrysos (1993), 13) and Foss (2003), 165-6) rely upon some passages of the Life of Saint John the Almsgiver to conclusively show that the Persians raided Salamis-Constantia and they later withdrew after having taken some prisoners, Metcalf (2009), 383-5 has asserted that such statements are not corroborated by any material evidence.

63 Life of Saint John the Almsgiver, 13 (1948, p. 206)

64 Dedeyan (1995), 122.

65 See, for instance, Theophylact Simocatta (1986, I. 15.15, 132). Also John of Ephesus (in the first half of the sixth century) recalls the episode, as he reports that the captives were "in pagos omnes totius insulae divisi" ( (1860, VI, 15).

66 Procopiou (2014).

67 Ibid., 86.

68 Zavagno (2011), 455-6 with further bibliography.

69 Ibid., 457.

70 Life of Saint John the Almsgiver, suppl. 45 (1948, p. 256). On the church dedicated to Saint John and the forgotten memory of his cult in Amathos, see Papacostas (2014), 197-8.

71 Ibid., 4. On the financial wealth of the Patriarchate see Kaegi (2003), 80-1.

72 Life of Saint John the Almsgiver, suppl. 18 (1948, p. 228).

73 Abdellatif, Benhima, König, and Ruchaud (2012), 10.

74 Dunn (1998). On the fortifications at Kyrenia see Megaw (1985a), 210-14; Papacostas (2012), 82; Petre (2012), pp. 231-55.

75 Sodini (1988); Mitford (1950). See also Kaegi (2003), 208-9. Also Metcalf (2009), 385-7; Papacostas (2012), 81; Stewart (2016), 6-8.

76 Kennedy (2007a), 70. There is clearly no space here deal with a detailed narration of the complex origins of Islam and the events leading to the invasion of Syria and Palestine, which is dealt with by authors like Kennedy (2007a), 34-65, Kaegi (1992), 66-146, Donner (1981) and Donner (2012) and Sarris (2011).

77 Zavagno (2011), 460 with further bibliography.

78 Schulze, Schulze, and Leimenstoll (2006). See also Chapter 3 n. 151.

79 Browning (2005); also Mansouri (2001) and Mansouri (2014), with a detailed summary of the Muslim narratives and chronicles.

80 Kaegi (2003), 285.

81 John, Bishop of Nikiu (1916, CXX, 72).

82 Borrut (2001), 21; also Mansouri (2014), 99-100.

83 Conrad (1992), 344-5. Also Borrut (2001). On the defensive network set up by the Umayyads on the Syrian-Palestinian coast see Taxel (2013a).

84 Jeffreys and Pryor (2006), 19-34; Wellhausen (2004); Kennedy (2007a), 324 43; also Mansouri (2014), 100; Browning (2005), 242-7.

85 al-Balādhurī (1916, XIII, 235); al-Ṭabarī (1985-2000), IV, 258).

86 al-Ṭabarī (1985-2000), 4:258.

87 The fullest account of the Arab invasion of Aradus-Arwād, although partially unreliable due to the abundance of topoi and narrative motives (Conrad 1992, 349-64) can be found in the Kitāb al-futūh of Ibn A'tham al-Kūfī written in mid-ninth century (Ibn A’tham al-Kūfĩ (1968-1975, XII, 352ff.).

88 Beihammer (2004), 50. 
89 al-Tabarī (1985-2000), IV, 258). Also, Howard-Johnston (2010), 364-7; also Beihammer (2004), 50-1 and Mansouri (2001), 29, the latter with a full list of the Arab sources incorporated by al-Tabarī.

90 al-Balādhurī (1916, XIII, 235).

91 Kalipha ibn Hayyat, Kitāb al-Tarih, 92 quoted and translated in Mansouri (2001), 227.

92 Kennedy (2007a), p. 368.

93 Chronicle of ibn al-Athîr, III, 75 as quoted and translated in Cobham (1897), 84.

94 De Thematibus, 40.14.

95 Wellhausen (2004), 35-45.

96 al-Balādhurī (1916, XIII, 235); Agapius of Manbij (1912, 480); Dionysius of Tel-Mahre, Chronicle, in Palmer (1993), 93; Theophanes, 344 (Mango and Scott (1997), 478). See also Christides (2006)13; Jeffreys and Pryor (2006), 24-5; Papacostas (1999), 208-11 and Metcalf (2009), 395-418.

97 Life of St. Therapon, 684-5 quoted in Cobham (1908), 232.

98 Dionysius of Tel-Mahre (Palmer (1993), 96-108). On the methodological problems concerning this source see Chapter I and Howard-Johnston (2010), 194.

99 Theophanes, 344 (Mango and Scott, 1997, 478)

100 Beihammer (2004).

101 al-Kūfî (1968-1975, XII, 349).

102 Beihammer (2004), 55.

103 Christides (2006), 12; The excerpt of Qudama b. Ja'far, Kitāb al-Karaj wa-Sina'at al Kitabah, is quoted in Mansouri (2001), 32-3.

104 Papageorghiou (1964), 152-8; Kyrris (1997).

105 Beihammer (2004), 49-52.

106 Des Gagniers and Tinh (1985), 116-25; Noret (1986), 445-7.

107 Dionysius of Tel-Mahre (Palmer 1993, 97).

108 Zavagno (2011-2012), 132. Christides (2006), 25.

109 Stewart (2008), 73-5; Dikigoropoulos (1961), 180-3. Karageorghis and Maier (1984), 292-301; Stewart (2008), 73-7; Zavagno (2011), 467-8; Caraher and Papalexandrou (2012); Caraher, Moore, Olson, and Papalexandrou (2013); also Metcalf (2009), 418-22.

110 Zavagno (2011), 470-3.

111 Christides (2006), 22.

112 Balandier (2003), 261-72.

113 Efthymiades and Déroche (2012), 77; Theodore of Paphos (1953, 44-5). According to Efthymiades and Peter van den Ven, this hagiographic panegyric heavily impinged upon a previous life of the saint written in iambic verses by Tryphillos in the fifth century and therefore must be regarded as a case of metaphrasis ante litteram.

114 Sozomen I. 11 (Sozomen 2015, 27)

115 Theodore of Paphos (1953, 87). Papacostas (1999), 92; Metcalf (2009), 387-90.

116 Laiou and Morrisson (2007), 81.

117 Theodore of Paphos (1953), 81.

118 On this naval confrontation (known in the Arabic sources as Dhāt aș-Sawārī) off the costs of Lydia see Cosentino (2008), 586-90, and Kennedy (2007a), 327-9 with detailed bibliography and analysis of the relevant sources.

119 Metcalf (2009), 101; see also, Metcalf (2004), 83-100 and n.455 of the catalogue.

120 The translation is in Neal (2010), 15; on the inscriptions see also Metcalf (2009), 221-4; Papageorghiou (1993), 43; Megaw (1986), 512; Des Gagniers and Tinh (1985), 116-25.

121 Neal (2010), 15.

122 Theophanes (Mango and Scott, 1997, 478-9); Dionysius of Tel-Mahre (Palmer 1993, 108). 
123 al-Kūfī (1968-1975, XII, 352ff.)

124 al-Balādhurī (1916, XIII, 236).

125 Beihammer (2004), 68.

126 Anastasios of Sinai, $96(2006,114)$. On this source, see Haldon (1992).

127 Zavagno (2011-2012), 135.

128 Levy-Rubin (2011).

129 Haldon (2010c), 2.

130 Jenkins (1953); Dikigoropoulos(1958); Papageorghiou (1964), 154; Browning (1977-1979); Megaw (1986), 505-19; Kyrris (1985), 635-46; Beihammer (2004); Lilie (2005); also Lounghis (2010), 13-21 and Malamut (1988), $105 \mathrm{ff}$.

131 Christides (2006); Mansouri (2001); Cameron (1992); Beihammer (2002), 6-7.

132 Theophanes (Mango and Scott (1997), 484).

133 Jeffreys and Pryor (2006), 26-7; see also Kennedy (2007a), 324-43.

134 Jeffreys and Pryor mention the 670 invasion without providing any source for their statement (Jeffreys and Pryor (2006), 26); it is possible that they relied on Dikigoropoulos $(1958,98)$, who tried to argue that an Arab garrison, if installed after 653 , must have been withdrawn soon afterwards and reinstated in 670-1 when Cyprus was denied to the Byzantines in view of the Arab siege of Constantinople (as supported by the numismatic evidence, i.e., the supposed lack of coins of Constantine IV for the period 668-80 whereas they circulated post-680 when the garrison left Paphos). For the Arab rule over Cyprus, see Lilie (2005), 68-9 and Zavagno (2011-2012), 132-3.

135 Theophanes (Mango and Scott (1997), 494).

136 Theophanes (Mango and Scott (1997), 506); Agapius (1912), 497); Christides (2006), 34 n. 97; Howard-Johnston (2010), 226-7; Metcalf (2009), 297; 416; 583; Jeffreys and Pryor, 190-2; Foss (2008), 38; Taxel (2013a), 77 with further bibliography.

137 Zavagno (2011), 464-6.

138 al-Balādhurī $(1916,236)$.

139 Theophanes (Mango and Scott, 1997, 496). See also Jeffreys and Pryor (2006), 27.

140 Zavagno (2011), 472-3 with further bibliography.

141 Also Metcalf (2014), 64 and Metcalf (2013a); Prigent (2012), 82.

142 Kennedy (2004), 81-102.

143 Theophanes (Mango and Scott (1997), 506; with a slight variant the same terms are repeated by Constantine Porphyrogennetos in DAI, p. 94; see Zavagno (2011-2012), 131-5; Lilie (1976), 101-4; Christides (2006), 44-5; Metcalf (2009), 416-18; Ditten (1993), 142-4; Dionysius of Tel-Mahre (Palmer 1993, 128); and Michael the Syrian, Chronicon (Chabot 1899-1910, II, 470). The treaty is also referred to by the Arab sources (al-Balādhurī, 13.237, and al-Ṭabarī, 7:258, although these dated it to the aftermath of the first raids as signed by Mu'āwiyah. On the treaty see Kyrris (1985)177-8, and Dikigoropoulos (1958), with further bibliography. On the political conditions of the late seventh century, see Christides (2006), 44-5; Kennedy (2004), 90-103 and Kennedy (2007a) 327-30;

144 Nicholas Mystikos, ep. 102 (1973, 525-6).

145 Christides (2006), 44; on the hybrid regime, see Kyrris (1985), 177-8.

146 al-Balādhurī (1916, XIII, 238-42); Ibn Sallām (1988, 223-8); see Mansouri (2001), 17-21; also Christides (2006), 34.

147 Signes Codoñer (2005), 46-7; also Cau Ontiveros and Mas Florit (2013).

148 Quoted by Ibn Sallām (1988, 227); see also Kyrris (1997), 626. See also Beihammer (2002), 44-50.

149 Theophanes (Mango and Scott, 1997, 509); DAI,47 quoted in Pohlsander (2006), 115; Michael the Syrian (Chabot 1905, II, 470); al-Balādhurī (1916, 238). On the transformation of the monetary system on the part of 'Abd al-Mā lik see Foss (2008), 59-60 and Ilisch (2010); also Walmsley (2007), 59-64. 
150 al-Balādhurī (1916, XIII, 238).

151 DAI 47 quoted in Pohlsander (2006), 115. On the foundation of Nea Justinianoupolis, see primarily Englezakis (2010); Stewart (2008), 78-81; Metcalf (2009), 450-5; Kyrris (1985), 165-6.

152 Metcalf (2009), 31. For the sigillographic evidence, see Metcalf (2004); also Brandes (2002), passim. For the magnates' titles, see Metcalf (2004),242 and Metcalf (2009), 81-92.

153 Caraher and Papalexandrou (2012), 274.

154 DAI 47 quoted in Pohlsander (2006), 115.

155 Hinderaker (2004), 360

156 Ibid., 370.

157 Metcalf (2009), 445.

158 Browning (1977-1979), 65.

159 Beihammer (2002), 47.

160 White (1991), 76.

161 Lounghis (2010), 11.

162 Beihammer (2002) presents the reader with a detailed description and exhaustive bibliography concerning the seventh expeditions staged by the Arabs against Cyprus in the period under consideration in this book. Two of them (in 746 and 790) simply used the island as a base or stopover in the confrontation between the Byzantine and Muslim navy, the other five represented only temporary breaches of the status quo soon to be restored. See Ibn al-Athī (2008, IV, 141) and al-Tabarī (1985-2000, VII, 227).

163 Theophanes (Mango and Scott (1997), 662); also al-Ṭabarī, Ta'rīkh, VIII, p. 320. On the reorganization planned by Harun al-Rashid see Haldon and Kennedy (1980), 107-15; Whittow (1996), 215-19.

164 De Thematibus, 40. See above Chapter 3.

165 Theophanes (Mango and Scott, 1997, 662).

166 al-Ṭabarī (1985-2000, VII, p. 320); see also Lounghis (2010), 13; and Treadgold (1988), 144-5.

167 Life of St. Demetrianos (1907, 232-3).

168 White (1991), 53.

169 Theophanes (Mango and Scott, 1997, 683).

170 Ibid., 616. See Lounghis (2010), 79, and Metcalf (2009), 445.

171 Stewart (2008), 46-7, 97-106; contra Farace (2015).

172 See on this Griffith (2008), and Levy-Rubin (2011).

173 Megaw (1950a); Metcalf (2009), 286-7; Metcalf (2013a), 73; Christides (2006), 113-21; Stewart (2008), 72; Nicholas Mystikos, Ep. 102 (1973, 525-6).

174 Vionis (2013a), 104-8.

175 Ibid., 116-17.

176 Stewart (2008), 360.

177 Vita Petri Atroae 101(1956, 169). For Willibald, see Introduction, n. 2 and infra.

178 Eutychius of Alexandria, 111.11130. See also Papacostas (1999), 52.

179 The passage is quoted in Cobham (1908), 5.

180 On the thematic organization and its origins, see Haldon (1990), 208-32; also Wickham (2005), 127-8 with further and detailed bibliography; on the concept of "dhimmitude", see mainly Griffith (2008), 16-20 with further bibliography.

181 On these events, Theophanes (Mango and Scott, 1997, 542-9); on the karabisianoi fleet see Ahrweiler (1961), 81-5, and the more recent and up-to-date contributions of Jeffreys and Pryor (2006), 31-2, and Lounghis (2010), 11-12.

182 Lounghis (2010), 24; Jeffreys and Pryor (2006), 106.

183 Jeffreys and Pryor (2006), 113.

184 Theophanes (Mango and Scott (1997), 586); Anastasius Bibliothecarius (1841, 171). See also Lounghis (2010), 11. As I have already mentioned elsewhere, 
Anastasius's passage has been wrongly attributed to Paul the Deacon by Dikigoropoulos, Kyrris, and Roberts (Dikigoropoulos (1961), 39-40; Kyrris (1985), 285-7; Roberts (2000), 55-6). As a matter of fact, Paul the Deacon never mentions an attack on Cyprus in his Historia Langobardorum. See on this Zavagno (2011-2012), 130 n. 66.

185 Dennis (2010), 57; on the Taktika, a military handbook written in the late ninth to early tenth century and later revised by Constantine Porphyrogennetos, see also Haldon (2014). Also Herrin (2009), 144-5; Whittow (1996), 172. According to Lounghis the choice of Antalya was owed to the fact that the harbour was located just opposite Cyprus and had been known for its first-quality shipbuilding since the fourth century (Lounghis (2010), 27).

186 Metcalf (2004), nos. 153, 270-2. One of these seals has been recorded as found in Salamis-Constantia during the excavations at the Basilica of Saint Epiphanios (see Metcalf (2009), 418). For a detailed summary of the sigillographic evidence mentioned here, see Metcalf (2009), 31, 463; also Metcalf (2004), 101-6; Brandes (2002), passim; Lilie (2005), 83-5.

187 Lilie (2005), 83; Metcalf (2009), 462.

188 Lilie (2005), 83; Metcalf (2004) 206 no. 111. Treadgold (1988), 248-9. On Crete, Baldini (2012), 245; on Malta, Bruno (2009), 84-6; on the Balearics and Sardinia, see Signes Codoñer (2005), 58-9.

189 For the magnates' titles, see Metcalf (2009), 81-92. Metcalf (2004), 112-25; 242; nos. 152, 154, 270-2 (the latter dated to the end of the eighth century, however).

190 Sicily: Theophanes Continuatus, II, 81-2; Balearics: Scholtz and Rogers (1970), 77-8.

191 McCormick (2001), 506ff.

192 Oikonomides (1972), 351.

193 Morrisson (2002), 915; also Laiou and Morrisson (2007), 86-7; Prigent (2013), 158.

194 Nef and Prigent (2006), 35-41.

195 Metcalf (2004), no. 269 (provenance unknown). For the seal of the kommerkiarios of Sicily, see Metcalf (2004), no. 221; also Metcalf (2009), 119.

196 Zavagno (2009), 71-2.

197 Tzougarakis (1988), 169-73 with further bibliography.

198 Baldini (2012), 245

199 Ibid.

200 Zanini (2013a), 186.

201 For a reassessment of locally made Cretan ceramics, see Armstrong (2009), 163-4 with further bibliography. On the level of coin circulation, Cosentino (2013a), 71 with further bibliography. A graphic showing the similar number of copper coins minted from the early seventh to the early eighth century found on the three "major" islands can be found in Zavagno (2011-2012), 128.

202 Bruno (2009), 15.

203 Bruno and Cutajar (2013).

204 Brown (1975), 87; Bruno (2009), 84.

205 Bruno and Cutajar (2013), 28.

206 Brown (1975), 87; Bruno (2009), 84.

207 The passage is translated in Amengual i Batle (1991), 445. For a good summary of the historiography of the Balearics from the seventh to the tenth century, see Signes Codoñer (2005) and Signes Codoñer (2007).

208 On these different hypotheses, see Cau Ontiveros and Mas Florit (2013) 41 with further bibliography; see also Signes Codoñer (2005), 47.

209 Kaegi (2010), 257-60.

210 Signes Codoñer (2005), 98-101.

211 Cau Ontiveros and Mas Florit (2013), 40-1; also Signes Codoñer (2005). 
212 de Nicolás and Moll (2013).

213 Signes Codoñer (2005), 47-9; Vallejo Girvés (2012), 474-5.

214 Zanini (2007), 30-4.

215 Signes Codoñer (2005), 59.

216 Brubaker and Haldon (2011), 485.

217 Oikonomou (2005); also Delehaye (1907); Rapp (2014), 30-1;

218 Acts 13:4-6. On Barnabas's life on Cyprus, see Acts 15:39; also Oikonomou (2005), 99-105; and Megaw (2006), 395.

219 Rapp (1993); Rapp (2014), 397-8; Papacostas (2014); also Englezakis (1995b).

220 Papacostas (1999), 147ff; Papageorghiou (1985a); Megaw (1974); Stewart (2008), 58-60; Rautman (2003).

221 Megaw (1974); Ćurčić (1999); Ćurčić (2000); Stylianou and Stylianou (1985); Papacostas (1999), 209; Stewart (2008), 34-6 with further bibliography

222 Papacostas (1999), 209.

223 Stewart (2008), 38-41.

224 Dikigoropoulos (1965-1966), 253-63.

225 Theophanes (Mango and Scott (1997), 614).

226 Halkin (1945).

227 See n. 76 above.

228 Dikigoropoulos (1961), 132-5; Metcalf (2004), 363-72.

229 Metcalf (2004), 370-2; see also Dikigoropoulos (1965-1966).

230 Metcalf (2009), 472. Caraher, Moore, Olson and Papalexandrou (2013).

231 Caraher and Papalexandrou (2012), 285.

232 Dunn (2007). See also Zavagno (2011-2012), 139 with further bibliography.

233 Metcalf (2004), 85 and n. 455; Caraher and Papalexandrou (2012), 285.

234 Metcalf (2004), 489-90; for Aradus-arwād, see also Conrad (1992).

235 Mansi, 13:78-80.

236 See Chapter 3 n. 70.

237 This half of the section partially relies on the overview of the history of the Cypriot Church I included in my article "At the Edge of the Empire": see Zavagno (2011-2012), 136-44. See also Englezakis (1995a).

$238 B H G, 35$ with further bibliography; trans. Pohlsander (2006), 24. See also Efthymiades and Déroche (2012), 76.

239 Itinerarium Antonini Placentini 1.2.88 (1977, 35). This travelogue (itinerarium) is traditionally ascribed to Antoninus Placentinus because its first sentence invokes a local martyr named Antoninus, and the journey has been variously dated to ca. 570 or ca. 550; see Brock, Caner and Price (2010), 252-74, with further bibliography.

240 On Willibald, see Talbot (1954); McCormick (2001), 129-34; and Wilkinson (1977), 222; also Chapter 1, n. 2.

241 Anastasius of Sinai $(2006,10-11)$.

242 Wilkinson (1977), 207 (dating the $\log$ to the early 8th century); Brubaker and Haldon (2011), 322 (dating the log to the early 9th century).

243 Vita Petri Atroae 101 (1956, 169). On this saint, see Brubaker and Haldon (2011), 395; and Papacostas (1999), 101.

244 Life of Saint Auxibius, 3-6 (1993, p. 56).

245 Life of Constantine the Jew, in AASS, Nov. IV, 635.

246 Johnson (2006), 140. In particular, one of the miracles involved a boat of Cypriot pilgrims coming to the saint's festival in Seleucia that was saved from being crushed on the rocks of Isaurian coast during a thunderstorm; see also Papacostas (2001), 184.

247 Mansi, 4:1125, gives the list of signatures of Cypriot bishops attending the Ephesian Council: Sophronios of Paphos, Zeno of Kourion, Rheginos of Constantia, and Evagrios of Soloi. Also Bowersock (2000),10; Dikigoropoulos 
(1961), 86; and Mitziadis (2005), 129-54. In particular, on the strained relations between Antioch and Cyprus, see Downey (1958).

248 Laudatio Barnabae Apostoli 2.4.40-1 (1993, 111-21); as already mentioned, the Laudatio was written in the beginning of the sixth century by Alexander, a monk of the monastery of Saint Barnabas near Salamis-Constantia. Here we must mention that this source was highly hostile to Peter: see Downey (1958), 227.

On the discovery of the body of the saint and the copy of the Gospel of St. Matthew found on his chest (later presented by the bishop Anthemios of Salamis-Constantia to the Emperor Zeno (425-91 A.D see Theodore Lector or Anagnostes, II 571.2, 183-4. See on this episode Megaw (2006) also Delvoye (1980).

249 Stewart (2008), 66.

250 Pohlsander (2006), 24; Megaw (2006), 396-9. The building of this church is also mentioned by the fifth-century Life of Saint Epiphanios $8.40 .4(1859,46)$.

251 Delvoye (1980); Papageorghiou (1985b); Papageorghiou (2011), 175-80; Papageorghiou (2011), 376-7; Roux (1998); Megaw (2006), 400-1.

252 See Chapter 3, n.181.

253 Theophanes (Mango and Scott, 1997, 122); see also Zavagno (2011-2012), 13640 with further bibliography.

254 Life of Saint Epiphanios 8.40.4 (1859, 46).

255 Polybios of Rinocouda, Vie de Saint Epiphanius, quoted in Chavaud and Yon (1978), 23-4, and in Stewart (2008), 222.

256 Hugeburc, Vita Willibaldi 1-2 (1954), 161.

257 Karageorghis and Maier (1984), 295.

258 On Paphos, see Karageorghis and Maier (1984); Megaw (1988); Metcalf (2009), 281-5, 457-61. On the two churches, see Stewart (2008), 49-51; and Stewart (2010), 162-9.

259 Theodore of Paphos (1953, 110-11). See also Chrysos (1993), 7; Papageorghiou (2011), 415-24.

260 Delehaye (1907), 229-30; Mansi, VI, 568, 567.

261 Pouilloux (1987), 80.

262 Stewart (2008), 285. Metcalf $(2009,374)$ labels some Persian prisoners who were resettled on Cyprus from eastern Syria and Armenia in second half of the sixth century as Monophysites; however, I found no reference to them as Monophysites. Both Chrysos and Papacostas (although not quoting any primary source) use the term Christian Armenians (Chrysos (1993), 8-9, and Papacostas (2001), 108). The same applies for Hill (1940, III, 281), who, however, quotes Theophylact Simocatta as the main source for the episode. Simocatta, indeed, only mentions that the prisoners were of Persian origin.

263 Sodini (1973); Sodini (1988), 619-34; also Mitford (1950). See also Stewart (2016).

264 Déroche (1995), 20. On the Severians (also known as Encratites), see Eusebius, IV, 29.2-7 (Schaff and Wace 2007, 208-9).

265 On the doctrine of Monothelism (the belief that Christ had only one will), see Mango (2002b), 106; and Herrin (2009), 94-5. Monothelism led to persecutions of Orthodox opponents like Maximus the Confessor and Pope Martin I and was banned at the Sixth Ecumenical Council in $680 \mathrm{CE}$.

266 Mansi, X, 913-16; Déroche (1995), 21-31.

267 Modern Artaki few kilometers to the north-west of Cyzicus: see Englezakis (2010), 69-71.

268 Theophanes (Mango and Scott, 1997, 509).

269 Metcalf (2009), 450-5; Englezakis (2010), 72-4; Stewart (2008), 78-81.

270 Englezakis (2010), 74. On the possible motives, see Kyrris (1997), 631-2; Stewart (2008), 79. 
271 Mansi, XI, 961. The translation of the passage is in Stewart (2008), 78. On the Quinsext Council, see Gregory (2005), 162, 176 with further bibliography.

272 Englezakis (2010), 81. DAI, 47-8; see Kyrris (1997), 672-4.

273 Englezakis (1995a), 49.

274 Dikigoropoulos (1965-1966), 266.

275 Metcalf (2009), 466.

276 Mansi, XIII, 77. A lead seal possibly belonging to the archbishop is recorded by Metcalf (2004), n. 458

277 I am referring here to Brubaker and Haldon (2007); and the recent Brubaker (2012).

278 Sakellion (1912-1913), 225-85 and 349-66.

279 The sermons are summarized and translated by Metcalf (2009), 444-5. See also Dikigoropoulos (1961), 199.

280 The passage of the Life of Saint Stephen the Younger is in Auzépy (1997), 79; also PG 100:1117-1120.

281 Theophanes (Mango and Scott, 1997, 641).

282 Brubaker and Haldon (2011), 234 47.

283 Ibid., 275.

284 Englezakis (1995a), 49.

285 Megaw and Hawkins (1977), 33-5, 147-9; Metcalf (2009), 225; Papacostas (1999), plan at 6a, description at 70. Also Dikigoropoulos (1961), 190; Stewart (2008), 49; Papageorghiou (2011), 241-57; Browning (2005) 258-60.

286 Eutychios of Alexandria, 2: 55-6.

287 Stewart (2008), 41-9; Stewart (2010).

288 Papacostas (1999), 145; Stewart (2008), 39; Metcalf (2009), 421. The church is associated with the first bishop of Thamassos, Herakleidos, who was a disciple of the apostle Barnabas. See Halkin (1973); Koztakoğlou (2005), 537-40, 674-82.

289 On the southwest basilica of Amathos, see Stewart (2008), 40; see also Karageorghis (1967), 363; on the basilicas of Salamis-Constantia, see Dikigoropoulos (1961), 180-3; Papacostas (1999), 71, 85, 90, 110, 144, 177; Papageorghiou (1986), 495; Papageorghiou (1985b), 311-13; Stewart (2008), 66-7, 72ff.; Delvoye (1980); on Saint Herakleidos see Dikigoropoulos (1961), 226-67; Papacostas (1999), 80-1, 144; Stewart (2008), 34.

290 Michaelides (1993), 77-8; Michaelides (2001), 212-13. See also Metcalf (2009), 264-5.

291 Stewart (2008), 38; Papageorghiou (2011), 283-8; Koztakoğlou (2005), 537-43; Dikigoropoulos (1961), 185 and Remsen (2010), 72-3. The unpublished survey I referred to was directed by A.H.S Megaw in 1958 and since the church is located in the occupied north of the island, no further excavations have been conducted since then.

292 Stewart (2008), 38; Dikigoropoulos (1961), 186; Papacostas (1999), 84, 149, 182, 200.

293 Stewart (2008), 99.

294 Vionis (2013a), 116.

295 Dikigoropoulos (1961), 231.

296 Caraher, Moore, Olson, and Papalexandrou (2013), 83-7.

297 Caraher and Papalexandrou (2012), 274.

298 Ibid., 275.

299 Wickham (2005), 232-42; Haldon (1990), 131-52; Haldon (2016), 249-85; Walmsley (2010), 26-8; Zavagno (2011), 468-75 with further bibliography

300 Wickham (2005), 265.

301 Cosentino (2013a), 73. 


\section{Urban versus rural The many sides of the Cypriot coin}

\section{Overcoming the caesurae}

This chapter presents an overview of Cypriot rural settlements and urban centres and the changes they faced in the transitional period. As in the next chapter, the foundation of my research is largely archaeological and relies upon the various surveys and excavations conducted primarily in the Republic of Cyprus. Therefore, the subject matter of the current chapter is traversed by two caesurae. The first is geographical, as the numerous research projects focusing on urban centres or the rural landscape in the last forty years have provided good evidence but are limited to the southwestern half of the island. ${ }^{1}$ For the rest of the island one can only rely on poorly documented and partially published rural surveys, which, although extremely useful to tip the interpretative balance (as will be seen), are nevertheless out-of-date in terms of methodology and analytical approaches as they predate the tragic events of 1974. As mentioned in Chapter 1, the same holds true for pre-1974 urban archaeology in the northeastern half of Cyprus. Not only have some urban centres (Kyrenia, Lapethos, and partially Soloi) been almost completely glossed over by excavators but so have the publications concerning the Late Antique and early medieval phases of better (in terms of coverage and methodological awareness) excavated cities like Salamis-Constantia. Acknowledgment of this lapse is almost non-existent. ${ }^{2}$ Given this state of affairs, it is not surprising that a comprehensive survey of Cypriot urbanism in the early Middle Ages has never been attempted. Scholars both before (Dikigoropoulos, Karageorghis, and Megaw) and after 1974 (Papageorghiou), as well more recently (Papacostas and Metcalf), have preferred to focus their attention on the events of single urban centres. ${ }^{3}$

They seem somehow under the spell of such Late Antique authors as Stephen of Byzantium, Hierokles, and George of Cyprus, who between the early sixth and early seventh century listed the fourteen or fifteen (the actual existence of Lefkosia-Nicosia is problematic) cities that dotted the island. ${ }^{4}$ In fact, by preferencing the analysis of the fate of single cities rather than a systematic overview of the functional and structural transformation of Cypriot urbanism, these scholars gave pride of place to the problem of continuing Roman legacy 


\section{Urban versus rural}

(in terms of architectural practices, social habits, and cultural traditions) in Byzantine urban centres. In their minds, it is clear that even in Late Antiquity the newly Christianized cities of Cyprus were - in appearance as much as in their public style - very much late Roman centres. ${ }^{5}$ This leads us to the second caesura, which is chronological and framed within the traditional historiographical debate on Byzantine urbanism. This debate began in the 1950s with Ostrogorsky and Kazhdan and continued in the works of Claude, Foss, Liebeschuetz, Brandes, Lavan, Saradi, and Haldon, to mention but a few. ${ }^{6}$ More often than not the argument has been framed within the opposition between "continuists" and "discontinuists". The former stressed that cities did survive physically; that, while they may have shrunk and were often confined to their citadels as a result of constant enemy harassment, they nevertheless retained their roles as centres of commercial activity, petty commodity production, and administration. The latter argued for a total collapse of the antique urban organization, and of social and economic life. As I have already mentioned, on Cyprus the discontinuist approach has been privileged, with the Arabs being held responsible (with few exceptions) for the destruction, shrinking, or abandonment of most of the flourishing Late Antique Cypriot cities, including the capital Salamis-Constantia.

Sketching such a picture has its advantages, especially as it seems to fit hand in glove with the results of field surveys in rural areas across the southern part of the island within the last two decades. ${ }^{7}$ Rautman and McClellan clearly delineate the frame of the traditional historiographical approach:

The archaeological record shows that Cyprus in the first half of the seventh century was a thriving commercial and agricultural province with a densely settled hinterland. In the latter part of the century the situation abruptly changed: some coastal sites (Amathos, Kourion, and Soli (sic.)) were almost completely abandoned and others (Paphos, Constantia, and Kyrenia) appear significantly reduced. By the eighth century new inland centres had developed at Agios Tychonas, Episkopi, and perhaps at Yeroskipou. Field surveys ... have proved that few traces of human activity could be found in the Cypriot countryside between the eighth and the tenth century. ${ }^{8}$

Indeed, it is important to add analytical and methodological nuance to this picture. On the one hand, there are well-documented subregional differences, as not all the rural sites surveyed across the island developed along similar chronological trajectories and, above all, did not encounter the same abrupt decline in the first decades of the seventh century due to the mass movement of people to the foothills and innermost parts of the island. ${ }^{9}$ Indeed, if, for instance, it is clear that in areas like Kalavasos-Kopetra small settlements had a short and busy life from the mid-sixth to the mid-seventh century followed by reduction and abandonment, other areas, like parts of the socalled Akamas peninsula (Agios Kononas) or the eastern part of the Kyrenia 
range, were probably frequented well into the eighth century, although on a diminished scale. ${ }^{10}$

On the other hand, a further problem emerges when considering the main indicators of the supposed decline: pottery, coins, and ecclesiastical buildings. These are often analysed in purely quantitative terms as contrasting with the data yielded in the late Roman period, especially referring to the disappearance of African and Phocaean fine wares, the rarefied amount of bronze and gold coins, and the lack of impressive ecclesiastical buildings on par with the fourth- and fifth-century basilicas. As the latter issue has been addressed in the previous chapters, we should only note here that we indeed face a gap in our knowledge of seventh- and eighth-century Cypriot material culture of rural and urban settlements. This gap is mainly owed to the changing shapes and decoration of Cypriot fine wares and amphorae as well as to the increased production and distribution levels of locally made pottery paired with an analytical approach that more often than not glosses over the transformation of land use settlement patterns. ${ }^{11}$ Athanassopoulos has indeed pointed out that archaeological surveys have often showed a much more complex picture of localized episodes of desertion and resettlement: changes in density and settlement patterns mirror economic expansion and contraction, different agricultural strategies, and demographic oscillations. ${ }^{12}$

Adopting a more wholistic approach is urgent, considering the chronic lack of well-published surveys and the need for an all-encompassing scansion of historical change in rural and urban societies in the passage from Late Antiquity to the early Middle Ages. ${ }^{13}$ This should be paired with a careful revision of the chronology of the ceramics, which should lead us to challenge the traditional idea of an entrenchment of rural villages in the mountainous interior paired with the collapse of the coastal sites. ${ }^{14}$ Here, one must acknowledge that a call for an interpretative framework should first consider the differences in the coverage of the surveyed areas. These differences partially hinge on the current political divide: the two most extensively examined parts of the Cypriot countryside are the south-central (including Amathos and the Vasilikos and Maroni valleys) and the southwestern coastland (encompassing the environs of Paphos). Indeed, as will be seen the northern and eastern coastal strips (from Cape Kormakiti to Apostolos Andreas and from the latter to Cape Greco) have escaped the focus of modern extensive and intensive surveying. Moreover, as Gregory stresses, survey strategies have shown a preference for low lying areas: "Thus when we find that Byzantine and medieval pottery tends to concentrate in coastal plains [or valleys] we should remember that these areas have been surveyed more intensively". 15

To this problem one may also add the aforementioned inability to recognize eighth- and ninth-century pottery and the possible existence of settlement patterns other than those determined by safety and defence needs. Indeed, successful results have recently come from a (re-)examination of specific types and ranges of pottery, ${ }^{16}$ and - again as Gregory had hoped - we have also grown more aware that these hide many differences because they encompass a 


\section{6}

\section{Urban versus rural}

period of centuries, during which there must have been significant changes in settlement and use patterns. Such an approach has the merit of opening new lines of research, which have seldom come to fruition. For example, in the case of the Akamas survey and the Canadian Palaepaphos Survey Project (CPSP) both Rupp and Fejfer and Hayes have urged us to consider that if it is true that the use of land changed and permanent settlement was abandoned in favour of a less intensive and more seasonal system of cultivation, this owed less to a sudden event (such as the Arab raids), which at most might have provided a further stimulus for reorganizing pre-existing settlement patterns. ${ }^{17}$

This reorganization did not present itself simply as a political, administrative, and economic entrenchment but rather as the result of a deliberate policy geared toward the maintenance of the infrastructure of existing cities, towns, and villages with a more diverse profile. This reflects the data (such as the previously mentioned ecclesiastical buildings, surveys, and numismatic evidence) traditionally used to confirm the irreversible breakdown of the social and, above all, economic city-countryside circuits of interaction. Rather, as already hinted at, the continuity in the occupation of many rural sites and the establishment of new farming and industrial settlements in the eighth century found expression in the construction of churches (like those erected across the Karpas peninsula and beyond) or in the presence of artisanal ateliers (like the glass workshops documented by slags and wasters dated to the seventh century and later in Soloi, Agios Philon, Kourion, and above all Paphos-Saranda Kolones). ${ }^{18}$

The very fact that similar building activities or commercial and artisanal facilities have been documented in urban sites like Salamis-Constantia, Paphos, and Polis-Arsinoe should also encourage us to contextualize the social repercussions of changes on rural and urban settlements and even the possible movement of sizeable segments of the population. Here a mere quantitative approach celebrating the prosperity of rural and urban communities from the fifth to the seventh century, when five-century basilicas mushroomed across the island and large numbers of coins were deposited, should be reappraised by recognizing that social and economic changes on Cyprus were consistent with the downturn of the Mediterranean exchange system. ${ }^{19}$ In other words, as will be seen in Chapter 6, if the Cypriot economy and its material indicators showed a downturn, this had less to do with any particular event on the island (like the Arab raids) than with the ripple effects of the fragmentation of the Mediterranean. This fragmentation also influenced the systemic reorganization of the political, military, and administrative structures of the Byzantine Empire vis-à-vis the presence of the more and more sophisticated state machinery of the Caliphate in Damascus. ${ }^{20}$

We must also admit that even the most recent contributions on the problems of rural and urban settlement patterns sometimes deliberately choose to limit their scope to the seventh century as it is easier to find comparative material evidence for this period and to systematically pair the excavated 
structures (often basilicas) with those found in neighbouring areas both within and beyond the island. ${ }^{21}$ However, as Maria Parani has recently yet cautiously admitted:

The continuous existence in the aftermath of the Arab incursions (at least in places like Polis-Arsinoe) of small-scale installations for manufacture and retail products catering to the needs of the local market and surrounding countryside point to the integration of artisanal activities in the fabric of the Cypriot city in a continuation of earlier urban practices. ${ }^{22}$

With this in mind, what I propose in the following pages is a historical overview of the main developments of urban and rural sites that would avoid a search for a breakdown and its causes by trying to intercept the persistence of citycountryside economic and social interaction in the seventh to ninth century as underpinned by the resilience of elites who remained urban-oriented and subelites who - at village or town level - remained viable enough to contribute to extensive rebuilding programs and economic activities. By treating the scarce literary sources and the available material evidence as a single group one should be able to catch a glimpse of the urban and rural life on the island as less in tune with dramatic caesurae than with the gradual and slow transformation of local settlement patterns. This is important for two reasons.

First, it will show that at least some rural communities remained politically and economically coherent. ${ }^{23}$ Indeed, it is possible here to adopt for Cyprus the model that has been proposed by Chris Wickham and Peter Brown: the fragmentation of large holdings of land (secular as well as ecclesiastical) in the passage from Late Antiquity to the early Middle Ages allowed more space for peasant social and economic action and did not bring about the disappearance of local rural communities. ${ }^{24}$ Here a comparison with contemporary Syria and Palestine is possible, although in Cyprus we simply cannot witness the same degree of aristocratic patronage and state-sponsored intensive land use strategies as in the seventh- and eighth-century Levant. ${ }^{25}$ Moreover, we cannot retrieve any complex urban hierarchy (on a functional, urbanistic, or architectural basis) of the kind Walmsley and others have documented for early Islamic Syria and Palestine. ${ }^{26}$ Nevertheless, as will be seen, on Cyprus one can hypothesize the existence of resilient seventh- to ninthcentury rural communities at least in some areas of the island, because their socioeconomic standing is reflected in the production and distribution of local ceramics or other artisanal/commercial activities and in the construction of peculiar ecclesiastical buildings. Indeed, rural communities moved away from the patterns of landowning and patronage that gave birth to the huge basilicas of the fifth and sixth centuries and reconfigured themselves around less prominent but still coherent lines possibly based upon local village leaders (often including local clergy) and reflecting the narrow horizons of interregional exchange. However, landlord-tenant and, above all, patron-client relations retained their importance, as aristocrats partially living in Cypriot cities 


\section{8}

Urban versus rural

continued to support circuits of city-countryside exchange and urban centres funnelled imported goods into the Cypriot interior uplands.

Second, if levels of habitation and economic activity in rural settlements remained substantial, this also fed into the presence of local urban markets for agrarian and non-agrarian production - in other words, the city-countryside production, demand, and distribution circuits we have repeatedly referred to. The economic function of local ecclesiastical authorities, small- to medium-scale property owners (magnates and possibly monasteries), and the Byzantine fiscal administrative and military machinery allow us to question what Koder has labelled as the (supposedly) uniform early seventh-century decline of settlements, because from 650 to 750 the revival of urban and quasi-urban settlements was a result of the resilience of trade. ${ }^{27}$ Indeed, a good degree of microregional differentiation emerges from rural surveys for some areas of the island that had more adequate resources and, above all, could benefit from the vicinity of substantial urban outlets mainly - but not necessarily - located along the coasts.

This is clearly visible in some of the areas surveyed in the last decade, like the area around Politiko-Mitseri villages on the Mesaoria Plain (the focus of the Sydney Cyprus Survey Project). This area clearly benefited from the proximity of two urban centres - Soloi, a window on the surviving extent of long- and medium-distance Mediterranean networks of exchange, and Tamassos, an ideal market for local villages or farmsteads - at least until the second half of the seventh century. ${ }^{28}$ Another example of urban sites acting as outlets for local agricultural productions is offered by the Vasilikos area on the western half of the Kyrenia range, where the famous seventh- to eighth-century Dhiorios pottery kilns were found in the 1970s. ${ }^{29}$ Although the survey is clearly outdated (although well-published), it may be possible to surmise that the production of domestic and cooking wares, which has been documented in other urban and rural sites across the island, was partially supported by the existence of two important cities like Lapethos and Kyrenia. The former, in particular, is mentioned by the Chronicle of Pseudo-Dionysius of Tel-Mahre as a harbour town frequented by the Byzantine administrative and military elites, evidenced by the aforementioned discovery of the Lambousa-Lapethos treasures (including the David Plates.) $)^{30}$

This is not to say that Cypriot cities and the countryside did not begin to experience an economic or a demographic decline in the second half of the seventh century or that even in Late Antiquity these areas suffered more than others from the economic simplification of the Mediterranean system of exchange. It is only to be expected, for instance, that the fall of the Egyptian tax spine would have serious repercussions on the social, demographic, and economic life of areas like the Akamas region or the Paphos chora, where the annona fleet had temporary and functional stops. But, as will be seen, these areas were helped by the resilience of a macro-class of urban elites that supported the reorganization of different rural areas and the readjustment of land-settlement and land-ownership patterns as centred 
on politically and socially coherent villages that retained their economic functionality. $^{31}$

Finally, and more importantly, what will emerge from the following overview will hopefully allow us to refute the idea that the Arab raids brought about a final devastation and to overturn the long-standing perception of a process of urban decay and abandonment in seventh- to ninth-century Cyprus. These goals will be achieved by advocating for a similar strategy to that implemented in Syria and Palestine, where an overwhelming preoccupation with site and settlement histories stemmed from narrowly defined research objectives, which were further curtailed by the existing convention. ${ }^{32}$ This strategy is based upon an analysis of the detailed conditions of single urban centres or rural areas but from a wider perspective that pays heed to the different social, cultural, and economic roles the elites and sub-elites played in the aftermath of the Arab invasions and during the fragmentation of the Mediterranean networks.

\section{Surveying the Cypriot countryside}

The following two sections of this chapter present a two-pronged effort to address the same issues, for we will try to simultaneously consider and align the cultural, political, and economic life of the urban and rural populations on Cyprus rather than compartmentalizing them. Furthermore, while analysing urban developments and the changes in settlement process in the countryside based on excavations or landscape surveys we should also keep in mind that the evidence preserved in the material cultural record (archaeology and architecture) will be used to visually present an overview of those areas which preserved clear traces of social and economic vitality and therefore betrayed the presence (in terms of patronage or simply residence) of the local elites. It goes without saying that this "map" inevitably shows a certain degree of carelessness. It will be based on a selected range of the better published and well-documented excavations as well as heavily indebted to catalogues of rural and urban sites written by Papacostas, Rautman, Dikigoropoulos, and Metcalf, among others, and it will reflect the dearth of documentation in the northern part of the island. Finally, the "map" we create will have to ignore the material unearthed during the most recent campaigns conducted during the composition of this book. ${ }^{33}$ Nevertheless, the reader will be presented not only with a view of the current state of archaeological research at urban sites and in rural contexts but also with a set of interpretative tools that will be used later to address the complexities of Cypriot early medieval economy.

In two contributions, Maria Pazari and Tønnes Bekker-Nielsen effectively reconstructed and simulated on a modern road atlas the road system that encompassed the whole island of Cyprus in the Roman period, as shown in the Peutinger Table. ${ }^{34}$ As already stressed by Mitford, who paired the Table's evidence with the milestones (miliari) recovered across the island, one can trace three main axes connecting the main urban sites dotting the island: "the first from Paphos to Salamina through Soloi, Lampoussa, Keryneia, and 
Hytroi; the second, following the south coastline, from Paphos to Salamina through Palaia-Paphos, Kourion, Amathos, and Kition; and the third road, starting from Soloi crosses the island, passing through Tamassos and Tremetoussia". ${ }^{35}$ In truth one could easily regard the first and the second as the north and south branches of a ring-road that followed the coastline, a sort of overland complement to the more common journey around the island described by Orosius in the fifth century and later discussed by Arab geographers like Ibn Khurdādhbeh (late ninth to early tenth century), al-Muqaddasī (second half of the tenth century), or Abu' al-Fīdā (early fourteenth century). They stress that one would have needed twelve days to circumnavigate the whole 250mile-long island. ${ }^{36}$ Therefore, it is my intention to pursue this archaeological journey across the early medieval Cypriot landscape by following the path of the Roman roads (which in all probability remained in use during the Byzantine period), passing through more or less frequented rural areas while connecting the main urban centres.

Our starting point will be the narrow northern strip of fertile land extending from Cape Kormakiti in the west to Apostolos Andreas in the east, following the Kyrenia-Pentadaktylos mountain range. The entire strip was the focus of an important survey by scholars such as Catling and Megaw. ${ }^{37}$ As briefly mentioned in the previous chapter, the northern coastline was dotted with important cities boasting important harbour facilities. Moving from west to east a traveller would have encountered Lapethos, Kyrenia, and Carpasia (modern Agios Philon). The latter, although not included in the Peutingerian Table, is mentioned by Hierocles Grammatikos in his sixth-century Synekdemos that listed the thirteen poleis found on Cyprus. ${ }^{38}$ Corresponding almost exactly with the aforementioned coastal towns, on three peaks of the Pentadaktylos lay three fortified strongholds (today known as the "Crusaders' castles" of Saint Hilarion, Buffavento, and Kantara) meant to both watch the maritime traffic moving along the north coastline and guard the mountain passes giving access to the Mesaoria Plain.

As we will return to the castles and to the above-mentioned cities in the following sections of this chapter, I would rather stress here that the strip and the hilly landscape looming behind it were the focus of the aforementioned landscape surveys, which yielded a wide array of numismatic and ceramic evidence. In particular it is worth mentioning the well-published investigation conducted by Catling and Dikigoropoulos at Kornos Cave (on the hills overlooking Lapethos) and the small rescue excavations in the nearby area of Dhiorios-Mersineri, both in the mid-1950s. ${ }^{39}$ According to Catling, the latter were of a piece with a number of sites within the administrative district of Lapethos, which he describes as substantial villages or large farms remaining vital into the seventh and eighth centuries. ${ }^{40}$ In fact, the Dhiorios-Mersineri area revealed a small pottery factory that remained active until the mid-eighth century. In the same period the nearby small settlement of Kormakiti, partially centred around the little church of Panagia Kriniotissa, also remained frequented. Here a silver miliaresion jointly issued by the emperors Artavasdos 
and his son Nikephoros and dated 742/43 was found in the destruction layers of an early Byzantine building, pointing to the settlement's continuous occupation until at least the mid-eighth century. ${ }^{41}$

The peculiar style of the fourteen kilns in the pottery workshops discovered at Dhiorios-Mersineri and the stratigraphic analysis of the sherds allowed Catling to identify a typology of ceramic as Dhiorios domestic wares. This type has been found across the island and dated to the late seventh and first half of the eighth century. ${ }^{42}$ It points to the existence of a well-developed distribution network of local products (possibly including late Cypriot Roman wares) that stretched to the eastern Mediterranean and beyond. ${ }^{43}$ In particular, domestic wares and cooking pots of the types produced at Dhiorios (both wheel- and handmade) have been documented at Kornos Cave (possibly a hermitage depending on a Syrian monastery), Salamis-Constantia (in the so-called "public bench deposit" and in the refurbished church of Saint Epiphanios), Amathos, Kourion (destruction layers of the basilica), and in the Maroni-Petrera area. ${ }^{44}$ It seems possible that the northwesternmost part of the Kyrenia range retained a good degree of social and economic coherence that clearly lasted until the mid-eighth century, when the area was abandoned for reasons that remain unknown. ${ }^{45}$ Indeed, Catling blamed the abandonment on an outbreak of the bubonic plague in 747 , although there is no evidence for this. ${ }^{46}$

Signs of continuous occupation and economic vitality of rural areas in the passage from Late Antiquity to the early Middle Ages are also documented at the other extreme of the Kyrenia range. Here, in an area between SalamisConstantia and the Karpas peninsula, Papacostas has argued convincingly that numerous sites continued to be frequented well into the medieval period, although others - for instance the early Byzantine settlement of Koutsopetrika may have been abandoned in the mid-seventh century. ${ }^{47}$ Two early Christian basilicas (Agia Trias and Panagia tou Kyra near Libadia) may have been frequented during the eighth century. ${ }^{48}$ In particular, the church of Panagia tou Kyra, sitting at the edge of a fertile piece of land, could preserve traces of a rebuilding phase dated to the ninth century or even earlier, which would make it contemporary with the barrel-vaulted churches of the Karpas peninsula. $^{49}$

It is to these churches that we will now turn, as they help us to partially countermand the traditional view of the archaeology of the Cypriot countryside, which exalts the busy life of the local rural communities from the fifth to the mid-seventh century. ${ }^{50}$ As Stewart has pointed out in his remarkable studies, the Panagia Chrysiotissa and the Asomatos Church in the town of Ourania-Aphendrika (on the northern coast of the peninsula, some ten kilometres away from Carpasia), the church of Panagia Koroveia at Sikhada, the basilica of Agia Varvara at Koroveia, and, finally, the church of Panagia Kanakaria at Lythrangomi should all be regarded as examples of a new type of barrel-vaulted ecclesiastical building and dated to the early eighth century. ${ }^{51}$ 


\title{
122 Urban versus rural
}

The skills required of the artisans who erected and decorated these churches are such that they must reflect the economic resilience of local rural communities, while at the same time pointing to the level of demand underpinned by the ecclesiastical and secular elites still (partially) based in the surviving urban sites dotting the island. In a famous 1995 statement, McClellan and Rautman assert:

\begin{abstract}
The archaeological record shows that Cyprus in the first half of the seventh century was a thriving commercial and agricultural province with a densely settled hinterland. In the latter part of the century the situation abruptly changed. By the eighth century new inland centres had developed at Agios Tychonas, Episkopi, and perhaps at Yeroskipou. Field surveys (Palaepaphos Project, Vasilikos Valley, etc.) have proved that few traces of human activity could be found in the Cypriot countryside between the eighth and the tenth century. ${ }^{52}$
\end{abstract}

More than twenty years later we can vigorously reassess this apparently definitive interpretation by illustrating that collectively the archaeology of the Karpas peninsula reveals how the economic resilience of parts of the Cypriot countryside flowed into a building program that - though incomparable with the fifth- and sixth-century basilicas - was substantial enough to dismiss the idea of the complete abandonment of once thriving, densely populated, and prosperous rural communities. In other words, we are currently in a position to dismiss the identification of any single event (military or natural) as the common cause triggering a catastrophic settlement change. This not to assert that the whole Karpas peninsula was occupied with uniform intensity; indeed, excavations at the area of Phlamoudhi on the western coast of the peninsula (although mainly focused on the Bronze Age) have shown that in the early Byzantine period the area experienced a contraction of its economic and social life. $^{53}$

However, one can safely conclude that in Cyprus we face a complex and slow change of settlement patterns as recently demonstrated by Rautman for the low valleys of the Troodos range. ${ }^{54}$ This reminds us once again of eighthcentury Syria, where changes in land use were not simply the result of a socioeconomic failure but a deliberate and planned shift to a new agricultural regime. We simply do not possess for Cyprus the same awareness of either the natural or human factors that drove the transformation of Syria in the early Islamic period (e.g., land impoverishment and new irrigation projects, different ways of exploiting natural resources, and new industrial projects). Moreover, we do not have the same level of knowledge of the material culture of the period, particularly concerning potter, the guide fossil par excellence, as we have for the Levant in the transitional period. Nevertheless, we can assume that at least until the mid-eighth century and possibly even later continuity of occupation and economic vitality emerges from the results of intensive and extensive survey in rural contexts. In these contexts, the mushrooming of 
barrel-vaulted churches, for instance, seems of the highest importance. As Stewart stresses: "these basilicas mark a clear shift away from early Christian architecture: vaulting replaced wood roofs, square-pier arcades supplanted previous colonnades, local stone replaced imported materials, mosaics gave way to frescos, and narthexes were eventually omitted". ${ }^{55}$ It is, therefore, clear that local communities invested substantial resources in rural ecclesiastical buildings as well as in cities like Salamis-Constantia, Polis-Arsinoe, and Paphos. The informal elites should have retained a partial hold on local landowning, although diminished in terms of wealth and popularity, which allowed them to sponsor restoration and refurbishment programmes of buildings like baths, churches, and fortifications, while at the same time underpinning local artisanal and commercial activity as shown by the workshops and shops dotting the urban landscape. ${ }^{56}$

Leaving the Karpas peninsula, the vision of an economically vital seventhand eighth-century Cypriot countryside becomes less clear. Evidence from different surveys and excavations conducted along the southern and western parts of the island appears to conclusively indicate decline. The KalavasosKopetra survey, the excavations in the Kouris Valley, and the extensive survey of the Akamas region (the westernmost corner of the island) unquestionably reveal fewer sites, particularly in the immediate hinterlands of coastal cities like Amathos and Paphos. ${ }^{57}$ At Kalavasos-Kopetra, in fact, excavations have shed light on a small settlement (including a monastery, a church, and two residential buildings), which, according to numismatic and ceramic evidence, reached peak prosperity in the late sixth to early seventh century, with subsequent increasing isolation and instability causing its definitive abandonment. ${ }^{58}$ Events seem to have taken a dramatic turn especially in the area of the monastery, with the Arabs as the usual suspects: "A summary burial of nine individuals in the cistern has been linked with the social upheaval caused by the Arab raids. This dramatic break in occupation was followed but signs of architectural collapse and reduced levels of activity [with the entire structure coming] to an end in the mid seventh century as the ruins provided shelter for the remaining inhabitants and their animals". 59 Similarly, an ecclesiastical building, again possibly a monastery, unearthed in the village of Alassa in the Kouris Valley, was shown to have had a very short life, as it was devastated by a fire and abandoned in the second half of the seventh century (evidenced by the coins in the charcoal and ash layers), although the excavators did not provide any evidence linking the event with the Arab incursions. ${ }^{60}$ Moreover, in the eighth to twelfth century the area of Potamia-Agios Sozomenos seems to have been devoid of human activities, though the previous two centuries appear to have been an age of bustling activity revealed by the large quantity of African and Cypriot fine wares dated to the Late Antique period discovered during an extensive survey of the area ${ }^{61}$

Finally, on the Akamas peninsula, at the northwesternmost extremity of the island, a rural, marginal rather than central, area has been surveyed. It encompasses a local centre (Agios Kononas) and its hinterland documented 


\section{Urban versus rural}

as an ancient landscape gradually abandoned around 700 and virtually untouched since then. ${ }^{62}$ The excavators correctly identify - in my opinion one of the causes of the demographic and economic collapse as the end of the annona sea-traffic linking Constantinople with Egypt. In fact, archaeological underwater and land surveys at the anchorage of Kioni have revealed how large grain ships, although not able to dock in the small coves dotting the coastline of the Akamas peninsula, could have used them as watering stops or as shelter from storms. ${ }^{63}$ A similar fate fell to the harbour site Agios Georgios to the south of Kioni in the area of Cape Drepanon, the most westerly point of Cyprus. ${ }^{64}$ The site, which boasted two basilicas and a bathhouse, thrived in the first half of the sixth century and remained in use until the beginning of the seventh century as a stopping point for the annona grain ships, but it declined after the fall of Alexandria to the Persians. ${ }^{65}$

On the Akamas peninsula as well as Cape Drepanon, abandonment clearly predated the Arab incursions and therefore should be partially linked to the break of the eastern Mediterranean tax spine. In the case of KalavasosKopetra and the Kouris Valley, the imbalance between the quantity and quality is harder to explain. As repeatedly stated, we should be careful and concede that the desolation that supposedly gripped these areas has a lot to do with the problem of dating medieval pottery and the lack of proper stratigraphic context for dating stray finds, which does not allow us to quantify the amount of pottery from the transitional period. Moreover, the character of building techniques and land use is ignored in most of the rural and landscape surveys, as attention is drawn instead to the lack of lustre, downsizing, and the poor restoration of ecclesiastical buildings. This inevitably leads scholars to overlook or downplay the "successors" of the early Christian basilicas simply because they are reorganized as more compact architectural spaces and not lavishly decorated with marbles or mosaics but rather embellished with local limestone furnishings or built with spolia.

A vivid example of this approach is documented in the Akamas peninsula survey, where in Agios Kononas an early Christian basilica lying at the eastern edge of the site was restored sometime in the eighth century. ${ }^{66}$ As a detailed plan of this church has not been revealed, one cannot help but wonder if this could be another example of a barrel-vaulted church like those found on the Karpas peninsula and elsewhere across the island. It is also interesting that in the same period (or a little later) a quarry was opened in the area to provide lime and mortar not only for the restoration of the church of Agios Kononas but also for the building of two other churches (Agios Georgios and Agia Eirene) dated to the eighth to tenth century. ${ }^{67}$

A comparison with the coterminous region of Rough Cilicia, surveyed by Günder Varinlioğlu, can be helpful here. ${ }^{68}$ In Rough Cilicia, located just across the sea from the northern coast of Cyprus, the picture of regional distress determined by the establishment of the Arab-Byzantine frontier as presented in the written sources and recent historiography seems not be fully supported by the evidence on the ground. ${ }^{69}$ Indeed, the region was an intensively settled 
countryside in the fifth and sixth century, but the development of new political, military, and economic conditions impinged upon the pattern of settlement and land use by differently allocating and exploiting local resources. These changes were partially driven by the resilience of state and ecclesiastical elites and partially by the continuity of commercial activities in a less densely occupied landscape. $^{70}$

In a similar vein, the excavations in the hinterland (chora) of Sagalassos have allowed scholars to set forth a new interpretative framework by proposing the continuity of diverse kinds of rural settlements. ${ }^{71}$ The old model of a "decapitated" landscape resulting from the demotion of classical cities to simple villages and kastra seems to derive from the monumental ruins of Hellenistic Roman towns and the obtrusive nature of the remaining structures. ${ }^{72}$ Indeed, a more attentive analysis of pottery assemblages and ecclesiastical buildings has concluded that although the occupation of the rural hinterland of Sagalassos was less intensive than that centred upon elevated spots, there was no occupational gap after the seventh century. It was the nature of the occupation to change as the countryside returned to what it had been most of the time: a landscape composed of peer villages with areas of intensive cultivation paired with higher elevation sites associated with a more pastoral way of life. ${ }^{73}$ By the same token, Akyürek and Armstrong relied on ceramics and building activity to show that the Lycian countryside was not just an empty shell and that in truth changes in settlement patterns, economic exploitative strategies, and rural societies did not imply any abandonment or entrenchment in fortified inland hubs. ${ }^{74}$ In their opinion it was rather "the exaggerated importance given to the defeat of the Byzantine navy in AD $655 \ldots$ taken together with the universally accepted cut-off date of AD 700 for some of the most recognizable ceramics [that] created a hiatus in historical events which did not actually exist". ${ }^{75}$

We can draw a similar conclusion for Cyprus, where subsistence-oriented rural economic activities did not necessarily lead to the abandonment of lowland and coastal settlements. ${ }^{76}$ Here one should take into consideration the contribution of a revised chronology of ceramics (as will be further examined in Chapter 6), the aforementioned continuity of building activities, and sigillographic evidence. In particular, with regard to latter, one should think of the unusual site of Khlorakas, a village a few kilometres north of Paphos, where a large number of lead seals has been recovered and dated from the sixth to the first half of the eighth century. ${ }^{77}$ Specimens dated to the sixth century have been linked to the shipping activity from Alexandria putting in at Coral Bay or Agios Georgios. ${ }^{78}$ It is nevertheless remarkable that sealing activity in Khlorakas continued well after the collapse of the Egyptian tax spine focused more on local secular and administrative elites rather than on the ecclesiastical authorities. Seals of bishops and archbishops are indeed few, although an unusual specimen belonging to Theodore, metropolitan of Tyre (undated but provisionally assigned to the second half of the seventh century), has been unearthed in Khlorakas. ${ }^{79}$ This should be paired with two analogous 


\section{6}

\section{Urban versus rural}

specimens found in Amathos and at an unknown location on the island (together with another belonging to a deacon of the metropolitan) as they could point to the continuity of the shipping routes between the Levantine coast and the island after the Arab invasion of Syria and Palestine rather than to a relocation of the metropolitan and his church because of the Arab invasion of the Levant (an event not supported by any written or material evidence). ${ }^{80}$

This interpretation is further supported by another lead seal found on the island belonging to the Pantherios, Bishop of Arados, a little island off the Syrian coast some 200 kilometres from the eastern coast of Cyprus. ${ }^{81}$ The island belonged to the diocese of Tyre and was peacefully vacated by the local population after successfully withstanding a siege by Mu'āwiya on his way back from the first raid against Cyprus. ${ }^{82}$ Once again the supposed relocation of the local flock to Cyprus, as implied by Metcalf, finds no confirmation in the sources, for the Aradians, upon a second expedition mounted by Mu'āwiya, chose to resettle in the Syrian hinterland. ${ }^{83}$ The ecclesiastical Levantine seals found on the island, therefore, could hint at the active role played by Cyprus in the correspondence between Christian churches of Syria and possibly beyond and the local (and therefore Constantinopolitan) religious authorities. Once again the supposed caesura brought about by the Arab-Byzantine attrition does not correspond to the reality on the ground.

It is quite unusual to be able to trace the post-conquest official dialogue between eastern Mediterranean Christian communities in urban centres and rural areas such as Khlorakas. This case is all the more compelling because among the finds retrieved from Khlorakas are early eighth-century specimens, one of which belonged to Theodore patrikios. ${ }^{84}$ It is possible that he was a member of the informal elites ruling the island who retained vested landowning interest in the area, although his official title betrays his involvement in some administrative or governmental duties performed in a urban centre (Paphos?) not too far away from Khlorakas. Indeed, one cannot help but wonder if an extensive survey of the area would yield traces of architecturally modest and highly functional buildings (e.g., industrial installations, baths, or elaborate farm houses) of the type Yizhar Hirschfeld and Hugh Kennedy have documented in Palestine, pointing to the existence of landowning provincial elites. ${ }^{85}$

Notwithstanding the urgent need for further archaeological investigation, the sigillographic evidence from Khlorakas coupled with the barrel-vaulted basilicas of the Karpas peninsula and the ceramic kilns in Dhiorios should help us to propose rather different trajectories for the transitional Cypriot countryside, which will take into due consideration the quite fragmented geomorphological Cypriot landscape and the economic role of the local cities in orienting patterns of rural production, consumption, and distribution. Rather than indulging in a simplistic and all-encompassing model predicated upon a shift to the mainland and abandonment of coastal areas, when analysing rural settlements in Cyprus one must acknowledge the existence of diverse contemporary and coterminous trends partially hidden by our rather undeveloped knowledge of the period's material culture. 
A further comparison with Sicily could be helpful here. In fact, the heart of darkness of Sicilian archaeology covering the period from the seventh to the ninth century has been partially enlightened by some analysis focused both on the data of rural settlements and the production, consumption, and circulation of ceramic assemblage. As I will return to the second aspect in the following chapter, I will stress here that archaeologists dealing with the transitional period were confronted with similar methodological issues as those mentioned for Cyprus: difficulty in identifying and classifying "guide fossils", the low quality of stratigraphic research, and a lack of publication and obsessive interest in the better documented monumental phases of each site. ${ }^{86}$ Alessandra Molinari has argued convincingly that "[if] the number of deserted rural settlements increased considerably and entire districts appear to have been uninhabited, both surveys and archaeological excavations have revealed evidence of land settlement ... This pattern differs from the model devised by previous scholars of peasants settled on hilltops". 87 Sigillographic and numismatic evidence have also contributed to the refinement of the previous model of diffused "castralization" of the Sicilian landscape, as McCormick has also identified the island as a key point in the ancient trunk route between the Tyrrhenian Sea, Constantinople, and the Aegean Sea. ${ }^{88}$

The stability and vitality of Sicilian rural settlement should be pitted against the geomorphological peculiarities of the island, for one should not forget that the specialization of Sicily in grain production was essential for the survival of Constantinople after the loss of Egypt. Moreover, it is also important to recognize that eastern Sicily was more of a piece with the surviving transMediterranean exchange system, as the western half of the island experienced more fragmentation and regionalization of the Tyrrhenian network. In Cyprus we cannot identify a similar polarization, but we can nevertheless sketch a picture of a landscape in which abandoned sites (Kalavasos-Kopetra, the Kouris Valley, Potamia-Agios Sozomenos, and Maroni-Petrera) or settlements with diminished activity (Akamas, Politiko-Mitsero, and the Paleopaphos hinterland) coupled with other areas (the Karpas peninsula, Dhiorios-Kornos Cave, Khlorakas, and the eastern half of the Kyrenia range) in which social and economic life clearly continued. This continuity though was predicated upon different settlement patterns, size of demographic groups inhabiting the countryside, organization of production (agricultural and artisanal) and involvement of elites in estate management. Indeed, a hagiographic source like the Life of Saint Demetrianos, written by an anonymous author in the early tenth century, describes the Cypriot rural landscape as dotted with villages, towns, churches, and monasteries. ${ }^{89}$ With regard to the latter, as previously mentioned, the settlement hierarchy was still partially bound to ecclesiastical elites as our hagiographer mentions that the bishopric of Kythrea had dependent farmers to whom it had to provide cultivation implements. ${ }^{90}$

The Life of Saint Demetrianos is of course a later source, and as such should be handled with the kind of methodological and analytical care I stressed in Chapter 2. Nevertheless, one should interpret it as a window onto 


\section{8}

\section{Urban versus rural}

the vitality of Cypriot rural life as paired with the almost contemporary Life of Saint Constantine the Jew. As Lars Ryden has pointed out, the latter never describes the kind of organized rural (and urban) society we find in the former, for it includes no place-names or detailed descriptions of people and their duties. ${ }^{91}$ The impression, however, is that of a peaceful countryside jointly tilled by the Arabs and the Romans and dotted with churches, eremitic grottos (reminding us of the one surveyed at Kornos Cave), and even rock-cut chapels like those documented in Kyrenia-Chrysocava, where the frescoes seem to date to the tenth century, and in the area around the Panagia Pergaminiotissa in Akanthou, where they recall the eighth- to ninth-century Cappadocian churches. ${ }^{92}$ In short, a relatively harmonious coexistence seems to have existed between the Christians and the Arabs: a relatively successful political experiment that came to an end when the island was back under full control. ${ }^{93}$

Indeed, one should not confuse the informality of the Cypriot landscape with a point-blank economic retrenchment and sociodemographic desertion. First, the Arab raids did not wreak any havoc or have an irredeemable impact on the life of the rural community. The decline of the basilica- and villa-filled landscape had more to do with the breaking of the Mediterranean exchange system, especially along the southern coast. Even there, however, it is important to avoid proposing a one-size-fits-all model of the development of rural landscape and peasant society. As the Canadian Paleopaphos Survey Project has showed, "the location (according to pottery distribution) of Byzantine and medieval sites follows that of sites of all periods, although they are spread in a broad band along the coastal plain and then unevenly up the three river valleys (Ezousa, Xeropotamos, Dhiarizos)". ${ }^{94}$ Clearly the resilience of Paphos as an urban centre played a role in orienting the productive and distributive mechanisms of local rural society. Indeed, seventh- to ninth-century Paphos shows a degree of social and political frequentation and reveals a coherent and economically active urban cityscape organized around artisanal quarters. ${ }^{95}$

Second, the role of rivers in the distribution of local rural production and privileged means of communication have seldom been taken into account. ${ }^{96}$ Cyprus has many rivers, such as the Pedhios or Yalias crossing the Mesaoria Plain from east to west or the Kouris, Ezousa, and Maroni streaming from the Troodos range to the southern coast or, eventually, the Orygos flowing into the sea east of Soloi. Indeed, these were predominantly seasonal and intermittent streams whose flow rendered navigation problematic. Nevertheless, their valleys provided a favourable landscape for farming or even seasonal animal husbandry. A good example has been provided by the survey of the so-called Idalia section of the Yalias River located on the Mesaoria Plain between Nicosia and Salamis-Constantia. The Yalias Valley was actively inhabited in the Late Antique period and was slowly deserted throughout the transitional period, disproving the theory that only coastal sites were vacated as result of the Arab raids. ${ }^{97}$ More important, however, the Idalia section of the river, for which the survey report has never been fully published, ${ }^{98}$ yielded "numerous later sites, extending to the Dark Ages of the Arab raids, [which] 
bear witness to an active agriculture [although] they do not share the prosperity of their contemporaries of the northern coast". 99

Other areas may indeed present us with a different picture. The AthienouMalloura survey project, in the central part of the Mesaoria Plain in an area at the confluence of two streams northeast of the Yalias, showed a remarkable lack of stratified deposits for the period from the eighth to the twelfth century. However, the excavators have urged us to handle this conclusion with care, because the period of abandonment seems to be defined more according to political standards rather than any remarkable transformation of the material culture. So the sharp decrease in recovered early medieval sherds could be due to the poor knowledge of the pottery types dated to the period under scrutiny and our inability to date the end of the habitation of settlement based upon building and monumental activity. ${ }^{100}$ What clearly emerges from all of these studies is the need for a subregionally focused lens when examining the Cypriot rural landscape, as different geographical and morphological characterizations preclude a fully encompassing synthesis. A comparative approach should be adopted here, as it is clear that coastal sites were not uniformly abandoned and inland sites continuously occupied. In other words, the Cypriot landscape was more fragmented than previously thought, and economically and demographically vital areas depended for their success on a variety of factors, including the role of rivers.

Another factor is the resilience of at least some urban coastal centres, like Salamis-Constantia, Paphos, Soloi, and Polis-Arsinoe, acting as a catalyst for the economic activities of their hinterlands. As I will present the reader with a detailed survey of these and other inland settlements in the following section, I would rather limit the scope of my analysis here to the area around PolisArsinoe, which had been surveyed well before the recent publication of the archaeology of the early and late medieval period in the city. ${ }^{101}$ Parallel to the discovery of an economically vital and frequented city, the idea has been strengthened that the hinterland of the city did not simply reach its peak in the Hellenistic and early Roman periods and drop off abruptly in the later period. At least five (if not more) sites have been proven to have survived into the Byzantine and Medieval eras. ${ }^{102}$ As Caraher and Papalexandrou have further demonstrated, the area around Polis-Arsinoe benefited from coastal access and proximity to overland routes and was characterized by various forms of production, from small-scale industrialization to fishing, agricultural activity, and copper mining, for which Cyprus was well-known in the Hellenistic and Roman periods. ${ }^{103}$

With regard to mining activities, the Polis-Arsinoe hinterland seems not to have suffered from the same fate as Kalavasos-Kopetra. Remains of pressing equipment and copper slags indicate an intensifying village economy that imported table and kitchen wares, amphorae, and roof tiles from different parts of Cyprus and the Mediterranean, possibly in return for agricultural and mining products from the valley. ${ }^{104}$ However, as we have already mentioned, this prosperity came to an end in the second half of the seventh century, when 
the exploitation of the ore located a few kilometres to the north of the village was interrupted. ${ }^{105}$ In contrast, in the area around Polis-Arsinoe (specifically the village of Limne) and Soloi mining activities seem to have survived well into the eighth century and possibly beyond, for the anonymous tenth-century Persian author of the Hadū al-'Álam mentions active silver and copper mines on the island. ${ }^{106}$ Additionally, the Arab geographer al-Idrīsi, although writing in the twelfth century, reports in his Nouzat al-Moushtaq that in Cyprus one could find "metal of al-Zaj", which was exported to many neighbouring and distant countries. ${ }^{107}$ The reference to Zayit al-Zaj, the name coined to define sulfuric acid by the eighth-century Arab alchemist Jābir ibn Hayyān, is intriguing, as the area surveyed by the aforementioned Sydney Cyprus Survey Project - located in the north-central foothills of the Troodos mountains in and around the area of the modern villages of Politiko and Mitsero - had always been known for its copper-sulphide ore deposits. ${ }^{108}$ Indeed, as Papacostas has pointed out, in this area as well as in the district surveyed by the CPSP, slag heaps, archaeometallurgical debris, and ore samples may point to a partial continuity of the mining industry and metal production at least until the end of seventh century. ${ }^{109}$

It is indeed very likely that the economic vitality of the nearby urban centres of Polis-Arsinoe, Soloi, and even Tamassos had been underpinned by the continuity of the link between resilient cities and their countryside, as the seventh-century economic recession and the fragmentation of the eastern Mediterranean exchange network did not uniformly affect all the settled rural areas of the island. ${ }^{110}$ There is evidence that a partially dispersed but coherent settlement pattern emerged as limited not only to the mountainous hinterland but also to the areas along the coasts. Marginal as it may have been, it is possible to picture a differentiated and less uniform Cypriot landscape, which may also have characterized the later centuries well after the supposed caesura of 965 and until a decisive demographic and economic growth took place in the eleventh and twelfth centuries. ${ }^{111}$ In all probability, this landscape was dotted by villages (for instance those on the Karpas peninsula or Agios Kononas) where consistent building and decorative programmes were pursued and supported by medium-small ownership. Moreover, they could boast good level of prosperous elite-owning, as well as pockets of lands affected by an abatement of agriculture and labour intense activities to the advantage of pastoral and semi-pastoral activities (for instance Kalavasos-Kopetra), and more dispersed and isolated settlements (for instance Dhiorios-Kornos Cave). There was no uniform and widespread mass movement of people abandoning the coastal settlements. ${ }^{112}$ There are more than a few traces of human activity in the Cypriot countryside from the late seventh to the ninth century and even beyond. ${ }^{113}$ The proximity to still substantial urban centres is nevertheless the key to approach the issue of rural structures and landscape in a more open and non-catastrophic manner.

It is, therefore, to the cities of transitional Cyprus that I now turn. I am well aware that although cities partially determined the strategies of local land 
investment and patronage as well as local productive-distributive networks as supported by urban-oriented elites, one should not embrace a city-oriented viewpoint focused on the controversial model of a core-periphery. ${ }^{114}$ In other words, we should keep in mind that often the countryside was better prepared than the cities to survive even when facing difficult economic conditions ${ }^{115}$ and even in a landscape where the dramatic changes in the political, administrative, and economic conditions affected patterns of land use, building practices, and local settlement patterns. In the end, urban and rural are inevitably interrelated in the daily life of any society.

\section{Salamis-Constantia and its sisters: Cypriot urbanism in transition}

A full analysis of the trajectories and developments of Cypriot urban centres in the transitional period requires two preliminary remarks. The first has to do with the fact that a proper synthesis of Cypriot urbanism in the period under consideration has never been attempted. Scholars like Dikigoropoulos and Metcalf have compellingly included urban sites in their massive contributions dedicated to Byzantine Cyprus, however in a piecemeal fashion. ${ }^{116}$ In other words, like a ripple effect, presentations of the changes in the medieval face of Cypriot urbanism reverberate into a rather splintered Cypriot urban archaeology. To begin with, the so-called Dark Ages layers and the material evidence have seldom been regarded as worthy of publication, since Cypriot urban excavations have been focused almost exclusively on the classic or Late Antique phases of sites like Paphos, Amathos, Salamis-Constantia, and, more recently, Kourion and Polis-Arsinoe. ${ }^{117}$ Consequently, there are only feeble attempts to identify homogeneous trends and analyse the alterations to urban fabric, plan, and structures in a comparative (especially transMediterranean) perspective.

The idea is that of listing urban centres one by one with a lowest common denominator represented by the almost total collapse of Late Antique urban organization and social and economic life, as cities shrunk and were confined to newly built walled citadels (like Amathos, Salamis-Constantia, and Paphos). Indeed, scholars like Dikigoropoulos, Papageorghiou, Malamut, and Metcalf have repeatedly stressed the decay of Cypriot urban life, which brought about the abandonment of sites like Kourion or the "castralization" of previously prosperous centres like Paphos, Amathos, and Salamis-Constantia, or the ruralization of places like Lapethos, Thamassos, Kythrea, and Tremithos. ${ }^{118}$ As Malamut concludes, "[on Cyprus] the number of urban centres, and above all their monumental fabric and their economic importance, do not allow us to differentiate between cities and villages". ${ }^{119}$ The religious importance of cities as episcopal centres has also been downplayed, for although old titles of cities and names for dioceses were kept and included in the lists of signatories to ecumenical councils, shrines, and bishopric and archbishopric residence could not be regarded as tantamount to the continuity of urban function. The latter conclusion, although based on methodologically sound ground, de facto 


\section{Urban versus rural}

contradicts the supposedly predominant role of the Cypriot archbishop as a main political and ecclesiastical authority on the island, almost unanimously regarded as central to the social and cultural life of the island in the so-called Dark Ages. More importantly, it clearly glosses over the material evidence provided by lead seals and pilgrimage logs, which points to the presence of ecclesiastical hierarchies at Cypriot urban sites in the seventh and eighth centuries.

This "discontinuist" approach to urbanism, which is embedded in a long historiographical tradition, leads me to the second of my introductory observations. Indeed, with few exceptions the demise of Cypriot urbanism has often been directly linked to the supposed havoc wreaked by the Arab incursions. Constant enemy harassment for almost three centuries caused the end of urban settlements, particularly along the coasts, or their transformation into mere rural villages sheltered by hastily built fortifications. ${ }^{120}$ The contribution of Metcalf on Byzantine Cyprus is a good example of this interpretative framework. In the shadow of the walls, only church authorities managed to survive. This imbalance is partially due to the period under scrutiny, as the Dark Age has no documentation, no architectural studies, no archaeology, and almost no coins in circulation. ${ }^{121}$ However, even when a degree of uncertainty is cautiously introduced due to our inability to recognize pottery and the traces of the sub-elite residential foci (often built in perishable material) or when we are presented with puzzling sources, like the eleventh-century Book of Curiosities, cautioning us about the unexpected survival and prosperity of cities like SalamisConstantia, Paphos, and Soloi, we nevertheless meet an unwavering stance: ${ }^{122}$ city life was "moribund". Nothing can resuscitate the Cypriot cities. ${ }^{123}$

Scholars such as Papacostas and Christides have been much more cautious in approaching the supposed demise of Cypriot cities in the transition from Late Antiquity to the early Middle Ages. ${ }^{124}$ Nevertheless, as repeatedly hinted at in the previous chapters, one can seldom escape the impression that the tripartite chronological division surmised by traditional historiography is the foundation supporting a tale of the decline and migration of Cypriot cities. According to this story, it was only after 965 that a totally new urban hierarchy began developing based in the capital Nicosia, the thriving eastern harbour of Famagusta, and fortified hubs like Kyrenia along the northern coast and Paphos and Limassol along the southern coast. ${ }^{125}$

This paradigm of fall and recovery has been reiterated by Megaw in his edited volume on the episcopal precinct at Kourion. Here, however, a detailed analysis of ceramic, numismatic, sigillographic, archaeological, and architectural evidence convincingly led him to conclude that the basilica, built in the early fifth century, only suffered minor damage during the Arab raids. The real catastrophe was an earthquake in the last decade of the seventh century that forced most of the population and the bishop to move, though "only" to the neighbouring village of Episkopi. ${ }^{126}$ The example of Kourion, therefore, should urge us to avoid any dangerous generalization, for even where abandonment and relocation occurred, they had less to do with the supposed 
scorched-earth tactics employed by the invaders than with natural calamities. ${ }^{127}$ Moreover, it should lead us to reconsider the idea of a general relocation of urban life far from the coast. ${ }^{128}$ Episkopi is only two kilometres away from Kourion, and similar events may have occurred at the eighth-century quasiurban Ourania-Aphendrika or rural settlements of the Karpas peninsula (centred upon churches such as Agia Varvara and Aphendrika in Sikhada), which boasted eighth-century churches built a few metres away from the sea. I will return to the latter settlements in the following chapter.

I would like to propose a different approach to the problem of Cypriot urbanism. To do so I will primarily focus on Salamis-Constantia to dispel the validity of the aforementioned interpretative model as mainly based upon primary sources, while at the same time trying to apply the idea of a gradual transition to explain the changes experienced by local urban economic life, material culture, and socio-political structures. In other words, I will use the city as a stalwart hub of a different narrative of Cypriot urbanism. Though the evidence of continuous occupation and its role as a political and ecclesiastical focal point during the entire medieval period are somewhat secondary, most of the history and fate of other Cypriot urban centres connect to Salamis-Constantia's historical trajectory. ${ }^{129}$

The reasons for this are twofold. We possess a relatively large amount of information concerning the city in the seventh, eighth, and ninth centuries due to its political and religious importance. In fact, Salamis-Constantia is often mentioned by literary and documentary sources like eighth-century travel logs, the Acts of the Seventh Ecumenical Council, or Arab geographers, all of which shed some light on the resilience and transformation of its social structure and urban functions. To these one should add the extensive (still partially unpublished) excavation campaigns conducted pre-1974 and focused on both ecclesiastical complexes (like the basilicas of Saint Epiphanios and Campanopetra) and secular buildings (the bath-gymnasium, the late-seventhcentury walls, and the so-called "Huilerie" complex), which were frequented and refurbished in the seventh and eighth centuries and even beyond. In other words, we not only possess good archaeology for the period but also diverse archaeology, revealing a variety of urban functions (administrative, religious, economic, and military structures have been investigated) and plans (excavations investigated different and widespread urban areas).

At the same time, the city puzzles us with an apparently odd methodological jigsaw. The same leg we believed to be healthy - that is archaeology-is instead limping. Indeed, and as previously and repeatedly mentioned, the city has not been studied with modern excavation techniques, methodologies, and methods of interpretation for the last forty years. ${ }^{130}$ This is even more disturbing if we bear in mind how much the wealth of archaeological discoveries has transformed the understanding of conditions in towns in the eastern Mediterranean and beyond in the period under consideration. ${ }^{131}$ In the case of Salamis-Constantia we must circumvent the limits imposed on new excavations by proposing a reassessment of the old material (both published and unpublished) unearthed 


\section{Urban versus rural}

in the surveys dated to the early 1930s, 1950s, and late 1960s. This forces us to move towards a comparative approach encompassing other Cypriot urban settlements like Paphos, Polis-Arsinoe, and Amathos, where punctual and well-published excavations have been conducted during the last decades, "cities on islands" under Byzantine rule like Gortyn in Crete, and, finally, Syria and Palestine during the smooth transition of rule from Constantinople to Damascus. ${ }^{132}$

I am positively convinced this comparative approach will allow me to argue that Salamis-Constantia, like other urban sites in Cyprus, was not destroyed or abandoned, and that the heavy damage often portrayed in the literary sources as caused by the Arabs is a claim completely unsupported by archaeological evidence. Indeed, after the Arab invasions there is evidence of continuous occupation throughout the entire medieval period. ${ }^{133}$ As Papacostas states, urban life and the economy did not change much in the seventh to early ninth century, as the refurbishment of local churches and secular buildings together with the appearance of economically vital structures (such as the artisanal ateliers found in Polis-Arsinoe or the workshops unearthed at the Huilerie complex in Salamis-Constantia and in Paphos) should be interpreted as signs of the vigour of urban communities matched by the role of local elites as patrons. $^{134}$

Salamis was founded in the eleventh century BCE on a plateau perched above a well-protected bay on the eastern coast of Cyprus. The bay encompassed two natural harbours. ${ }^{135}$ Coming from the centre of the island the Pedhios and Yalias rivers (today just feeble seasonal streams) ran eastward across the Mesaoria Plain flowing into the sea immediately to the south of the city. ${ }^{136}$ Notwithstanding the fertility of the Mesaoria (one of the reasons why the city prospered across more than one millennium), marshes could be found at the mouths of the two rivers. These provided the city with an important source of salt, but at the same time caused the silting up of the main, southern harbour, and apparently already in the Hellenistic period the city was endowed with a new northern port. ${ }^{137}$

In the Roman and Late Antique periods the city was hardly mentioned by literary sources, a curtain of silence that was lifted only in the seventh century. ${ }^{138}$ Nevertheless Salamis maintained economic prominence due to its harbour facilities and its strategic location on the eastern coast of the island, allowing it to act as a hub along regional and subregional Mediterranean shipping routes. $^{139}$ The real turning point in the history of the city occurred in 342-43, when, according to the Chronicle of Malalas, a ruinous earthquake hit the entire island, resulting in the almost complete destruction of Paphos. ${ }^{140}$ The same calamitous tremor levelled Salamis and plunged part of the city into the sea. Oddly, Paphos struggled to recover without the aid of imperial patronage. A number of shattered buildings and some entire sections of the city were left in ruins and city life continued almost exclusively at the nearby settlement of Nea Paphos, where both ecclesiastical and secular building activities are documented in the late fourth and early fifth centuries. ${ }^{141}$ 
In contrast, Salamis was endowed with generous donations from the emperor Constantius II (one of the sons of Constantine), who also remitted taxes on the inhabitants for the next four years. ${ }^{142}$ The city was renamed for its benefactor and, henceforth known as Constantia, it became the capital of the island. The renovation supported by the emperor, including the restoration of the bath-gymnasium complex, was meant to bring the city up to the standard of its newly acquired political and administrative functions. The "re-functionalization" of Salamis-Constantia as the governmental hub of the island went hand in hand with its important role as an ecclesiastical centre enhanced by the erection of the aforementioned basilica dedicated to and probably founded by Saint Epiphanios in the late fourth century. Moreover, in the eastern part of the city, an entire new quarter was built around the early fifth-century basilica of Campanopetra, which enlarged an existing monastery dated to the mid-fourth century. ${ }^{143}$ A richly decorated two-story residence with a deliberate "public-character" 144 (the previously mentioned Huilerie complex) was constructed just few metres from the basilica. As we have already seen, this church was one of the many sites of pilgrimage boasted by Salamis-Constantia, together with the basilica of Saint Epiphanios and the church dedicated to Saint Barnabas. The latter was built by Archbishop Anthemios in the late fifth century and patronized by Emperor Zeno to lodge the miraculously discovered body of the saint marking the confirmation of the autocephalic status of the Cypriot Church in $488 .{ }^{145}$

These buildings and the relics they lodged allowed the city to retain its relevance as a well-known stop along the Mediterranean pilgrimage routes in Late Antiquity. Indeed, pilgrims could travel from Cyprus to Antaradus in Phoenicia (four days journey taking them just north of Beirut) and then - via Caesarea Sidon or Tyre - on to Jerusalem. ${ }^{146}$ In 570 Antoninus Placentinus visited the city and was impressed by its fertility and beauty, calling SalamisConstantia a "civitatem pulchram et deliciosam ornatam palmis dactylorum". ${ }^{147}$ Alexander the Monk, writing in the sixth century, noted that the church of Saint Barnabas had buildings for lodging pilgrims around the western atrium of the basilica; this arrangement may have been repeated at Campanopetra. ${ }^{148}$ Therefore, it comes as no surprise that Salamis-Constantia continued to play an important role as a pilgrimage centre well into the eighth century, when Willibald visited the city. ${ }^{149}$

Salamis-Constantia also remained at the heart of imperial interest for the whole sixth century and the first half of the seventh. An inscription noting the basilei agathoi and possibly dated by the lettering style to the first half of the sixth century mentions the restoration of the bath-gymnasium complex. ${ }^{150}$ Moreover, during the turmoil following the coup of Heraclius and the subsequent war against the Persians a mint was established in the city. It operated for two short periods in 609-10 and 629, when large numbers of bronze coins were distributed to the troops stationed on the island. ${ }^{151}$ Sigillographic evidence also points to the centrality of Salamis-Constantia in the local administrative, political, and fiscal structures. This is further supported by the 


\section{Urban versus rural}

extensive building programme staged under the auspices of Emperor Heraclius once the war with the Persians came to an end in 630: an aqueduct taking water from the hills around Kythrea (some 20 kilometres to the northeast) was restored and paired with a large cistern (the so-called Vouta) encroaching onto the northern portico of the agora. ${ }^{152}$ A number of inscriptions referring to the generosity of the emperor embellished the now-lost pillars of the aqueduct. ${ }^{153}$ As already mentioned, the local church also contributed to the restoration programme, as other inscriptions reveal that the archbishops Arcadios (in 628), Plutarchos (in 635-36), and possibly Sergios (in April 640) built a further set of arches. ${ }^{154}$

It is difficult to document a similarly acute imperial and ecclesiastical interest in other Cypriot cities. Difficulties arise both from the dearth of literary sources and the fact that historiography has often focused on those urban centres whose status was acquired in the fourth century and reinvigorated in the fifth and sixth by its bishops. ${ }^{155}$ In other words, the famous fifth-century list of Hierocles mentioning thirteen cities on the island became simply a list of dioceses, which in turn reverberates in the various catalogues of signatures to the church councils on the part of Cypriot bishops and archbishops. All of this is intended to enhance the appearance of a transition from a pagan to Christian city in the same period that eminent theologians like Epiphanios or local saints like Hilarion or Tychon were preaching the holy gospels and trashing idols. ${ }^{156}$ Therefore, it should come as no surprise that in most Cypriot cities archaeological attention has been paid primarily to the fate of urban churches by documenting late fifth- and early sixth-century restorations. ${ }^{157}$

For instance, in Paphos, which Saint Jerome attests was in ruins after the mid-fourth century earthquake but soon recovered, no imperial patronage has been documented but city life continued, with both secular and ecclesiastical building activities on a large scale in the late fourth to early fifth century. ${ }^{158}$ Nevertheless, the only excavated secular building, which supposedly was restored and remained in use until the early seventh century, was the so-called House of Theseus - possibly the former official residence of the Roman governor, endowed with bath and reception rooms. Indeed, the demise of the palatial residence has been interpreted as a clear sign of the triumphal penetration of the church in one of the strongholds of paganism, for Paphos housed a famous temple of Aphrodite. ${ }^{159}$ At least two large basilicas seem to have acted as substitutes for the notorious pagan shrine and to have become important pilgrimage sites: the Limeniotissa and the Chrysopolitissa. ${ }^{160}$ As already mentioned, the latter was an imposing seven-aisle basilica (the largest on the island together with that dedicated to Saint Epiphanios in Salamis-Constantia) remodelled as a five-nave church in the early sixth century. ${ }^{161}$ These churches, as well as others built alongside the street leading from the harbour to the House of Theseus, were regarded by excavators as evidence of a faster pace of conversion from paganism to Christianity although the city seems to have preserved its Hellenistic walls and its classical layout. Unfortunately, however, the excavations at Limeniotissa and 
Chrysopolitissa churches are still awaiting a full and detailed publication, and as Metcalf states:

from the century and a half from 491 up to the Arab invasions ... direct archaeological evidence of the housing of the inhabitants of Paphos or of their economic activity is practically non-existent [as] at least two-thirds of the area within the walls are an archaeological blank. ${ }^{162}$

We encounter a similar situation at other urban sites. This is partially because some centres, like Kition (modern Larnaca), with its church lodging the relics of Saint Therapon, or Kyrenia, set apart from the castle, are still occupied and have been the subjects of little or no excavation. ${ }^{163}$ For other urban centres like Kourion, Carpasia, Ourania-Aphendrika, Soloi, Polis-Arsinoe, and Lapethos, however, archaeological knowledge is at best limited to their main ecclesiastical buildings or their fortifications. ${ }^{164}$

A partial exception is represented by Amathos, located on the southern coast of the island just a few kilometres to the east of Limassol. Here extensive and partially published excavations have focused on the acropolis, the agora, and the lower city around the harbour. The investigations have shed light on two basilicas, one built in the fifth century on the acropolis and the second of a more modest size located in the lower town and acting as the cathedral church. ${ }^{165}$ A third church dedicated to Saint Tychon and dated to the early fifth century has also been discovered outside the seventh-century walls. ${ }^{166}$ Although in Amathos it is still clear that the detailed investigations at the basilica of the acropolis dominates the archaeological work, some light has nevertheless been shed on parts of the lower city's urban fabric. ${ }^{167}$ In particular, excavators have discovered a monumental "administrative" with many different rooms (one of which may have been used as a watch tower) and extensively refurbished after the disastrous mid-fourth-century earthquake. The building shows continuous use well into the seventh century, as it has preserved coins and pottery sherds dating to the reign of Emperor Heraclius. ${ }^{168}$ A bronze pendant was also recovered that appears to have had an apotropaic function. It probably belongs to the so-called Salomon pendant type (because on this kind of object we often find depictions of the legend of King Salomon), the bulk of which came from Syria, Palestine, and Egypt. Although it is often impossible to precisely date these objects, Flourentzos has nevertheless been able to date the well-stratified context in which the amulet was found to the mid-seventh century. ${ }^{169}$

Unfortunately, apart from the amulet and a small hoard of bronze coins dated to the reign of Emperor Anastasius, further details on coins, seals, and inscriptions yielded by the excavations in the lower city are simply unavailable, as they remain unpublished. It is, however, interesting to note that since archaeology in Amathos has focused on a larger part of the urban fabric (rather than just ecclesiastical buildings), it has helped to reassess the traditional interpretative framework adopted to explain the fate of the city in the 


\section{8}

\section{Urban versus rural}

period after the Arab raids. Therefore, we see a departure from the idea that the city did not survive the Arab invasions and that its decline and eventual abandonment left Limassol as the main urban focus of the area. ${ }^{170}$ Although Amathos was impoverished in the mid-seventh century, we can trace some signs of continuing activity. ${ }^{171}$ These are not limited to the fortifications, which were extended down to the sea and probably date to the late seventh century. ${ }^{172}$ Indeed, as Metcalf states: "unequivocal evidence of continued occupation is provided by the common coins of Constans II minted after 653, and (better) by lead seals of the later seventh century and early years of the eighth century". ${ }^{173}$

In my opinion a similar reassessment of the historical trajectory of urbanism after the supposed turning point in the mid-seventh century can be proposed for Salamis-Constantia. Here we are actually on more solid ground, as excavations at different parts of the cities have been published together with a complete catalogue of coins. ${ }^{174}$ Indeed the traditional narrative has often associated the end of Heraclius's reign with the beginning of the end of SalamisConstantia as a fully functional and affluent urban centre. ${ }^{175}$ As previously stated, the Chronicle of Dionysius of Tel-Mahre provides us with a quite vivid description of the sack of the city during Mu'āwiya's first raid against Cyprus. The city fell again in the second Arab raid, after which it was occupied by the general Abu-l-A'war who stayed for forty days and imprisoned the population while eating all the livestock. ${ }^{176}$ Other than these mentions, there is not much written evidence on the fate of the city after the supposed destruction on the hands of the invaders.

The silence of the sources is broken only by the sermons delivered by the archbishop of Constantia during the Seventh Ecumenical Council and Constantine Porphyrogennetos. As I have repeatedly mentioned, the former are not reliable, for they are heavily biased in favour of the iconophile party. As we have seen, the latter, in his De Administrando Imperio, reports only on the transplantation of most of the population of Cyprus to Nea Justinianoupolis led by the archbishop of Salamis-Constantia. ${ }^{177}$ The dearth of primary sources concerning the fate of Constantia has been interpreted by some scholars as tantamount to the end of urban life, when its inhabitants were supposed to have squatted in the ruined buildings and the city changed its name to Ammochostos (i.e., "hidden in the sand"), a term later used to identify the site of medieval Famagusta. ${ }^{178}$ However, we simply cannot find any confirmation of this interpretation in the material sources at our disposal. Indeed, the only evidence implying a violent destruction of residential areas in the city seems to come from the area around the theatre, which had already been abandoned in the wake of the mid-fourth-century earthquake. Here, according to Karageorghis, "small wooden houses built on the ruins of the cavea were burnt down in the mid-seventh century as large deposits of ashes mixed with charcoal have been found on local marmara floors". ${ }^{179}$ However, there is no explanation whatsoever of the justification for dating the destruction layers in such a precise manner. 
A careful reassessment of monumental, ceramic, numismatic, and sigillographic evidence excavated in Salamis-Constantia pre-1974 reveals more than the simple "shot in the dark" of literary sources. First, it helps to refute the idea that the city merely shrank in size and was limited to a walled military stronghold where the archbishop was the dominant political and religious authority. In the same manner, other Cypriot urban centres, such as Paphos, Carpasia, Lapethos, and Amathos, Salamis-Constantia witnessed the erection of a new enceinte sometime in the second half of the seventh century. Although the line of the walls deliberately interrupted one of the main axes of urban circulation (the Cardo Maximus), the fortifications seem to have been neither hastily erected nor poorly built. On the one hand, excavations have revealed that a monumental bent entrance gate (to which I will return later) was constructed at the former intersection of the Cardo and Decumanus, pointing to a careful and deliberate plan to accommodate part of the pre-existing network of roads and, in particular, maintaining the function of the Decumanus as the main thoroughfare leading to the Huilerie complex, the basilica of Campanopetra, and, above all, the harbour. ${ }^{180}$ On the other hand, the analysis of building techniques and masonry composition has led Stewart to conclude that the city walls were contemporary to the restoration of the basilica of Saint Epiphanios; ${ }^{181}$ both were erected in the last quarter of the seventh century and point to a rearrangement of the urban layout, as the main purpose of the enceinte was to protect the cathedral and (possibly) the palatial episcopal complex. ${ }^{182}$

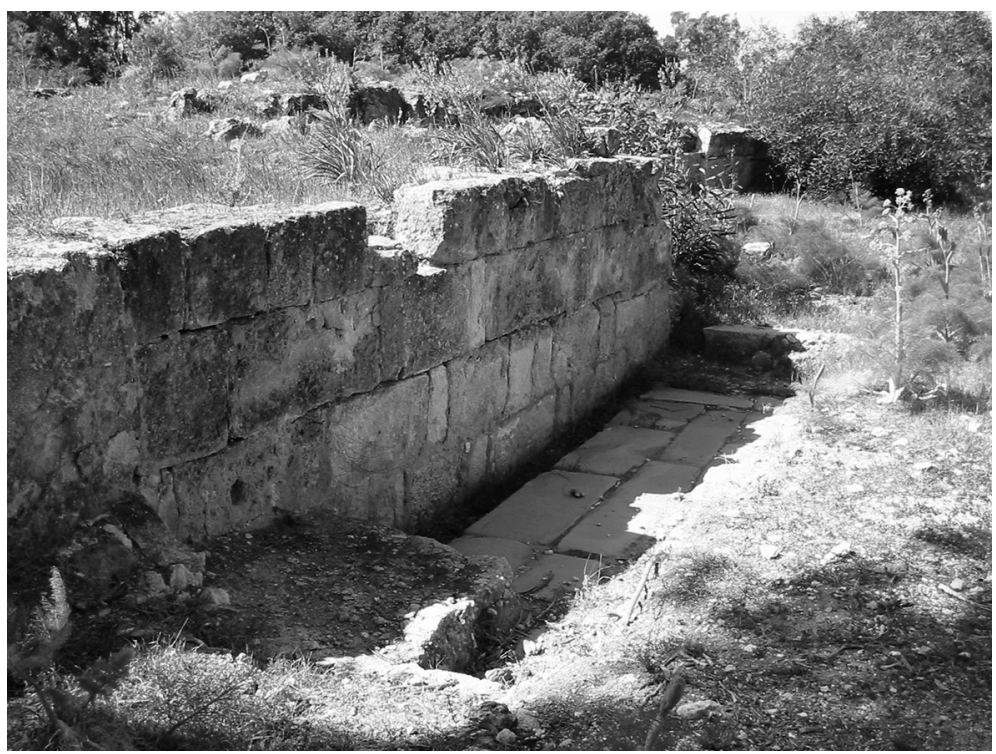

Figure 5.1 Salamis-Constantia: Mid-to-late seventh century walls encroaching onto the Cardo Maximus 
As I have previously stated with regard to Amathos, Salamis-Constantia was not the only Cypriot urban centre where walls were erected in the second half of the seventh century. Historiographers have long debated the function and dating of the ramparts. For instance, in the case of the Salamis-Constantia rampart (possibly the best documented one), diverse and often contradictory opinions abound and have been effectively summarized by Stewart. ${ }^{183}$ In fact, as far back as the1950s Megaw reported that the enceinte could not have been built before 630, since the wall cut through a previous layer containing a coin of the Emperor Heraclius. So he dated the walls to the period after the Arab raids, because he also found burnt material in the mortar. ${ }^{184}$ Dikigoropoulos's excavations in the 1960s yielded an Umayyad coin (an Islamic post-reform fals) above the walls that dated to the first quarter of the eighth century and supposedly indicated that the wall could have been built in the last decade of Justinian II's reign (a theory reiterated by Metcalf and Stewart). ${ }^{185}$ Karageorghis reported that evidence was found pointing to the seventh-century Arab invasions as the main reason for the erection of the ramparts, though he did not state the nature of that evidence. ${ }^{186}$ Eventually, Claire Balandier hinted at the possibility that the walls were erected pre-emptively to guard against the Persians or the Arabs. ${ }^{187}$

A similar hypothesis has also been proposed for the fortifications at Paphos. ${ }^{188}$ Here, the area around the harbour was fortified by incorporating the amphitheatre as a bastion (in a similar way to the so-called Theatre Kastell of Miletus ${ }^{189}$ ) and partially reusing the massive Hellenistic enceinte; its length was abridged, similar to the walls at Constantia. ${ }^{190}$ According to Megaw the walls, which included the Chrysopolitissa Basilica, were erected in expectation of Arab incursions. ${ }^{191}$ A parallel development can be traced in Carpasia, a former Roman city with a substantial harbour located on the northern coast of the Karpas peninsula. The archaeological investigations, directed by Joan Du Plat Taylor in the late 1920s and published together with Megaw in 1981, focused mainly on the basilica supposedly dedicated to Agios Philon, the annexed baptistery, and the bishop's residence. ${ }^{192}$ These buildings remained in continuous use well into the seventh century, when the shrinking harbour town was enclosed with a fortification wall. The enceinte was not fully excavated and attracted but minor attention on the part of the excavators. It was described as:

poorly constructed on two or three courses of rubble foundation or directly upon the rock; faced on either side with cut-stone and possibly reused spolia.... Pottery was recovered from the excavated layer representing the robbing for and the levelling behind the town wall revealed sherds dating to the period of construction and the use of early Christian buildings, ranging from the fourth to the seventh century. ${ }^{193}$

In Lapethos evidence for the erection of walls is almost non-existent. Nevertheless traditional historiography has no doubt that the ramparts encircled the 
area of the basilica and were rebuilt hurriedly and carelessly after $653 / 54$, or even after 648/49. ${ }^{194}$ However, it is not certain that fortifications actually were refurbished in the second half of the seventh century, as the only scrap of evidence is an inscription whose date is far from secure. ${ }^{195}$

We should also question the idea of hastily built fortifications erected in preparation for the Arab raids or the possibility that these new enceintes became redundant after the 686-88 treaty, although originally stemming from a general defensive policy sponsored by the central Constantinopolitan power in the wake of the failed siege of $674 .{ }^{196}$ Stewart has argued convincingly that the fortifications built in Salamis-Constantia, although cutting off the aqueduct and encroaching upon the urban road system, were erected with finely cut limestone blocks plainly manufactured for the endeavour and with little use of spolia. ${ }^{197}$ However, if we move back to Amathos, it is evident that the central gate and at least part of the fortifications around the acropolis underwent restoration after being damaged by an earthquake during the reign of Constantine IV (668-86). ${ }^{198}$ As the enceinte enclosed the fifth-century basilica on the acropolis, which was also refurbished in the same period, the central gate was strengthened by a small barbican similar to that protecting a fortified bridge in Amastris (located on the Paphlagonian coast of the Black Sea). ${ }^{199}$

The comparison is more significant if we take into consideration that in Amastris the fortifications were built piecemeal during the second half of the seventh and the beginning of the eighth century. The barbican (built in the early eighth century) was paired with two monumental gates controlling the main land accesses to the city. One of them is of the so-called baffled or bent gate type, which did not provide a simple or direct opening through the walls. There were two flanking towers projecting from the main curtain and

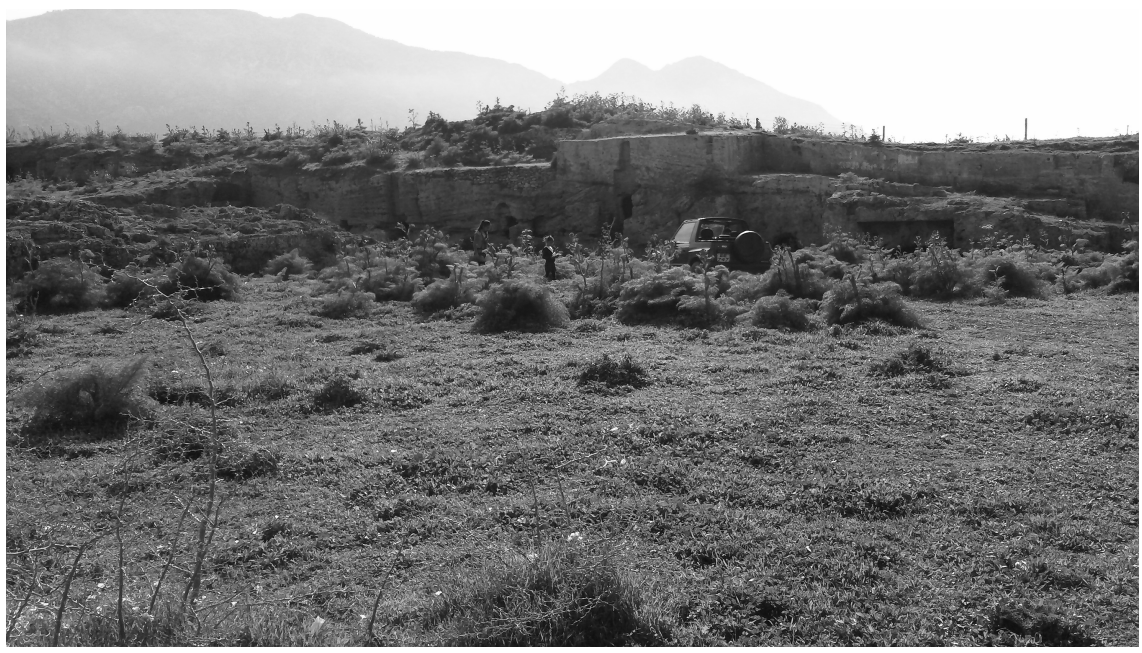

Figure 5.2 Lapethos: Acropolis 


\section{2}

\section{Urban versus rural}

overlooking a rectangular space which could be accessed only from the east side, where the entrance was located. ${ }^{200}$ As previously mentioned, a similar bent gate has been excavated in Salamis-Constantia as part of the late seventhcentury set of walls. ${ }^{201}$ Here we can trace the two rectangular protruding towers and an adjacent square-shaped space accessed via a southern doorway. A further parallel can be found at Kyrenia, where imperial patronage is suspected for two protruding pentagonal towers loosely dated to the mid-seventh century and bolstering the only land access to the castle. ${ }^{202}$ Although, not fully published, the baffled entrance at Salamis-Constantia reminds us of analogous arrangements in Ankara (late seventh century), Amorium (late seventh century), and Kastamonou (seventh to eighth century) and could allow us to assert that the fortifications should be regarded as a major and elaborate defensive work with architectural and ideological purpose, rather than a simple shelter for local inhabitants or the result of a contraction of the Roman and Late Antique city due to the Arab raids. ${ }^{203}$

Indeed, although located in a different region and showing a peculiar set of urban priorities, the examples of Amastris and Ankara should help us to reassess the role and function of the fortifications, which endowed many Cypriot urban centres in the second half of the seventh century. In this light, the enceintes erected in Paphos, Amathos, Carpasia, Kyrenia, and SalamisConstantia should be regarded not exclusively as the result of the newly acquired military and strategic importance of Cyprus in face of the Arab incursions but also as an enhancement of the urban vitality of the cities in the eighth century. This vitality was due to their continuous roles as political, administrative, religious, and economic foci for the local elites and sub-elites.

Moreover, we should consider that some urban settlements across the island remained frequented without development of any sort. Kition bears no evidence of military fortifications (although excavations there are impeded by the buildings of modern Larnaca) and the same applies to Polis-Arsinoe and Ourania-Aphendrika. The former, as will be seen in the next chapter, was located on the western part of the northern Cypriot coast and has presented conspicuous similarities with the urban trajectories documented in SyriaPalestine, with a coherent urban fabric centred on two ecclesiastical buildings and acting as a catalyst for a variety of residential and industrial activities. ${ }^{204}$ Ourania-Aphendrika, lying along the north-eastern coast of the Karpas peninsula, was overlooked by an acropolis and boasted two churches (Asomaton and Panagia Chrysiotissa), which, as stated in the previous section, Stewart has identified as barrel-vaulted and convincingly dated to the early eighth century. Both churches have high quality masonry with decorative accoutrements that the other ecclesiastical buildings across the Karpas peninsula lack. ${ }^{205}$ As one of the churches lay in the vicinity of a subterranean shrine, it is possible that one of the reasons for the continuity of OuraniaAphendrika (in addition to its harbour) was its importance as a pilgrimage centre. But only future excavations will shed light on other urban structures, 
which can today only be surmised by the large amount of pottery sherds spread across the entire area from the coast to the acropolis. ${ }^{206}$

If one accepts that fortifications cannot be regarded as the only litmus test for the survival of a supposedly diminished and reduced urban life, it should also be clear that the existence of walls does not imply that the urban fabric and social structures were heavily militarized and therefore limited to the intra-moenia area. A brief comparison with Gortyn on the island of Crete will be useful here. In fact, archaeological excavations have shown that the city which remained the main political and religious focus of Byzantine Crete until the late eighth century - preserved a complex social and demographic structure, a vital economic life, and political and religious importance in the seventh and eighth centuries. ${ }^{207}$ As Zanini and others argue, the Arab expansion across the eastern Mediterranean did not impact the economic life of Cretan urban centres like Gortyn and Eleutherna, which were to experience instead a slow process of abandonment and ruralization only in the course of the ninth century. ${ }^{208}$ Until then, as showed by ceramic, sigillographic, and numismatic evidence along with archaeology, Gortyn seems to have retained a multifunctional imago urbis with different foci of settlement developed both intra and extra- moenia until frequentation gradually faded between the end of the eighth century and the beginning of the ninth. ${ }^{209}$ In the mid-seventh century the acropolis was enclosed by a new set of fortifications, while at the same time other areas of the urban landscape also maintained a level of coherence (though certainly looser than in the Late Antique period) in terms of fabric and morphology, although revealing the first traces of a changing type of urbanism (of the so-called "city of islands" model). ${ }^{210}$ Moreover, excavations have revealed that an entire quarter of the city (the Byzantine Houses complex) was turned into an artisanal and commercial quarter, which remained vital until the first decades of the eighth century and may bear some resemblance with the structures unearthed in Polis-Arsinoe. ${ }^{211}$

With the example of Gortyn in mind, one could propose similar trajectories for the urban fabric, social structures, and economic activities of SalamisConstantia and other Cypriot cities. In the Cypriot capital, for instance, we can demonstrate that the two main basilicas of Saint Epiphanios and Campanopetra were restored. The former was abandoned in favour of a more modest church contemporary with the fortifications and built off the southeast corner of the monumental original structure, whereas the latter continued to be frequented until the early eighth century, as shown by the refurbishment to its annexes and numismatic evidence. ${ }^{212}$ It is possible that at least for some time the importance of both churches was stimulated by the role of the archbishop, who continued to reside in the city and maintained a regular correspondence with its suffragans (as revealed by the lead seals of the seat of Constantia found in seventh- and eighth-century layers across Cyprus). ${ }^{213}$ The churches may also have been among the sites visited by pilgrims like Anastasios Sinaite, Willibald, and Epiphanios the Monk, who visited the city in the eighth and ninth centuries. 


\section{Urban versus rural}

Moreover, in Salamis-Constantia we can point fairly continuous economic functions as underpinned not only by the members of the high clergy, but also by high and middle ranking officials. This is confirmed by the aforementioned array of lead seals, which attests to the presence of various administrative officials including Theodoros, Imperial Spatharios and Strategos of the Theme of the Kibyrrhaiotes, whose seal is dated to the early eighth century. ${ }^{214}$ The presence of members of the military and fiscal machinery seems further shown by an inscription (now completely vanished) on a column of the bathgymnasium mentioning a Constantine Comes and dated to the late seventh to early eighth century. ${ }^{215}$ It is indeed interesting to note that the epigraphic evidence could be related to a contemporary partial restoration of the building. This included the refurbishing of two edicules in the northeast and southeast corners of the open court and the laying of a new the opus sectile pavement, both datable to the end of the seventh century to the beginning of the eighth century using coin evidence. ${ }^{216}$

The presence of vital military, ecclesiastical, and also civilian local hierarchies (such as the previously mentioned phangoumeneis) indicates an urban fabric and social activities not at all hemmed in the intra-moenia space. To the restoration at the bath-gymnasium one should add evidence of a late seventhto early eighth-century artisanal phase of occupation at the Huilerie complex. This was a large household spread across an insula of the Late Antique city plan. It was organized around a central court and built in the early fifth century just few metres away from the basilica of Campanopetra. Lavishly covered in stucco decoration, the complex also boasted an inscription celebrating Epiphanios, possibly pointing to an ecclesiastical function. ${ }^{217}$ During the late seventh to the beginning of the eighth century, the main building was partitioned and occupied by three separate two-story buildings: the first with an external portico, the second focused on a central court, and the third expanding beyond the limit of the complex. Two of these buildings also presented an upper floor developed only along the external front of the original insula. $^{218}$ The new buildings revealed at least one workshop with an olive press (giving the whole complex its name), some bread ovens, and lime. ${ }^{219}$ Here a possible comparison can be made not only with the aforementioned structures excavated in Gortyn and in many urban centres of Syria and Palestine - like Pella, Schytopolis, or Jerash, where archaeological evidence uncovered in the last few decades has revealed an almost explosive growth of industrial activities within towns - but also with other Cypriot sites. ${ }^{220}$

It would be only too easy to once again refer to the recently documented area of Polis-Arsinoe. However, artisanal and commercial activities in urban space are also documented in Amathos, where workshops and residential buildings were erected around the basilica on the acropolis, as well as in Paphos. $^{221}$ In the former Roman capital of the island a number of small houses and simple workshops (in active use from 680 to 780) were uncovered in the area of the former Roman forum and around the basilica of Chrysopolitissa. The latter was indeed refurbished in the eighth century, receiving a new apse 
on the axis of the original basilica, whereas the Panagia Limeniotissa was rebuilt on a smaller scale and in accordance with the barrel-vaulted type. ${ }^{222}$ Evidence of building activity in Paphos tallies both with the continuous role the city and its harbour played in the pilgrimage route, for in 723 Willibald landed at Paphos and spent Easter there before moving to Salamis-Constantia. As already mentioned, a new enceinte was built sometime in the late seventh century, but evidence of extramural residential quarters also exist: houses were built around Panagia Limeniotissa, as shown by the above-mentioned funerary kufic inscriptions dated from the late seventh to the late eighth century and referring to Arab soldiers, administrators, and possibly merchants. ${ }^{223}$ As will be seen in the next chapter, the economic vitality of Paphos is further enhanced by the ceramic evidence, Islamic seals, and by the eighth- to ninthcentury glass factory discovered in the Saranda Kolones area. ${ }^{224}$ Therefore, there is no reason to believe that the city was irreparably destroyed by the Arabs forcing the local population to leave. Material indicators all point to continued urban life supported by the persistence of urban-oriented elites. In tune with the latter conclusion, Metcalf has proposed a reassessment of the archaeology and material evidence yielded at Paphos. ${ }^{225}$ By focusing on the topographic differences within the urban site and by analysing in particular the coinage found in the northern agora and at the waterfront (Saranda Kolones), Metcalf concludes that Paphos remained commercially active, notwithstanding the lack of specimens dated to the second half of the eighth century. $^{226}$

It is clear that early medieval Cypriot cities like Amathos, OuraniaAphendrika, Paphos, and Salamis-Constantia were poorer than their predecessors. Nevertheless, urban functions and urban activities seem to have survived in Cyprus with no real collapse leading to frenzied reuse and pillage of Late Antique edifices. Local landowners, ecclesiastical hierarchies, and administrative and military elites still lived in cities and did not abandon them for the countryside. They continued to support an essential level of coherence in urban plan and fabric. Moreover, one could even propose that urban-oriented and still powerful local landowners helped to extend this architectural typology to portions of the countryside where they still retain sound economic interests. This would explain, for instance, why two eighthcentury barrel-vaulted churches (Panagia Aphendrika in Sikhada and Agia Varvara) could be found just a few kilometres away on the fertile plain of Galinoporni-Kaleburnu in the Karpas peninsula, as one dominated a small and fertile stretch of land and the other was just a few metres away from the coast and visible from the sea. ${ }^{227}$ Indeed, a similar settlement pattern has been proposed for the Balearics, where, according to Cau Ontiveros and Mas Florit, small basilicas rebuilt or refurbished in the hinterland during the eighth century were "parishes as well as productive areas that exploited the resources of the territory and were interconnected with other sites in their surroundings, while the coastal examples were more likely to be linked to port communities and their activities". ${ }^{228}$ It is possible then to surmise that while 
cities were weakening, elites (ecclesiastical and secular) maintained pockets of predominantly local land-based wealth. By the same token, it would also be possible to assert that the foundation of the power of Cypriot elites was, at least to some extent, a mixture of land-ownership and control of the government to be exerted from the surviving urban centres well into the eighth century.

What happened to Cypriot urban (and rural) life after this date is very problematic. As I will return to this issue in more detail in Chapter 7, in the next few lines I will only give some preliminary remarks in tune with the problems of urban and rural settlement. Indeed, Papacostas and Veikou have recently dwelled upon the meaning of the relocations of the Cypriot capital, and in particular on the waning of Salamis-Constantia in favour of the inland site of Nicosia in the second half of the ninth century. ${ }^{229}$ Moreover, as already mentioned, Cosentino has pondered the economic vitality and socio-political resilience of elites inhabiting the Byzantine islands, identifying the turning point as the Muslim conquest of Crete and Sicily in 824 and $827 .^{230}$ Cyprus was also targeted by Muslim incursions, but it is in my opinion that it is more important to contextualize the political and economic role of the island within a larger "insular" trend of more scattered rural landscapes and settlement pattern and the retrenchment of urban life towards the interior. This is all gleaned by considering local topographic diversities. In other words, there is no need to theorize a catastrophic flip or to mark 965 as the turning point for a sudden change in the ninth- to eleventh-century organization of agricultural production, settlement patterns, and commercial activities. As Veikou surmised, relocations of important urban settlements like the capital were linked to political changes, so that economic exploitation and the settlement system was determined in large part by the political system in effect. In the case of Cyprus, this system seldom changed until the second half of the tenth century. ${ }^{231}$ As Cosentino concludes:

The probability that Constantia still exercised a role as residence of the central authority of the island in the ninth century or the diffusion map of CRS among Byzantine and Muslim territories may suggest not alternative but parallel explanations for the changing life in eight [to tenth] century Cyprus. $^{232}$

And indeed the relocation of the Cypriot capital from Salamis-Constantia to Nicosia, far away from the coast, owed less to the instability of the seventh and eighth centuries but rather to the slow changes in the connectivity of the Mediterranean basin in the second half of the ninth century as well as to the long-term effects of the return of the islands to Byzantine control in the late tenth century. ${ }^{233}$

In this light, as Zanini has pointed out, it is important to consider the osmotic and variable relations between city and countryside in terms of migrations of rural population to the city when urban elites retained their role as main socioeconomic actors and catalysts for commercial and artisanal 
activities. ${ }^{234}$ Areas of empty landscape could nevertheless be interspersed with regions (like the Karpas peninsula in the case of Cyprus) where local landowners used small villages or farmsteads focused around rural churches to link their possessions to the communication routes. By the same token, poorly built, architecturally de-monumentalized, and demographically diminished cities could remain, nevertheless, the core of persistent urban economic activity sitting next to areas where there were concentrations of religious buildings and others where military or administrative state-driven institutions resided, as reflected by the proposed city of islands model. ${ }^{235}$ Indeed, it is true that what appear to be islands of urban settlement could instead stem from the quite dispersed nature of archaeological research in urban environments. But it seems to me that this interpretative model of urban development in the age of transition dovetails with types of material evidence other than monumental and building structures

Pottery, in particular, has been reassessed in recent years and has revealed a degree of previously unsuspected economic vitality on Cyprus in terms of production, demand, and distribution of ceramics (as well as other goods like glass). In turn, this model would also fit with the more decentralized and flexible political structures of Cyprus as a middle ground between the Byzantines and the Umayyads. The monumental deterioration and spatial de-structuring, symbolic of the more formally defined Late Antique elites, is here reinterpreted in the light of persistent urban economic activities reflecting informal urban aristocrats. This brings the urban life in Cypriot urban centres a step closer to Syria-Palestine where, as Walmsley argued, different levels of economic activity reflected differences in townscape and city planning, as markets operated within diverse and complex systems of exchange and cultural interaction. ${ }^{236}$ It is in this diversity and not in a complete catastrophe that the key to reinterpreting the trajectories of the cities of Cyprus in the transition from Late Antiquity to the early Middle Ages may lie, especially if and when archaeology, or the trowel, to quote Metcalf, will be allowed again not to lie. ${ }^{237}$

\section{Notes}

1 Given and Knapp (2003), 252. For a complete inventory of the intensive and extensive rural surveys that have been conducted on the island, see Stewart, Davis, and Weyl Carr (2014), Rautman (2005) and Papacostas (2001).

2 I am referring here, for instance, to the well-known excavations in the area of the basilica of Saint Epiphanios and the survey of the so-called seventh-century walls by Dikigoropoulos in the 1960s and never published. See Stewart (2008), 63-85 and Zavagno (2014).

3 Dikigoropoulos (1961), 200ff.; Karageorghis and Maier (1984); Karageorghis (1969); Megaw (2007); Papageorghiou (1993); Metcalf (2009), 269-300;

4 Stephen of Byzantium (2006, Billerbeck), passim); Hieroclis Synecdemus 706-7 (1939, 49-70); George of Cyprus 1095-1110. The list included Constantia, Kition, Amathous, Kourion, Paphos, Arsinoe, Soloi, Kirboea, Lapethos, Kyrenia, Thamasos, Kythrea, Tremithos, and Karpasia. On Nicosia see the contribution of Papacostas (2012). 
5 Metcalf (2009), 346-9.

6 For a full survey of the contributions of these authors see Zavagno (2009), 1-30.

7 The best and most consistently published are the Sydney Cyprus Survey Project, focused on the Mitsero-Politiko area: Given and Knapp (2003), 77-93; the Kalavasos-Kopetra Survey: McClellan and Rautman (1995); Rautman (2003); and the Canadian Palaeopaphos Survey Project: Rupp and Sørensen (1993).

8 McClellan and Rautman (1995), 85; see also Rautman (2001); Rautman (2005).

9 Dikigoropoulos (1961), 263.

10 Fejfer (1995), 86; for eastern part of the Kyrenia range (within the triangle Trikomo-Lebadia-Akantou) see Papacostas (1999), 32-4.

11 Gregory (2003). Fejfer (1995), 175; also Armstrong (2006), 21-4; Rautman (2014), 52; and Randall (2013), 276-9.

12 Athanassopoulos (2010), p. 257.

13 Papacostas (1999), 30.

14 Veikou (2015b), 362-9.

15 Gregory, (1987), 200.

16 Randall (2013); Armstrong (2006); Armstrong (2009); Vroom (2012b)

17 Fejfer and Hayes (1995); Rupp (1981); Fejfer and Mathiesen (1992).

18 Parani (2014), 136 with further bibliography.

19 Wickham (2009), 348-72.

20 Foss (2010).

21 See, for instance, the recent contribution of Demetris Michaelides on the site of Agios Pente of Yeroskipou (Michaelides 2013a).

22 Parani (2014), 133.

23 Wickham (2005), 436-7.

24 Ibid., 434-40.

25 Walmsley (2007), 112. See also Taxel (2013b).

26 Walmsley (2007), 71-112; Taxel (2013a); on Cyprus there is not enough archaeology to retrieve that kind of data.

27 Koder (2012), 173.

28 Given and Knapp (2003), pp. 285ff. Here one must stress that the chronological time-span (550-650) the excavators propose is determined almost exclusively by the chronology of fine wares, although as we have seen this is detrimentally affected by the lack of analysis of locally produced coarse wares.

29 Catling (1972); Catling and Dikigoropoulos (1970).

30 Zavagno (2011-2012), 148, 152.

31 Zanini (2007), 30-2.

32 Walmsley (2007), 71.

33 Papacostas (1999), 9-44; Rautman (2003), 247ff; Dikigoropoulos (1961) $200 \mathrm{ff}$ (the latter should be regarded as a oldie-but-still-goodie contribution, for it includes unpublished material excavated or examined by the author himself); Metcalf (2009), 269-301, 425-99. To overcome this problem, the reader could consult the website of the Department of Antiquities of the Republic of Cyprus, which provides a sometimes up-to-date list of the excavations under way on the island: http://www.mcw.gov.cy/mcw/DA/DA.nsf/DMLexcavat_en/DMLexcavat_ en?OpenDocument (accessed 1 June 2014).

34 A digitized version of the map is now available at http://www.euratlas.net/carto gra/peutinger/ (accessed 1 June 2014). The so-called Peutingerian Table in fact is a map dated to the fifth century and regarded as "the most representative piece of cartography of the Roman era. A sample of Roman itineraria scripta, a cartographic type of geographic and military character, which was popular in ancient Rome, it depicts thoroughly the ancient Roman road network from the Iberian Peninsula to the Middle East, surrounding the Mediterranean Sea" (Pazarli (2009), 101). Bekker-Nielsen (2004). 
35 Pazarli (2009), 109. Also Mitford, (1980), 1333-37; also Papacostas (2001), 111.

36 Ibn Khurdādhbeh (1967, 112); al-Muqaddasī, Kitāb Ahsan al-Taqāsim fì Ma rifat al-Aqātim, in Cobham, in Excerpta Cypria (1908), 5. See also Christides (2006), 5-8, and Mansouri (2001), 27-58 (which quote a passage from al-Fīdā's Tarikh).

37 Megaw (1959), 25.

38 Hieroclis Synecdemus 706-7 (1939, 49-70).

39 Catling (1972); Catling and Dikigoropoulos (1970).

40 Catling (1972), 5.

41 Ibid., 79. On the coin see also Metcalf (2009), 202 and Armstrong (2006), 22-3.

42 Catling (1972), 66. See also Armstrong (2006), 21-4; Armstrong (2009), 165; Papacostas (1999), 29.

43 Rautman (2003), 249; Armstrong (2009), 166-7; Randall (2013), 278. See also Haldon (2012a) and Haldon (2012b), 4.

44 Armstrong (2009), 165; Catling and Dikigoropoulos (1970), 56-7. Also Stewart (2008), 74; Dikigoropoulos (1961), 324; Rautman (1998), 84; Megaw (2007), 437; and Rautman (2003), 175 with further bibliography.

45 Megaw (1959), 25.

46 Catling (1972), 80.

47 Papacostas (1999), 32-4, 58.

48 Zavagno (2011-2012), 146; Papageorghiou (2011), 358-9.

49 Soteriou (1931), 484; Papageorghiou (2011), 222-30.

50 Rautman (2003), 2

51 Stewart (2010), 182; Stewart (2008), 51-60.

52 McClellan and Rautman (1995), 85.

53 Rautman (2003), 249. For Phlamoudhi see Smith (2005).

54 Rautman (2014), 44. Also Rautman (2005), 458-9.

55 Stewart (2010), 183.

56 Zavagno (2014).

57 For Kalavasos-Kopetra, see Rautman (2003) with further bibliography; for Alassa see Flourentzos (1996); for the Akamas region, Fejfer (1995) with further bibliography. See also Papacostas (1999), 36ff.

58 Rautman (2003), 55-179; Rautman (2001), 249-56.

59 Ibid., 90-1.

60 Flourentzos (1996), 36-7.

61 Lécuyer and Michaelides (2004); Lécuyer (2002).

62 Fejfer (1995), 16.

63 Leonard (1995).

64 Bakirtzis (1995), 247-53. Also Bakirtzis (1997); Bowersock (2000), and Veikou (2015a) 49-50.

65 Bakirtzis (1995), 251.

66 Fejfer (1996), 83.

67 Ibid., 79.

68 Varinlioğlu (2007).

69 Ibid., 314.

70 Ibid., 312-17.

71 Vanhaverbeke and Waelkens (2003).

72 Vanhaverbeke et al. (2009), 178.

73 Ibid., 184-8.

74 Armstrong, (2006); Akyürek (2006).

75 Armstrong (2006), 26.

76 Veikou (2015b), 368.

77 Metcalf (2004), 57-62; Metcalf (2009), 372-3.

78 Zavagno (2009), 457, 464. Metcalf (2004), 60.

79 Metcalf (2009), 90, 118. 
80 For the seals of the metropolitan and the deacon, see Metcalf (2004), 386-7 (n. 489-90). For the supposed exile of the Tyrian ecclesiastical authorities to Cyprus, see Metcalf (2009), 91.

81 Metcalf (2009), 116-18.

82 Agapius of Manbij (1912, 481): "he [Mu'āwiya] returned to Syria and besieged Aroud [Aradus], employed all his efforts there, but could not take it. He then sent a bishop called Thomas, who asked the inhabitants of the town to leave the island and to go away to Greece so that the Arabs could settle there. When the bishop arrived there, they imprisoned him, did not let him return to Mo'awia and did not pay any attention to his message. Then Mo'awia returned to Damascus, because winter was arriving and that it was to the sea. After the winter and at the beginning of spring, Mo'awia returned to the island of Aroud with troops stronger and more numerous than the first. He besieged it and treated the inhabitants with harshness."

83 Conrad (1992), 344-5.

84 Metcalf (2004), 525 n. 725.

85 Kennedy (2010), 187; Hirschfeld (1997).

86 Molinari (2013), 104.

87 Ibid., 105.

88 McCormick (2001), 506ff.

89 See Life of Saint Demetrianos (1907), 232-3. According to the text, Saint Demetrianos was the son of a village priest in Sykae who later became the Bishop of Chytroi (Kythrea) some twenty-five kilometres northwest of SalamisConstantia. Charles Stewart has proposed identifying Sykae with the settlement of Sikhada, where a barrel-vaulted church (Panagia Aphendrika) has been surveyed (Stewart, "The First Vaulted Churches," 171-2. See also Ryden (1993).

90 Dikigoropoulos (1961), 255.

91 Ryden (1993), 201.

92 Papageorghiou (1993), 41; Koztakoğlou (2005), 591-3; Papageorghiou (2011), 34 40; Rautman (2014), 45. For the church of Saint Mavra at Chrysocava, see Megaw (1974), 80, and Papageorghiou (2011), 192-200.

93 Toumazou, Kardulias, and Counts (2011), 36.

94 Rupp (1987). The quotation is from Gregory (1987), 200.

95 Metcalf (2013a), 74.

96 This may have to do in part with the fact that Cypriot rivers have often dried up as extensive irrigation and human consumption have taken their toll and rendered them invisible, silent, and empty paths wriggling their way across the Mesaoria plain.

97 Papacostas (1999), 34.

98 Dikigoropoulos (1961) 257-8. The only short, published report is Catling (1982).

99 Megaw (1958), 43.

100 Toumazou, Kardulias, and Counts (2011), 69-208.

101 Caraher and Papalexandrou (2012); also Caraher, Moore, Olson and Papalexandrou (2013).

102 Rautman (2003), 249.

103 Caraher and Papalexandrou (2012), 279. On the importance of the Cypriot copper mining industry, see Dikigoropoulos (1961), 270; Papacostas (2001), 111; and Papacostas (1999), 75 with further bibliography.

104 Rautman (1998), 87. Also Rautman (1999), 377, and Rautman (2001), 254.

105 Papacostas (2001), 112.

106 Papacostas (1999), 75, and Papacostas (2013); also Minorsky, (1937), 59.

107 Al-Idrīsi in Cerulli (1970-1975), 643). Translation from Italian to English is mine. See also Mansouri (2001), 39, and Christides (2006), 5.

108 Kraus (1962), 357-9 with further bibliography. 
109 Papacostas (1999), 75.

110 Stewart (2010), 184 with further bibliography. See also Papacostas (1999), 34-5.

111 Papacostas (2013), 182-90.

112 Dikigoropoulos (1961), 263.

113 McClellan and Rautman (1995), 86.

114 Varinlioğlu (2007), 288; Zanini (2009a), 111-13.

115 Ibid., 316.

116 Dikigoropoulos (1961), 200-46; Metcalf (2009), pp. 269-300.

117 On Paphos, see Karageorghis and Maier (1984) and Metcalf (2013a); on PolisArsinoe, see Caraher and Papalexandrou (2012) and Caraher, Moore, Olson and Papalexandrou (2013); on Amathos, see Pralong (1994) and Aupert et al. (20032004); on Salamis-Constantia, see Zavagno (2014); on Kourion, see Megaw (2007).

118 Metcalf (2009), 490.

119 Malamut (1988), 286 (the translation from French is mine).

120 Metcalf (2009), 490-5.

121 Ibid., 490.

122 "The Book of Curiosities" (Kitāb Gharā'ib al-funūn wa-mulah al-'uyūn, or The Book of Curiosities of the Sciences and Marvels for the Eyes) is a thirteenth-century Arabic manuscript recently acquired by the Bodleian Library in Oxford that copies an eleventh-century version and may repeat some even earlier information dated to the ninth century. It shows different maps of the islands of the Mediterranean, including Cyprus and its main harbours (Salamis-Constantia, Lapethos, Paphos, Kition, and Soloi, among others) and provides us with invaluable details on the social life, trade, and culture of the Muslim and Christian inhabitants of the Mediterranean. See Rapoport and Savage-Smith (2010), and Metcalf (2009), 508-11.

123 Metcalf (2009), 494.

124 Papacostas (1999) and Christides (2006).

125 On Nicosia, see Papacostas (2012) and Dikigoropoulos (1961), 243-5; on Famagusta, see Walsh, Kiss and Coureas (2014); on Kyrenia, see Dikigoropoulos (1961) 237, and Petre (2012), 231-55 with further bibliography; on Paphos, see Karageorghis and Maier (1984); Megaw (1988) and Petre (2012), 313-71; on Limassol, see Papageorghiou (1993), 35 and Petre (2012), 273-98.

126 Megaw (2007), 561.

127 Dikigoropoulos (1961), 249.

128 Veikou (2015a) and Veikou (2015b).

129 Papageorghiou (1993), 50-1; Zavagno (2011-2012), 144-52.

130 Notwithstanding the current ban on archaeological digs (see on this Harpster, "Maritime Archaeology"), excavations have been conducted in SalamisConstantia by the University of Ankara; some preliminary results have appeared in the journal of the Archaeology Department (AnadolulAnatolia). See for instance Öztaner (2007) and Özgünel (2007).

131 Walmsley (2007), 76; Magness (2010).

132 On Paphos, see Karageorghis and Maier (1984); on Polis-Arsinoe, see Caraher and Papalexandrou (2012); on Amathos, see Pralong (1994) and Aupert et al. (2003-2004). On Gortyn, see Zavagno (2009), 35-90; Zanini (2009a), Zanini (2013a) and Baldini et al. (2012).

133 Papageorghiou(2013), 50-1; Zavagno (2011-2012), 144-52.

134 Papacostas (1999), 208-11.

135 Pouilloux (1966), 235. According to myth the founder of the city was the Trojan hero Teukros, son of Telamon, the king of the island of Salamina in the Saronic Gulf (Greece). The city succeeded prehistoric Enkomi (whose ruins are still visible to the northeast) and flourished during the Geometric period. In the Archaic and 
Classical periods, Salamis extended seaward, north of the Geometric settlement, in a larger area around the port and became the most important city of Cyprus. This northward movement may have been due to the gradual silting of the southern harbour by the river's sediments, thus forcing the inhabitants to move to the area around the northern anchorage. See also Karageorghis (1969), 13-15.

136 For a detailed description of the geography and morphology of the island, see above

137 For an overview of the history of Salamis's harbours, see Flemming (1974), 163-4, and Avner (1995), 162-3.

138 Mitford (1980), 1295; Papacostas (1999), 107.

139 Karageorghis and Maier (1984).

140 Malalas XII. 313 (Jeffreys, Jeffreys, and Scott 1986, 170). However, seismologists contest the fact that sea-waves were actually caused by the earthquake (see Ambraseys 1962, 899).

141 Karageorghis and Maier (1984), 285-6.

142 Malalas, XII. 313 (Jeffreys, Jeffreys, and Scott 1986, 170).

143 Roux (1998). The modern name (Campanopetra) is a corruption of the Latin for "field of stones" or "stone-ring-bell" (as a pinnacle of its ruins resembling a bell tower protruded from the sand hills covering the site before it was excavated). On the monastery, see Megaw (2006), 394-405.

144 Argoud, Callot, and Helly (1980), 49.

145 On the miracle and its political and ecclesiastical inferences, see Zavagno (20112012), 136-8, with further and detailed bibliography. Also Bowersock (2000), 18; and Chapter 4, n. 251

146 Wilkinson (1977), 37.

147 Itinerarium Antonini Placentini $(1977,35)$.

148 Alexander the Monk, Laudatio Barnabei Apost., IV, 44-6, quoted in Chavaud and Yon (1978), 18-20. Roux (1998), 236-7.

149 Hugeburc, Vita Willibaldi 1-2, (1954), 161.

150 Metcalf (2009), 175. Megaw, who first documented the inscription, dated it to the first half of the sixth century due to "structural indications that the bathgymnasium was substantially rebuilt in this period [as also] the stoae of the palestrae were reconstructed with marble colonnades" (Megaw 1959, 31). Moreover, an opus sectile floor similar to that embedding the inscription was found in Antioch and dated to 537. Dikigoropoulos, instead, prefers to date the inscription to the late seventh century, as the last rebuilding phases of the complex are indeed dated to Constans II and Constantine IV's reigns (Dikigoropoulos 1961, 22). See also Stewart (2016), 7.

151 Zavagno (2014), 454-8 with further bibliography.

152 On the aqueduct see also Papacostas (2014), 81.

153 Sodini (1988), 619-34.

154 Mitford (1950), 124. Sergios was also the author of an anti-Monothelite letter sent to Pope Theodore in 643 and read to the Lateran Council in 649 (Pohlsander 2006, 63). See Chapter 4 n. 266.

155 Metcalf (2009), 352.

156 The Life of Saint Tychon, written almost two centuries after his death, reports that after he became bishop of Amathos "he smashed the image of Aphrodite since a ceremonial procession in her honor passed close to [his] holy church. Subsequently he converted and baptized after having converted them to their mistake, the [local] pagans" (Delehaye 1937, 230).

157 Papageorghiou (1993), 34.

158 Karageorghis and Maier (1984), 291-5; Jerome, Vita Sancti Hilarionis Eremitae, in PL 23, 42.0051B: "Paphum, urbem Cypri, nobilem carminibus poetarum, quae frequenter terrae motu lapsa nunc ruinam tantum vestigis quid olim fuerit, ostendit." 
159 Megaw (1988), 143. Also Dikigoropoulos (1961), 228.

160 See Chapter 3 n. 181.

161 Megaw (1988), 139.

162 Metcalf (2009), 283.

163 For Kition, see Papageorghiou (1993), 38-9, and Dikigoropoulos (1961), 219; for Kyrenia, see Megaw (1964); Megaw (1985), 210-14; Metcalf (2009), 265; and Papacostas (2012), 82-3; also Petre (2012).

164 See Papageorghiou (1993), 37ff, Papageorghiou (1986), 491ff., and Dikigoropoulos, (1961), 221ff.; see also Papageorghiou (2011), passim.

165 For the first church, see Pralong (1994); for the second one, see Metcalf (2009), 290. Also Aupert (2000).

166 For the memory of the saint, see Papacostas (2014), 197-8.

167 Metcalf (2009), 291.

168 Christou (1996), 1068; Christou (1997), 904; also Rautman (2014), 46-52.

169 Flourentzos (2002), 367; also Metcalf, (2009), 317.

170 On Limassol, see the recent contribution of Papacostas (2015) that I was unable to include in the current chapter due to its later publication.

171 Metcalf (2009), 289.

172 Dikigoropoulos (1961), 220; Aupert (2008). See also Balandier (2002b), 181.

173 Metcalf (2009), 289.

174 Callot (2004).

175 Metcalf (2009), 421-2.

176 Dionysius of Tel-Mahre (Palmer (1993), 109).

177 See Chapter 4, n. 157.

178 Langdale (2012), 80. See also Metcalf (2009), 421-2, and Karageorghis (1969), 13.

179 Karageorghis (1963), 52.

180 Öztaner (2007).

181 Stewart (2008), 73

182 Metcalf (2009), 270-2.

183 Stewart (2008), 242.

184 Megaw (1958), 50.

185 Dikigoropoulos (1961), 214; Metcalf (2009), 385; Stewart (2008), 73-5.

186 Karageorghis (1960), 250.

187 Balandier (2003).

188 Metcalf (2009), 290ff.

189 On the Theater Kastell, see Zavagno (2009), 125 with further bibliography.

190 Megaw (1988), 143.

191 Ibid., 144.

192 Du Plat Taylor and Megaw (1981), 209-41. Philon was a contemporary of Saint Epiphanios (Sancti Hieronymi Epistolae, LI, 2), who may have consecrated him as bishop of the city. On the walls, see also Dikigoropoulos (1961), 238.

193 Du Plat Taylor and Megaw (1981), 248.

194 Dikigoropoulos (1961), 235; Metcalf (2009), 224-5; also Papageorghiou (2011), 324-5.

195 Ibid., 224-5.

196 See Balandier (2002a), 200-2, and Balandier (2002b).

197 Stewart (2008), 73.

198 Aupert et al. (2003-2004) 858.

199 Megaw (1985a), 205. For Amastris, see Zavagno (2009), 138-49 with further bibliography.

200 Foss and Winfield (1986), 133-5; also Zanini (1994), 201-4.

201 Öztaner (2010).

202 Petre (2012), 231; also Balandier (2002a), 203, and Megaw (1964), 1.

203 Ivison (2007); Zavagno (2009), 143 with further bibliography. 


\section{Urban versus rural}

204 Caraher and Papalexandrou (2012).

205 Stewart (2010), 182; also Papageorghiou (2011), 331-40

206 Ibid., 164. Two other churches - Agios Georgios, dated to the twelfth century, and Prophitis Elias, whose ruins are now buried - can also be found at OuraniaAphendrika, indicating that the city was a main religious centre in the Middle Ages. See also Megaw (1950a), 50-2; Papageorghiou (2011), 338-40.

207 Zavagno (2009), 42-89. Zanini (2013a), 186-8; Baldini et al. (2012), 262-72.

208 Zanini (2013a), 186; also Zanini (2009a), 121-2.

209 Baldini et al. (2012), 248-65;

210 Ibid., 290-1.

211 Zanini (2006) and infra n. 219.

212 For Saint Epiphanios, see Chapter 3 n. 181; for the Campanopetra, see Chapter 4, n. 254. One solidus of Constantine V and two solidi of Constantine VII and Basil II were found in the area.

213 Metcalf (2004), 34-5; 79-91.

214 Ibid., 271.

215 Dikigoropoulos (1965-1966), 262.

216 Dikigoropoulos (1961), 210.

217 Argoud, Callot, and Helly (1980), 53-4.

218 Ibid.; Metcalf (2013a), 70.

219 Zavagno (2011-2012), 142.

220 For the Byzantine Houses complex in Gortyn, see Zavagno (2009), 79-85, and Zanini, (2013), 180; for Syrian and Palestinian cities, see Walmsley (2007), 117 and Walmsley (2012), with further bibliography.

221 "The northern and western colonnades of the Atrium were rebuilt in the second half of the seventh century (as coins of Heraclius [post 631] were found embedded into the wall of the intercolumnia. There is also evidence of newly installed columns on the internal part of the very portico which should be contemporary to the cleaning and enlargement of the presbyterion and the transformation of catechoumena into a cave for building material during Constantine IV's reign" (Christou (1997), 479). Moreover, "new excavations focusing on the annexes to the north of the basilica and four rooms along the northern portico of the atrium. In three rooms the excavators found confirmation of the refurbishment and usage dated to the end of the seventh century. The coins found in the layer of destruction confirmed the range expounded in the previous year (670 to the end of the seventh century). In this period the main nave was also cleared of the debris now piled in the catechoumena" (Hadjisavvas (1998), 672).

222 Megaw, "Reflections," 139-46; Karageorghis and Maier (1984), 303. The excavations at Limeniotissa have never been fully published: see Stewart (2008), 50-1.

223 Christides (2006), 56-60; Papacostas (1999), 212.

224 Metcalf (2009), 458-9.

225 Metcalf (2013a), 70.

226 Ibid., 74.

227 Papageorghiou (2011), 369-71.

228 Cau Ontiveros and Mas Florit (2013), 38.

229 Papacostas (2012); Veikou (2015b)

230 Cosentino (2013a), 73.

231 Veikou (2015b), 367.

232 Cosentino (2013b), 102-3.

233 Cosentino (2013a), 74.

234 Zanini (2009a), 119.

235 Wickham (2005), 653.

236 Walmsley (2012), 322-3.

237 Metcalf (2009), 269. 


\section{An insular economy in transition}

\section{The economy of early medieval Cyprus}

In this chapter I would like to address the changes in the scale of the Cypriot economy in the transition from Late Antiquity to the early Middle Ages. ${ }^{1}$ To do so I will try to assess the level of the local productive organization and infrastructure, the breadth of the distributive networks (both commercial and non-commercial), the patterns of consumption at elite and non-elite levels, and the place of Cyprus within the exchange routes bypassing the political, religious, and cultural frontier between the Caliphate and Byzantine Empire. However, I would like to make two preliminary remarks. I am perfectly aware that this chapter is a sort of natural completion to the previous sections of this book. This is because, directly or indirectly, the sources I have presented the reader with and the kind of analysis I have proposed so far concern the economic dimensions of life in Cyprus from the early seventh to the early ninth century: the forces that shaped local demand (mainly the religious and secular ecclesiastical elites) or production (mainly the building and artisanal activities), urban and rural life, and the fiscal system as supported by the Constantinopolitan administration. Therefore, there is the risk that the reader will find some parts of this chapter repetitive or even redundant. In my opinion, this is not the case, because to assess the scale of economic activity I will engage with the most reliable guide of the economic system: ceramics, evidence I have only skimmed in the previous sections of the book, though I included a long methodological assessment in Chapter $3 .^{2}$

The analysis of ceramics will complement the aforementioned economic vitality of urban and rural structures, as they partially reorganized around artisanal and commercial functions, the role of the central administrative and fiscal system, as shown by the analysis of lead seals, the persistence of urbanoriented elites, as glimpsed in archaeological, architectural, and artistic evidence, the social and political weight of the local archbishopric and of ecclesiastical hierarchies, and, eventually, the importance of the island in pilgrimage routes, as shown in pilgrims' travel logs. In other words, mainly by reassessing and examining previously overlooked seventh- to ninth-century ceramics, it is my intention to demonstrate the persistence of trade market exchange 
relationships on a local, regional, and interregional scale as parallel to the role of the states and the Cypriot socio-political elites in underpinning productive capacity and urban and rural activities.

As Laiou and Morrisson stress, "the Byzantine state ... functioned as a force of economic integration [by providing] the framework for the functioning of the economy as a whole". ${ }^{3}$ In this light, we can trace two modes of exchange at work in the Byzantine Empire: non-commercial and commercial. In other words, insomuch as the elite demand and fiscal system could be regarded respectively as the basic foundation of the regional and local economic sophistication and interregional exchange networks, we must admit that only part of the latter retained a commercial aspect. ${ }^{4}$ As Wickham has stated with regard to the eastern Mediterranean, the vitality of the exchange networks lasted well into the seventh century with a multiplicity of routes that continued to characterize the area even after the conquest of Egypt by the Arabs and the subsequent interruption of the annona from Alexandria to Constantinople. ${ }^{5}$ Moreover, as repeatedly pointed out in the previous chapters, the resilience of Byzantine insular economies and in particular the strategic relevance of islands like Crete and Cyprus across new regional and subregional networks of shipping along eastern Mediterranean shipping routes seem to point to a third economic actor alongside the Byzantine Aegean and the Anatolian plateau. This is not to deny the simplification of the Mediterranean exchange system and a localization of production and regionalization of trafficking, but rather to dispel the idea of a total collapse of the distributive-productive networks.

Ceramics have been effectively used to argue convincingly that Cyprus was at the heart of the Late Antique system of economic exchange, as the literary sources of the period repeatedly praise the local abundance of wheat, wine, and oil. ${ }^{6}$ In his Res Gestae Ammianus Marcellinus, as already hinted at in Chapters 2 and 4, celebrated "this Cyprus so fertile and rich in produce of every kind that without the need of any external assistance, by its nature alone it builds cargo ships from the keel to the topmast sail". ${ }^{7}$ As Papacostas effectively summarized in his contribution focused on the fifth- to early seventh-century Cypriot economy, the quite effective role of the island in fiscal and commercial exchange can easily be surmised by two types of ceramic products: amphorae, in particular Late Roman 1 type amphorae (LRA1), and fine wares of the Cypriot red slip type (CRS), the most common tableware found across the island. ${ }^{8}$ I have already referred to the role of Cyprus in the annona routes leading from the Nile River Valley to the capital as documented by hubs excavated on the southern coast (such as Agios Georgios). This evidence can be complemented with the LRA1 and CRS finds yielded by excavations in Alexandria and the Delta region, the vast majority of which seem to have been produced in Cyprus. ${ }^{9}$ As will be seen, the Egyptian link did not simply come to an end, as one might expect, but rather remained vital and economically solid well into the eighth century, when Cyprus could still boast many types of pottery (amphorae, fine and coarse wares) both exported to and imported from Egypt. 
As Cyprus took advantage of its proximity to Egypt, it becomes clear that the fecundity of the island and its strategic position also prompted sound economic ties with other areas of the eastern Mediterranean that historiography has too often regarded as impermeable or even hostile, like Syria and Palestine. The interaction between the neighbouring Umayyad regions and Cyprus is revealed by the careful re-examination and attentive reassessment of the ceramics found in pre-1974 investigations (in particular at SalamisConstantia) and in the more recent excavations at Kourion, Paphos, and Amathos, as well as in the above-mentioned rural surveys. This reassessment shows that the movement of goods and contacts with Islamic centres of production persisted and mirrored the smooth transition experienced by material culture, economic activities, and social structures in the Levant. Indeed, the methodologically primary role given to pottery should not lead us to forget about other object categories that I have already mentioned and will analyse in the course of the present chapter (from coins to seals, from glass to metal works).

However, it is clear that ceramic evidence allows us to examine not only patterns of interregional exchange activity but also the local and regional distributive patterns reflected in the character and level of domestic and household production. In particular, the non-localized distributive network Dark has discovered for sixth- and seventh-century Cypriot coarse cooking wares echoes the (previously unsuspected) widespread diffusion of the so-called Dhiorios cooking pots found as far away as Dalmatia and Syria in the late seventh and eighth centuries. ${ }^{10}$ It could be, therefore, that this evidence, paired with the resilience of at least some classes of CRS continuously produced and exported from Cyprus, helps to further check the apparently univocal results of the above-mentioned series of rural surveys. ${ }^{11}$ As we have seen, these surveys often tempt us into imagining the abandonment of rural sites and the reduction of urban activities prompted by the general political instability of the period.

As the reassessment of Cypriot pottery is only in its infancy, one can propose a loose comparison with Syria and Palestine for which continuity of seventhand eighth-century trade reflected the continuity of amphora manufacturing, the resilience of a strong regional ceramic tradition (as pointed out by the so-called Palestinian Table Fine Wares and the Jerash Bowl), as paired with the architectural flourishing of rural areas (like the steppe of modern Jordan), and urban structural change marked by major economic and organizational resilience. ${ }^{12}$ For instance, in Cyprus, locally made pottery provisionally dated to the late seventh to early eighth century and evidence of building activities in the same period have been found in the Kalavasos-Kopetra and MitseroPolitiko areas. ${ }^{13}$ The contributions of Armstrong, Vroom, and Randall have shed further and comparative light on the productive and distributive networks of LRA1, fine wares, and handmade and slow-wheel pottery. ${ }^{14}$ For instance, as production of LRA1 continued in Cyprus at least until the beginning of the eighth century, so-called LR13 globular amphorae were also manufactured 
on the island, as showed by later variants yielded at Saranda Kolones and Kourion; they seem to have travelled as far as Egypt and the Levant. ${ }^{15}$ Leaving the containers aside, Armstrong has convincingly showed that CRS continued to be produced well into the late eighth and early ninth century, for in Lymira they have been found in sealed deposits together with ninth-century Islamic glazed pottery. ${ }^{16}$ Finally, our knowledge of handmade and slow-wheel ceramics has drastically improved in the past few years because of good comparative studies. For instance, Randall uses "additional evidence from Sagalassos, [where] a series of wheel-made cooking pots and some Cypriot types were found [to show] their similarities in form, techniques, and fabric with exemplars from Cyprus or Palestine". ${ }^{17}$

With this in mind, one can turn to the area around the above-mentioned barrel-vaulted churches of Ourania-Aphendrika or the Kaleburnu-Galiborni Plain (Agia Varvara and Panagia Aphendrika in Sikhada), where large amounts of scattered ceramics and building materials are clearly visible in the nearby fields and could bear some resemblance with the settlement pattern documented for the island of Naxos and the Balearics. ${ }^{18}$ For Naxos, as we have already mentioned, Vionis has shown the existence of ecclesiastical buildings (rural chapels) dated to the eighth and ninth centuries on the basis of diagnostic pottery fragments and fresco decoration. ${ }^{19}$ These small churches have been associated with small and large rural settlements, which can be found not only in the interior but also on the coast, a picture opposing traditional theories about the abandonment of coastal regions and the withdrawal of local populations to mountains or island interiors. ${ }^{20}$ In a similar vein, the

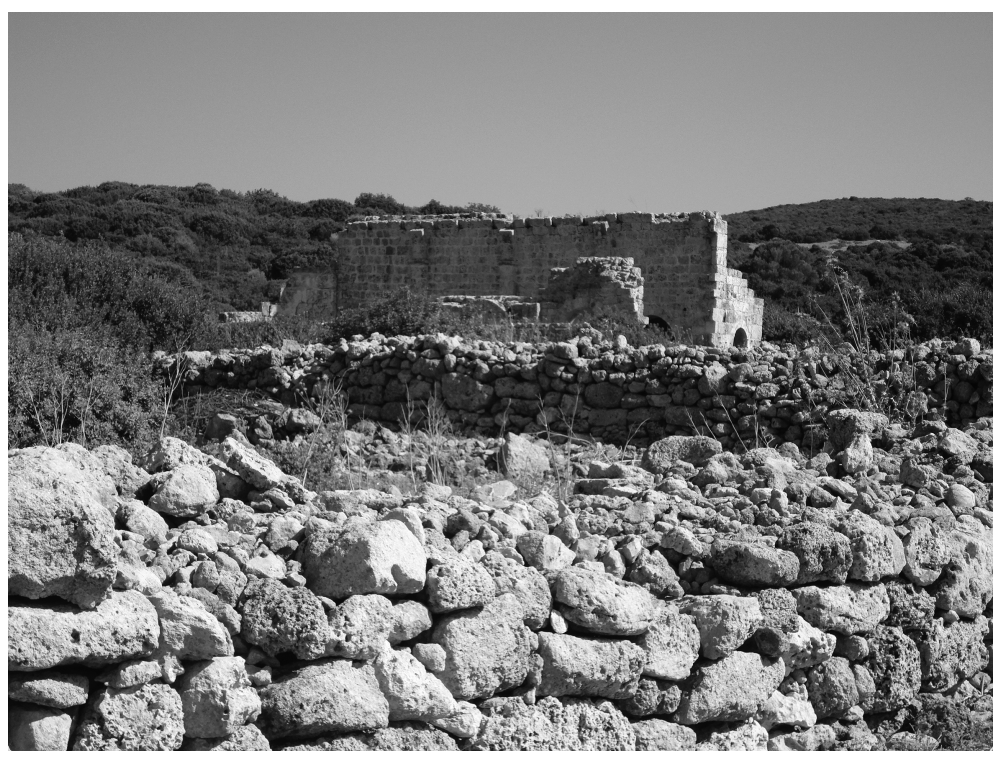

Figure 6.1 Eighth century Church of Aphendrika (Ourania-Aphendrika, Karpas Peninsula) 
above-mentioned reassessment of ecclesiastical buildings and associated pottery assemblages in the Balearics revealed that during the Byzantine period basilicas were rebuilt or refurbished across the countryside and along the coast. ${ }^{21}$ Things being so, a similar important role of churches could be hypothesized for the landscape of the plain of Kaleburnu-Galiborni (as well as in other small rural pockets of fertile Cypriot lands), where Agia Varvara clearly dominates the whole eastern coastline from Cape Andreas to Cape Greco, and Panagia Aphendrika in Sikhada, which is more secluded and possibly linked with some contemporary hillside settlements.

Finally, one should not forget about the fiscal and administrative level of analysis hinted at by the literary and documentary sources and the numismatic and sigillographic evidence. As Wickham states, with "the sharp localization of so much of the productive structures of the empire ... the survival of medium distance exchange was ultimately the work of the state". ${ }^{22}$ In Cyprus, in fact, Constantinople played a crucial role in shaping and directing the level of local demand and production, although not to such a great extent as in the Aegean or in Anatolia. As repeatedly referred to in previous chapters, the economic capacity of the church and the administrative, fiscal, and military structures of the state prompted levels of central control on the collection and distribution of resources. Leaving aside the social and economic interests of the local aristocrats, who often acted as members of the imperial administration, seals, coins, and archaeology - as paired with literary and documentary evidence - show the influence of the Byzantine state on the economy was greater from the beginning of the eighth to the tenth century, for the state has virtually no competitors. ${ }^{23}$ Although the latter assertion could be partially revised especially in light of recent archaeological discoveries at the islands of the periphery of the Empire, it was nevertheless true that the state was more important than the marketplace as an economic force, as the pattern of supply and demand was heavily slanted towards Constantinople. ${ }^{24}$ The analysis $^{2}$ of locally made and imported pottery, in particular CRS wares and Glazed White wares (GWW), will confirm the enduring pull of Constantinople in shaping the surviving interregional exchange networks.

But the capital was in all evidence not the only focus of what amounted to a complex network of long- and medium-distance exchange networks partially centred on Cyprus. Indeed, at least in the Umayyad period, the role of Damascus in influencing the movement of goods and the circuits of exchange impinged upon Cyprus. Arab literary sources, although written from the ninth to the twelfth century, are riddled with references to trade and commercial exchange between Cyprus and the Muslim Levant. ${ }^{25}$ Ibn Hawqal, writing in the tenth century, mentioned that on the island one could find "mastic of good quality and abundant gum [as well as] silk, flax, wheat barley, cereals, and so much abundance that cannot be described". ${ }^{26}$ A contemporary Arab geographer, al-Muqaddasī, stated that Cyprus offered many advantages to Muslims engaged in trade, pointing to the large amount of merchandise, goods produced, and its proximity to the Syrian coast (only one night and 
day of navigation). ${ }^{27}$ Moreover, al-Mas'ūdī, also writing in the tenth century, reported the adventurous travels of an Arab former prisoner from Syria to Constantinople via Cyprus disguised as a merchant. ${ }^{28}$ The story is fictional but nevertheless reveals that direct trade relations between the Byzantines and the Umayyads were regarded as feasible, while at the same time supporting the idea of a continuation of commercial practices between Cyprus and the Muslim lands that continued almost unabated from the early Islamic well into to the Abbasid era.

As will be seen in the next section of the current chapter, the evidence provided by a more up-to-date analysis of pottery yielded by pre-1974 (in the northern part of the island) and recent archaeological digs (in the Republic of Cyprus) can be set against the ceramics and other types of material evidence, like glassware yielded in nearby regions such as Isauria, Pisidia, Lycia, and Cilicia, as well as Syria and Palestine. This will hopefully allow us to show a polycentric pattern of local production and exported goods continuing well into the eighth century, placing Cyprus at the heart of a series of long-, medium-, and short-range interlocking economies. I believe these coalesced to allow the more fractured eastern Mediterranean system of exchange to subsume major trade routes and (Byzantine) state-oriented movement of goods, as well as overcoming the political divide between Byzantium and Islam, as Cyprus retained sound commercial relations with the nearby regions of the Muslim Levant.

\section{In a league of their own: ceramics in early medieval Cyprus}

When it comes to Cypriot medieval archaeology, too often ceramics have been overlooked or regarded only as a complement to other, more important types of evidence. In other words, they make an appearance only when the favoured types of evidence (literary sources, seals, coins, buildings, and archaeology) have been exhausted. Therefore, ceramics have often been used simply to confirm in chronological and analytical terms conclusions already drawn thanks to more solid and "important" kinds of evidence. The usual conclusion being that the Cypriot economy was in disarray as a result of the Arab invasion and the collapse of the fiscally oriented exchange system in the eastern Mediterranean. Examples of this attitude can be found in the volume by Metcalf, where pride of place is given to sigillography and numismatics, but the analysis of ceramics is limited to less than twenty pages (with only one page dedicated to eighth-century pottery). ${ }^{29}$ The same applies to other important summaries of the period under consideration here, such as those of Dikigoropoulos, Vryonis, and Kyrris, though a partial exception is provided by Papacostas. ${ }^{30}$ Naturally, partial or full reports of archaeological surveys provide us with more detailed and extensive analyses of ceramic finds. One cannot include here Rautman's seminal work on the Kalavasos-Kopetra village or Megaw's long-awaited publication on the basilica of Kourion without mentioning the well-published ceramics from the excavations at Paphos or Salamis-Constantia as well the contributions of Randall and Armstrong. ${ }^{31}$ 
However, as I have remarked already, even these contributions do not breathe easily in the more rarefied atmosphere of the second half of the seventh or eighth century. ${ }^{32}$ Indeed, one should discount the above-mentioned difficulties in identifying and cataloguing pottery dated to the late seventh to the ninth century, although - as Armstrong has correctly argued - the very fact that eighth-century pottery was extensively manufactured and traded in provinces has been overlooked. Therefore, I will try here to address this gap by extensively using ceramic as an important indicator of a resilient and partially monetarized early medieval Cypriot economy in tune with rather than simply as an accessory to other types of evidence. This should allow me to put Cyprus in the same league as other Mediterranean islands, whose economies were more prosperous than has been previously thought. ${ }^{33}$

First, as already hinted at, one should consider the different typologies of pottery (amphorae, fine table wares, handmade/slow-wheel pottery, or coarse cooking wares), because their movements provide us with a wide range of information. Indeed, as Brubaker and Haldon mention: "that the routes taken by amphorae and fine wares are different is partially explicable through the different interests of exports for profit and state-backed transportation ... and partially through the resistance to [or unprofitability of] imports". ${ }^{34}$ Amphorae were receptacles for such commodities as wine, olive oil, and, less often, wheat, as they were used for long-distance transportation of bulk goods mainly by sea. ${ }^{35}$ The early Byzantine-style amphorae (but not of course specific classes) remained in use well into the seventh and eighth centuries, when in Cyprus we witnessed both local production and considerable importation of goods. ${ }^{36}$ This should come as no surprise, as Strabo had previously praised the fertility of the island as rich in wine and oil. ${ }^{37}$ Ammianus Marcellinus in the fourth century and Hierokles in the fifth century followed in the footsteps of the illustrious Roman geographer, whereas in both the second half of the sixth century and the early seventh century Venantius Fortunatus and Pope Gregory the Great celebrated Cypriot wines imported to Gaul and Rome. ${ }^{38}$ In particular, the latter went out of his way to exalt the fertility of the island and mistranslated a passage of the biblical Song of Songs: "Cyprus insula est in quia uberiores vineam quam alibi nascintur". ${ }^{39}$

Though the literary witnesses to the fertility of the islands dwindled in the following century we can nevertheless rely on amphorae to draw a picture of the resilience of the local economy. On the one hand, we are now in a position to extend the life span of LRA1 containers well into the eighth century thanks to new evidence from Crete and Chios. ${ }^{40}$ Indeed, this type of container was originally produced in Cilicia and Cyprus as well as on the Levantine coast from the sixth to the late seventh century. ${ }^{41}$ In particular, kilns that produced these amphorae have been found near Nea Paphos, Amathos, Kourion, and Akamas. ${ }^{42}$ In fact, Cypriot manufacture was different in fabric from any other production, for as Papacostas argues: "a development in production method and typology has been documented: the usual forms were worn out by the Arab invasions and the usual types not found anymore". ${ }^{43}$ 
Joanita Vroom has convincingly argued that Cyprus exported LRA1 to Lymira until the late seventh century. ${ }^{44}$ From the same period onward we can also trace the appearance on the island of local copies of LRA1, which were later replaced by the so-called globular jugs (also known as post-LRA 2 amphorae or LR13). With regard to the latter, we should mention that in Kalavasos-Kopetra a local variant has been documented (Kamp 1) as also produced in Cilicia (at Seleucia) and that LR13 have also been found in eighth-century layers at Kourion with a manufacture centre at Amathos. ${ }^{45}$

Indeed, studies comparing deposits from the Sinai desert with those yielded by the excavations at the theatre in Paphos have revealed that both LRA1 (also unearthed at Kourion) and globular amphorae (made in Cyprus, according to the petrographic analysis) dated to the late seventh century were found in Ostrakine (North Sinai). ${ }^{46}$ The existence of an Egyptian link is further evinced by the so-called Late Roman 7 (LRA7) Egyptian amphorae unearthed in the eighth-century layers at Paphos. ${ }^{47}$ LRA7 has often been regarded as a simple regional transport vessel, although in truth it was a common wine container across the early medieval Mediterranean. ${ }^{48}$ It is also interesting that an eighth-century globular amphora found in Paphos has revealed morphological similarities with specimens yielded in Sarachane (Constantinople) and Naples (Santa Patrizia), pointing to resilient shipping links between the city and other coastal regions of the Byzantine Empire. ${ }^{49}$

In this light, we should remember that LRA7 were also common in the pottery assemblies excavated at Lymira (dated from the late seventh to early ninth century); therefore, it is possible to assert that the continuous strength of Egyptian economy influenced the persistence of interregional commercial trade across the eastern Mediterranean. Indeed, contrary to what Wickham has asserted, Mediterranean links seems to have been less marginal to the Egyptian economy from the late seventh century on. ${ }^{50}$ Cyprus (and Cilicia) clearly imported Egyptian goods as pointed out by bag-shaped Late Roman 5 amphorae (LRA5) dated to the late seventh and early eighth centuries documented at Paphos-Saranda Kolones: their fabric enables us to identify their origins in the Nile Delta and Middle Nile Valley. ${ }^{51}$ This typology of containers has also been unearthed in late seventh-century layers at Kourion and Kalavasos-Kopetra. ${ }^{52}$ For context, fragments of bag-shaped amphorae have been documented by Vroom in Lymira. They boast incised decoration and soft-to-medium coarse fabric and bear a striking resemblance to LR5/6 found in Jerusalem and in Gortyn (in seventh- to eighth-century contexts). ${ }^{53}$

Evidence from Cyprus and Lymira tallies with the archaeological results of the nearby Muslim Levant, for which Walmsley has showed that "pottery reveals that trade in commodities between Egypt, especially the Delta, and southern Syria-Palestine took place on a significant scale [for the whole] seventh century" ${ }^{54}$ With this in mind, one could also consider the diffusion of Egyptian red slip ware (type A from Aswan) documented at many Syrian sites, like Pella, Scythopolis, and Tiberias, the export of which to Cyprus is shown to have endured the eighth century at many urban sites (Salamis-Constantia, 
Limassol, and Kourion). ${ }^{55}$ Moreover, mid- to late seventh-century Caesarea type 1 amphorae from Egypt have been unearthed at Kourion and led Hayes to conclude that "what all these seem to point is an ... export phase in the early Umayyad period in which the Egyptian ware took over the market formerly held by African ware and competed with the last products of Cypriot workshops". ${ }^{56}$ It is important to note that late seventh-century Cypriot pottery has been found in large quantities along the Egyptian northern coast, central Delta, and northern Sinai. ${ }^{57}$ In particular, Cypriot imports have been shown to be equally common at Abu Mena, from which a large number of pilgrim flasks found their way to Cyprus from the eighth to the tenth century. ${ }^{58}$

The evidence I have presented so far should enable us to sketch a commercial network involving Cyprus and the coterminous regions under Umayyad rule, particularly Egypt and Syria-Palestine. With regard to the latter region, we can stress that LRA5 of Palestinian manufacture have been recovered from late seventh- and early eighth-century layers at Paphos, Salamis-Constantia, and Amathos, as they match the so-called Caesarea type 3 amphorae, which possibly carried wine, found at Kourion and bearing a striking resemblance to examples found at Khirbat al-Mafjar and probably produced around Scythopolis. ${ }^{59}$ Late seventh-century imitations of Syrian amphorae have also been found on Cyprus. ${ }^{60}$

The provenience of these containers may pair with that of fine and coarse wares. For instance, the so-called decorated buff ware vessels manufactured at Khirbat al-Mafjar but also found in Jerusalem, pointing to a continuous occupation of the site until the ninth century, have also been unearthed in excavations at Saranda Kolones and Nea Paphos. ${ }^{61}$ Similarly, casserole and cooking pots imported from Palestine have also been unearthed in Lymira. On the other side of the exchange link, typical eighth-century domestic and cooking wares produced in Cyprus - the thin-walled, wheel-ridged vessels also known as Dhiorios cooking pots - have been found in Umayyad deposits in Beirut and in eighth-century layers in Palestine. ${ }^{62}$ In fact, evidence for production of a peculiar type of cooking pot (so-called "brittle wares") has been found both in Cyprus and Beirut well into the eighth century. ${ }^{63}$ Additionally, a peculiar type of painted ware (broad line) found in southern Italy and Albania has been proved to date to the sixth to seventh century, but was still being made in the ninth and tenth centuries. Vroom has indeed documented that these wares, which boast a uniform decorative style, "show parallels in decoration style with contemporary painted wares from other parts of the Mediterranean including Crete, the Greek mainland, the Balkans, southern coast of Turkey, Cyprus, Syria, Jordan, Palestine, Coptic Egypt, and the Maghreb". ${ }^{64}$

Before turning to the analysis of coarse wares, we should stress that the ceramics we have encountered so far help shed light on a continuous movement of people and goods between Cyprus, the southern coasts of Anatolia, and the Islamic centres of production. This picture of resilient interregional exchange routes across the eastern Mediterranean and the religious and political divide between Byzantines and Umayyads in the late seventh and eighth 
centuries tallies with data derived from other sources that I have repeatedly mentioned previously: the Arab-Byzantine coinage, the travel logs of pilgrims, and the reports of Arab geographers. Indeed, this array of literary and material evidence reverses the prevalent notion of the Islamic and Christian dominions as separate worlds that interacted only through conflict. ${ }^{65}$ Since we can treat the movement of pilgrims and diplomats (such as the phangoumeneis) as proxy data for commercial shipping, the pottery from Lymira and Lycia provides us with a useful complement to broaden the horizons of exchange between Byzantines and Umayyads. ${ }^{66}$ This included, in all likelihood, southern Anatolia and hinged on Cyprus as a convenient and strategic hub, possibly due to the peculiar political status of the island. ${ }^{67}$

Numismatic evidence, in particular the analysis of late seventh- and eighthcentury pre-reform Arab-Byzantine coinage, can help to sharpen the focus of my analysis. In Cyprus one can indeed identify Byzantine emissions (coins issued by Justinian II, Tiberios, and Leontios have been found in Constantia and Kourion) and Arab specimens, both indicating the maintenance of political, commercial, and cultural relations between the two empires through the complex imagery and prototypes of all these coins. ${ }^{68}$ This claim is further enhanced by the Arab-Byzantine coinage already mentioned. ${ }^{69}$ With regard to these specimens, on Cyprus we face the same puzzling dichotomy experienced in Syria-Palestine, where, according to Goodwin and Philips, "there is a gap between many known types and frequencies of pre-reform transitional coins known through the antiquity market and the much lower numbers recovered through archaeological work". ${ }^{70}$

Nevertheless, Arab-Byzantine copper coins dated to the period under scrutiny and issued at Homs, Damascus, and Tiberias have been found in excavations at Paphos-Saranda Kolones (four specimens), Salamis-Constantia (six specimens), and Kourion (one specimen) ${ }^{71}$ To these one should also add some postreform coins (i.e., post 692) that have been documented at the very same Cypriot urban excavations. ${ }^{72}$ It is further worth mentioning a gold dinar dated to $720-21$ and an Abbasid silver dirham, both recovered at Kourion. ${ }^{73}$ Moreover, Metcalf has pointed to the existence of a large but unpublished score of clipped dirhams, the dating of which is still unclear (before or after 800). ${ }^{74}$

This suggests that the less monetized economy of Cyprus, as well as Syria and Palestine, reflected the adoption of different ways of socially manifesting wealth rather than the waning of exchange and trade. I have already stressed the fact that Arab literary sources echo the link between Cyprus and Levantine urban centres like Ba'albek. ${ }^{75}$ Therefore, it should come as no surprise that shipping routes (including the movement of bulk goods from the richer regions of Syria-Palestine) linked Cyprus with the Damascene Jund, which was geographically closer to the island and whose territory included the capital of the Caliphate. ${ }^{76}$ The Islamic lead seals recovered on the island from Paphos, Khlorakas, and Limassol point to regular correspondence between the Caliphal administration and local authorities, although the specimens seem to date after the late seventh century. ${ }^{77}$ Metcalf hints at the possibility that at least 
some of the Islamic seals found on the island could have belonged to visiting merchants (as opposed to those bearing the word Qubrus and possibly issued by local Muslim administrators). ${ }^{78}$ Although this remains a speculation, we possess enough material evidence to indicate commercial and social exchange across eastern Mediterranean political boundaries.

I have already referred to mercantile activities on the island reported by Arab geographers like al-Mas'ūdī or al-Muqaddasī, but I would like to note that the latter also recounted the eighteen ships loaded with silver and gold that sailed from Cyprus to contribute to the decoration of the mosque of Damascus under Caliph al-Walīd. ${ }^{79}$ As Papacostas points out, this passage may be related to the export of glass tesserae for mosaics. ${ }^{80}$ Indeed, as Young stresses, the lack of suitable raw material did not impede the development of a reliable glass industry on the island: "There is evidence of manufacture in Cyprus at least for the early Byzantine period at Agios Philon and Soloi [as] a tradition of glass manufacture in Cyprus is also attested by the occurrence of types of vessels rarely found elsewhere". ${ }^{81}$ Archaeology has argued convincingly that the local glass industry continued until the late seventh century in Kourion and possibly Dhiorios-Mersineri and well into the eighth and ninth centuries at Paphos (Saranda Kolones) ${ }^{82}$ It is interesting that, notwithstanding the stylistic and technical differences between the early Byzantine vessel types and later productions, the character of the glass vessels reveals conspicuous similarities with Syrian-Palestinian manufactures. ${ }^{83}$ It is possible that culets or other raw materials could also have been imported from the same region and used in local factories. One of these factories has indeed been excavated at the castle known as Saranda Kolones (Forty Columns) in Paphos. ${ }^{84}$ Here, as John Rosser has mentioned, the remains of an eighth- to ninth-century glass factory have been unearthed beneath one of the massive towers strengthening the powerful walled circuit erected sometime in the twelfth century. ${ }^{85}$

Another reference hinting at the existence of multiple lines of communication and complex levels of interregional commerce between Cyprus and the Muslim Levant can be found in the Annales of Eutychios of Alexandria written in the first half of the tenth century. In fact, Eutychios mentions the shipment of fifty Cypriot cedar trunks to the patriarch of Jerusalem to help with the refurbishment of the Church of the Holy Sepulchre, which is also documented as owning estates and a metochion on the island. ${ }^{86}$ Ideally we could pair this bit of information with the above-mentioned reference to the Cypriots sailing to and from Gabala in Syria from the Acts of the Seventh Ecumenical Council. Regular trade contacts between the Levant and Cyprus can be once again tested against the ceramic record. The so-called bench deposit at SalamisConstantia dated to the middle of the eighth century has revealed Islamic lamps of Palestinian provenience together with Hayes type 9 forms of CRS. ${ }^{87}$

Some sherds of "Arab ceramics" with clear typological similarities to Levantine samples dated from the seventh to the eighth century have been also discovered at Amathos with distinctive Umayyad decorative motifs. ${ }^{88}$ Finally, as repeatedly referred to, we should include the amphorae with kufic 
inscriptions dated to the late seventh or early eighth century found at Paphos, where, as previously hinted at, excavations at the basilica Limeniotissa have also revealed a number of unpretentious residential buildings erected with spolia. ${ }^{89}$ The floor of a rather showy rectangular hall paved with polychrome marbles from the nave of the church bears Arabic inscriptions. These inscriptions all include funerary epitaphs and reflect three different stages of the Arab presence, extending from the late seventh to the late eighth century, that is, after the retreat of the host of Arab soldiers al-Balādhurī reported as settled on the island in the aftermath of the first raids. ${ }^{90}$ It is worth mentioning here that according to Papacostas one of the inscriptions may have referred to a merchant and been dated to $780 .^{91}$

I have so far presented typologically varied evidence hinting at regional and long-distance commercial exchange using Cyprus as a convenient stepping stone along the trade routes linking the Egyptian, Levantine, and southern Anatolian coasts. Indeed, some of the traded goods seem to have spread even beyond the eastern Mediterranean boundaries, reaching North Africa. Eighthcentury cooking pots of a grey-black type with a long neck and two large handles have been documented as imported to Salamis-Constantia from Carthage, as the aforementioned seventh- to eighth-century amphorae with kufic inscriptions found at Paphos may have been manufactured at Djerba. ${ }^{92}$ We should, however, set this array of data against that pointing to substantial commerce within the political boundaries of the Empire. Here, the GWW pottery manufactured in Constantinople and found at many excavated sites across the island represents a convenient yardstick. ${ }^{93}$ As Wickham argues:

GWW replaced Phocean RS [red slip] as the dominant fine ware [and though with] a much more restricted distribution ... was found on several of the southern islands, notably Crete and Cyprus, showing continued exchange links with the capital some $800 \mathrm{~km}$ away (nearly twice as far in the case of Cyprus). ${ }^{94}$

GWW wares from Constantinople have indeed been documented in Soloi, although not in large quantities and dated to a ninth-century partial reoccupation of the basilica, as well as in Paphos-Saranda Kolones (dated to the eighth century) and Kourion (dated to the late seventh/early eighth century). ${ }^{95}$

One should also weigh Constantinople's centrality in local Cypriot economy against the persistence of military and civil officials as well as the resilience of the fiscal administration. To do this we should analyse the production, distribution, and consumption levels of the CRS, by far the most common fine ware in circulation on the island from the fifth to the late seventh century and even beyond. ${ }^{96}$ Here I deliberately leave aside the recent debate concerning the most appropriate terminology to identify this class of ceramics and their possibly exclusive Pisidian origins. ${ }^{97}$ Rather, I will focus on the fact that centres of CRS production have been identified in Paphos, and other workshops are suspected in southern or western Anatolia. Indeed, we should treat evidence 
with care, for finds from the Anatolian production sites include many variations in quality and finish that cast doubt on the distinction between real and derivative CRS. ${ }^{98}$

Nevertheless, CRS distribution shows an extensive trade network centred on Cyprus and stretching to the Asia Minor coastline, the Aegean, and the Levant. ${ }^{99}$ For instance, CRS is documented as having been imported from Cyprus well into the late seventh and eighth century in Pedlenissos (Pisidia) and Lymira, as well as in other Cilician sites and as far as Gortyn in Crete. ${ }^{100}$ At most of these sites local imitations of this peculiar class of fine wares are also documented, including forms excavated across the eastern Mediterranean at Anemurium, Perge, Dhiorios, Kalavasos-Kopetra, and old Cairo. ${ }^{101}$ Armstrong has elaborated, saying:

Cypriot red slip Wares have been found at Anemurium where eighthcentury 'Form 9' have been yielded together with a new form (so-called 'Well-Form') also found in Limyra (as securely dated to the eighth century). The latter could be possibly associated with the so-called Hayes Form 6 found at the excavations at Paphos-Saranda Kolones (originally dated to the late sixth-early seventh century). ${ }^{102}$

New archaeological evidence from Lycia (Lymira, Balboura Survey, and Xanthos) has confirmed the continuity of CRS manufacture until the mid to late ninth century. At Lymira sherds of Hayes type 9 have been found in association with some ninth-century Islamic glazed pottery, whereas at Balboura a later chronology for CRS allowed the excavators to document levels showing the economic and demographic continuity of rural settlements. ${ }^{103}$ In Xanthos, Emanuele Pellegrino and Armstrong have demonstrated that "there was much interaction [between Lycia and] Cyprus in the seventh and eighth centuries, [judging by] the very large quantities of Cypriot red slip ware of the final type found there". ${ }^{104}$ The trade circuit stemming from the examination of the CRS distributive pattern partly overlaps with that of amphorae, as this type of fine ware has been documented in association with ninth-century specimens of LRA1 unearthed at Emporion (Chios); moreover, the interregional trade network associated with Cypriot red slip Ware extended to the Nile and Caesarea and along the North African coast via Crete (Pseira) to Carthage, although it did not reach mainland Greece and Constantinople. ${ }^{105}$

The aforementioned restraint to CRS export should be regarded as a reminder of the localization of production and regionalization of exchange that characterized much of the economy of the Byzantine Empire from the late seventh to the early eighth century and which also affected Cyprus. Although the island retained an important role in regional and interregional exchange, the picture emerging from the analysis of locally made coarse or cooking wares seems to point to a decisive fragmentation and impoverishment of regional industries. In truth, a more attentive analysis of local manufactures compared with evidence unearthed in Syria-Palestine, Cilicia, and 
even Sicily attests to a resilience of the demand for professional potters and a less pronounced decline of urban markets. ${ }^{106}$ I must admit that I agree in principle with Rautman when he states that more often than not, handmade pottery is understood as a sign of shifting economic concerns and narrowing patterns of exchange, although its practical and economic utility ensured that its production would persist in rural households. ${ }^{107}$ Though it seems likely that the volume of shipping and the amount of local production were declining, handand wheel-formed pottery, ranging from plain tableware to cooking ware and storage vessels, continued to be manufactured on Cyprus well into the eighth century. $^{108}$

Indeed, one should notice that the so-called plain vessels with hollow bases and plain lids, the dimple-bottom jugs from Kornos Cave, as well as the coarse fabric cooking wares in various shapes with thick walls found in late seventh-century layers at Kalavasos-Kopetra and in the early eighth-century deposits at Kourion reveal a confident use of technology, traditional manufacturing techniques, and skilled workmanship. With regard to the latter, it is worth mentioning that locally made wares in Cyprus show no fundamental cultural break after the supposed catastrophe of the Arab raids. Instead, we are confronted with a rather smooth shift in the scale of pottery production, which reminds us of the developments in the ceramic repertoire of SyriaPalestine. ${ }^{109}$ There, as I mentioned in Chapter 1, only a modest development of pottery is discernible during the seventh century, followed by a period of accelerated change in the late seventh and the beginning of the eighth century. This change was neither systemic nor culturally radical. ${ }^{110}$ In the same way, late seventh- to early eighth-century local Cypriot wares showed no revolutionary differences in typology or technology from their late sixth- or early seventh-century predecessors. ${ }^{111}$ In other words, the Arab raids did not precipitate any abrupt change in manufacture and technical skills. These were mostly of a traditional type; only in the eighth century at the earliest did they show further development with the introduction of a technology imported from the Levant - the so-called Islamic kiln, which was reusable. ${ }^{112}$ As Vroom has recently shown, it seems that in Cyprus the use of the wheel was abandoned sometime between the eighth and tenth century. ${ }^{113}$

One should consider here the distributive pattern of Cypriot coarse and cooking wares as not fully localized and spreading across the neighbouring regions. ${ }^{114}$ This is shown for instance by the wheel-ridged and thin-walled cooking wares in a red fabric found at Lymira but first recognized at the kiln site of Dhiorios in Cyprus (not far away from Kornos Cave) and dated to the mid-seventh to early eighth century. ${ }^{115}$ Indeed, one should consider that, as Armstrong has effectively documented:

Dhiorios kiln products have been found in Palestinian deposits and dated to the eighth century, and as far as the Adriatic (in a shipwreck off the coast of Narezine in Dalmatia) ... Dhiorios cooking pots have been found at Anemurion in an eighth-century well deposit together with a 
similar hand-knobbed jug; some have been published from an Umayyad deposit in Beirut. ${ }^{116}$

As we have seen, the small pottery factory in the area of Dhiorios-Mersineri on the western part of the Kyrenia range was excavated in 1950s and later published by Catling, who concluded that the peak of prosperity seems to have been in the seventh and eighth centuries, when fourteen local kilns were engaged in the manufacture of wheel-made vessels with decoration limited to horizontal wheel ridging (so-called Dhiorios cooking wares) ${ }^{117}$ Once again here we can see similarities with the "more visible" developments of material culture in Syria and Palestine, where, as Walmsley points out, "the growing dependence on locally produced pottery ... encouraged the growth of townbased ceramic industries [because] by the start of the eighth century locally manufactured wares were dominant in the region". ${ }^{118}$ As already hinted at, excavations at the site of Panagia have revealed a local production of Hayes type 9 CRS and continuous use of the site until the late eighth century (as also demonstrated by the above-mentioned miliaresia of Artavasdos and Nikephoros). ${ }^{119}$ Indeed, Dhiorios seems not to have been the only area of production for local wares, as a group of eighth-century cooking pots has been documented in Paphos as not related to Dhiorios samples. ${ }^{120}$

Indeed, evidence unearthed at different Cypriot sites points to a variety of ceramic productions dated to the late seventh to eighth century, including fine table wares, cooking wares, and storage vessels. ${ }^{121}$ It would be interesting to identify clear patterns of spatial distribution for the different typologies of locally produced ceramics, as Walmsley has proposed for Syria. There the analysis has dwelled upon three case studies: Jerash Bowls, Palestinian Fine Wares, and Red Painted Wares, pointing to a relatively wider dispersal of these classes because of a convenient production-to-distribution cost and increased demand due to their quality and aesthetic appeal. ${ }^{122}$

By the same token, for Sicily, Wickham and, in more detail, Molinari have sketched a picture of an island roughly divided into western and eastern halves based upon ceramic links: "Pots recovered ... on naval shipwrecks in the northern and western parts of the island have shown that they were possibly produced in Campania. Conversely ceramic bodies of amphorae recently recovered in assemblages along the east coast of the island show eastern Mediterranean features". ${ }^{123}$ This reflects the fact that eastern Sicily was more linked to the Aegean and Constantinople via the "ancient trunk route" identified by McCormick, whereas western Sicily was part of the Tyrrhenian system of exchange gravitating towards Rome and Naples, evidenced for instance by the Sicilian oval lamps recovered in those cities. ${ }^{124}$ This curiously contrasts with the analysis of amphorae as indicators of economic activity on the nearby island of Malta. As Bruno and Cutajar have recently shown, Malta moved along "emporion" lines in a similar way to that documented in the northern half of the Adriatic rim (for instance on Comacchio and in the Venetian lagoon). ${ }^{125}$ Indeed, "in both areas amphorae and specifically amphorae of 
eastern Aegean origin, are considerably more numerous than the [exemplars] from neighboring regions". ${ }^{126}$ In Malta we can also document an analogous source of importation of coarse wares as late as the tenth century, enabling us to conclude that the Maltese archipelago acted as a commercial bridge across the political divide between the Arabs and the Byzantines, above all connecting the central and the eastern halves of the Mediterranean basin. ${ }^{127}$

Moreover, in Sicily as in Syria-Palestine (in Malta we do not possess detailed analysis of local coinage), numismatic evidence plays a big role in reconstructing the differences between districts within the regional areas as well as identifying structures and places where local and distantly sourced commodities may be found. ${ }^{128}$ On the one hand, we have locally issued preand post-reform coins and coin hoards strengthening the idea of considerably diverse subregional economies with areas boasting monetary continuity existing side-by-side with urban and rural pockets with weakening or even absent monetization; ${ }^{129}$ on the other hand, we face one of the most relevant provincial coinages within the Empire revealing only a small number of Sicilian coins circulating in the eastern Mediterranean and a far more substantial distribution in the Tyrrhenian sea. ${ }^{130}$ Although this approach is clearly not feasible for Cyprus, which seldom issued coins, there is another type of material evidence often, if not always, overlooked by scholarly analysis: terracotta roof tiles. Indeed, Rautman highlighted "the economic importance of Cypriot roof tiles ... for they formed the bulk of [seventh-century] KalavasosKopetra's imports far exceeding ceramics (fine, plain) and perhaps surpassed only by LRA1 amphorae". ${ }^{131}$ In particular, two types of locally made roof tiles reveal two distinct zones of production with different distributive networks: red fabric tiles manufactured in western Cyprus were shipped together with CRS from Amathos, whereas yellow fabric tiles produced in the eastern half of the island were distributed from the harbour of Salamis-Constantia. ${ }^{132}$

The analysis of the production and distribution of roof tiles, although chronologically limited to the seventh century, is nevertheless relevant to the economic discourse concerning seventh- and (partially) eighth-century Cyprus. It presents us with three important developments. The first has to do with methodology, for the sheer volume of this local Cypriot manufacture has never attracted the attention of scholars, although it is a clear example of prosperous production at the village level, hinging on local natural resources, impinging upon urban and rural building activities, and taking advantage of access to urban centres and harbours. If in Kalavasos-Kopetra this industry seems not to have survived beyond the late seventh century, it is possible to identify other types of manufacturing which continued at a "popular" level, like glass and metalworking. As will be seen, it is possible to surmise the existence of local workshops and exchange systems in Kalavasos-Kopetra well into the eighth century, drawing a picture that shows further similarities with Syria. ${ }^{133}$ In fact, this consideration leads me to the second development: with roof tiles we do not delve into luxurious productions or imports like marble in Late Antiquity. ${ }^{134}$ Therefore, we have the opportunity to reach down the 
social scale to incorporate the not-so-wealthy rural and urban classes. As Rautman states, "the volume of the commodities attests the success of local resource exploitation as well as the shape of the economy that it supported, as now it is possible to differentiate zones of non-elite economic exchange intersecting small-town sites". ${ }^{135}$

Although reconstructing local levels of production and patterns of consumption is almost impossible, nevertheless, and courtesy of local manufactures of fine and coarse pottery, amphorae, and building materials, we can trace a composite social network made of members of the administrative provincial government, the upper echelons of the military and fiscal apparatus, episcopal clergy, and urban-oriented aristocrats vis-à-vis the civilian population. The secular and ecclesiastical elites benefited from the surrounding fertile agricultural districts - as possibly in the plain of Kaleburnu-Galiporni - as well as good level of demand, allowing local rural communities to invest resources and maintain vital economies, as reflected in building endeavours (the eighthcentury barrel-vaulted churches). Even if we are facing a less monetized economy than Sicily or Syria, the evidence indicates that manufacturing and commerce seem to have expanded into economic activities in Cypriot cities and partially rural areas. ${ }^{136}$ Artisanal workshops and commercial activities could allow us to intercept sub-elite urban activities, whereas pottery kilns built at a semi-industrial level are documented in villages like Panagia or Dhiorios-Mersineri.

If the lack of post-1974 excavations left us in the dark concerning the residential and artisanal quarter documented at the Huilerie complex in

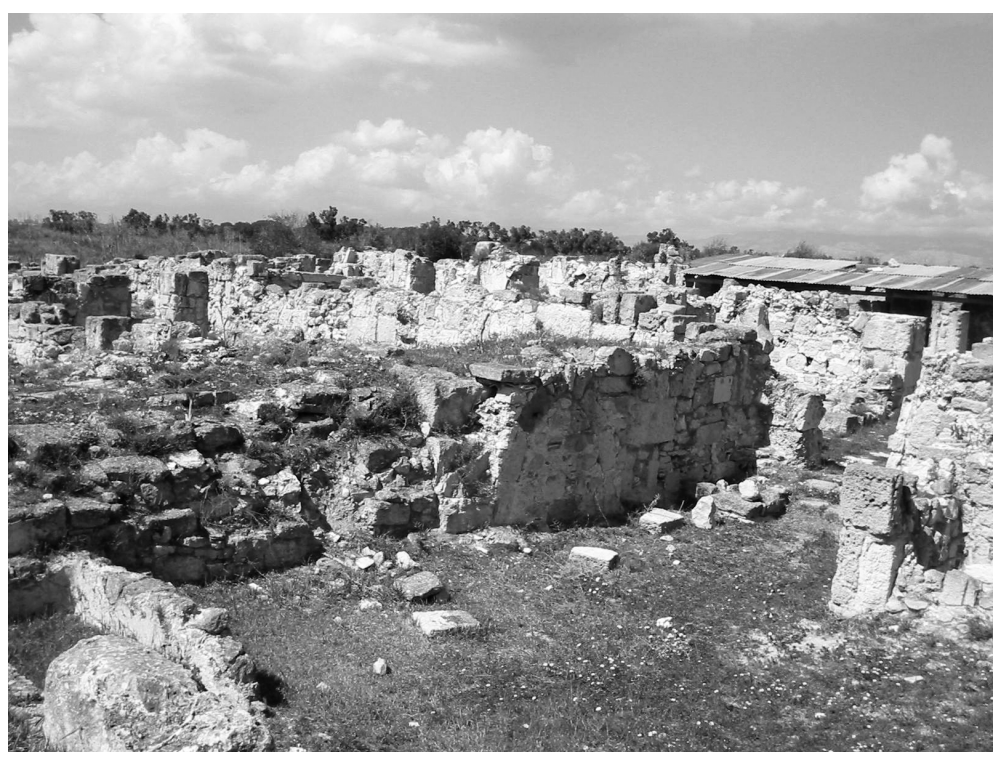

Figure 6.2 Salamis-Constantia, Huilerie complex 


\section{2}

An insular economy in transition

Salamis-Constantia, and if the lack of detailed publications does not allow us any further consideration of the residential (and possibly mercantile) quarter at Paphos, we can now turn to the spectacular discoveries at Polis-Arsinoe, where the post-classical urban landscape kept its organization and civic identity into the period under scrutiny and even beyond. ${ }^{137}$ Indeed, the "abundant late antique remains suggest a community perhaps not as wealthy as Salamis or Paphos but equally vibrant and active in his building projects". ${ }^{138}$ Only few of the excavated structures at Polis-Arsinoe have been adequately published: in particular, the so-called South Basilica and the larger area around it. However, it seems clear both from ceramic evidence and the presence of later burial (dated from the late seventh century on) that the church and the quarter centred upon it continued to operate well into the eleventh century. The basilica itself was originally built in the late fifth-early sixth century and largely refurbished and turned into a barrel-vaulted space sometime in the mid-tolate seventh century. ${ }^{139}$ As the excavators has argued convincingly the reconstruction of the church less than one century after its erection points less to the dramatic historical events supposedly engulfing the islands than to the economic and social resilience of some local Cypriot urban communities. ${ }^{140}$ This is enhanced by the presence of industrial spaces, commercial glass production, late seventh- and eighth-century CRS forms pointing to continuity of local exchange and productive patterns along with a vital regional trade, which may have also benefited from the easy coastal access and vicinity of overland routes. ${ }^{141}$ It is interesting to note that such an urban fabric consisting of workshops, roads, and burials grew up around local churches (one of which seems to have been protected by a wall) in a way that reminds us of Umm ar-Rasas in Syria.

As Walmsley has demonstrated, the market in cities of early Islamic Syria operated within a complex system of exchange. Moreover, industries and commercial markets were often found in addition to pre-existing structures even though there were differences between larger urban-like target markets and more locally oriented distributive complexes. More in tune with the latter category, Walmsley has revealed that "in Umm ar-Rasas we find thirty shops lining two streets including units within securable compounds and a selfcontained ecclesiastical complex with attached markets". ${ }^{142}$ Although in PolisArsinoe we cannot document the advanced level of economic activity shown by productive structures and commodity exchange in villages, towns, and cities of Syria (and therefore the comparison between a Syrian rural township and a Cypriot city should come as less of a surprise), yet we can observe a relatively stable economy with agricultural, civic, and religious activities continuing throughout the eighth century and during the period from the ninth to the eleventh century. ${ }^{143}$

This stability included more rural productions, such as that indicated by olive oil presses housed in one of the rooms attached to one of the abovementioned churches. ${ }^{144}$ Similar structures have also been found in SalamisConstantia (the Huilerie complex), Alassa, Paphos, and Dhiorios-Mersineri, 
as well as evidence of food-processing activities, for instance sugar cane and possibly salt extraction, and above-mentioned factories producing glass vessels, such as those found at Saranda Kolones and Soloi. ${ }^{145}$ Here a further comparison with the urban landscape of the above-mentioned city of Amorium may be helpful. In Amorium the residential lower city includes foci of settlement that preserve the late antique organization of public buildings, streets, and public and private spaces arranged in a grid, within which the eighth- to ninth-century city developed. ${ }^{146}$ Indeed, archaeology has yielded traces of streets and numerous wells, public buildings (like the so-called bathhouse complex), four churches (including the Lower City Basilica), and, above all, artisanal infrastructures, which point to a good level of economic activity throughout the seventh and the ninth centuries. ${ }^{147}$ In particular, the continuing economic vitality is indicated by wine pressing and treading installations, the absence of a break in the sequence of bronze coin issues throughout the mid-ninth century, and the continuous role of locally produced pottery. ${ }^{148}$

The recent discoveries in Amorium clearly echo the evidence unearthed at Salamis-Constantia and Polis-Arsinoe on Cyprus, as well as at Gortyn on Crete, for in all evidence, as Lightfoot concludes,

in the second half of the eighth century some urban centres remained and the countryside continued to provide the basic resources for subsistence and also surplus wealth. [Things being so] those to whom any surplus accrued should not necessarily be regarded as behaving in the same way as the local elites of earlier times. ${ }^{149}$

Indeed, as previously hinted at, this consideration seems equally relevant to the islands of the Byzantine Mediterranean as well as Syria and Palestine. ${ }^{150}$ If Amorium allows us to reassess the role played by Anatolia in the survival of the Byzantine Empire, the evidence from Cyprus as paired with that from Gortyn and Sicily enables us to demonstrate the resilience of islands as far as agriculture and social welfare are concerned. Therefore, the combined evidence from Amorium and the so-called insular economic system points not to the change in inland patterns of trade and distribution but to their reduction in scale while narrowing the gap with the more economically resilient areas of Syria and Palestine. ${ }^{151}$ So it seems possible to surmise that even some areas of Anatolia could be partially in tune with regions of the eastern Mediterranean in the seventh and eighth centuries, when - as we have already documented fragmentation and simplification of the long-distance exchange system and regionalization of production and distribution (shown by ceramic evidence) did not imply that "cities, towns or [rural] settlements could not form the basis of effective commercial activity, especially where supplemented by the presence of troops merchants, pilgrims, and exchange of goods". ${ }^{152}$

Among the latter, one should also include human commodities or slaves, which were the focus of a real but invisible commerce, which has left almost no trace in the literary sources or archaeological record. Indeed, Michael 


\section{An insular economy in transition}

McCormick has correctly argued that the demand for slaves at the time was increasing in the Arab world, with Western Europe (the Carolingians) and Byzantium feeding their voracious appetite for slaves and the slave trade in turn fuelling the expansion of commerce more generally between Europe and the Muslim world (especially from the mid-eighth century onwards). ${ }^{153}$ It would be interesting to understand the role of Cyprus in turning this important wheel of medieval economy. Indeed, we possess references to Cypriots taken prisoner and relocated to Muslim lands in the seventh, eighth, and ninth centuries. One is the story of a Jewish slave escaping from Saracen Syria and settling at Amathos as a convert in the late seventh century; ${ }^{154}$ another is the previously mentioned passage of Anastasios of Sinai referring to the Cypriots working in a Caliphal household on the Dead Sea in the early eighth century; and finally, a third example is the forced removal to Syria of large numbers of islanders in 743 (all returned home one year later). ${ }^{155}$ As I have already discussed, al-Tabarī reports that the Abbasid Caliph Harun al-Rashid raided Cyprus in 805/6 and transplanted 16,000 Cypriot prisoners to Raqqa; among them was the local archbishop, who, together with other notables, was allowed to go back to the island after the payment of a 2,000-dinar per capita ransom. ${ }^{156}$

It is possible to link the latter episode with the new system and scale of slave hunting following the Muslim invasion of Sicily in the ninth century. McCormick states: "the Arab raiders were as eager to collect saleable men and women as to plunder treasure... They expanded profits by entering the ransom business, [a] process ... best attested for the Cretan Arabs". ${ }^{157}$ Remarkably, late eighth- and early ninth-century sources mention exchanges of prisoners. For instance, Agapius refers to deportations of Cypriots staged by Mu'äwiya and the Umayyad Caliph al-Walìd, who installed them along the coast between Tyre and Sidon. ${ }^{158}$ As the Arab slave trade grew so did the importance of markets located near the hunting grounds. ${ }^{159}$ Indeed, John Kameniates, writing in the tenth century, refers to the Cypriot coasts as places where Arab slave traders could dock, stay briefly, and even take a bath before sailing back to Syrian harbours. ${ }^{160}$

In sum, the evidence I have presented should enable us to identify Cyprus as a convenient hub along transregional and intraregional networks frequented by travellers and merchants (as well as armies and diplomats). One of the main trading routes identified by McCormick began in Constantinople and linked the Aegean with the southern shore of Asia Minor, eventually reaching Cyprus. ${ }^{161}$ Here localized and medium-distance exchange systems coexisted, with the state playing a major role in the movement of goods. These exchange systems mainly involved the major political centres, but they also included cities where aristocratic wealth remained concentrated, such as Ephesus, Gortyn, and even Amorium (although the latter was located on the Anatolian plateau). ${ }^{162}$ Cyprus was an ideal place to which the Byzantine Empire and the Caliphate could attract traders and merchandise from all across the eastern Mediterranean basin thanks to its blurred and volatile political status. 
Therefore, the location of the island at the intersection of two main regional economies benefited from the commercial routes that reached outside the territories within the imperial boundaries.

The width of the sea from the Syrian coast is two days of navigation (if the sea is calm) and from that side of Cyprus to the opposite it takes the same time. [For instance] in Cyprus one can find the mastic, which is sold by the Byzantines to the countries of Islam. ${ }^{163}$

Thus it should come as no surprise that seventh- and eighth-century Cyprus had a multifaceted relationship with the Islamic world, for merchants, pilgrims, and possibly slaves moved together with raiders and armies to and from the Levant; and with them of course travelled bulk goods and petty commodities.

The concept of a middle ground can once again be evoked in terms of redistributive networks, with fellow villagers and townspeople on one side and strangers and enemies, who tended to exchange goods by theft and violence, on the other side. ${ }^{164}$ This network of exchange seems to have become thoroughly integrated into the political and social relationship without any material dependence. Indeed, Cyprus was located between Constantinople and the Muslim regional, subregional, and microregional productions underpinned by the high productivity of Nilotic agriculture. It was also a midway point between the Empire and Syria and Palestine and their localized economies, focused on continuous demand from such urban centres as Jerusalem, Pella, Jerash, Scythopolis, and Aleppo. ${ }^{165}$ In turn, Cypriot elites were influenced by this set of interlocking economies, which affected consumption and levels of demand as well as the intensity of local production and regional exchange. Indeed, even at this level we see a persistence of artisanal production, expressed mainly in the different varieties of local fine and coarse ware and of containers for local agricultural products, but also evident in other types of manufacture on Cyprus, like glass.

Of course, such production could not counteract the general trend of localization and regionalization of monetary exchange experienced by the island, as well as the rest of the Empire, or offset the centrality of the Byzantine fiscal and military apparatus in the island's social, economic, and political trajectories. Nor could it reverse the decline in interregional exchange within the Empire during the passage from Late Antiquity to the early Middle Ages. But the economic prominence of Cyprus does help us draw a different picture of its history: a picture in which the island is a strategic stepping stone in the main flows of trade; a picture in which a noman's-land is recast as a frequented and attractive hub for travellers and goods - the island of merchandise, goods, and populous cities portrayed by al-Muqaddasī; a picture, finally, that supplants a supposed eastern Mediterranean caesura between two opposing empires with a middle ground between two different cultures. 


\section{Notes}

1 The current chapter is based on the article I published in Dumbarton Oaks Papers 65-6 (Zavagno, 211-12). This partially because I still regard the picture I drew in the article to be methodologically sound and analytically valid, and partially because few contributions on the topic have appeared since I wrote it, although two clearly deserve to be included in this chapter. These are the recent volumes edited by Parani and Michaelides (2013) and by Stewart, Davis, and Weyl Carr (2014).

2 Wickham (2005), 702-3.

3 Laiou and Morrisson (2007), 54.

4 Wickham, (2005), 788-9; also Haldon (2012a) and Haldon (2016).

5 Wickham, (2005), 714.

6 Papacostas (1999), 112-13.

7 Ammianus Marcellinus, I, XIV.8

8 On the LRA1, see Dark (2001), 38-40; on CRS, see Meyza (2007). See also Wickham (2005), 715.

9 Papacostas (1999), 113.

10 Dark (2001), 34; Armstrong (2009), 165.

11 Armstrong (2009), 166-8.

12 Walmsley (2008), 326-39.

13 Armstrong (2009), 168-77.

14 Randall (2013); Armstrong (2006); Vroom (2012a), 368-70.

15 Randall (2013), 276-8; Vroom (2012a), 370-3. This typology is often labelled as a later variant of the LRA2 type.

16 Armstrong (2006), 21.

17 Randall (2013), 278.

18 Especially if one considers that an occasional walk around the latter sites could allow even an untrained eye to recognize thousands of sherds ranging from the classical well into the medieval period.

19 Vionis (2013a), 114; see Chapter 4, n. 297.

20 Ibid., 115.

21 Cau Ontiveros and Mas Florit (2013), 38-9.

22 Wickham (2005), 791.

23 Laiou and Morrisson (2007), 59.

24 Haldon (2010a), 83. For the archaeology of Byzantine islands, see the contributions included in Zanini (2013a). Also Randall (2013) and Armstrong (2009).

25 Christides (2006); Mansouri (2001).

26 Ibn Hawqal (1964, I, 184). Born in Nisibis, ibn Hawqal travelled extensively during the second half of the tenth century. He was asked by another famous contemporary geographer, al-Istakhrī, to edit and complete the latter's work, which he published with many alterations and additions, often based on eyewitness observations. He completed the maps drawn by his predecessors but paid more attention to the text, which appears independently of the maps. See Christides (2006), 127.

27 Reported in Cobham (1908), 5.

28 al-Mas'ūdī (1989, 320-4). See also Christides (2006), 130; and Mansouri (2001), 84.

29 Compared to the 170 pages dedicated to seals and coins. Metcalf (2009), 229-46.

30 For a detailed list of these contributions see Chapter 1.

31 Rautman (2003); Megaw (2007); Randall (2013); Armstrong (2006); Armstrong (2009).

32 Armstrong (2009), 157.

33 Cosentino, (2013a), 72-4.

34 Brubaker and Haldon (2011), 495. 
35 Armstrong (2009), 158; Rautman (2001), 253-4.

36 Dark (2001), 47.

37 "In excellence Cyprus falls behind no one of the islands because it is rich in wine and oil and uses home-grown wheat. There are mines of copper ... in which are produced sulphate of copper and copper-rust useful in the healing art ... [T] he trees [were] cut down for melting of copper and silver; and of further help was shipbuilding" Strabo, Geographica 14.6 (681-5), in Cobham (1908), 3.

38 Venantius Fortunatus, De Vita Sancti Martini (1996, 138; Gregory the Great, col. 493). For Ammianus and Hierokles, see above and Chapter 2.

39 In truth the passage from the Song of Songs referred to "botrus Cypri", which is a branch of the alkanna tintoria plant.

40 Armstrong (2009), 164.

41 Vroom (2005), 51; Touma (2001),168; Hayes (2007), 437; Armstrong (2006), 21-2; Manning, Monks, Sewell, and Demesticha (2000). See also the recent contributions of Stella Demesticha (2013) and (2014).

42 Nea Paphos: Demesticha and Michaelides (2001); Amathos: Touma (2001), 267; Kourion: Hayes (2007), 437; two other places in Cyprus: Lund (2007), 788.

43 Papacostas (1999), 70.

44 Vroom (2007), 278-82.

45 Rautman (1999), 378-9; Demesticha and Michaelides (2001), 292; Demesticha (2013), 176-7; Touma (2001), 268.

46 Smadar Gabrieli, Jackson, and Kaldeli (2007), 792. On the Kourion finds, see Hayes (2007), 437.

47 Ballet (1995), 17; Smadar Gabrieli, Jackson, and Kaldeli (2007), 792.

48 See Given and Knapp (2003), 173, and Dark (2001), 39.

49 Arthur (1989), 85.

50 Wickham (2005), 759-62.

51 Hayes (1991), 495-502; also Touma (2001), 269. Some specimens have also been found in Lymira and they appeared in old Cairo in eighth- to ninth-century contexts and in Pella in mid-eighth-century ones. Vroom (2005), 251.

52 Given and Knapp (2003), 173.

53 Vroom (2007), 271.

54 Walmsley (2008), 329.

55 Ibid. For Cyprus, see Zavagno (2011-2012), 147 with further bibliography.

56 Hayes (2007), 436.

57 Ballet (1995), 17.

58 Hayes (2007), 436. The flasks are exhibited at the Limassol Castle Museum.

59 Touma (2001), 268-70; Jacobsen (2004); Hayes (1991), 487-9; Baranky (1940-1942), pp. 76-7.

60 McCormick (2001), 590.

61 Magness (2003), 152; Hayes (1991), 479-85.

62 Armstrong (2009), 165. On these cooking pots, see Dark (2001), 34, 43-50; Catling (1972); Armstrong (2006), 165-6; Armstrong (2006), 20-1; Rautman (1998), 89; Rautman (2001), 250-1; Vionis, (2013a), 27-8.

63 Vroom (2005), 254.

64 Vroom (2012a), 368-70.

65 McCormick (2001), 209.

66 Vroom (2005); Armstrong (2006), 24-7.

67 Vroom (2005), 255-7.

68 Zavagno (2011), 462-6.

69 "Serious study of Arab-Byzantine coinage began with the British Museum catalogue of John Walker published in 1956. He listed around 200 coins ... He concluded that the great majority of Arab-Byzantine types were issued in a relatively short time at the end of the seventh century. [But it was only when] 
Tony Goodwin had begun his pathbreaking work ... [so] that he identified and classified different types and put the studies of this important coinage on new basis" (Foss 2008, viiii). See also Goodwin (2005); Goodwin and Philips (1997), $61-87$.

70 Ibid., 25.

71 Zavagno (2011), 473.

72 Zavagno (2011-2012), 148 with further bibliography. Indeed, this type of coin has been yielded at Saranda Kolones (four specimens), Salamis-Constantia (six specimens), and Kourion (six specimens).

73 Metcalf (2009), 456; Brown (2007).

74 Metcalf (2009), 589.

75 See Chapter 2. The absence of Ba'albek among the above-mentioned Syrian mints owes to the fact that the local mint was closed and absorbed by that of Damascus in 683-4. Goodwin (2005), 65.

76 Jund in Arabic means an administrative and military province. See Haldon (2010c), 2.

77 Metcalf (2004), 500-4.

78 Metcalf (2009), 482. See Chapter 4 n. 144.

79 Papacostas (1999), 74.

80 Ibid., 75.

81 Young (2007).

82 Ibid., 486-9. For Dhiorios, see Catling (1972), 77.

83 Young (2007), 511.

84 For a detailed reconstruction of the origins and architectural developments of the site, see Petre (2012), 319-57. See Chapter 1 n. 224.

85 Rosser (1985), 97.

86 Eutychios of Alexandria, 55-6; Papacostas (2012), 96.

87 Hayes (1980), 377-8, and Armstrong (2006), 19-22. Also Dikigoropoulos (1961), 326. On the ceramics imported to Cyprus from Syria-Palestine, see also Haldon (2012a), 105 with further bibliography.

88 Touma (2001), 276.

89 Christides (2006), 64-5; Karageorghis and Maier (1984), 300-6.

90 al-Balādhurī (1916, XIII, 236); also Ibn al-Athīr (2008, 137). For a much later source dated to the thirteenth century, see Mansouri (2001), 42-5. On this episode, see Kyrris (1984), 155; also Kyrris (1997), 628.

91 Papacostas (1999), 212; see also Christides (2006), 51-63; Metcalf (2009), 262-4; and Megaw (1950a), 108-9.

92 Christides (2006), 64-5; Hayes (1980), 378.

93 Vroom (2012a), 355-8.

94 Wickham (2005), 785-7.

95 Vroom (2003), 54; Vroom (2012a), 364-7; also Randall (2013), 278; For Saranda Kolones, see Hayes, (1991), 495-502; for Kourion see Hayes (2007) 435.

96 Dark (2001), 118.

97 Jackson, Zelle, Vandeput, and Köse (2012).

98 Ibid., 94.

99 For Paphos as a centre of CRS production, see Meyza (2007); also Kenkel (2007a), 142-3.

100 For Pednelissos, see Kenkel (2007a); for Lymira see Vroom (2005) and Vroom (2007); for Cilicia in general, see Zoroglu (2005); for Gortyn, see Cosentino (2013b), 100.

101 Vroom (2005), 250.

102 Armstrong (2009), 174.

103 For Balboura, see Armstrong (2006), 24-5, and Coulton (2012).

104 Armstrong (2006), 26; Pellegrino (2002). 
105 Armstrong (2009), 170-1.

106 Haldon (2012a), 107.

107 Rautman (1998), 85-9; Rautman (2001), 254-6.

108 Armstrong (2006), 167; Armstrong (2006), 24-6; Rautman (1998), 85-8; Smadar Gabrieli, Jackson, and Kaldeli (2007), 799-801.

109 Rautman (1998), 89; Armstrong (2006), 21-3.

110 Walmsley (2007), 69-71.

111 Rautman (1998), 92.

112 Armstrong (2009), 167.

113 Vroom (2012a), 384.

114 Haldon (2012a), 108; Vroom (2012a), 391.

115 Vroom (2007), 278.

116 Armstrong (2009), 165-6.

117 Catling (1972), 57ff.; Armstrong (2006), 22-3.

118 Walmsley (2008), 341.

119 Armstrong (2009), 160; Armstrong (2006), 22-3.

120 Armstrong (2009), 169. Also Manning, Monks, Sewell, and Demesticha (2000), 249.

121 Ibid., 167.

122 Walmsley (2008), 314-16.

123 Molinari (2013), 104.

124 Ibid.; also McCormick (2001), 519ff.

125 Bruno and Cutajar (2013), 26; for the Venetian Lagoon, see McCormick (2001), 523-31; for Comacchio, see Gelichi et al. (2006); Gelichi (2012); and Vroom (2012a); for the concept of emporion, see Wickham (2005), 688-92

126 Bruno and Cutajar (2013), 26.

127 Ibid., 27-8.

128 Walmsley (2012), 329-30.

129 Walmsley (2010), 39.

130 Molinari (2013), 105. See also Prigent (2006) and Nef and Prigent (2006), 9-37.

131 Rautman (1999), 389.

132 Rautman (2001), 254-5.

133 Walmsley (2008), 342-3.

134 Papacostas (2001), 115-16.

135 Rautman (1999) 391.

136 Walmsley (2008), 348-9.

137 Caraher and Papalexandrou (2012), 282.

138 Caraher, Moore, Olson, and Papalexandrou (2013), 79.

139 Ibid., 83-90.

140 Ibid., 91-2.

141 Caraher and Papalexandrou (2012), 279-80.

142 Walmsley (2012), 323.

143 Caraher and Papalexandrou (2012), 282.

144 Ibid., 278.

145 Hadjisavvas (1992); on food processing, see Papacostas (1999), 71; on glass production, see above and Metcalf (2009), 250 with further bibliography.

146 Ivison (2007), 38.

147 Lightfoot and Lightfoot (2007), 48-57; Lightfoot (2012).

148 Lightfoot (2007); Lightfoot (2009).

149 Lightfoot (2012), 189-91.

150 Kennedy (2010).

151 Cosentino (2013a), 72-3.

152 Lightfoot (2012), 177.

153 McCormick (2001), 759-77. 
180 An insular economy in transition

154 Metcalf (2009), 305 with reference to the source.

155 Agapius (1912, 511-12); al-Balādhurī (1916, XIII, 238); al-Ṭabarī (1985-2000, VII, 227).

156 al-Balādhurī (1916, XIII, 238); al-Ṭabarī (1985-2000, VIII, 320-1).

157 McCormick (2001), 769.

158 Agapius (1912, 480, 511-12). See also Christides (2006), 43.

159 McCormick (2001), 770.

160 John Kaminiates $(1973,77)$.

161 McCormick (2001), 589.

162 For Ephesus, see Zavagno (2009), 95-128.

163 al-Istakhrī $(1870,51)$.

164 White (1991), 99.

165 Hayes (1980), 377-80; Ballet (1995). High-quality local ceramics were produced well into the 8th century; see Zavagno (2011), with further bibliography. 


\section{Aftermath and conclusions}

\section{Cyprus in the ninth and tenth centuries}

As this book has tried to present a different perspective on the history of Cyprus in the transition from Late Antiquity to the early Middle Ages, arguments of social continuity, economic resilience, and urban and rural developments have been presented as a counter to the traditional notion of economic decline and social demise stemming from the catastrophic Arab raids and matched by the localization of the eastern Mediterranean exchange system. One may, however, question the chronology of this framework and wonder if the points I have made in the previous chapters hold any validity for later centuries. I propose that without losing track of the distinctiveness of the period under scrutiny we should briefly look beyond the chronological scope of the book thus far and trace the historical developments of the island in the period from the late ninth to the eleventh century. Here the unavoidable starting point of any narrative has always been the recovery of the island by the Byzantines in 965 as mentioned by John Skylitzes and George Kedrenos. ${ }^{1}$ We possess only few and laconic scraps of information about the Reconquista, but we know that under the reign of Nikephoros Phokas a patrician and strategos named Niketas Chalkoutzes ousted the Arabs and returned Cyprus to the imperial fold. ${ }^{2}$ As Metcalf summarizes:

The social and economic reality in the aftermath of the reconquest was that no doubt lands in Arab possession were regarded legally as having been recovered by the force of arms ... a kourator of Cyprus was appointed [as] principal official with responsibility for the whole province. $^{3}$

In truth, as Browning stresses, the Byzantine expedition against Cyprus stemmed from a strategic situation dramatically different from that of the late ninth century and the beginning of the tenth century. ${ }^{4}$ Indeed, Dikigoropoulos, Beihammer, and Lounghis, among others, have pointed out that at that time the Byzantines had failed at least once (if not twice) to bring the island under full military and administrative control. I have already mentioned the 


\section{2}

Aftermath and conclusions

supposed campaign staged under Basil I, which should have made Cyprus a theme, although only for few years around $874-76 .{ }^{5}$ Since the episode is mentioned only by Constantine Porphyrogennetos, it remains rather unclear if a strategos was installed on the island or if - as the sigillographic evidence and the Taktikon Uspenskij reveal - we might identify a Byzantine administration headed by archontes and military authorities in collaboration with the local elites. ${ }^{6}$ The second, and better documented, event occurred in 911, when the Byzantine fleet with a commander named Himerios at its head used Cyprus as a launching point for a raid against Crete and the Syrian-Palestinian coast. ${ }^{7}$ Himerios's failed expedition triggered a ruinous counter-attack against Cyprus staged by the Arab fleet under the command of the renegade Damianus, documented by the well-known letter of Patriarch Nicholas Mystichos to Caliph al-Muqtadir. As we have seen, the patriarch attempted to play down the whole episode (involving 177 Byzantine ships!) and absolved the Cypriots of any suspicion of having collaborated with Himerios. ${ }^{8}$

The two failed attempts have been often interpreted as clear signs of the unwavering attachment of the Cypriots to the "Byzantine motherland", which was shaken only by the iconoclastic controversy. For instance, Kyrris states: "Even though [we can] speak of friendly relations between Greeks [sic] and Arabs in Cyprus, [we must] underline the Greeks' inner unloyalty to the Arabs which contributed to the Byzantine reconquest of 963/4". 9 Therefore, the return of the Byzantines to the island was only the natural conclusion of a long journey started in 649 to completely reunite Cyprus with its political and religious motherland. It was therefore to be regarded as another caesura, an "absolute coupure", in the words of Malamut, in opposition to the catastrophe of the seventh-century Arab invasions. ${ }^{10}$

In truth, this is once again more an exercise in wishful thinking than a reflection of the reality on the ground, especially if one considers that the reintegration of Cyprus into the Empire received very little celebratory attention in the Byzantine sources. ${ }^{11}$ In fact, much as with the mid-seventh-century Arab raids, one can agree with Papacostas that

the archaeological record does not betray any significant shift in the later tenth and early eleventh centuries: there is no evidence for an increase in building activity until the remarkable construction boom of the Comnenian period and very few among the surviving structures on the islands can be dated to the intervening decades. ${ }^{12}$

Moreover, as Metcalf has argued convincingly, signs of what the traditional historiography labels, as administrative and economic recovery cannot be traced in the numismatic and sigillographic records before the last third of the eleventh century. ${ }^{13}$ Finally, the dearth of literary, documentary, and material sources does not enable us to investigate the reasons that lead to the choice of the inland centre of Nicosia (right in the middle of the Measoria Plain) as the new capital of the island from the late tenth century onwards. Papacostas has 
remarked that Salamis-Constantia had become a rural settlement by this time, and therefore no attempt was ever made to revive the old capital. ${ }^{14}$ Veikou has also stressed the importance of considering this relocation as a reflection of the island's overall settlement pattern and political change. ${ }^{15}$

One must admit that the latter conclusions seem not completely in tune with the few shreds of material evidence we possess for Salamis-Constantia. In the silence of written sources, we rely on the available archaeology, such as the two solidi of Constantine VIII and Basil II uncovered in the area of the Campanopetra, which - according to the excavators - points to the continuity of the local monastic community. ${ }^{16}$ In a similar vein, Stewart has convincingly argued that the basilica of Saint Epiphanios was further restored in the early ninth century and remained in use until the eleventh century (the supposed transferral of the saint's relics in the late ninth century has since been demonstrated to be fiction). ${ }^{17}$ The sigillographic evidence shows the archbishops continuing to reside within the city (if not in Saint Epiphanios or the nearby monastic church of Saint Barnabas), whereas the eleventh-century Book of Curiosities mentions the harbour as still active. ${ }^{18}$ It is, therefore, safer to assume, in the light of the numismatic evidence presented by Metcalf, that Nicosia replaced Salamis-Constantia as the capital from the mid- to late eleventh century. $^{19}$

In this light, it is worth mentioning here that a recent reassessment of the archaeological, topographical and documentary evidence concerning the Cypriot urban settlement pattern has pointed to the existence of a versatile and asymmetrical organization of urban functionalities on the island. ${ }^{20}$ In other words, Cyprus seems to have experienced a rather fluid response to the need for a capital city; a response more in tune with the variable shear politicalmilitary stress endured by the island due to its position at the edge of two empires. In this light, and although the research is still in its infancy, it would be possible to conclude that Salamis-Constantia clearly retained a role as a vital commercial hub, ecclesiastical (and pilgrimage) focus, while its importance as Byzantine administrative, bureaucratic and above all military centre slowly faded in favour of the northern coast with Kyrenia at its very centre. This in turn would contribute to explain the rather inconclusive impact of the Byzantine Reconquista of the island in 965 for the return of Cyprus under full Byzantine control de facto did not impinge upon the political and administrative strategies the local elites had in place from the eighth century onwards; neither it seems to have altered the settlement activity of the local population or the local economic infrastructures. In other words, rather than looking at 965 as a return of the island to a "Byzantine innocence", we should regard it as a favourable episode of the confrontation with the Muslim powers (now on the defensive in the Eastern Mediterranean), which - but only in the long run - allowed Cyprus to be recaptured by the increasing Byzantine gravitational pull vis-à-vis the receding strength of the Muslim one.

As I will return on this in few moments, and considering the dearth of literary and material sources from the mid-ninth to early eleventh century, it is worth 


\section{4}

Aftermath and conclusions

to examine Cyprus from a comparative perspective. In Sicily, for instance, it seems as though the ninth-century Muslim conquest left the Byzantine state structures almost undisturbed. Moreover, recent analysis of the ninth- and tenth-century locally produced ceramic assemblages as well as the changes in rural settlement pattern on the island has revealed that only in the late tenth and early eleventh centuries did material culture begin to more clearly reflect with an Islamic influence, although a wide range of cultural identities continued to coexist on the island. ${ }^{21}$ This change must have occurred after the creation of a new capital (Palermo) and the fall of the last Byzantine outpost on the island in 902 , but was in tune with the revival of eastern and western Mediterranean trade from the second half of the tenth century onwards. ${ }^{22}$ From an economic standpoint, during the tenth and first half of the eleventh century Sicily was part of a network of exchange and trade that included Christian (mostly on the Tyrrhenian coast) and Muslim regions. ${ }^{23}$ This has a lot to do with the agricultural potential of the island as well as its increasing links with North Africa after the Arab conquest.

In Syria and Palestine, as Walmsley has clearly demonstrated, the ninth century was "a period of dramatic, rapid, and systemic change in ceramic, stone, and perhaps metal working traditions with the unbroken typological and technological lines stretching back centuries into antiquity subjected to rigorous review". ${ }^{24}$ However, it was the continued complexity of these traditions that allowed the introduction of new high-quality wares and at the same time the resilience of wider distribution networks. ${ }^{25}$ As Taxel's recent studies have documented, the material culture should be supplemented by the analysis of the development of settlement patterns. In fact, the survey of the Palestinian coastal areas and the rural hinterland of Ramla, Ludd, and Yubna has revealed that settlement dynamics throughout vast stretches of Palestine were not uniform, for some settlements experienced territorial and economic development, a few others settlements were newly built, some simply continued as they were, and others declined or were deserted already in the eighth century. ${ }^{26}$ Nevertheless, the advent of the Abbasids in the mid-eighth century represents the real turning point for the region, which experienced political marginalization due to the fiscal reorganization of the Caliphate. Taxes were now conveyed to the newly built Iraqi capital, Baghdad, and used to subsidize Iraqi agriculture and commerce. ${ }^{27}$ This, however, means there was no economic crisis (although the 749 earthquake must have cause real havoc across the Levant) but rather a reorientation of regional and interregional exchange networks and a realignment of local productions.

With these two rather brief examples in mind, one can turn back to Cyprus. Here, as I have often said, we possess no more than a few glimpses of material information. One of them is the rediscovery of an inscription at Syngrasis (a few miles away from Salamis-Constantia), which Papacostas has convincingly used to date the local dome-in-cross square church to the late eighth to early ninth century. ${ }^{28}$ Stewart has provided us with a second important piece of the Cypriot jigsaw by arguing for a ninth-century date for five multiple dome 
basilicas across the island based upon their fabric, design, and archaeology. ${ }^{29}$ Among these is the well-known Agia Paraskevi church bearing the famous aniconic fresco that local artists painted using as a model the ninth-century painted cross of the White Monastery of Sohag in Egypt. ${ }^{30}$ A good addition to the architectural evidence is provided by the archaeology advocating for urban continuity in Salamis-Constantia and Polis-Arsinoe until the early eleventh century, the presence in Paphos-Saranda Kolones of a glass-factory that also yielded shards of ninth-century Glazed White wares (GWW), and the continuous production and circulation across the Mediterranean of CRSW, indicating a trade network functioning more or less independently of Constantinople. ${ }^{31}$ Combining this evidence with the documented productive and distributive networks of Dhiorios cooking wares allows us to point to the resilience of commercial and economic activities in Cyprus well into the eighth century and possibly even into the ninth. ${ }^{32}$ This had much to do with the interaction between the Arabs and the neighbouring regions using Cyprus as a middle ground.

In this regard, by far the most fascinating and intriguing documents shedding light on the social and cultural life of Cyprus in the late ninth and tenth centuries are two hagiographical works: the Life of Saint Constantine the Jew and the Life of Saint Demetrianos, Bishop of Khytrea. The former mentions the famous episode of the Muslims coming to a church to pray; the latter reports on the embassy to Baghdad led by the saint in the early tenth century to free some fellow countrymen taken as captives after an Arab incursion on Cyprus. ${ }^{33}$ We can clearly see how these two episodes reflect an environment producing the style of frescos at Agia Paraskevi as well as the passages in the Acts of Nicaea II mentioning Cypriots coming and going from Syria or the cedar trunks sent to Jerusalem. They also echo the words of Nicholaos Mystikos discussing numerous Arab communities on the island at the beginning of the tenth century. More importantly, they found a significant parallel in the descriptions of Cyprus sketched by contemporary Arab geographers. Here, although Sicily more than Cyprus belonged to the Arab literary scope of writers like Ibn Hawqal or al-Muqaddasī, the island is nevertheless revealed in their works as adhering to its stereotypes of fertility and abundance. For instance in the tenth century al-Istakhri was already praising the wealth of Cyprus, whereas Ibn Hawqal pairs Cyprus with Crete as prosperous in commerce. ${ }^{34}$ Al-Balādhurī and al-Muqaddasī, as we have seen, also convey similar messages. For these, and even for later authors like twelfth-century al-Idrīsi, it seems that the score on Cyprus had been settled already in the seventh century and that the few violent hiccups that came later were the natural consequence of constant interaction less in tune with the idea of a frontier than with that of a middle ground. ${ }^{35}$

In this light it is worth noticing that the model of a middle ground as a space defined by frequent negotiations and both geographically and ideologically constructed has been used to frame the cultural, social, and political interactions in different areas of the Byzantine Empire during its millenarian 


\section{6}

Aftermath and conclusions

history. It suffices here to mention the contributions of Ralph Lilie on the twelfth-century Turkish-Byzantine frontier and the recent work of Joahnnes Preiser-Kapeller focused on thirteenth- to fifteenth-century maritime Asia Minor. ${ }^{36}$ Indeed, the former defines the relationship between the Seljuks and the Byzantines as a balance of state powers that could not eradicate each other but were forced to coexist and arrange peculiar forms of socio-political interactions punctuated by antagonistic and violent episodes. ${ }^{37}$ The latter, instead, identifies the middle ground as often established at the geographical edges of empires where political and cultural authority overlapped. This is particularly evident in the case of those portal and coastal zones acting as links between the Anatolian hinterland and the Mediterranean at the end of the medieval period. In these zones, agreements were often ratified by local representatives of western and Turkic polities because they were more familiar with the socio-political, economic, and even cultural and religious liquidity of the local areas where Muslim powers often avoided direct involvement. ${ }^{38}$ With this in mind, it is interesting to note that these zones are even peculiarly defined in the Muslim sources. Indeed, when examining the maps drawn by some twenty-three ninth- to fourteenth-century Arab geographers, Brauer concluded that

boundaries were completely omitted [as] each country was conceived of as being a core including its centre and power and a periphery separating that core from the nearest adjacent country ... the concept of boundaries ... is therefore not that of a sharp transition from one political entity to the next but rather of cultural interpenetration of adjoining communities. ${ }^{39}$

In this manner, and returning to Cyprus, what seems to emerge is a picture of an island where economic, social, and cultural life certainly suffered the repercussions of the fragmentation of the eastern Mediterranean exchange networks as well as the confrontation between the Umayyad Caliphate and the Byzantine Empire. However, much like Syria and Palestine, Cyprus showed a degree of resilience in urban and rural settlements, local productive and distributive structures, and aristocratic vitality even in the eighth century. Therefore, as in the Levantine regions, the ninth and tenth century may have been a low point caused by the political upheavals leading to the Abbasid revolution or more likely the occasion for an adjustment of the political and economic local structures allowing the island to continue playing the role of a middle ground.

However, in Cyprus we are missing the litmus tests available for Sicily and Syria-Palestine, as we possess little or no material evidence on a par with Sicilian or Syrian ceramics or numismatic evidence like the coins minted in Syracuse and spread across the whole Mediterranean well into the ninth century. ${ }^{40}$ We are also faced with just a few casual mentions of the island in one of the most important documents of the period, the Geniza papyri. This 
may lead us to conclude that as Byzantine exports were often mentioned in eleventh-century Arab sources, Cyprus played a lesser role as a hub for travellers and merchants than did Attaleia (modern Antalya). ${ }^{41}$ However, although Attaleia had a rich agricultural hinterland, it was also the entry hub for trade with the Muslims via Cyprus and Syria ${ }^{42}$ and a stop on the route north from Alexandria along the coast of Palestine and Syria. As the voyage of Constantine the Jew shows, Attaleia was the natural outlet for travellers and goods from southern Anatolia.

It is, therefore, possible that Cyprus, although experiencing the political and economic ebbs and flows of the two empires, retained a kind of longue durée from the late seventh to the late tenth century, which partially bypassed the perceived barrier between the first and the second trade cycles as sketched by Wickham. ${ }^{43}$ What I mean is that Cyprus was strategically and politically a convenient middle ground at the edge of the rich Levantine regions. In particular Cyprus was in a position to intercept the trickle of regional wealth that reached the Mediterranean from Egypt, Syria, and Palestine, while at the same time remaining part of the economic dynamics of the Byzantine hinterland and at the end of the west-east trunk route. This situation seems to have lasted, though of course morphing into slightly different forms to adapt to current political and economic situations, from the late seventh century until well after the return of the island to full Byzantine control.

Indeed, the building activity of the ninth century (a continuation of the diverse styles and architecture of the eighth century) is matched by traces of urban resilience at elite and even sub-elite levels. The continued existence of this wealth supported the activity of ateliers and workshops, such as those at PolisArsinoe and Paphos-Saranda Kolones, and is likely responsible for evidence of continued local production. The role of the clergy and state administrators, as indicated by lead seals, also points to the economic resilience of the island. After all, as Wickham concludes: "the motors for internal development inside regions [were] always two: strength of the ... fiscal network and aristocratic demand. The complexity of the economic system depended on the wealth of the ruling classes". ${ }^{44}$ Moreover, Cyprus benefited from its fertile and productive hinterland and its strategic position "betwixt the Greeks and the Saracens", prompting a peculiar political status and transformation into a convenient middle ground whose stable existence continued well after the so-called Byzantine Reconquista. ${ }^{45}$ This is neither to exalt (à la Malamut) the supposed marginality of the island owing to its rural economy and inherent conservatism nor to indulge the idea of an impoverished economy dominated by the local church. ${ }^{46}$ Rather it delves into the possibility that a more fragmented Mediterranean system of exchange still could preserve spaces of convenient interconnectivity. In other words, Cyprus exhibits an exceptional normality within the so-called insular system of the eastern Mediterranean. This allowed the island to act as a real and convenient interactive hub in social, cultural, political, and even military and religious terms within an economic space that has been shown to be far more active and developed than other 
regions of the Byzantine hinterland. This would explain why Cyprus became normalized as an integral part of the so-called great eastern Mediterranean network of the second trade cycle just before the Crusades. But more importantly this would also explain the unique nature of Cyprus as an eastern Mediterranean middle ground even after the transition from Late Antiquity to the early Middle Ages. As White concludes:

if the middle ground as a process is quite common, yet the construction of a historical space in which the process becomes the basis of (creative) relations between distinct peoples is less common [as] there are instances where the process can be evident but the space may fail to emerge. ${ }^{47}$

Luckily, it seems that Cyprus was not one of these.

\section{Concluding remarks}

This book has discussed the inability of traditional approaches to explain the developing trajectories of an eastern Mediterranean island too often regarded as a marginal limbo dangerously teetering on the brink of two empires at loggerheads. These approaches depict a land engulfed by the dwarfed and more localized Mediterranean productive and distributive system; an island where the Arab raids and the crisis of imperial governmental structures created an administrative and political void; a demographically declining territory where the disruption of urban structures was only partially offset by ecclesiastical power; and a place constantly waiting to be returned to the Constantinopolitan realm. This vision and scholarly approach has been well summarized in a comparative perspective vis-à-vis other islands of the Byzantine Mediterranean by Malamut, for whom the absence of monumental buildings and the "rupture des échanges commerciaux" plunged even so fertile and rich an island as Cyprus into a four-century depression with a full recovery only in the twelfth century. ${ }^{48}$

This approach has been revealed to be more and more inadequate by recent archaeological study of the historical trajectories of the eastern Mediterranean basin as well as by more focused regional and subregional surveys. Using these contributions and those of others trying to assert the importance of "Hordenian-Purcellian" connectivity to overcome the problems overspecialized territories would have otherwise encountered in terms of limited growth and development, I have proposed a rather different type of analysis.

First, I have tried to move away from any interpretation solely based on a conservatism of archaeological evidence (architectural and artistic) or dwelling mainly on literary sources. Indeed, I have decided to sift through a methodologically aware examination of other types of material evidence. This has been mainly centred upon a developed analysis of imported and locally produced ceramics, and an examination of lead seals, coins (with particular regard to the pre-reform Arab-Byzantine coinage), glass, and other types of material 
evidence. In turn this analysis has been paired with a study of urban and rural settlement patterns moving away from the usual dichotomies - urban coastal vs. rural inland and abandonment vs. entrenchment. In my opinion, this methodologically profligate view has two merits. On the one hand, it has enabled a full recognition of the underdeveloped state of archaeological research in the northern portion of the island (the so-called occupied territory) too often passed over in silence when proposing an all-encompassing picture of Cyprus in the transitional period. On the other hand, and as a consequence of the former, it has allowed us to appreciate the intrinsic limits of any "definite" interpretation concerning the economic, political, and social status of Cyprus in the seventh and eighth centuries. This is especially true when - it often happened in the past - historiography has been influenced by the current partitioned status of the island and has failed to propose an objective approach to the period under consideration.

Second, my examination of the variety of material and literary sources has shed light on the economic soundness of Cyprus in the seventh, eighth, and possibly still in the early ninth centuries. This security was evidently grounded in the stability of the two main pillars sustaining economic vitality, urban life, and social sophistication: the presence of local secular elites and the fiscalbureaucratic machinery. It goes without saying that the former was often integral to the latter, together rubbing their shoulders with Constantinopolitan officials and the local clergy headed by the archbishop. At the same time, a re-examination of the ceramics continuously produced on, exported from, and imported to the island has shown that Cyprus had a key position in the commercial network at the crossroads of different regional economies, bypassing the boundaries between the Byzantine Empire and the Caliphate. The peculiar centrality of Cyprus in meshing three regional economic zones has allowed us to demonstrate that the more fragmented and locally oriented scale of economic exchange after the collapse of a unified Mediterranean system in the late sixth and early seventh century (which affected Cyprus far more than any other military expedition) should be scaled up to the persistence of spaces of connectivity and long-distance communications. As Haldon has argued convincingly, movements of bulk goods (as shown by post-globular amphorae or later CRSW) and travellers followed routes going from the Aegean and Peloponnesus to southern Asia Minor and Cyprus and from there to Egypt and North Africa, as well as the Syrian-Palestinian coast. ${ }^{49}$

If, indeed, the coupling of connectivity with economic prosperity well into the eighth century is a trait common to other Byzantine islands, in Cyprus it is the peculiarities of this interconnectivity that reveal an echoing of the concept of a unique middle ground. The presence of two balancing powers that, although both longing for a mutually desirable island, could not force the other to give up, the strategic location of Cyprus between cultures, peoples, and religions, and, finally, the process of accommodation and creation of systems of exchange between them is something completely unknown to other insular spaces of the Byzantine Mediterranean. ${ }^{50}$ As I have already surmised, 
the confrontational episodes stemming from the ebbs and flows of eastern Mediterranean history were integral to the construction of the Cypriot middle ground, and we are encouraged to reassess and reinterpret them less as stories of conquest and resistance than as parts of a narrative combining what White describes as "fragments of contact and change as glimpses of worlds in disorder and the attempts of people to reorder it through an amalgam of old and new logic". 51

Two specific consequences of this connotation of Cyprus as a Mediterranean middle ground deserve further characterization. It should come as no surprise that this process of creative, imaginary, and often improvised construction of peculiar relations across cultural and religious boundaries reflected an island locking together regional and subregional economies across the Mediterranean divide. In fact, central to the creative process of knitting ties on Cyprus, were instead the needs of the historical contingency and the mediation of conflicts by using both familiar and borrowed cultural (and even religious) forms. Such mediation immediately rested on the actions of local actors or brokers who were sometimes members of the local Byzantine elite (such as the phangoumeneis or bishops like Demetrianos), but above all merchants and Arab traders, immigrants, and administrators. As a secondary but equally important consequence to this peculiar cultural, social, and economic syncretism, was the inability on the part of any outsider to align with perceived or actual congruence. The promiscuity Saint Constantine the Jew found so ludicrous could indeed help us reinterpret the silence of the sources following the supposed neutralization of the island until the return of the Byzantine rule as a de facto mutual recognition of the equivocal, politically and socially fluid status of the island. ${ }^{52}$ In other words, the apparent silence of the sources can be viewed as a background narrative that until recently has remained beyond our range of hearing, a narrative of a transition happening at different levels, economic and otherwise.

The latter assertion enables me to move to a fourth and final point. Throughout this book I have substituted an earlier concept of uniform decline with a more complex model by asserting that societies deal with continuity or change "through the construction of adaptive strategies which have the effect of transforming and re-equipping existing social structures to deal with new realities". ${ }^{53}$ I am perfectly aware that the kind of analysis I have proposed needs further testing, which ideally should come from further archaeological excavations especially in the northern half of the island, which is today closed to scientific investigation. At this time, one can only wonder what kind of results urban excavations in places like Soloi, Lapethos, Kyrenia, Carpasia, and above all Salamis-Constantia could yield. The same question looms for rural surveys in areas such as the Galinoporni-Kaleburnu Plain and the Karpas peninsula in general. Would they further reveal a level of economic activity comparable to that of Syria-Palestine? Would they allow us to overcome the patchy and provisional knowledge of locally produced ceramics from the seventh and eighth centuries? Furthermore, would a detailed 
analysis of Cypriot ceramics produced from the 650s to circa 800 point to a hierarchy of fine, common, and coarse wares, or show continuity in complex local traditions and integration within a regional, subregional, and interregional network exchanging these goods across the Levant with common access to CRSW? Moreover, could we trace further urban clusters of commercial and economic activity similar to those discovered in the Levant and recently documented across and even beyond the Byzantine Mediterranean in places like Polis-Arsinoe, Gortyn, and Amorium? Would the Cypriot urban fabric reveal some similarities with these cities by showing that demonumentalization and abandonment of classical amenities set against substantial artisanal and retail activities, which took over the encroached public spaces and partitioned colonnades, resulted in different areas of settlement focused on new political and religious foci or ruined classic buildings? ${ }^{54}$

All these questions remain unanswered. Nevertheless, I believe the detailed analysis set out in the previous chapters allows us to identify a degree of regional complexity underpinned by the resilience of both landowning but urban-oriented secular (and partly religious) aristocracy and fiscal structures. This resilience continued in spite of the fact that geographical distance weakened the gravitational pull of Constantinople. In this regard, the above mentioned similarities with other islands of the Byzantine Mediterranean play an important role especially in light of recent archaeological syntheses like those of Zanini and Cosentino following in the footsteps of McCormick. ${ }^{55}$ Indeed, Cyprus, Sicily, Crete, the Balearics, and possibly Sardinia and Malta show comparable developments in the period under consideration in terms of political and administrative structures of power, economic endurance, and appurtenance to the Byzantine cultural sphere, suggesting the existence of a third political and economic pole between the Anatolian plateau and the Aegean Sea in the Byzantine Mediterranean. ${ }^{56}$ That pole should be regarded less as a peripheral focus than as an interconnection of different regional economies, which presupposed and maintained the wider system of interregional and intercultural communications that made possible the movement of goods, people, and information. This role was played at least until the Arab conquests of Sicily and Crete at the beginning of the ninth century, which brought about the end of more peaceable shipping along the navigable path controlled by these two great islands. ${ }^{57}$ Cyprus would have commanded the easternmost sector of the Mediterranean routes interlocking and connecting different regional economies, deriving benefit rather than harm from the rise of Islam in nearby Egypt, Syria, and Palestine.

This returns us once again to the concept of a middle ground. Indeed, it is not by chance that White turned his attention to sea and land (the two defining aspects of an island $)^{58}$ in order to find an exhaustive metaphor to describe its working mechanism. The history of intercultural relations has not usually produced complex stories. One people are the rock, the others are the sea, and history seems a constant storm. This relationship could produce but two outcomes: the sea repeatedly hits and dissolves the rock, or the sea erodes 
the rock but cannot fully absorb its battered remnants, which survive. White continues: "The first outcome produces stories of conquest and assimilation; the second produces stories of cultural persistence. But the tellers of such stories miss a larger process or truth. The meeting of sea and continent creates as well as destroys so something new can appear". ${ }^{59}$ Therefore, rather than producing a neutral and barren soil - an empty marsh defined by occupation and opposition - the equivalence of power relations both in seventh- and eighth-century Cyprus bred a fertile island of political, economic, and cultural ambiguity. In fact, if an island is the creation of the encounter between sea and continent, then it should also be regarded as an ideal cradle for new theories regarding the working of powers in intercultural situations that account not only for physical forces but also cultural and ideological ones. ${ }^{60}$

\section{Notes}

1 John Skylitzes (1973, 270); George Kedrenos (1838-1839, II, 363).

2 Papacostas (2002). 42; also Metcalf (2009), 499ff. and Dikigoropoulos (1961), 60-79.

3 Metcalf (2009), 500.

4 Browning (1977-1979), 112; also Metcalf (2009), 485.

5 For the contributions of these authors, see Chapter 2.

6 Dikigoropoulos (1961), 63.

7 Beihammer (2002), 55ff; see McCormick (2001), 967 with detailed reference to the sources mentioning the episode.

8 Nicholas Mystikos, ep. 102 (1973, 12-13).

9 Kyrris (1985), 202.

10 Malamut (1988), 63-71.

11 Papacostas (2012), 83.

12 Papacostas (2002), 43.

13 Metcalf (2009), 183, 502-3.

14 Papacostas (2012), 83

15 Veikou (2015b).

16 Roux (1998), 258.

17 Stewart (2008), 89. On the supposed transferral of relics, see Dikigoropoulos (1961), 59. In particular, one should mention the seal struck by the Cypriot Archbishop Epiphanios III, dated to $870 \mathrm{CE}$ and unearthed in Constantinople (Metcalf (2004), 84) and the letters he wrote to Patriarch Ignatios in 869/70 (Dikigoropoulos 1961, 60).

18 For Agios Barnabas, see Stewart (2008), 133-40; for the Book of Curiosities, see Chapter 3.

19 Metcalf (2009), 515.

20 N. Bakirtzis and L. Zavagno, "When a capital went missing: The changing urban and military landscape of Byzantine Cyprus", unpublished paper read at the International Workshop: "Amorium a Provincial Capital in the settings of the Byzantine Empire", Athens, 26 November 2016.

21 Molinari (2013), 107-11 with further and updated bibliography.

22 Wickham (2004), 172.

23 Molinari (2013), 172-3.

24 Walmsley (2007), 69-70.

25 Wickham (2005), 775-8.

26 Taxel (2013a), 104-5. Also Taxel (2013b).

27 Wickham (2009), 360-1. 
28 Papacostas (2002), 59-60

29 Stewart (2008), 155-6.

30 Ibid., 100.

31 Armstrong (2009), 174; also Randall (2013), 278. For GWW in Paphos, see Rosser (1985), 87.

32 Vroom (2005) and Vroom (2007).

33 Ryden (1993), 199. Also Jenkins (1949), and Efthymiades (2012).

34 al-Istakhrī (1870, 51); Ibn Hawqal (1964, 184).

35 al-Idrīsi (1970-1975, 643-4).

36 Lilie (1991) and Preiser-Kapeller (2015)

37 Lilie (1991), 50-1.

38 Preiser-Kapeller (2015), 140-6.

39 Brauer (1995), 7-13.

40 Morrisson (1998), 311-15.

41 Laiou and Morrisson (2007), 84; Jacoby (2000).

42 Laiou (2002b), p. 728.

43 Wickham (2004)

44 Ibid., 174.

45 I am obviously hinting here at the contributions of both Dikigoropoulos (1961) and Browning (1977-1979).

46 Malamut (1988), 456ff.

47 White (2006), 10

48 Malamut (1988), 456ff.

49 Haldon (2012a), 108.

50 White (2006), 8-14.

51 White (1991), 10.

52 Preiser-Kapeller (2015)

53 Walmsley (2007), 147.

54 Zavagno (2009), 235.

55 Zanini, Pergola, and Michaelides (2013a); Cosentino (2013a); and McCormick (2001), 780ff.

56 Cosentino (2013a), 72; McCormick (2001), 787.

57 McCormick (2001), 787.

58 Guarracino (2007), 40-5.

59 White (1991), xxv.

60 Deloria (2006), 22. 


\section{Bibliography}

\section{Primary sources}

Agapius of Manbij (1912), Kitāb al-'Unwan, edited by A.A. Vasiliev, in Patrologia Orientalis 8, III, pp. 397-550.

al-Balādhurī (1916), Kitāb futūḥ al-buldān [The Origins of the Islamic State], translated and edited by P.K. Hitti, 2 vols. New York: Columbia University Press.

al-Idrīsi (1970-5), Nuzhat al-Mushtāq fi-Ikthtirāq al-Āfāq, edited by E. Cerulli. Naples.

al-Istakhrī, Abu Ishák al-Fárisí (1870), Viae regnorum: descriptio ditionis Moslemicae, edited by M.J. De Goeje. Leiden: Brill.

al-Mas'ūdī (1989), The Meadows of Gold. The Abbasid [Murūj al-Dhahab wa-Ma'ādin al-Jawhar], translated and edited by P. Lunde and C. Stone. London: Kegan Paul.

al-Muqaddasī (1890), Description of Syria including Palestine by Mukaddasi, translated by G. Le Strange. New York: Houghton, Mifflin and Company.

al-Ṭabarī (1985-2000), Ta'rīkh al-rusul wa' l mulūk [The History of al-Ṭabarī], edited by E. Yar-Shater, 39 vols. Albany: Albany University Press.

Ammianus Marcellinus (1986), The Later Roman Empire (A.D. 354-378), translated by W. Hamilton, edited by A. Wallace-Hadrill. London: Penguin.

Anastasius of Sinai (2006), Anastasii Sinaitae Quaestiones et responsiones, edited by M. Richard and J. Munitiz. CCSG 59. Turnhout: Brepols.

Anastasius Bibliothecarius (1841), Anastasius Bibliothecarius. Historia Ecclesiastica sive Chronographia Reperita. Corpus scriptorum historiae Byzantinae 41. Bonn.

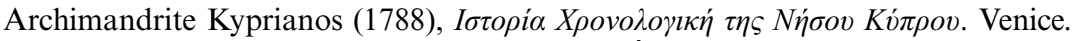

Auzépy, M.-F. (ed. and trans.) (1997), La vie d'Étienne le Diacre. Aldershot: Variorum.

Brock, S., Caner, D., and Price, R. (trans. and eds) (2010), History and Hagiography from Late Antique Sinai. Translated Texts for Historians 53. Liverpool: Liverpool University Press.

Cassius Dio (1914), Dio'sRoman History, translated by Earnest Carey, edited by H.B. Foster. London and New York: W. Heinemann.

Chabot, J.B. (ed.) (1899-1910), Chronique de Michel le Syrien, Patriarche Jacobite d'Antioche, 1166-1199 [Michael the Syrian]: Chronicon 2.470, 4 vols. Paris.

Cobham, C.D. (1908), Excerpta Cypria: Materials for a History of Cyprus. Cambridge: Cambridge University Press.

Constantine Porphyrogenitus (1993), De Administrando Imperio, edited by Gyula Moravcsik, translated by R.J.H. Jenkins. Washington, DC: Dumbarton Oaks. 
Constantinus Porphyrogenetus (1850), De Thematibus et Administrando Imperio, edited by I. Bekker. CSHB. Bonn.

Delehaye, H. (ed.) (1925), Life of Constantine the Jew, in AASS, NovemberIV. Brussels.

Delehaye, H. (1907), "Saints de Chypre", AnBoll. 26, pp. 235-237.

Delehaye, H. (1937), "La Viè Anonyme de Saint Tychon", AnBoll. 26, pp. 229-233.

Delehaye, H. (1964), "Une Vie inedite de Saint Jean l'Aumonier”, AnBoll. 82, pp. 5-64.

Dennis, G.T. (trans. and ed.) (2010), The Taktika of Leo VI. Corpus fontium historiae Byzantinae49. Washington DC: Dumbarton Oaks.

Eusebius, Historia Ecclesiastica, in PG112. Paris.

Eutychius of Alexandria (1906-9), Annales, edited by L. Cheikho. Scriptores arabici. Textus. Series Tertia, Tomus VI, CSCO50-51, 2 vols. Paris and Beirut: Carolus Possieulgue.

George of Cyprus (1890), Georgii Cypri Descriptio orbis Romani. Accedit Leonis Imperatoris Diatyposis genuina adhuc inedita, edited by H. Gelzer. Leipzig: Teubner.

George Kedrenos (1838-39), Georgius Cedrenus Historiarum Compendium, edited by L. Bekker, 2 vols. CSHB8-9. Bonn.

Gregory the Great, Super Cantica Canticorum Exposition, in PL79. Paris.

Hieroclis Synecdemus (1939), Le Synekdèmos d'Hiéroclès et l'opuscule géographique de Georges de Chypre, edited by E. Honigmann. Brussels.

Hoyland, R.G. (trans. and ed.) (2011), Theophilus of Edessa's Chronicle and the Circulation of Historical Knowledge in Late Antiquity and Early Islam. Liverpool: Liverpool University Press.

Hugeburc (1954), Vita Willibaldi1-2, in C.H. Talbot (ed.), The Anglo- Saxon Missionaries in Germany: Being the Lives of SS. Willibrord, Boniface, Sturm, Leoba and Lebuin together with the Hodoeporicon of St. Willibald and a Selection from the Correspondence of St. Boniface. London: Sheed \& Ward.

Ibn A'tham al-Kūfī (1968-1975), Kitāb al-Futūh, edited by M. Khân. Hyderabad.

Ibn al-Athīr (2008), Kitāb al-Kämil fi' l Ta'rīkh [The Chronicle of Ibn al-Athīr for the Crusading Period from al-Kamil fi'l-Ta'rikh], translated and edited by D.S. Richards. Aldershot: Ashgate.

Ibn Hawqal (1964), Configuration de la terre [Kitāb sūrat al-ard], translated and edited by J.-H. Kramers and G. Wiet, 2 vols. Beirut.

Ibn Khurdādhbeh (1967), Kitāb al-Masālik wa-al Mamālik [Le Livre de Routes et de Royaumes], translated and edited by M.J. De Goeje. Leiden: Brill.

Ibn Sallām (1988), Kitāb al-amwāl, edited by M. Harrās. Beirut: Dār al-Kutub al-Ilmīyah.

Itinerarium Antonini Placentini (1977), Un viaggio in Terra Santa del 560-70 d.C., edited by C. Milani. Milan: Mondadori.

Jeffreys, E., Jeffreys, M. and Scott, R. (trans. and eds) (1986), The Chronicle of John Malalas. Melbourne: University of Melbourne.

John, Bishop of Nikiu (1916), Chronicle, translated and edited by R.H. Charles. London: Williams \& Norgate.

John Kaminiates (1973), De expugnatione Thessalonicae, edited by G. Böhlig. Corpus fontium historiae Byzantinae. Berlin: De Gruyter.

John Moschos (2002), The Spiritual Meadow, edited by J. Wortley. Piscataway: Gorgias.

John of Ephesos (1860), Historia Ecclesiastica [Ecclesiastical History], translated and edited by R. Payne-Smith. Oxford: Oxford University Press.

John Skylitzes (1973), John Skylitzes: Synopsis Historiarum, edited by E. Thurn. Berlin and New York: De Gruyter. 
Justinian (2014), Novellae, edited by R. Schoell and W. Kroll. Corpus Iuris Civilis, Vol. 3: Novellae. Cambridge: Cambridge University Press, available athttp://droitromain.upm f-grenoble.fr/Corpus/Nov08.htm (accessed 15 January 2014).

Laterculus Veronensis (1876), Notitia Dignitatum: accedunt Notitia urbis Constantinopolitanae et laterculi provinciarum, edited by O. Seek. Berlin: Weidmannos.

Laudatio Barnabae Apostoli (1993), Hagiographica Cypria: Sancti Barnabae Laudatio auctore Alexandro Monacho et Sanctorum Bartholomaei et Barnabae vita e menologio imperiali deprompta, edited by P. Van Deun. Corpus christianorum, Series graeca26. Leuven: Peeters.

Life of Saint Auxebius (1993), Vita Sancti Auxibii, edited by J. Noret and P. Van Deun. Hagiographica Cypria. Leuven: Peeters.

Life of Saint Demetrianos (1907), H. Grégoire, "St. Démetrianos, èvêque de Chytri (île de Chypre)", BZ 16, pp. 209-312.

Life of Saint Epiphanios (1859), Epiphanii episcopi Constantiae opera, edited by L. Dindorf, Vol. 1. Leipzig.

Life of Saint John the Almsgiver (1948), Three Byzantine Saints: Contemporary Biographies of St. Daniel the Stylite, St. Theodore of Sykeon and St. John the Almsgiver, edited by E. Dawes and N.H. Baynes. London.

Life of Saint Symeon the Fool (1974), Vie de Syméon Le Fou et Vie de Jean de Chypre, edited by A.J. Festugiere and L. Ryden. Paris: Librarie Orientaliste Paul Geuthner.

Lydus (1983), De Magistratibus reipublicae Romani. Ioannes Lydus [On Power of the Magistracies of Roman State], translated and edited by A. Bandy. Philadelphia: American Philosophical Society.

Malalas (1831), Chronographia, edited by L. Dindorf. CSHB15. Bonn.

Mas Latrie, L. de (1851-62), Histoire de l'île de Chypre sous le Règne des princes de la maison de Lusignan, 3 vols. Paris: Imprimerie Impériale.

Minorsky, V. (trans. and ed.) (1937), The Regions of the World [Hadūd al-'Ālam]: $A$ Persian Geography, 372 AH-982 A.D. London: Penguin.

Nicholas Mystikos (1973), Nicholas I, Patriarch of Constantinople: Letters, translated and edited by R.H.J. Jenkins and L.G. Westerink. Corpus fontium historiae Byzantinae 6. Dumbarton Oaks Texts2. Washington DC: Dumbarton Oaks.

Nikephoros (1990), Nikephoros Patriarch of Constantinople: Short History, translated and edited by C. Mango. Washington: Dumbarton Oaks.

Notitia Dignitatum or Register of Dignitaries (1900), translated and edited by W. Fairley. Translations and reprints from original sources of European History, Vol. 6.4. Philadelphia: University of Pennsylvania Press.

Orphanides, A. and Wallace, P. (eds) (1990), Sources for the History of Cyprus, 1: Greek and Roman Texts to the Third Century C.E. Albany: Albany University Press.

Pohlsander, A. (2006), Sources for the History of Cyprus, 7: Greek Texts of the Fourth to Thirteenth Centuries. Albany: Albany University Press.

Rapoport, Y. and Savage-Smith, E. (eds) (2010), The Book of Curiosities of the Sciences and Marvels for the Eyes. Oxford: Bodleian, available athttp://cosmos.bodley.ox.ac.uk/ store/Teacher_s-Pack-Inside-pages.pdf (accessed 1 June 2016).

Roberts, L. (ed.) (2000), Latin Texts from the First Century B.C. to the Seventeenth Century C.E., Vol. 8 of Sources for the History of Cyprus. Albany: Albany University Press.

Sancti Hieronymi Epistola, in PL22, p. 519.

Schaff, P. and Wace, H. (eds) (2007), Nicene and Post-Nicene Fathers, Vol. 1: Eusebius Church History, Life of Constantine the Great, Orations in Praise of Constantine. New York: T\&T Clark. 
Scholtz, B. and Rogers, B. (eds) (1970), Carolingian Chronicles: Frankish Annals and Niheard's Histories. Ann Arbor: University of Michigan Press.

Sozomen (2015), Historia Ecclesiastica. Sozomen, A History of the Church in Nine Books. Whitefish: Aeterna.

Stephen of Byzantium (2006), Stephani Byzantii Ethnica, Vol. 1: A-G, edited by M. Billerbecket al.Corpus fontium historiae Byzantinae43. 1. Berlin and New York: De Gruyter.

Theodore Lector or Anagnostes, Theodori Lectori Historia Ecclesiastica, in PG86a, pp. $165-216$.

Theodore of Paphos (1953), La Légende de St. Spyridon évêque de Trimithonte, edited by P. Van den Ven. Leuven: Peeters.

Theophanes Continuatus (1838), edited by I. Bekker. CHSB 45. Bonn.

Theophanes (1997), The Chronicles of Theophanes Confessor, translated and edited by C. Mango and R. Scott. Oxford: Clarendon.

Theophylact Simocatta (1986), "The History of" Theophylact Simocatta, translated and edited by Michael andMary Whitby. Oxford: Oxford University Press.

Thomson, R.W., Howard-Johnston, J., and Greenwood, T. (trans. and eds) (1999), The Armenian History Attributed to Sebeos (Translated Texts for Historians), 2 vols. Liverpool: Liverpool University Press.

Venantius Fortunatus (1996), Venantius Fortunatus. De Vita Sancti Martini. Ouvrès, IV, La vie de Saint Martin, translated and edited by S. Quesnel. Paris: Collection des Universités de France.

Vita Petri Atroa (1956), Vita of the Blessed Petros of Atroa, edited by V. Laurent. Subsidia Hagiographica 29. Brussels: Société des Bollandistes.

Wilkinson, J. (1977), Jerusalem Pilgrims before the Crusades. Warminster: Aris \& Philips.

\section{Secondary sources}

Abdellatif, R., Benhima, Y., D. König, and Ruchaud, E. (eds) (2012), Acteurs des transferts culturels en Méditerranée medieval. Munich: De Gruyter.

Ahrweiler, H. (1961), Byzance et la mér. Paris: Boccard.

Akyürek, E. (2006), "The Bey Daglari in the Byzantine Period: Trebenna, Neapolis and Their Territories", in K. Dörtlük (ed.), The Third Symposium on Lycia 07-10 November 2005, Antalya. Istanbul: Akmed, pp. 1-17.

Akyürek, E. (2008), "Palamutdüzü: A medieval Byzantine village settlements in the Bey Mountains", Adalya 11, pp. 295-316.

Ambraseys, N.N. (1962), "Data for investigation of seismic sea-waves in the Eastern Mediterranean”, Bulletin of the Seismological Society of America 102(5), pp. 895-913.

Amengual i Batle, J. (1991), Els orígens del cristianisme a les Balears i el seu desenvolupament fins a l'época musulmana. Palma de Mallorca: Moll Editorial.

Argoud, G., Callot, O. and Helly, B. (1980), Salamine de Chypre. XI. Une résidence byzantine "l'huilerie". Paris: Boccard.

Armstrong, P. (2006), "Rural Settlement in Lycia in the Eighth Century", in K. Dörtlük (ed.), The Third Symposium on Lycia 07-10 November 2005, Antalya. Istanbul: Akmed, pp. 19-31.

Armstrong, P. (2009), "Trade in the East Mediterranean in the 8th Century", in M.M. Mango (ed.), Byzantine Trade 4th-12th Centuries: The Archaeology of Local, Regional and International Exchange. Papers of the Thirty-Eighth Symposium of 


\section{Bibliography}

Byzantine Studies, St. John's College, University of Oxford, March 2004. Oxford: Oxford University Press, pp. 157-178.

Arthur, P. (1989), "Aspects of Byzantine economy: An evaluation of amphora evidence from Italy”, BCH Suppl. XVIII, pp. 79-93.

Arthur, P. (2007), "Pots and Boundaries: On Cultural and Economic Areas between Late Antiquity and the Early Middle Ages", in M. Bonifay and J.-C. Tréglia (eds), LRCW2. Late Roman Coarse Wares. Cooking Wares and Amphorae in the Mediterranean: Archaeology and Archaeometry, 2 vols. Oxford: Archaeopress, pp. 15-27.

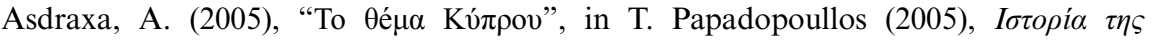

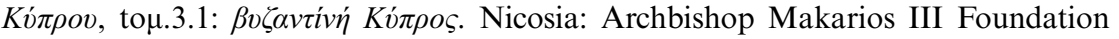
Press, pp. 199-234.

Athanassopoulos, E.F. (2010), "Landscape archaeology and the medieval countryside: Settlement and abandonment in the Nemea region", IJA 14, pp. 255-270.

Attoui, R. (ed.) (2011), When did Antiquity End? Archaeological Case Studies in Three Continents. Oxford: Archaeopress.

Aupert, P. (ed.) (2000), Guide to Amathus. Nicosia: Bank of Cyprus.

Aupert, P. (2008), “Amathonte”, Bulletin de correspondance hellénique 132, pp. 841-865.

Aupert, P. et al. (2003-4), "Amathonte", BCH128-129, pp. 1023-1077.

Avner, R. (1995), "The Heritage of Ancient Harbour Engineering in Cyprus and the Levant", in V. Karagheorghis and D. Michaelides (eds), Proceedings of the International Symposium Cyprus and the Sea. Nicosia: University of Cyprus, pp. 139-163.

Bakirtzis, C. (1995), "The Role of Cyprus in the Grain Supply of Constantinople in the Early Christian Period", in V. Karagheorgis and D. Michaelides (eds), Cyprus and the Sea: Proceedings of the International Symposium, Nicosia, 25-26 September 1993. Nicosia: University of Cyprus, pp. 247-254.

Bakirtzis, Ch. (1997), "A Sea-Route from Cyprus to the Aegean in the Early Christian Period", in Proceedings of the International Archaeological Conference Cyprus and the Aegean in Antiquity from the Prehistoric Period to the 7th Century A.D., Nicosia 8-10 December 1995. Nicosia: Cyprus Research Center, pp. 327-332.

Balandier, C. (2002a), "La defense des territoires à Chypre de l'epoque arcaïque aux invasions arabes (VIIe s. av. n.è.- VIIe s. de n.è)", Dialogues d'Histoire ancienne 28(1), pp. $175-206$.

Balandier, C. (2002b), "Les techniques de construction des fortifications Chypriotes: Héritage et influences du VIIIe s. av. J.-C. au VIIe s. apr. J.C.”, Cahier du Centre d'Études Chypriotes 31, pp. 33-44.

Balandier, C. (2003), "The defensive works of Cyprus during the late Roman and early Byzantine periods", RDAC (2003), pp. 261-272.

Baldini, I. (ed.) (2012), "Gortina, Mitropolis e il suo Episcopato nel VII e nell'VIII secolo. Ricerche Preliminari”, SAIA-Annuario della Scuola Archeologica di Atene e delle Missioni Italiane in Oriente 90, Serie III, 12.

Ballet, P. (1995), "Relations céramiques entre l'Egypte et Chypre à l'epoque grécoromaine et byzantine", in H. Meyza and Y. Mlynarczyk (eds), Hellenistic and Roman Pottery in the Eastern Mediterranean: Advances in Scientific Studies; Acts of the II Nieborów Pottery Workshop, Nieborów, 18-20 December 1993. Warsaw: Archeobooks, pp. 11-25.

Baranky, D.C. (1940-2), "The pottery from Khirbat El Mafjer", Quarterly of the Department of Antiquities in Palestine 10, pp. 65-103.

Barnes, T. (1982), The New Empire of Diocletian and Constantine. Cambridge, MA: Harvard University Press. 


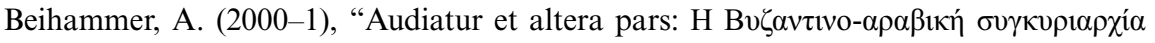

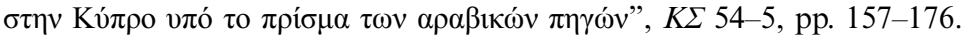

Beihammer, A. (2002), "Zypern und die byzantinisch-arabische Seepolitik vom 8. bis zum Beginn des 10. Jahrhunderts", in Y.Y. al-Hijji and V. Christides (eds), Aspects of Arab Seafaring: An Attempt to Fill in the Gaps of Maritime History. Athens: Institute for Graeco-Oriental and African Studies and Kuwait Foundation for the Advancement of Science, pp. 41-62.

Beihammer, A. (2004), "The First naval campaigns of the Arabs against Cyprus (649, 653): A reexamination of the oriental source material”, Graeco-Arabica 9-10, pp. 47-68.

Bekker-Nielsen, T. (2004), The Roads of Ancient Cyprus. Aarhus: Museum Tusculanum.

Bonifay, M. and Tréglia, J.-C. (eds) (2007), LRCW2. Late Roman Coarse Wares. Cooking Wares and Amphorae in the Mediterranean: Archaeology and Archaeometry, 2 vols. Oxford: Archaeopress.

Borrut, A. (2001), “Architecture des espaces portuaires et réseaux défensif du littoral palestinien dans les source arabes (7eme- 11eme siécles)”, Archéologie Islamique 11, pp. 21-46.

Borrut, A. (2011), Entre mémoire et pouvoir. L'espace syrien sous les derniers Omeyyades et les prèmiers Abbasides (v. 72-193/692-809). Leiden: Brill.

Bosworth, C.E. (1997), "al-Sham", in C.E. Bosworth, E. van Donzel, W.P. Heinrichs, and G. Lecomte (eds), Encyclopedia of Islam, 2nd edition (12 vols). Leiden: Brill, Vol. 9, pp. 261-298.

Bowersock, G. (2000), The International Role of Late Antique Cyprus (Annual lecture on the history and archaeology of Cyprus). Nicosia: Bank of Cyprus.

Brandes, W. (2002), Finanzverwaltung in Krisenzeiten: Untersuchungen zur byzantinischen Administration im 6.-9. Jahrhundert. Frankfurt: MPG.

Brauer, R. (1995), "Boundaries and frontier in medieval Muslim geography", Transactions of the American Philosophical Society 85(6), pp. 1-73.

Brown, H. (2007), "Islamic Coins", in A.H.S. Megaw (ed.), Kourion: Excavations in the Episcopal Precinct. Washington, DC: Dumbarton Oaks, pp. 422-423.

Brown, P. (2012), Through the Eye of a Needle. Princeton: Princeton University Press. Brown, T. (1975), "Byzantine Malta: A Discussion on the Sources", in A. Luttrel (ed.), Medieval Malta: Studies on Malta before the knights. Rome: British School, pp. 71-87.

Brown, R.B. and KreiserJr., L. (2007), The Detective a Historian: History and Art in Historical Crime Fiction. Cambridge: Cambridge University Press.

Browning, R. (1977-9), "Byzantium and the Islam in Cyprus in the early Middle Ages”, EKEE 19, pp. 101-116.

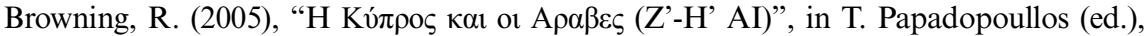

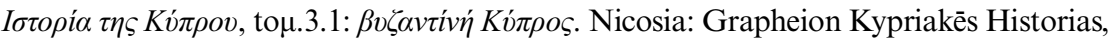
pp. 235-291.

Brubaker, L. (2012), Inventing Byzantine Iconoclasm. Studies in Early Medieval History. Bristol: Bristol Classical Press.

Brubaker, L. and Haldon, J. (2007), Byzantium in the Iconoclast Era, 1: Sources. Cambridge: Cambridge University Press.

Brubaker, L. and Haldon, J. (2011), Byzantium in the Iconoclast Era, c. 680-850: A History. Cambridge: Cambridge University Press.

Bruno, B. (2009), Roman and Byzantine Malta: Trade and Economy. La Valletta: Midsea Books. 
Bruno, B. and Cutajar, N. (2013), "Imported Amphoras as Indicators of Economic Activity in Early Medieval Malta", in E. Zanini, P. Pergola, and D. Michaelidis (eds), The Insular System of Byzantine Mediterranean: Archaeology and History. Oxford: Archaeopress, pp. 15-29.

Bryer, A.A.M. and Gheorghallides, G.S. (eds) (1993), The Sweet Land of Cyprus. Papers Given at the Twenty-Fifth Jubilee Spring Symposium of Byzantine Studies, Birmingham, March 1991. Nicosia: Cyprus Research Center.

Bury, J. (1923), "The provincial list of Verona”, JRS 13, pp. 127-151.

Callot, O. (2004), Salamine de Chypre, XVI, Les monnaies. Fouilles de la ville, 1964-1974. Paris: Boccard.

Cameron, A. (1992), "Cyprus at the time of the Arab conquest", Cyprus Historical Review 1, pp. 27-49.

Cameron, A. and Conrad, L.J. (eds) (1992), Byzantium and the Early Islamic Near East, 1: Problems in the Literary Source Material. Princeton: Princeton University Press.

Caraher, W. and Papalexandrou, A. (2012), "Arsinoe in Late Antiquity and the Middle Ages", in W. Childs, J.M. Padgett, and J.S. Smith (eds) (2012), City of Gold: The Archaeology of Polis Chrysochous, Cyprus. Princeton: Princeton University Press, pp. 262-282.

Caraher, W., Moore, R.S., Olson, B.R., and Papalexandrou, A. (2013), "The South Basilica at Arsinoe (Polis-Tes-Chrysochou): Change and Innovation in an Early Christian Basilica on Cyprus", in M. Parani and D. Michaelides (eds), The Archaeology of Late Antique and Byzantine Cyprus (4th-12th Centuries AD): Conference in Honour of Athanasios Papageorghiou. Cahiers du Centre d'Études Chypriotes, 43, pp. 79-92.

Caraher, W., Moore, R.S. and Pettigrew, D. (2010), "Trade and exchange in the eastern Mediterranean", Bollettino di Archeologia On Line 1, pp. 23-26.

Carandini, A. (2010), Storie dalla terra. Manuale di Scavo Archeologico. Turin: Einaudi.

Catling, H.W. (1972), "An early Byzantine pottery factory at Dhiorios in Cyprus", Levant 4(1), pp. 1-82.

Catling, H.W. (1982), "The ancient topography of the Yalias valley", RDAC (1982), pp. $227-236$.

Catling, H.W. and Dikigoropoulos, A.I. (1970), "The Kornos Cave: An early Byzantine site in Cyprus", Levant 2(1), pp. 37-62.

Cau Ontiveros, M.A. and Mas Florit, C. (2013), "The Early Byzantine Period in the Balearic Islands", in E. Zanini, P. Pergola, and D. Michaelidis (eds), The Insular System of Byzantine Mediterranean: Archaeology and History. Oxford: Archaeopress, pp. $31-46$.

Chavaud, B. and Yon, M. (1978), Salamine de Chypre 10. Testimonia Salamina. Paris: Boccard.

Cheynet, J.C. (2008), La Société Byzantine: l'apport des sceaux (Bilan de Recherches 3/ 1and 3/2). Paris: Association des amis du centre d'histoire et civilization de Byzance.

Cheynet, J.C. and Caseau, B. (2012), "Sealing Practices in Byzantine Administration", in I. Regulsky, K. Duistermmat, and P. Verkinderen (eds), Seals and Sealing Practices in the Near East: Developments in Administration and Magic from Prehistory to the Islamic Period. Proceedings of an International Workshop at the Netherlands-Flemish Institute in Cairo on December 2-3, 2009. Leuven: Peeters, pp. 133-149.

Childs, W., Padgett, J.M., and Smith, J.S. (eds) (2012), City of Gold: The Archaeology of Polis Chrysochous, Cyprus. Princeton: Princeton University Press. 
Christides, V. (2006), The Image of Cyprus in the Arabic Sources. Nicosia: Cyprus Research Center.

Christie, A. (1954), The Mousetrap. New York: Samuel French.

Christou, D. (1996), "Chronique des fouilles et découvertes archéologiques à Chypre en 1995", $B C H 120(2)$, pp. 1051-1100.

Christou, D. (1997), "Chronique des fouilles et découvertes archéologiques à Chypre en 1996", BCH 121(2), pp. 433-552.

Chrysos, E. (1993), "Cyprus in Early Byzantine Times", in A.A.M. Bryer and G.S. Gheorghallides (eds), The Sweet Land of Cyprus. Papers Given at the Twenty-Fifth Jubilee Spring Symposium of Byzantine Studies, Birmingham, March 1991. Nicosia: Cyprus Research Center, pp. 3-14.

Cobham, C.D. (1897), "The story of Umm Haram", JRAS 24, pp. 81-101.

Conrad, L.I. (1992), "The Conquest of Arwâd: A Source Critical Study of the Historiography of the Early Medieval East", in A. Cameron and L.J. Conrad (eds), Byzantium and the Early Islamic Near East, 1: Problems in the Literary Source Material. Princeton: Princeton University Press, pp. 317-401.

Conrad, L.I. (1996), "The Arabs and the Colossus", JRAS, III series, 6(2), pp. 165-187.

Cosentino, S. (2008), "Constans II and the Byzantine navy", BZ 100(2), pp. 577-603.

Cosentino, S. (2011), "Economia e Fiscalità nei 'secoli oscuri': in merito alla questione dei kommerkiarioi”, in R. Gentile Messina (ed.), Bisanzio e le Periferie dell'Impero. Acireale and Rome: Bonanno, pp. 59-72.

Cosentino, S. (2013a), "Mentality, Technology and Commerce: Shipping amongst Mediterranean Islands in Late Antiquity and Beyond", in E. Zanini, P. Pergola, and D. Michaelidis (eds), The Insular System of Byzantine Mediterranean: Archaeology and History. Oxford: Archaeopress, pp. 65-76.

Cosentino, S. (2013b), "A Longer Antiquity? Cyprus, Insularity and the Economic Transition", in M. Parani and D. Michaelides (eds), The Archaeology of Late Antique and Byzantine Cyprus (4th-12th centuries AD): Conference in Honour of Athanasios Papageorghiou. Cahiers du Centre d'Études Chypriotes, 43, pp. 93-103.

Coulton, J.J. (2012), "Late Roman and Byzantine Balboura", in J.J. Coulton (ed.), The Balboura Survey and Settlement in Highland South-West Anatolia. Ankara: BIAA, pp. $163-185$.

Coureas, N. (2013), "Cultural Brokers at the Court of Lusignan in Cyprus", in M. Höh, N. Jaspert, and J.R. Oesterle (eds), in Cultural Brokers at Mediterranean Courts in the Middle Ages. Paderborn: Wilhelm Fink GmbH, pp. 231-244.

Crostini, B. and La Porta, S. (eds) (2013), Negotiating Co-Existence: Communities, Culture and Convivencia in Byzantine Society. Trier: Wissenschaftlicher Verlag Trier.

Ćurčić, S. (1999), "Byzantine Architecture on Cyprus: An Introduction to the Problem of the Genesis of a Regional Style", in N.P. Sevčenko and C. Moss (eds), Medieval Cyprus: Studies in Art, Architecture and History in Memory of Doula Mouriki. Princeton: Princeton University Press, pp. 71-94.

Ćurčić, S. (2000), Byzantine Architecture on Cyprus: Provincial or Regional? Nicosia: Bank of Cyprus.

Curta, F. (2002), "Quaestura exercitus. The evidence of lead seals", $A B z F$, N.s.1, pp. 9-26.

Curta, F. (2006), Southeastern Europe in the Middle Ages, 500-1250. Cambridge: Cambridge University Press.

Curta, F. (2011), The Edinburgh History of the Greeks, C. 500 to 1050: The Early Middle Ages. Edinburgh: Edinburgh University Press. 
Dagron, G. (1985), "Un tarif de sportules à payer aux curiosi du port de Séleucie de Piérie (VIe siècle)", TM 9, pp. 435-455.

Dagron, G. (2002), "The Urban Economy: Sixth to Twelfth Century", in A. Laiou (ed.), (2002), The Economic History of Byzantium, 3 vols. Washington, DC: Dumbarton Oaks, Vol. 2, pp. 393-461.

Dark, K. (2001), Byzantine Pottery. Briscombe Port: Tempus.

Daszewski, W.A. and Michaelides, D. (eds) (1988), Mosaic Floors in Cyprus (Biblioteca di Felix Ravenna 3). Ravenna: Mario Lapucci, Edizioni del Girasole.

Davis, T.W. and Stewart, C.A. (2014), "A Brief History of Byzantine Archaeology in Cyprus", in C.A. Stewart, T.W. Davis, and A.-M. Weyl Carr (eds), Cyprus and the Balance of Empires: Art and Archaeology from Justinian I to the Coeur de Lion. Boston: CAARI, pp. 17-28.

De Angelis, F. (2012), “Archaeology in Sicily 2006-2010”, Archaeological Reports 58, pp. $123-195$.

Des Gagniers, J. and Tinh, T.T. (1985), Soloi. Dix campagnes des fouilles (1964-74), Vol. 1: la Basilique. Sainte- Foy: Université Laval.

Dedeyan, G. (1995), "Les Arméniens á Chypre de la fin du XI siècle au début du XIII siècle", in Les Lusignans et l'outre-Mer (Actes du Colloque Poitiers-Lusignan, 20-24 Octobre 1993). Poitiers: Université de Poitiers, pp.122-131.

Deloria, P. (2006), "What is the middle ground anyway?" The William and Mary Quarterly, Third Series, 63(2), pp. 15-22.

Delvoye, C. (1980), "La place des grandes basiliques de Salamine de Chypre dans l'architecture paléochrétienne", in M. Yon (ed.), Salamine de Chypre. Histoire et archéologie. État des recherches (Colloques Internationaux du CNRS578). Paris: CNRS, pp. 313-328.

Demesticha, S. (2013), “Amphora Typologies, Distribution and Trade Pattern: The Case of Cypriot LR1 Amphorae", in M. Lawall and J. Lund (eds), Transport Amphorae and Trade of Cyprus. Aahrus: Gosta Embom, pp. 169-178.

Demesticha, S. (2014), "Late Roman Amphora Typology in Context", in N. PoulouPapadimitriou, E. Nodarou, and V. Kilikoglu (eds), Late Roman and Coarse Wares, Cooking wares and Amphorae in the Mediterranean. Archaeology and Archeometry. The Mediterranean a market without frontiers. Oxford: Archaeopress, pp. 599-606.

Demesticha, S. and Michaelides, D. (2001), "The Excavation of a Late Roman 1 Amphora Kiln in Paphos", in E. Villeneuve and P. Watson (eds), La Céramique Byzantine et Proto-Islamique en Syrie-Jordanie (IVe-VIIIe siècles apr. J.-C.): Actes du colloque tenu à Amman les 3, 4, 5 décembre 1994. Beirut: Institut français d'archéologie du Proche-Orient, pp. 289-296.

Déroche, V. (1995), Études sur Léontios de Néapolis. Uppsala: Uppsala Universitet.

Diederichs, E. (ed.) (1980), Salamine de Chypre. Histoire et Archéologie. État des recherches. Lyon 13-17 mars 1978. Paris: Boccard.

Dikigoropoulos, A.I. (1958), “The political status of Cyprus, C.E. 648-965”, RDAC (1958), pp. 94-114.

Dikigoropoulos, A.I. (1961), "Betwixt the Greeks and the Saracens, C.E. 647-965", unpublished DPhil dissertation, University of Oxford.

Dikigoropoulos, A.I. (1965-6), "The Church of Cyprus during the period of the Arab Wars, C.E. 649-965", The Greek Orthodox Theological Review 11, pp. 237-279.

Ditten, H. (1993), Ethnische Verschiebungen zwischen der Balkanhalbinsel und Kleinasien vom Ende des 6. bis zur zweiten Hälfte des 9. Jahrhunderts. Berlin: DeGruyter.

Dodd, A. (1961), Byzantine Silver Stamps. Washington, DC: Dumbarton Oaks. 
Donner, F. (1981), The Early Islamic Conquests. Princeton: Princeton University Press.

Donner, F. (2012), Muhammad and the Believers: At the Origins of Islam. London: Belknap Press.

Downey, G. (1958), "The claim of Antioch to ecclesiastical jurisdiction over Cyprus", Proceedings of the American Philosophical Society 102(3), pp. 224-228.

Du Plat Taylor, J. and Megaw, A.H.S. (1981), "Excavations at Ayos Philon in the ancient Carpasia, the early Christian buildings", RDAC (1981), pp. 209-250.

Dunn, A. (1993), "The Kommerkiarion, the Apotheke, the Dromos, the Vardarios and the West", BMGS 17, pp. 3-24.

Dunn, A. (1998), "Heraclius' 'Reconstruction of Cities' and their sixth-century Balkan antecedents", in Acta XIII Congressus Internationalis Archaeologiae Christianae, Pars 2. Studi di Antichità Cristiana pubblicata a cura del Pontificio Istituto di Archeologa Cristiana, 54. Città del Vaticano, pp. 795-804.

Dunn, A. (2007), "Lead Seal of Damianos, Archbishop of Cyprus", in A.H.S. Megaw (ed.), Kourion: Excavations in the Episcopal Precinct. Washington, DC: Dumbarton Oaks, pp. 539-540.

Durand, J. and Giovannoni, D. (eds) (2012), Chypre entre Byzance et l'Occident (IVeme-XVIeme) siècle. Catalogue du l' exposition organisée par le musée du Louvre et le Département des Antiquités de Chypre à l'occasion de la Présidence Chypriote du Conseil de l'Union européenne. Paris: SOMOGY.

Efthymiades, S. (ed.) (2011a), The Ashgate Research Companion in Byzantine Hagiography, Vol. 1: Periods and Places. Farnham and Burlington: Ashgate.

Efthymiades, S. (2011b), "Hagiography from the "Dark Ages" to the Age of Symeon Metaphrastes (eighth-tenth century)", in S. Efthymiades (ed.), The Ashgate Research Companion in Byzantine Hagiography, Vol. 1: Periods and Places. Farnham and Burlington: Ashgate, pp. 95-141.

Efthymiades, S. (2012), "Re-reading the 'Life of Saint Demetrianos of Chytri/ Kytherea' (BHG 246)", Rivista di Studi Bizantini e Neoellenici 49, pp. 263-274.

Efthymiades, S. and Déroche, V. (2012), "Greek Hagiography in Late Antiquity", in S. Efthymiadis (ed.), The Ashgate Research Companion to Byzantine Hagiography. Farham-Burlington: Ashgate, pp. 35-94.

Engels, D., Geis, L., and Leu, M. (eds) (2010), Zwischen Ideal und Wirklichkeit. Herrschaft auf Sizilien von der Antike bis zum Spätmittelalter. Stuttgart: Franz Steiner Verlag.

Englezakis, B. (ed.) (1995a), Studies on the History of the Church of Cyprus, 4th-20th Centuries. Aldershot: Ashgate.

Englezakis, B. (1995b), "Epiphanius of Salamis, the Father of the Cypriot Autocephaly", in B. Englezakis (ed.), Studies on the History of the Church of Cyprus, 4th-20th Centuries. Aldershot: Ashgate, pp. 29-41.

Englezakis, B. (2010), Cyprus, Nea Justinianoupolis. Nicosia: Bank of Cyprus Cultural Foundation.

Farace, V. (2015), "Agia Varvara in Cipro e le relazioni artistiche fra Bisanzio e l'Islam fra ottavo e nono secolo", unpublished MA thesis, University of Venice.

Fejfer, J. (ed.) (1995), Ancient Akamas: Settlement and Environment. Aarhus: Aarhus Universitetsforlag.

Fejfer, J. and Hayes, P.P. (1995), "Ancient Akamas and the Abandonment of Sites in Seventh-Century Cyprus", in P.W. Wallace (ed.), Visitors, Immigrants and Invaders in Cyprus. Albany: Albany University Press, pp. 62-69. 


\section{Bibliography}

Fejfer, J. and Mathiesen, P. (1992), "A Late Roman/Early Byzantine Site in the Akamas", in P. Åström (ed.), Acta Cypria: Acts of an International Congress on Cypriote Archaeology held in Göteborg on 22-24 August 1991. Part 2. Gothenburg: Åströms Förlag, pp. 67-83.

Fernández Delgado, A., Martinez Jiménez, J., and Tejerizo Garcia, C. (2013), “Old and New Elites in the Visigothic kingdom (AD 550-565)", in E.M. Van der Wilt, J. Martinez Jiménez andG. Petruccioli (eds), Tough Times: The Archaeology of Crisis and Recovery. Proceedings of the Graduate Archaeology at Oxford Conferences in 2012 and 2011. Oxford: Archaeopress, pp. 161-170.

Flemming, N. (1974), "Report of preliminary underwater investigations at Salamis Cyprus", $R D A C$ (1974), pp. 163-174.

Flourentzos, P. (1996), Excavations in the Kouris Valley, Vol. 2: The Basilica of Alassa. Nicosia: Cyprus Research Center.

Flourentzos, P. (2002), "A rare magic bronze pendant from Amathous", $R D A C$ (2002), pp. 365-367.

Foss, C. (2003), "The Persians in the Roman near east", Journal of the Royal Asiatic Society 13(2), pp. 149-170.

Foss, C. (2008), Arab-Byzantine Coins: An Introduction, with a Catalogue of the Dumbarton Oaks Collection. Washington, DC: Dumbarton Oaks.

Foss, C. (2010), "Mu'âwiya's State", in J. Haldon (ed.), Money, Power and Politics in Early Islamic Syria: A Review of Current Debates. Burlington: Ashgate, pp. 75-96.

Foss, C. and Winfield, D. (1986), Byzantine Fortifications: An Introduction. Pretoria: USA Press.

Francois, V. and Spieser, J.-M. (2002), "Pottery and Glass in Byzantium", in A. Laiou (ed.), (2002), The Economic History of Byzantium, 3 vols. Washington, DC: Dumbarton Oaks, pp. 593-607.

Gelichi, S. et al. (2006), "Comacchio fra IV e X secolo: Territorio, abitato e infrastrutture", in R. Francovich and M. Valenti, IV Congresso Nazionale di Archeologia Medievale. Florence: Insegna del Giglio, pp. 19-48.

Gelichi, S. (2012), "Local and Interregional Exchange in the Lower Po Valley, EighthNinth Centuries", in C. Morrisson (ed.), Trade and Markets in Byzantium (Dumbarton Oaks Byzantine Symposia and Colloquia). Washington, DC: Dumbarton Oaks, pp. 219-235.

Giardina, A. (2007), "Perspectives on Roman History", in C. Wickham (ed.), Marxist History-Writing for the Twenty-First Century (British Academy Occasional Papers). London: British Academy, pp. 15-31.

Given, M. and Knapp, B. (eds) (2003), The Sydney Cyprus Survey Project: Social Approaches to Regional Archaeological Survey. Los Angeles: The Coetsen Institute of Archaeology.

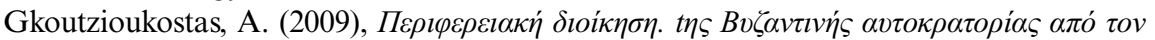

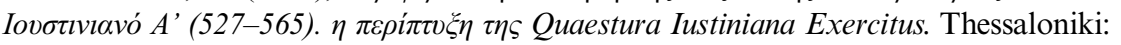
Ekdosis Banias.

Goodwin, T. (2005), Arab-Byzantine Coinage. London: Khalili Institute.

Goodwin, T. and Philips, M. (1997), "A seventh-century Syrian hoard of Byzantine and imitative copper coins", $N C$ 157, pp. 61-87.

Green, J. (1973), “An Underwater Archaeological Survey of Cape Andreas (Cyprus) 1969-1970: A Preliminary Report”, in D. Blackman (ed.), Marine Archaeology. Bristol: Colston Papers, pp. 141-179. 
Gregory, T.E. (1987), "Circulation of Byzantine and Medieval Pottery in Southwestern Cyprus", in D.W. Rupp (ed.), Western Cyprus: Connections. An Archaeological Symposium held at Brock University, St. Cahterines, Ontario, Canada. Gothenburg: Åströms Förlag, pp. 198-199.

Gregory, T.E. (2003), "The Byzantine Problem”, in M. Given and B. Knapp (eds), The Sydney Cyprus Survey Project: Social Approaches to Regional Archaeological Survey. Los Angeles: The Coetsen Institute of Archaeology, pp. 283-284.

Gregory, T.E. (2005), A History of Byzantium. Oxford: Oxford University Press.

Griffith, S. (2008), The Church in the Shadow of the Mosque: Christians and Muslims in the World of Islam. Princeton: Princeton University Press.

Guarracino, S. (2007), Mediterraneo: Immagini, Storie e Teorie da Omero a Braudel. Rome: Mondadori.

Guillou, A. (1988), "La Géographie historique de l'ile de Chypre pendant la période byzantine (IVe-XIIe s.)”, EB. Cahiers Pierre Belon. Matériaux pour une historie de Chypre (IVe-XXe s.), pp. 9-32.

Gunnis, R. (1936), Historic Cyprus: A Guide to its Towns and Villages, Monasteries and Castles. London: Methuen.

Hackett, J.A. (1901), History of the Orthodox Church of Cyprus. From the Coming of the Apostles Paul and Barnabas to the Commencement of the British Occupation (A. D. 45- A.D. 1878). Together with Some Account of Latin and Other Churches Existing on the Island. London: Methuen.

Hadjisavvas, S. (1992), Olive Oil Processing in Cyprus: From the Bronze Age to the Byzantine Period. Gothenburg: Åströms Förlag.

Hadjisavvas, S. (1998), "Chronique des fouilles et découvertes archéologiques à Chypre en 1997”, BCH 122(2), pp. 663-703.

Hadjisavvas, S. (2010), Cyprus: Crossroads of Civilizations. Nicosia: The Government of the Republic of Cyprus.

Hadjisavvas, S. (2015), "Protecting the cultural heritage of Cyprus: International laws and concerns", JEMAHS 3(2), pp. 128-140.

Haldon, J. (1990), Byzantium in the Seventh Century: The Transformation of a Culture. Cambridge: Cambridge University Press.

Haldon, J. (1992), "The Works of Anastasius of Sinai: A Key Source for the History of Seventh-Century East Mediterranean Society and Belief", in A. Cameron and L.J. Conrad (eds), Byzantium and the Early Islamic Near East, 1: Problems in the Literary Source Material. Princeton: Princeton University Press, pp. 107-147.

Haldon, J. (1999), Warfare, State and Society in the Byzantine World (565-1204 C.E.). London: Routledge.

Haldon, J. (ed.) (2010a), The Palgrave Atlas of Byzantine History. New York: Palgrave.

Haldon, J. (ed.) (2010b), Money, Power and Politics in early Islamic Syria: A Review of Current Debates. Burlington: Ashgate.

Haldon, J. (2010c), "Greater Syria in the Seventh Century: Context and Background", in J. Haldon (ed.), Money, Power and Politics in early Islamic Syria: A Review of Current Debates. Burlington: Ashgate, pp. 1-20.

Haldon, J. (2012a), "Commerce and Exchange in the Seventh and Eighth Centuries: Regional Trade and the Movement of Goods", in C. Morrisson (ed.), Trade and Markets in Byzantium (Dumbarton Oaks Byzantine Symposia and Colloquia). Washington, DC: Dumbarton Oaks, pp. 99-124.

Haldon, J. (2012b), "Resources, Markets and State: The Case of Byzantium", available at www.econ.yale.edu/ egcenter/haldon-2012.pdf (accessed 18 July 2016). 
Haldon, J. (2014), A Critical Commentary on the Taktika of Leo VI. Washington DC: Dumbarton Oaks.

Haldon, J. (2016), The Empire that Would Not Die: The Paradox of Eastern Roman Survival. Cambridge, MA: Harvard University Press.

Haldon, J. and Kennedy, H. (1980), "The Arab-Byzantine Frontier in the Eighth and Ninth Centuries: Military Organization and Society in the Borderlands", Recueil des Travaux de l'Institut d'Etudes Byzantins (Belgrade) 19, pp. 79-116.

Halkin, F. (1945), "La Vision de Kaioumos et le sort éternal de Philentolos Olympiou", $A B$ 62, pp. 56-64.

Halkin, F. (1973), Études d'épigraphie grecque et d'hagiographie byzantine. London: Variorum.

Hansen, I.L. and Wickham, C. (eds) (2000), The Long Eighth Century: Production, Distribution and Demand. Leiden: Brill.

Hardy, S.A. (2011), "Interrogating Archaeological Ethics in Conflict Zones: Cultural Heritage Work in Cyprus", unpublished PhD dissertation, University of Sussex.

Harpster, M. (2008), "Maritime archaeology and maritime heritage protection in the disputed territory of Northern Cyprus", Journal of Maritime Archaeology 3, pp. 3-13.

Hausmair, B. (2013), "The Impact of Late Antique Crises in Noricum Ripense: Depopulation vs. Invisible People”, in E.M. Van der Wilt, J. Martinez Jiménez andG. Petruccioli (eds), Tough Times: The Archaeology of Crisis and Recovery. Proceedings of the Graduate Archaeology at Oxford Conferences in 2012 and 2011. Oxford: Archaeopress, pp. 149-160.

Hayes, J. (1980), "Problèmes de la céramique des VIIème-IXème siècles a Salamine de Chypre", in E. Diederichs (ed.), Salamine de Chypre. Histoire et Archéologie. État des recherches. Lyon 13-17 mars 1978. Paris: Boccard, pp. 375-387.

Hayes, J. (1991), Paphos III: Hellenistic and Roman Pottery. Nicosia: Department of Antiquities.

Hayes, J. (2007), "Pottery", in A.H.S. Megaw (ed.), Kourion: Excavations in the Episcopal Precinct. Washington, DC: Dumbarton Oaks, pp. 435-475.

Heilo, O. (2016), Eastern Rome and the Rise of Islam. London and New York: Routledge.

Hendy, M. (1985), Studies in the Byzantine Monetary Economy c. 300-1450. Cambridge: Cambridge University Press.

Hendy, M. (2007), "Late Roman and Early Byzantine Coins", in A.H.S. Megaw (ed.), Kourion: Excavations in the Episcopal Precinct. Washington, DC: Dumbarton Oaks, p. $401-425$.

Herrin, J. (2009), Byzantium: The Surprising Life of a Medieval Empire. Princeton: Princeton University Press.

Herrin, J. (2013), Margins and Metropolis: Authority across the Byzantine Empire. Princeton: Princeton University Press.

Hill, G. (1940-52), History of Cyprus, 4 vols. Cambridge: Cambridge University Press.

Hinderaker, E. (2004), "Translation and Cultural Brokerage", in P.J. Deloria and N. Salisbury (eds), A Companion to American Indian History. Oxford: Oxford University Press.

Hirschfeld, Y. (1997), "Farms and villages in Byzantine Syria", DOP 51, pp. 33-71.

Hodges, R. (1989), Dark Ages Economics: The Origins of Towns and Trade AD 600-1000. Bristol: Duckworth.

Hodges, R. and Whitehouse, D. (1983), Mohammed, Charlemagne, and the Origins of Europe: Archaeology and the Pirenne Thesis. Ithaca: Cornell University Press. 
Holum, K.G. (2011), "Caesarea Palaestinae. A Paradigmatic Transition”, in K. Holum and H. Lapin (eds), Shaping the Middle East: Jews, Christians and Muslims in an Age of Transition, 400-800. Vol. 20 of Studies and Texts in Jewish History and Culture. Bethesda: University of Maryland Press, pp. 11-32.

Holum, K.G. and Lapin, H. (eds) (2011), Shaping the Middle East: Jews, Christians and Muslims in an Age of Transition, 400-800. Vol. 20 of Studies and Texts in Jewish History and Culture. Bethesda: University of Maryland Press.

Horden, P. and Purcell, W. (2000), The Corrupting Sea: A Study in Mediterranean History. Oxford: Oxford University Press.

Howard-Johnston, J. (2006), East Rome, Sassanian Persia and the End of Antiquity: Historiographical and Historical Studies. Aldershot: Variorum.

Howard-Johnston, J. (2010), Witnesses to a World Crisis: Historians and Histories of the Middle East in the Seventh Century. Oxford: Oxford University Press.

Ilisch, L. (2010), "Abd al-Malik's Monetary Reform in Copper and the Failure of Centralization", in J. Haldon (ed.), Money, Power and Politics in Early Islamic Syria: A Review of Current Debates. Burlington: Ashgate, pp. 125-146.

Ivison, E.A. (2007), "Amorium in the Byzantine Dark Ages (Seventh to Ninth Centuries)", in J. Henning (ed.), Post-Roman Towns, Trade and Settlement in Europe and Byzantium, Vol. 2: Byzantium, Pliska, and the Balkans. Berlin and New York: De Gruyter, pp. 25-59.

Jackson, M., Zelle, M., Vandeput, L., and Köse, V. (2012), "Primary evidence for late Roman D production in southern Asia Minor: A challenge to 'Cypriot red slip ware"”, $A S$ 62, pp. 89-114.

Jacobsen, K.W. (2004), "Regional Distribution of Transport Amphorae in Cyprus in the Late Roman Period", in J. Eiring and J. Lund (eds), Transport Amphorae and Trade in the Eastern Mediterranean: Acts of the International Colloquium at the Danish Institute at Athens, September 26-29, 2002. Athens: Danish Institute, pp. 143-149.

Jacoby, D. (2000), "Byzantine trade with Egypt from the mid-tenth century to the Fourth Crusade", Thesaurismata 30, pp. 25-77.

Jeffreys, E. and Pryor, J.H. (2006), The Age of Dromon: The Byzantine Navy ca. 500-1204. Leiden: Brill.

Jenkins, R.J.H. (1949), "The mission of St. Demetrianus to Bagdad", Annuaire del'Institut de Philologie et d'Histoire Orientales et Slaves 9, pp. 267-273.

Jenkins, R.J.H. (1953), "Cyprus between Byzantium and Islam, A.D. 688-965", in G.E. Mylonas, Studies Presented to D.M. Robinson. St. Louis: Eden, Vol. 2, pp. 1006-1014.

Johnson, S.F. (2006), The Life and Miracles of Saint Thekla: A Literary Study. Cambridge, MA: Harvard Press.

Kaegi, W. (1992), Byzantium and the Early Islamic Conquest. Cambridge: Cambridge University Press.

Kaegi, W. (2003), Heraclius: Emperor of Byzantium. Cambridge: Cambridge University Press.

Kaegi, W. (2010), Muslim Expansion and Byzantine Collapse in North Africa. Cambridge: Cambridge University Press.

Karageorghis, V. (1960), "Chroniques des Fouilles en 1959”, BCH 84, pp. 242-299.

Karageorghis, V. (1963), "Excavations at Salamis, 1963”, RDAC (1963), pp. 52-55.

Karageorghis, V. (1967), "Chronique des fouilles et découvertes archéologiques à Chypre en 1966”, BCH 91(1), pp. 275-370. 


\section{Bibliography}

Karageorghis, V. (1969), Salamis: Recent Discoveries in Cyprus. New York: McGraw-Hill.

Karageorghis, V. (ed.) (1985), Archaeology in Cyprus: 1960-1985. Nicosia: Leventis Foundation.

Karageorghis, V. and Maier, F. (1984), Paphos: History and Archaeology. Nicosia: Leventis Foundation.

Kenkel, F. (2007), "The Cypriot Red Ware and its Derivatives from Pednelissos in Pisidia", in B. Böhlendorf-Arslan, A. Osman Uysal, and J. Witte-Orr (eds), Byzas 7. Çanak. Late Antique and Medieval Pottery and Tiles in Mediterranean Archaeological Contexts. Proceedings of the First International Symposium on Late Antique, Byzantine, Seljuk, and Ottoman Pottery and Tiles in Archaeological Context (Çaanakkale, 1-3 June 2005). Istanbul: Ege Yayınları, pp. 131-146.

Kennedy, H. (2004), The Prophet and the Age of Caliphates: The Islamic Near East from the Sixth to the Eleventh Century. London: Routledge.

Kennedy, H. (2007a), The Great Arab Conquest: How the Spread of Islam Changed the World We Live in. Philadelphia: Da Capo Press.

Kennedy, D. (2007b), Gerasa and the Decapolis: A 'Virtual Island' in North-West Jordan. London: Duckworth.

Kennedy, H. (2010), "Syrian Elites from Byzantium to Islam: Survival or Extinction?", in J. Haldon (ed.), The Palgrave Atlas of Byzantine History. New York: Palgrave, pp. 181-198.

Ker-Lindsey, J. (2011), The Cyprus Problem: What Everyone Needs to Know? Oxford: Oxford University Press.

Koder, J. (2012), "Regional Networks in Asia Minor during the Middle Byzantine Period: Seventh to Eleventh Century", in C. Morrisson (ed.), Trade and Markets in Byzantium (Dumbarton Oaks Byzantine Symposia and Colloquia). Washington, DC: Dumbarton Oaks, pp. 147-175.

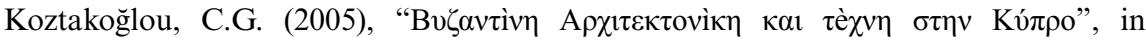

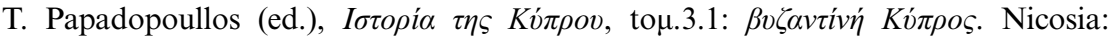
Archbishop Makarios III Foundation Press, pp. 465-788.

Kraus, P. (1962), "Djābir B. Hayyān”, in Encyclopaedia of Islam, 4 vols. Leiden: Brill, Vol. 2, pp. 357-359.

Kyrris, C.P. (1970), "Military colonies in Cyprus in the Byzantine period: Their character, purpose and extent", Byzantinoslavica 31, pp. 157-181.

Kyrris, C.P. (1984), "The nature of the Byzantine-Arab relations in Cyprus from the middle of the 7th to the middle of the 10th century AD", Graeco-Arabica 3, pp. 149-175.

Kyrris, C.P. (1985), History of Cyprus. Nicosia: Nicocles Publishing House.

Kyrris, C.P. (1997), "Cyprus, Byzantium and the Arabs from the Mid-7th to the Early 8th Century", in L. Belletto (ed.), Oriente ed Occidente fra Medioevo ed Età Moderna. Studi in onore di Geo Pistarino. Genoa: Liguori, pp. 668-691.

Laiou, A. (ed.) (2002a), The Economic History of Byzantium, 3 vols. Washington, DC: Dumbarton Oaks.

Laiou, A., (2002b), "Exchange and Trade", in A. Laiou (ed.), The Economic History of Byzantium, 3 vols. Washington, DC: Dumbarton Oaks, pp. 697-770.

Laiou, A. and Morrisson, C. (2007), The Byzantine Economy. Cambridge: Cambridge University Press.

Langdale, A. (2012), In a Contested Realm: An Illustrated Guide to the Archaeology and Historical Architecture of Northern Cyprus. Edinburgh: Grimsey Press.

Lawall, M. and Lund, J. (eds) (2013), Transport Amphorae and Trade of Cyprus. Aarhus: Gosta Embom. 
Leader, R.E. (2000), "The David Plates revisited: Transforming the secular in early Byzantium", The Art Bulletin 82(3), pp. 407-427.

Lécuyer, N.et al. (2002), "Potamia-Agios Sozomenos (Chypre): La constitution des paysages dans l'Orient médiévale", BCH 126(2), pp. 598-614.

Lécuyer, N. and Michaelides, D. (2004), "Archaeological survey at Potamia-Ayos Sozomenos", British School at Athens Studies 11, pp. 139-149.

Lefort, J., Morrisson, C., and Sodini, J.-P. (eds) (2005), Les Villages de l'Empire Byzantine IVe-XVe siècle. Paris: Boccard.

Leonard, J. (1995), "The Anchorage at Kioni", in J. Fejfer (ed.), (1995), Ancient Akamas: Settlement and Environment. Aarhus: Aarhus Universitetsforlag, pp. 133-170.

Levy-Rubin, M. (2011), Non Muslims in the Early Islamic Empire: From Surrender to Coexistence (Cambridge Studies in Islamic Civilization). Cambridge: Cambridge University Press.

Lightfoot, C.S. (2007), "Trade and industry in Byzantine Anatolia: The evidence from Amorion", DOP 61, pp. 269-286.

Lightfoot, C.S. (2009), “An Important Group of 7th-Century Coins from Amorium”, in O. Tekin (ed.), Ancient History, Numismatics and Epigraphy in the Mediterranean World: Studies in Memory of Clemens E. Bosch and Sabahat Atlan and in Honour of Nezahat Baydur. Istanbul: Zerobooks, pp. 223-226.

Lightfoot, C.S. (2012), "Business as Usual? Archaeological Evidence for Byzantine Commercial Enterprise at Amorium in the Seventh to Eleventh Centuries", in C. Morrisson (ed.), Trade and Markets in Byzantium (Dumbarton Oaks Byzantine Symposia and Colloquia). Washington, DC: Dumbarton Oaks, pp.177-191.

Lightfoot, C.S. and Lightfoot, M. (2007), Amorium: A Byzantine City in Anatolia - An Archaeological Guide (Homer Archaeological Guides). Istanbul: Homer Kitap.

Lilie, R.J. (1976), Die Byzantinische Reaktion auf die Ausbreitung der Araber: Studien zur Strukturwandlung des byzantinische Staates im 7. und 8. Jahrhundert, Miscellanea Byzantina Monacensia22. Munich: Inst. F. Byz. U. Neogräzistik.

Lilie, R.J. (1991), "Twelfth-century Byzantine-Turkish states", BF 16, pp. 35-51.

Lilie, R.J. (2005), "Zypern Zwischen Byzantinern und Arabern (7.-10. Jarhundert)", in J. Deckers, M.-E. Mitsou and S. Rogge (eds), Beiträge zur Kulturgeschichte Zyperns von der Spätantike bis zur Neuzeit. Symposium, Munchen 12.13. Juli 2002. Munster: Waxmann Verlag, pp. 65-90.

Lokin, J.H. (1986), "Administration and Jurisdiction in Cyprus in the Sixth Century C.E.", in Praktika tou deuterou diethnous Kypriologikou Synedriou (Lefkosia, 20-25 Apriliou 1982), Nicosia, Vol. 2, pp. 1-9.

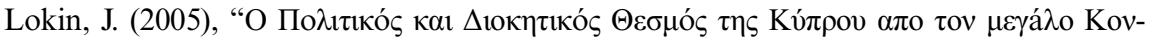

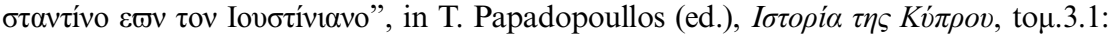

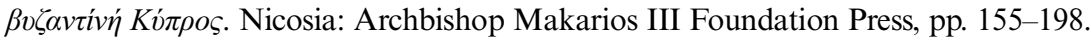

Lounghis, T.C. (2010), Byzantium in the Eastern Mediterranean: Safeguarding East Roman Identity (407-1204). Texts and Studies in the History of Cyprus, 63. Nicosia: Cyprus Research Center.

Lund, J. (2007), "Transport Amphorae as a Possible Source for the Land Use and Economic History of Akamas Peninsula, Western Cyprus", in M. Bonifay and J.-C. Tréglia (eds), LRCW2. Late Roman Coarse Wares. Cooking Wares and Amphorae in the Mediterranean: Archaeology and Archaeometry, 2 vols. Oxford: Archaeopress, Vol. 2, pp. 781-789.

Maas, M. (ed.) (2005), The Cambridge Companion to the Age of Justinian. Cambridge: Cambridge University Press. 


\section{Bibliography}

McClellan, M. and Rautman, M. (1995), "Where Have All the Farmers Gone? The Cypriot Countryside in the Seventh to the Tenth Centuries", in P. Wallace (ed.), Visitors, Immigrants and Invaders in Cyprus. Albany: Albany University Press, pp. 85-86.

McCormick, M. (2001), The Origins of European Economy: Communications and Commerce AD 300-900. Cambridge: Cambridge University Press.

McCormick, M. (2012), "Movements and Markets in the First Millennium. Information, Containers and Shipwrecks", in C. Morrisson (ed.), Trade and Markets in Byzantium (Dumbarton Oaks Byzantine Symposia and Colloquia). Washington, DC: Dumbarton Oaks, pp. 51-98.

Magness, J. (2003), The Archaeology of the Early Islamic Settlement in Palestine. Winona Lake: Eisenbrauns.

Magness, J. (2010), "Early Islamic Urbanism and Building Activity in Jerusalem and Hammath Gader", in J. Haldon (ed.), Money, Power and Politics in Early Islamic Syria: A Review of Current Debates. Burlington: Ashgate, pp. 147-163.

Malamut, E. (1988), Les îles de l'Empire byzantin. VIIIe-XIIe siècles, 2 vols. Paris: Sorbonne.

Mango, C. (1984a), "Cyprus, Carrefour du monde Byzantine", in C. Mango (ed.), Byzantium and its Image: History and Culture of the Byzantine Empire and its Heritage. London: Variorum, pp. 1-13.

Mango, C. (1984b), "A Byzantine Hagiographer at Work: Leontios of Neapolis", in I. Hutter (ed.), Byzanz und der Westen: Studien zur Kunst des europäischen Mittelalters. Vienna: Osterreische Akad. Der Wisseschen, pp. 25-41.

Mango, C. (ed.) (2002a), Oxford Dictionary of Byzantium. Oxford: Oxford University Press.

Mango, C. (2002b), "New Religion, Old Culture”, in C. Mango (ed.), Oxford Dictionary of Byzantium, pp. 96-119.

Mango, M.M. (ed.) (2009), Byzantine Trade 4th-12th Centuries: The Archaeology of Local, Regional and International Exchange. Papers of the Thirty-eighth Symposium of Byzantine Studies, St.John's College, University of Oxford, March 2004. Oxford: Oxford University Press.

Manning, S., Monks, S., Sewell, D., and Demesticha, S. (2000), "Late Roman 1 type amphora production at the late Roman site of Zygi Petrini, Cyprus", RDAC (2000), pp. 233-257.

Mansouri, M. (2001), Chypre dans les sources arabes médiévales. Nicosia: Cyprus Research Center.

Mansouri, M. (2014), "Chypre et les Arabes avant les Croisades à la Lumière des Sources Arabes", in C.A. Stewart, T.W. Davis, and A.-M. Weyl Carr (eds), Cyprus and the Balance of Empires: Art and Archaeology from Justinian I to the Coeur de Lion. Boston: CAARI, pp. 99-106.

Martinez Jiménez, J. (2013), "Crisis or Crises? The End of Roman Towns in Iberia, between the Late Roman and the Early Umayyad Period", in E.M. Van der Wilt, J. Martinez Jiménez andG. Petruccioli (eds), Tough Times: The Archaeology of Crisis and Recovery. Proceedings of the Graduate Archaeology at Oxford Conferences in 2012 and 2011. Oxford: Archaeopress, p. 77-90.

Mas Florit, C. and Cau Ontiveros, M.A. (2011), "From Roman to Byzantine: The rural occupation of eastern Mallorca (Balearic Island)", JMA 24(2), pp. 191-217.

Mascarò, J.N. and Moll Marcadal, B. (2013), "Sellos Byzantinos de Menorca. Un arconte mallorquin par las Baleares en el siglo VIII", Tharros Felix 5, pp. 556-561. 
Megaw, A.H.S. (1950a), "Three vaulted basilicas in Cyprus”, JHS 66, pp. 48-56.

Megaw, A.H.S. (1950b), "A Muslim tombstone from Paphos”, JRAS 82-3(3), pp. 108-109.

Megaw, A.H.S. (1958), "Archaeology in Cyprus”, $A R$ 1957, pp. 43-50.

Megaw, A.H.S. (1959), "Archaeology in Cyprus”, $A R$ 1958, pp. 25-34.

Megaw, A.H.S. (1964), A Brief History and Description of Kyrenia Castle. Nicosia: Department of Antiquities.

Megaw, A.H.S. (1972), "Supplementary excavations on a castle site at Paphos, Cyprus, 1970-1971”, DOP 26, pp. 322-343.

Megaw, A.H.S. (1974), "Byzantine architecture and decoration in Cyprus: Metropolitan or provincial", $D O P 28$, pp. 57-88.

Megaw, A.H.S. (1985), "Mosaici Parietali paleobizantini di Cipro", in XXXII Corso di Cultura sull' Arte Ravennate e Bizantina. Seminario Internazionale di studi su "Cipro e il Mediterraneo Orientale", Ravenna 23-30 Marzo 1985. Ravenna: Edizioni Danti, pp. $173-198$.

Megaw, A.H.S. (1985a), "Le Fortificazioni Bizantine a Cipro", in XXXII Corso di Cultura sull' Arte Ravennate e Bizantina. Seminario Internazionale di studi su "Cipro e il Mediterraneo Orientale”, Ravenna 23-30 Marzo 1985. Ravenna: Edizioni Danti, pp.199-229.

Megaw, A.H.S. (1985b), "Progress in Early Christian and Medieval Archaeology", in V. Karageorghis (ed.), Archaeology in Cyprus: 1960-1985. Nicosia: Leventis Foundation, pp. 292-298.

Megaw, A.H.S. (1986), "Betwixt Greeks and Saracens", in V. Karageorghis (ed.), Acts of the International Symposium "Cyprus between the Orient and the Occident". Nicosia: Department of Antiquities, pp. 505-519.

Megaw, A.H.S. (1988), "Reflections on Byzantine Paphos", in J. Chrysostomides (ed.), Kathegetria: Essays Presented to Joan Hussey for her 80th Birthday. Camberley: Porphirogenetos, pp.135-150.

Megaw, A.H.S. (2006), "The Campanopetra Reconsidered: The Pilgrimage Church of the Apostle Barnabas", in Elizabeth Jeffreys (ed.), Byzantine Style, Religion and Civilization, in Honour of Sir Steven Runciman. Cambridge: Cambridge University Press, pp. $394-414$.

Megaw, A.H.S. (eds) (2007), Kourion: Excavations in the Episcopal Precinct. Washington, DC: Dumbarton Oaks.

Megaw, A.H.S. and Hawkins, E.J. (1977), The Church of Panagia Kanakaria. Washington, DC: Dumbarton Oaks.

Merillees, R. (2009), "The modern history of the first Lambousa treasure of Byzantine silverware from Cyprus", Antiquaries Journal 89, pp. 1-15.

Metcalf, D.M. (2003), Coinage as Evidence for the Changing Prosperity of Cyprus in Medieval Times. Nicosia: Cyprus Research Center.

Metcalf, D.M. (2004), Byzantine Lead Seals from Cyprus (Texts and studies of the history of Cyprus47). Nicosia: Cyprus Research Center.

Metcalf, D.M. (2009), Byzantine Cyprus, 491-1191. Nicosia: Cyprus Research Center. Metcalf, D.M. (2013a), "Byzantine and Islamic Coins and Topography of Nea Paphos", in D. Michaelides (ed.), Epigraphy, Numismatics, Prosopography and History of Ancient Cyprus. Papers in honor of Ino Nicolaou. Uppsala: Åströms Förlag, pp. 70-83.

Metcalf, D.M. (2013b), "Imperial Involvement in the Governance of Cyprus during the years 635-965: Archaeological Evidence from the Lead Seals", in M. Parani and D. Michaelides (eds), The Archaeology of Late Antique and Byzantine Cyprus 


\section{Bibliography}

(4th-12th centuries AD): Conference in Honour of Athanasios Papageorghiou. Cahiers du Centre d'Études Chypriotes, 43, pp. 127-136.

Metcalf, D.M. (2014), "The North-South Divide in Byzantine Cyprus: Some Evidence from lead Seals and Coins", in C.A. Stewart, T.W. Davis, and A.-M. Weyl Carr (eds), Cyprus and the Balance of Empires: Art and Archaeology from Justinian I to the Coeur de Lion. Boston: CAARI, pp. 57-65.

Metcalf, D.M. and Pitsillides, A.G. (1995), "Islamic and Byzantine coins in Cyprus during the condominium centuries", EKEE 21, pp. 1-13.

Metcalf, D.M. and Pitsillides, A.G. (1997), "Some more finds of Islamic and Byzantine coins in Cyprus during the condominium centuries", EKEE 23, pp. 1-7.

Meyza, H. (2007), Nea Paphos V: Cypriot Red Slip Ware. Studies on a Late Roman Levantine Fine Ware. Warsaw: Archeobooks.

Michaelides, D. (1987), Cypriot Mosaics. Nicosia: Department of Antiquities.

Michaelides, D. (1993), "Opus Sectile in Cyprus", in A.A.M. Bryer and G.S. Gheorghallides (eds), The Sweet Land of Cyprus: Papers Given at the Twenty-Fifth Jubilee Spring Symposium of Byzantine Studies, Birmingham, March 1991. Nicosia: Cyprus Research Center, pp. 69-113.

Michaelides, D. (2001), "Archeologia Paleocristiana a Cipro", in XLIV Corso di Cultura sull'Arte Ravennate e Bizantina, Seminario internazionali di Studi sul tema: "Le grandi isole del Mediterraneo Orientale fra Tarda Antichità e Alto Medioevo Ravenna", 19-21 Settembre 1998. Ravenna: Edizione Danti, pp. 179-237.

Michaelides, D. (ed.) (2012), Historic Nicosia. Limassol: Rimal.

Michaelides, D. (ed.) (2013a), Epigraphy, Numismatics, Prosopography and History of Ancient Cyprus: Papers in honor of Ino Nicolaou. Uppsala: Åströms Förlag.

Michaelides, D. (2013b), "The Excavations of the University of Cyprus at 'Agioi Pente' of Yeroskipou”, in E. Zanini, P. Pergola, and D. Michaelidis (eds), The Insular System of Byzantine Mediterranean: Archaeology and History. Oxford: Archaeopress, pp. 87-97.

Michaelides, D. (2014), "The Significance of the Basilica at Agioi Pente of Yeroskipou", in C.A. Stewart, T.W. Davis, and A.-M. Weyl Carr (eds), Cyprus and the Balance of Empires: Art and Archaeology from Justinian I to the Coeur de Lion. Boston: CAARI, pp. 1-16.

Michaeolidou, L. (ed.) (2000), The Holy Bishopric of Morphou: 2000 Years of Art and Holiness. Nicosia: Bank of Cyprus Cultural Foundation.

Milwright, M. (2010), An Introduction to Islamic Archaeology. Edinburgh: Edinburgh University Press.

Mitchell, P. (2013), “Crisis? What Crisis?”, in E.M. Van der Wilt, J. Martinez Jiménez andG. Petruccioli (eds), Tough Times: The Archaeology of Crisis and Recovery. Proceedings of the Graduate Archaeology at Oxford Conferences in 2012 and 2011. Oxford: Archaeopress, pp. 3-11.

Mitford, T. (1950), "Some new inscriptions from early Christian Cyprus", Byz 20, pp. 116-125.

Mitford, T. (1980), "Roman Cyprus", in H. Temporini and W. Haase (eds), Aufstieg und Niedergang der Römischen Welt, Part II, Vol. 7.2. Berlin and New York: De Gruyter, pp. 1284-1384.

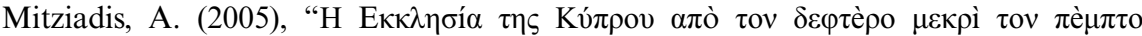

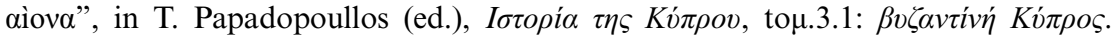
Nicosia: Archbishop Makarios III Foundation Press, pp. 107-128. 
Molinari, A. (2013), "Sicily between the 5th and the 10th Century", in E. Zanini, P. Pergola, and D. Michaelidis (eds), The Insular System of Byzantine Mediterranean: Archaeology and History. Oxford: Archaeopress, pp. 97-114.

Morales, E.M., Norris, M.B., Schwarz, A.W., and Watts, E.W. (2001), A Masterwork of Art: The David Plates, the Story of David and Goliath. New York: MET Publications.

Morrisson, C. (1998), "La Sicile byzantine: un lueur dans les siècle obscurs", Numismatica e Antichità Classiche Quaderni Ticinesi 27, pp. 307-334.

Morrisson, C. (2002), "Byzantine Money: Its Production and Circulation", in A. Laiou (ed.), The Economic History of Byzantium, 3 vols. Washington, DC: Dumbarton Oaks, pp. 909-966.

Morrisson, C. (2007), "La Numismatique, Source de'l'historie de Byzance”, Avó $v \pi$ tov

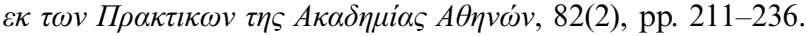

Morrisson, C. (ed.) (2012), Trade and Markets in Byzantium (Dumbarton Oaks Byzantine Symposia and Colloquia). Washington, DC: Dumbarton Oaks.

Morrisson, C. and Prigent, V. (2011), "La Monetazione in Sicilia nell'età Bizantina", in L. Travaini (ed.), Le Zecche italiane fino all'Unità. Rome: Treccani, pp. 427-434.

Morrisson, C. and Sodini, J.P. (2002), "The Sixth Century Economy", in A. Laiou (ed.), The Economic History of Byzantium, 3 vols. Washington, DC: Dumbarton Oaks, pp. 171-220.

Muthesius, A. (2002), "Essential Processes: Looms and Technical Aspects of Production of Silk Textiles", in A. Laiou (ed.), The Economic History of Byzantium, 3 vols. Washington, DC: Dumbarton Oaks, pp. 147-168.

Neal, D. (2010), The Basilica at Soloi: A Survey of the Buildings and the Mosaics. Nicosia: SAVE.

Nef, A. and Prigent, V. (2006), "Per una nuova storia dell'alto medioevo siciliano", Storica 35-6, pp. 9-63.

Nef, A. and Prigent, V. (eds) (2010), La Sicile byzantine de Byzance à l'Islam. Paris: Boccard.

Nesbitt, J. and Oikonomides, N. (1991), Catalogue of Byzantine Seals at Dumbarton Oaks and in the Fogg Museum of Art, 5 vols. Washington, DC: Dumbarton Oaks.

Nickerson, R. (1998), "Confirmation bias: A ubiquitous phenomenon in many guises", Review of General Psychology 2(2), pp. 175-220.

Nicolaou, D. (2013), "Le Strutture e l'arredo liturgico delle basiliche paelocristiane di Cipro", in E. Zanini, P. Pergola, and D. Michaelidis (eds), The Insular System of Byzantine Mediterranean: Archaeology and History. Oxford: Archaeopress, pp. 115-129.

de Nicolás, J. and Moll, B. (2013), "Sellos Bizantinos de Menorca. Un Arconte Mallorquin para las Baleares en el siglo VIII", Tharros Felix 5, pp. 537-572.

Noret, J. (1986), "L'Expédition canadienne à Soli et ses résultats pour l'intelligence et la datation de la Vie de S. Auxibe", $A B$ 104, pp. 445-452.

Noth, A. (1994), The Early Arabic Historical Tradition. Princeton: Princeton University Press.

O'Brien, S. (2013), "Parables of Decline: Popular Fears and the Use of Crises in Aegean Archaeological Interpretation", in E.M. Van der Wilt, J. Martinez Jiménez and G. Petruccioli (eds), Tough Times: The Archaeology of Crisis and Recovery. Proceedings of the Graduate Archaeology at Oxford Conferences in 2012 and 2011. Oxford: Archaeopress, pp. 13-22.

Oikonomides, N. (1972), Les Liste de Préséance Byzantines des IXe et Xe siècle. Paris: CNRS. 


\section{Bibliography}

Oikonomides, N. (2002), "The Role of Byzantine State in the Economy", in A. Laiou (ed.), The Economic History of Byzantium, 3 vols. Washington, DC: Dumbarton Oaks, pp. 973-1058.

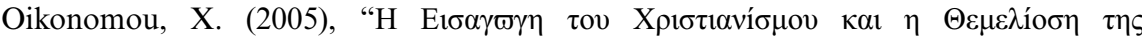

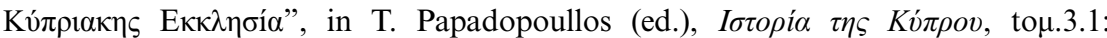
$\beta v \zeta \alpha v \tau i v \dot{~ K v} \pi \rho o \varsigma$. Nicosia: Archbishop Makarios III Foundation Press, pp. 23-105.

Özgünel, C. (2007), "Kibris Salamis Kazilarinin Dunu ve Bugunu”, AN 33, pp. 1-8.

Öztaner, S.H. (2007), "Colonnaded street at Salamis", $A N$ 33, pp. 101-109.

Öztaner, S.H. (2010), "Salamis-Constantia Kent Planlamasi üzerine Yeni Arastirmalar: Cardo ve Decumanus", $A N$ 36, pp. 199-214.

Palmer, J. (1993), The Seventh Century in the West Syrian Chronicles. Liverpool: Liverpool University Press.

Papacostas, T. (1999), "Byzantine Cyprus: The Testimony of its Churches 650-1200", unpublished DPhil thesis, 3 vols, University of Oxford.

Papacostas, T. (2001), "The Economy of Late Antique Cyprus", in S. Kingsley and M. Decker (eds), Economy and Exchange in the East Mediterranean during Late Antiquity. Proceedings of the Conference of Sommerville College, Oxford, 29th May 1991. Oxford: Oxbow, pp. 107-128.

Papacostas, T. (2002), "A tenth-century inscription from Syngrasis, Cyprus", BMGS 26, pp. 42-64.

Papacostas, T. (2012), "Byzantine Nicosia", in D. Michaelides (ed.), Historic Nicosia. Limassol: Rimal, pp. 77-109.

Papacostas, T. (2013), "Troodos Mountains of Cyprus in the Byzantine Period. Archaeology, Settlement and Economy", in M. Parani and D. Michaelides (eds), The Archaeology of Late Antique and Byzantine Cyprus (4th-12th centuries AD): Conference in Honour of Athanasios Papageorghiou. Cahiers du Centre d'Études Chypriotes, 43, pp. 175-200.

Papacostas, T. (2014), "Decoding Cyprus from Late Antiquity to the Renaissance: Discordant Visions, Saints and Sacred Topography", in C.A. Stewart, T.W. Davis, and A.-M. Weyl Carr (eds), Cyprus and the Balance of Empires: Art and Archaeology from Justinian I to the Coeur de Lion. Boston: CAARI, pp. 187-201.

Papacostas, T. (2015), "Neapolis - Nemesos - Limassol: The rise of a Byzantine settlement from Late Antiquity to the time of the Crusades," in A. Nicolaou-Konnari and C. Schabel (eds), Lemesos: A History of Limassol in Cyprus from Antiquity to the Ottoman Conquest. Newcastle-upon-Tyne: Cambridge Scholars Publishing, pp. 96-188.

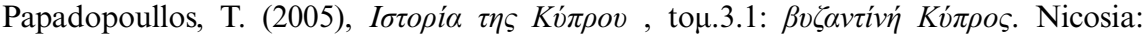
Archbishop Makarios III Foundation Press.

Papageorghiou, A. (1964), "Les premières incursions arabes à Chypre et leurs con-

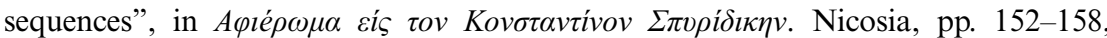
available at https://www.abebooks.com/servlet/BookDetailsPL?bi=538135003\&sea rchurl=tn\%3Daphieroma\%26sortby\%3D17 (accessed 17 February 2017).

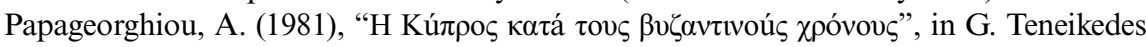
and G. Kranidiotes (eds), Kú pp. 33-78.

Papageorghiou, A. (1985a), "L'Architecture Paléochrétienne de Chypre", CCRB 22, pp. 299-334.

Papageorghiou, A. (1985b), "L'Architecture de le Période Byzantine à Chypre", $C C R B 22$, pp. $325-335$. 


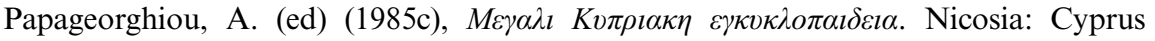
Research Center.

Papageorghiou, A. (1986), "Foreign Influence on the Early Christian Architecture in Cyprus", in V. Karageorghis (ed.), Acts of the International Archaeological Symposium "Cyprus between the Orient and the Occident", Nicosia 8-14 September 1985. Nicosia: Cyprus Research Center, pp. 490-504.

Papageorghiou, A. (1993), "Cities and Countryside at the End of Antiquity and the Beginning of the Middle Ages in Cyprus", in A.A.M. Bryer and G.S. Gheorghallides (eds), The Sweet Land of Cyprus: Papers Given at the Twenty-Fifth Jubilee Spring Symposium of Byzantine Studies, Birmingham, March 1991. Nicosia: Cyprus Research Center, pp.27-51.

Papageorghiou, A. (2002), "Byzantine Architecture (Fourth-Twelfth Century)", in L. Michaeolidou (ed.), The Holy Bishopric of Morphou: 2000 Years of Art and Holiness. Nicosia: Bank of Cyprus Cultural Foundation, pp. 63-70.

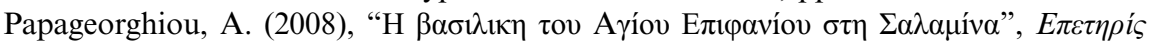

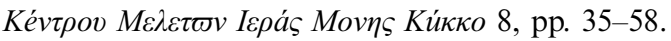

Papageorghiou, A. (2011), Christian Art in Turkish Occupied Cyprus. Nicosia: The Holy Archbishopric of Cyprus.

Papanikola-Bakirtzis, D. and Iacovou, M. (eds) (1998), Byzantine Medieval Cyprus. Nicosia: Bank of Cyprus Cultural Foundation.

Papathanassiou, K. (2002), "Metallurgy and Metalworking Techniques", in A. Laiou (ed.), The Economic History of Byzantium, 3 vols. Washington, DC: Dumbarton Oaks, pp. 121-127.

Parani, M. (2014), "Artisanal Production in Late Antique Cyprus", in M. Parani and D. Michaelides (eds), The Archaeology of Late Antique and Byzantine Cyprus (4th12th Centuries AD): Conference in Honour of Athanasios Papageorghiou. Cahiers du Centre d'Études Chypriotes, 43, pp. 131-138.

Parani, M. and Michaelides, D. (eds) (2013), The Archaeology of Late Antique and Byzantine Cyprus (4th-12th Centuries AD). Conference in Honour of Athanasios Papageorghiou. Cahiers du Centre d'Études Chypriotes, 43, pp. 11-328.

Patrich, J. (2011), "Caesarea in Transition: The Archaeological Evidence from the Southwest Zone (areas CC, KK, NN)", in K. Holum and H. Lapin (eds), Shaping the Middle East: Jews, Christians and Muslims in an Age of Transition, 400-800. Vol. 20 of Studies and Texts in Jewish History and Culture. Bethesda: University of Maryland Press, pp. 141-176.

Pazarli, M. (2009), "The Mediterranean islands in the Tabula Peutingeriana", e-Perimetron 4(2), pp. 101-116.

Pellegrino, E. (2002), "Le materiel céramique issu des fouilles menées en 1995 et 2000 sur l'acropole lycienne de Xanthos", Anatolia Antiqua 10, pp. 245-260.

Petre, J.S. (2012), Crusader Castles of Cyprus: The Fortifications of Cyprus under the Lusignans: 1191-1489 (Cyprus Research Centre. Texts and Studies in the History of Cyprus, 69). Nicosia: Cyprus Research Center.

Pirandello, L. (2005), The Late Mattia Pascal. New York: New York Review Books.

Pirenne, H. (1936), Mohammad and Charlemagne. New York: W. W. Norton.

Pouilloux, J. (1966), "Salamine de Chypre: Le site et ses problémes", Comptesrendus des séances de l'année 1965-Académie des incriptions et belles-lettres 110(2), pp. 232-256.

Pouilloux, J. (1987), Testimonia Salaminia 2. Corpus epigraphique [Salamine de Chypre 13]. Paris: Boccard. 


\section{Bibliography}

Pralong, A. (1994), "La Basilique de l'Acropole d'Amathonte", Rivista di Archeologia Cristiana 70, pp. 411-455.

Preiser-Kapeller, J. (2015), "Liquid Frontiers: A Relational Analysis of Maritime Asia Minor as a Religious Contact Zone in Thirteenth-Fifteenth Century", in A. Peacock, B. De Nicola, S. Nur Y1ldı (eds), Islam and Christianity in Medieval Anatolia. London: I.B.Tauris, pp. 117-146.

Prigent, V. (2006), "Le rôle des provinces d'Occident dans l'approvisionnement de Constantinople (618-717). Témoignages numismatiques et sigillographiques", Mélanges de l'École française de Rome. Moyen Âge 118(2), pp. 269-299.

Prigent, V. (2010a), "La Sicile de Constans II: l'apport des sources sigillographique", in A. Nef and V. Prigent (eds), La Sicile byzantine de Byzance à l'Islam. Paris: Boccard, pp. 157-187.

Prigent, V. (2010b), "La Sicilie Byzantine, Entre Papes et Empereurs (6eme-8eme siècle)", in D. Engels, L. Geis, and M. Leu (eds), Zwischen Ideal und Wirklichkeit. Herrschaft auf Sizilien von der Antike bis zum Spätmittelalter. Stuttgart: Franz Steiner Verlag, pp. 201-230.

Prigent, V. (2012), "Chypre entre Islam et Byzance", in J. Durand and D. Giovannoni (eds), Chypre entre Byzance et l'Occident (IVeme-XVIeme) siècle. Catalogue du l' exposition organisée par le musée du Louvre et le Département des Antiquités de Chypre à l'occasion de la Présidence Chypriote du Conseil de l'Union européenne. Paris: SOMOGY, pp. 79-93.

Prigent, V. (2013), "La circulation monétaire en Sicile (VIe-VIIe siècle)", in E. Zanini, P. Pergola, and D. Michaelidis (eds), The Insular System of Byzantine Mediterranean: Archaeology and History. Oxford: Archaeopress, pp. 139-161.

Procopiou, E. (2014), "The Katalymata ton Plakton: New Light from the Recent Archaeological Research in Cyprus", in C.A. Stewart, T.W. Davis, and A.-M. Weyl Carr (eds), Cyprus and the Balance of Empires: Art and Archaeology from Justinian I to the Coeur de Lion. Boston: CAARI, pp. 69-97.

Randall, I. (2013), "Continuity and Change in the Ceramic Data. The 'Byzantine problem' and Cyprus during the Treaty Centuries", in M. Parani and D. Michaelides (eds), The Archaeology of Late Antique and Byzantine Cyprus (4th-12th Centuries AD): Conference in Honour of Athanasios Papageorghiou. Cahiers du Centre d'Études Chypriotes, 43, pp. 273-284.

Rapp, C. (1993), "Epiphanus of Salamis: The Church Father as Saint", in A.A.M. Bryer and G.S. Gheorghallides (eds), The Sweet Land of Cyprus: Papers Given at the Twenty-Fifth Jubilee Spring Symposium of Byzantine Studies, Birmingham, March 1991. Nicosia: Cyprus Research Center, 169-187.

Rapp, C. (2014), "Christianity in Cyprus in the Fourth to Seventh Centuries", in C.A. Stewart, T.W. Davis, and A.-M. Weyl Carr (eds), Cyprus and the Balance of Empires: Art and Archaeology from Justinian I to the Coeur de Lion. Boston: CAARI, pp. 29-38.

Rapp, C. (2015), "Cypriot Hagiography in the Seventh Century: Patrons and Pur-

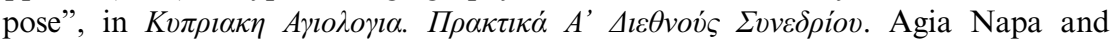
Paralimni: Iera Metropolis Constantia, pp. 397-412.

Rautman, M.L. (1990), “Archaeology and Byzantine studies”, Byzantinische Forschungen 15 , pp. $137-165$.

Rautman, M.L. (1998), "Handmade pottery and social change: The view from late Roman Cyprus", Journal of Mediterranean Archaeology 11(1), pp. 81-104.

Rautman, M.L. (2001), "Rural Society and Economy in Late Antique Cyprus", in J. W. Eadie and T.S. Burns (eds), Urban Centers and Rural Contexts in Late Antiquity. East Lansing: Michigan State University, pp. 241-262. 
Rautman, M.L. (2003), A Cypriot Village of Late Antiquity: Kalavasos-Kopetra in the Vasiliskos Valley. JRA Suppl. 52. Portsmouth, RI: Journal of Roman Archaeology, available at https://www.academia.edu/6526876/A_Cypriot_Village_ of_Late_Antiquity_Kalavasos-Kopetra_in_the_Vasilikos_Valley (accessed 18 February 2017).

Rautman, M.L. (2005), “The Village of Byzantine Cyprus”, in J. Lefort, C. Morrisson, and J.-P. Sodini (eds), Les Villages de l'Empire Byzantine IVe-XVe siècle. Paris: Boccard, pp. 453-463.

Rautman, M.L. (2014), "The Troodos in Twilight: A Provincial Landscape in the Time of Justinians", in C.A. Stewart, T.W. Davis, and A.-M. Weyl Carr (eds), Cyprus and the Balance of Empires: Art and Archaeology from Justinian I to the Coeur de Lion. Boston: CAARI, pp. 39-55.

Rautman, M.L.et al. (1999), "Amphoras and roof-tiles from late Roman Cyprus: A compositional study of calcareous ceramics from Kalavasos-Kopetra”, JRA 12, pp. 377-391.

Reimitz, H. (2014), "The Historian as Cultural Broker in the Late and Post Roman West", in A. Fischer and I. Wood (eds), Western Perspectives on the Mediterranean: Cultural Transfer in Late Antiquity and the Early Middle Ages, 400-800 AD. London: Bloomsbury, pp. 41-55.

Remsen, W. (2010), "The Survey of the Church", in M. Jones and A.M. Jones (eds), The Canopy of Heaven: The Cyborium of the Church of St. Mamas, Morphou. Nicosia: SAVE, pp. 71-101.

Robinson, C.F. (2003), Islamic Historiography. Cambridge: Cambridge University Press.

Rogge, S. and Grünbart, M. (eds) (2015), Medieval Cyprus: A Place of Cultural Encounters. "A Place of Cultural Encounter" Conference, Münster, 6-8 December 2012. Munster: Waxmann.

Rolfe, J.C. (1971-2), Ammianus Marcellinus, Loeb Classical Library, 3 vols (1935-1939), reprint. Cambridge, MA: Harvard University Press.

Rosen, W. (2007), Justinian's Flea: The First Great Plague and the End of the Roman Empire. London: Penguin.

Rosser, J. (1985), "Excavations at Saranda Kolones, Paphos, Cyprus, 1981-1983", DOP 39, pp. 81-95.

Roux, G. (1998), Salamine de Chypre XI. La Basilique de la Campanopétra. Paris: Boccard.

Rupp, D.W. (1981), "Canadian Paleopaphos survey project: Preliminary report of the 1979 season”, $R D A C$, pp. 251-268.

Rupp, D.W. (ed.) (1987), Western Cyprus: Connections. An Archaeological Symposium held at Brock University, St. Cahterines, Ontario, Canada. Gothenburg: Åströms Förlag.

Rupp, D.W. and Sørensen, L.W. (1993), The Land of Paphian Aphrodite, Vol. 2: The Canadian Paleopaphos Survey Project: Artifact and Ecofactual Studies. Gothenburg: Åströms Förlag.

Ryden, L. (1993), "Cyprus at the Time of the Condominium as Reflected in the Lives of Sts. Demetrianos and Constantine the Jew", in A.A.M. Bryer and G.S. Gheorghallides (eds), The Sweet Land of Cyprus: Papers Given at the Twenty-Fifth Jubilee Spring Symposium of Byzantine Studies, Birmingham, March 1991. Nicosia: Cyprus Research Center, pp. 189-202.

Sakellion, I. (1912-13), "Euaggelikos Keruxk", Roma e l'Oriente 5(27-30), pp. 225-366. 


\section{Bibliography}

Sarris, P. (2011), Empires of Faith: The Fall of Rome and the Rise of Islam, 500-700. Oxford: Oxford University Press.

Schulze, W.Schulze, I., and Leimenstoll, W. (2006), "Heraclian countermarks on Byzantine copper coins in seventh century Syria", Byzantine and Modern Greek Studies 30(1), pp. 1-27.

Ševčenko, N.P. and Moss, C. (eds) (1999), Medieval Cyprus: Studies in Art, Architecture and History in Memory of Doula Mouriki. Princeton: Princeton University Press.

Şevetoğlu, M., Tuncel, R., and Şahoğlu, V. (2015), "Protecting the cultural heritage of Cyprus: International laws and concerns", JEMAHS, 3(2), pp. 141-148.

Signes Codoñer, J. (2005), "Bizancio y las islas Baleares en los siglos VIII y IX", in R. Durán Tapia (ed.), Mallorca y Bizancio. Palma, pp. 45-101.

Signes Codoñer, J. (2007), Bis wann waren die Balearen byzantinisch?”, in K. Belke (ed.), Byzantina Mediterranea: Festschrift für Johannes Koder. Vienna: Böhlau, pp.597-604.

Sizgorich, T. (2004), "Narrative and Community in Islamic Late Antiquity", Past and Present 185, pp. 9-42.

Smadar Gabrieli, R., Jackson, M.P., and Kaldeli, A. (2007), "Stumbling into the Darkness: Trade and Life in Post-Roman Cyprus", in M. Bonifay and J.-C. Tréglia (eds), LRCW2. Late Roman Coarse Wares. Cooking Wares and Amphorae in the Mediterranean: Archaeology and Archaeometry, 2 vols. Oxford: Archaeopress, pp. 791-803.

Smith, J.S. (2005), Guide to Phlamoudi. New York: Columbia.

Sodini, J.P. (1973), "Epigraphica: Notes sur quelques inscriptions de Chypre", TM 5, pp. $327-384$

Sodini, J.P. (1988), "Les Inscriptions de l'Aqueduc de Kythrea à Salamine de Chypre”, in Eupsichia. Mélanges offers à Hélène Ahrweiler (Byzantina Sorbonensia, 16). Paris: Boccard, pp. 619-646.

Sophocleus, S. (1994), Icons of Cyprus: 7th-20th century. Nicosia: Center of Cultural Heritage.

Soteriou, G.A. (1931), "The early Christian and Byzantine remains of Cyprus",

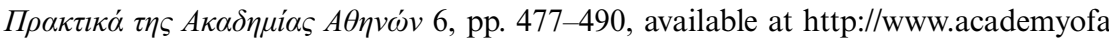
thens.gr/el/reports-minutes (accessed 18 February 2017).

Stewart, C.A. (2008), "Domes of Heaven: The Domed Basilicas of Cyprus", unpublished $\mathrm{PhD}$ dissertation, Indiana University.

Stewart, C.A. (2010), "The first vaulted church in Cyprus", JSAH 69(2), pp. $162-189$.

Stewart, C.A. (2014), "The Development of Byzantine Architecture in Cyprus", in C.A. Stewart, T.W. Davis, and A.-M. Weyl Carr (eds), Cyprus and the Balance of Empires: Art and Archaeology from Justinian I to the Coeur de Lion. Boston: CAARI, pp. 107-134.

Stewart, C.A. (2016), "Flying Buttress and Pointed Arch in Byzantine Cyprus", available at www.sas.upenn.edu/ancient/masons/Stweart-Flying_Buttresses.pdf (accessed 18 July 2016).

Stewart, C.A., Davis, T.W., and Weyl Carr, A.-M. (eds) (2014), Cyprus and the Balance of Empires: Art and Archaeology from Justinian I to the Coeur de Lion. Boston: CAARI.

Stylianou, A. and Stylianou, J. (1985), The Painted Churches of Cyprus: Treasures of Byzantine Art. London: Greek Communal Chamber. 
Talbot, C.H. (ed.) (1954), The Anglo-Saxon Missionaries in Germany: Being the Lives of SS. Willibrord, Boniface, Sturm, Leoba and Lebuin together with the Hodoeporicon of St. Willibald and a Selection from the Correspondence of St. Boniface. London: Sheed \& Ward.

Taxel, I. (2013), "The Byzantine-early Islamic transition on the Palestinian coastal plain: A re-evaluation of the archaeological evidence", Semitica et Classica 6, pp. $73-106$.

Taxel, I. (2013a), "Rural settlement processes in central Palestine, ca. 640-800 C.E.: The Ramals-Yavneh region as a case study", Bulletin of the American Schools of Oriental Research 369, pp. 157-199.

Taxel, I. and Fantalkin, A. (2011), "Egyptian coarse ware in early Islamic Palestine: Between commerce and migration", Al-Masaq. Islam and the Medieval Mediterranean 23(2), pp. 77-97.

Teall, J. (1959), "The grain supply of the Byzantine empire, 330-1025", DOP 13, pp. $87-139$.

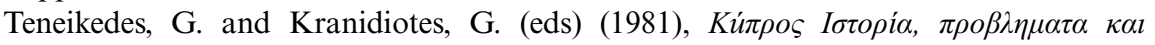

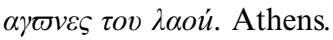

Touma, F. (2001), "Chypre: céramique et problèmrs", in E. Kountoura-Galaki (ed.), The Dark Centuries of Byzantium (7th-9th Centuries). Athens: National Hellenic Research Foundation, pp. 267-291.

Toumazou, M., Kardulias, N., and Counts, D. (eds) (2011), Crossroads and Boundaries: The Archaeology of Past and Present in the Malloura Valley, Cyprus. Boston: ASOR.

Treadgold, W. (1988), The Byzantine Revival 780-842. Stanford: Stanford University Press.

Tzougarakis, D. (1988), Byzantine Crete, from the 5th Century to the Venetian Conquest. Athens.

Valérian, D. (2014), "The Medieval Mediterranean", in P. Horden and S. Kinoshita (eds), A Companion to Mediterranean History (Wiley-Blackwell Companions to World History). Chichester: Wiley-Blackwell, pp. 77-90).

Vallejo Girvés, M. (2012), Hispania y Byzancio: Una relación desconoscida. Madrid: Akal.

Vanhaverbeke, H. and Waelkens, M. (2003), The Chora of Sagalassos: The Evolution of the Settlement Pattern from Prehistoric until Recent Times. Turnhout: Brepols.

Vanhaverbeke, H. et al. (2009), "What Happened after the 7th Century AD: A Different Perspective on Post-Roman Rural Anatolia”, Archaeology of the Countryside in Medieval Anatolia, pp. 177-191.

Van der Wilt, E.M., Martinez Jiménez, J. and Petruccioli, G. (eds) (2013), Tough Times: The Archaeology of Crisis and Recovery. Proceedings of the Graduate Archaeology at Oxford Conferences in 2012 and 2011. Oxford: Archaeopress.

Varinlioğlu, G. (2007), "Living in a marginal environment: Rural habitat and landscape in southeastern Isauria", DOP 61, pp. 287-317.

Veikou, M. (2015a), "Mediterranean Byzantine Ports and Harbors in the Complex Interplay between Environment and Society. Spatial, Socio-Economic and Cultural Considerations Based on Archeological Evidence from Greece, Cyprus and Asia Minor", in J. Preiser-Kapeller and F. Daim (eds), Harbours and Maritime Networks as Complex Adaptive Systems. Mainz: RGZM, pp. 39-61.

Veikou, M. (2015b), "One Island, three Capitals: Insularity and the Successive Relocations of the Capital of Cyprus from Late Antiquity to the Middle Ages", in S. Rogge 
and M. Grünbart (eds), Medieval Cyprus: A Place of Cultural Encounters. "A Place of Cultural Encounter”. Conference, Münster, 6-8 December 2012. Munster: Waxmann, pp. 357-373.

Vionis, A. (2013a), "Reading Art and Material Culture: Greeks, Slavs and Arabs in the Byzantine Aegean", in B. Crostini and S. La Porta (eds), Negotiating Co-Existence: Communities, Culture and Convivencia in Byzantine Society. Trier: Wissenschaftlicher Verlag Trier, pp. 103-127.

Vionis, A. (2013b), "Considering a Rural and Household Archaeology in the Byzantine Aegean: The Ceramic Spectrum", in J. Bintliff and M. Caroscio (eds), Pottery and Social Dynamics in the Mediterranean and Beyond in Medieval and Post-Medieval Times. Oxford: Archaeopress, pp. 25-40.

Von Wartburg, M. (2007), "Chronology and Stratigraphy of the Medieval Pottery of Cyprus: A Critical review”, in B. Böhlendorf-Arslan, A. Osman Uysal, and J. Witte-Orr (eds), Byzas 7. Çanak. Late Antique and Medieval Pottery and Tiles in Mediterranean Archaeological Contexts. Proceedings of the First International Symposium on Late Antique, Byzantine, Seljuk, and Ottoman Pottery and Tiles in Archaeological Context, Çaanakkale, 1-3 June 2005. Istanbul: Ege Yayınları, pp. 419-440.

Vroom, J. (2003), After Antiquity: Ceramics and Society in the Aegean from the 7th to the 20th Centuries A.C. A Case Study from Boeotia, Central Greece (Archaeological Studies Leiden University10.) Leiden: Leiden University Press.

Vroom, J. (2004), "Late Antique Pottery. Settlement and Trade in the Eastern Mediterranean: A preliminary Comparison of Ceramics from Limyra (Lycia) and Beotia", in W. Bowden, L. Lavan, and C. Machado (eds), Recent Research on Late Antique Countryside. Leiden: Brill, pp. 281-334.

Vroom, J. (2005), "New Light on 'Dark Age' Pottery: A Note on Finds in South-Western Turkey", in Rei Cretariae Romanae Favtorvm. Acta 39. Congressvus Vicesimvs qvartvus rei cretariae romanae favtorvm namvri et dvobvus lovaniis habitvus mmiv. Oxford: Oxbow, pp. 249-257.

Vroom, J. (2007), "Limyra in Lycia: Byzantine/Umayyad Pottery Finds from Excavations in the Eastern Part of the City", in L. Séverine (ed.), Céramiques antiques en Lycie (VIIe S. a.C. - VIIe S. p.C). Les produits et les marchés (Études16). Bordeaux: Ausonius, pp. 261-292.

Vroom, J. (2011), "The Other Dark Ages: Early Medieval Pottery Finds in the Aegean as an Archaeological Challenge", in R. Attoui (ed.), When Did Antiquity End? Archaeological Case Studies in Three Continents (BAR I.S.2268). Oxford: Archaeopress, pp. 137-158.

Vroom, J. (2012a), "Tea and Ceramics: New Perspectives on Byzantine Pottery from Limyra", in M. Seyer (ed.), 40 Jahre Grabung Limyra. Akten des Internationale Symposions. Wien, 3-5 Dezember 2009. Vienna: Österreichisches Archäologisches Institut, pp. 343-358.

Vroom, J. (2012b), "From One Coast to Another: Early Medieval Ceramics in the Southern Adriatic Region", in S. Gelichi and R. Hodges (eds), From One Sea to Another: Trading Places in the European and Mediterranean Early Middle Ages. Proceedings of the International Conference, Comacchio, 27th-29th March 2009. Turnhout: Brepols, pp. 353-391.

Wallace, P. (ed.) (1995), Visitors, Immigrants and Invaders in Cyprus. Albany: Albany University Press.

Walmsley, A. (2007), Early Islamic Syria: An Archaeological Assessment. London: Duckworth. 
Walmsley, A. (2008), "Economic developments and nature of settlement in the towns and countryside of Syria-Palestine, ca. 565-800", DOP 61, pp. 319-352.

Walmsley, A. (2010), "Coinage and Economy of Syria and Palestine in the Seventh and Eighth Centuries CE", in J. Haldon (ed.), The Palgrave Atlas of Byzantine History. New York: Palgrave, pp. 21-44.

Walmsley, A. (2012), "Regional Exchange and the Role of the Shop in Byzantine and Early Islamic Syria", in C. Morrisson (ed.), Trade and Markets in Byzantium (Dumbarton Oaks Byzantine Symposia and Colloquia). Washington, DC: Dumbarton Oaks, pp. 311-332.

Walsh, M.J.K., Edbury, P., and Coureas, N. (2012), Medieval and Renaissance Famagusta: Studies in Architecture, Art and History. Burlington: Ashgate.

Walsh, M.J.K., Kiss, T., and Coureas, N. (2014), Medieval and Renaissance Famagusta: Studies in Architecture, Art and History. Budapest: CEU.

Wellhausen, J. (2004), "Arab Wars with the Byzantines in the Umayyad Period", in M. Bonner (ed.), Arab-Byzantine Relations in Early Islamic Times. Aldershot: Ashgate, pp. 31-64.

White, R. (1991), The Middle Ground: Indians, Empires and Republics in the Great Lakes Region, 1650-1815: Cambridge: Cambridge University Press.

White, R. (2006), "Creative misunderstandings and new understandings", The William and Mary Quarterly, Third Series 63(1), pp. 9-14.

Whittow, M. (1996), The Making of Orthodox Byzantium. Cambridge: Cambridge University Press.

Wickham, C. (2004), "The Mediterranean around 800: On the brink of the second trade cycle", DOP 58, pp. 161-174.

Wickham, C. (2005), Framing the Early Middle Ages: Europe and Mediterranean 400-800. Oxford: Oxford University Press.

Wickham, C. (ed.) (2007), Marxist History-Writing for the Twenty-First Century (British Academy Occasional Papers). London: British Academy.

Wickham, C. (2009), The Inheritance of Rome Illuminating the Dark Ages 400-1000 (The Penguin History of Europe). London: Penguin Press.

Wineburg, S. (2012), "Thinking like a Historian", available at www.loc.gov/teachers/tp s/quarterly/historical_thinking/article.html (accessed 12 September 2013).

Wright, C.G. (1992), Ancient Buildings in Cyprus. Leiden: Brill.

Yannopoulos, P. (1983), "Le Couches populaires de la société Chypriote au VIIe siècles selon les sources locales et contemporaines", EKEE 12, pp. 79-85.

Young, S. (2007), "Glass", in A.H.S. Megaw (ed.), Kourion: Excavations in the Episcopal Precinct. Washington, DC: Dumbarton Oaks, pp. 485-512.

Yon, M. (ed.) (1980), Salamine de Chypre. Histoire et archéologie. État des recherches (Colloques Internationaux du CNRS578). Paris: CNRS.

Zanini, E. (1994), Le Italie Bizantine. Bari and Rome: Edipuglia.

Zanini, E. (2006), "Indagini nella'area del Quartiere Bizantino del Pythion di Gortina (Creta) Quarta relazione preliminare", Atti della Scuola Di Atene, Serie III, 6(2), pp. 889-914.

Zanini, E. (2007), "Archeologia dello status sociale nell'italia Bizantina: tracce, segni e modelli interpretative", in G.P. Brogiolo and A. Chavarria (eds), Archeologia e società fra Tardo Antico e Alto Medioevo. Padova: SAP, pp. 17-41.

Zanini, E. (2009a), "Città, microterritorio e macroterritorio (e mobilità degli uomini) nel Mediterraneo proto-bizantino: il caso di Gortina di Creta”, in G. Macchi (ed.), Geografie del popolamento: casi di studio, metodi, teorie. Siena: Edizioni Università, pp. 111-122. 


\section{Bibliography}

Zanini, E. (2009b), "La Ceramica del Quartiere Bizantino del Pythion di Gortina (Creta): Qualche approccio e spunto riflessivo", Facta 3, pp. 75-89.

Zanini, E. (2013a), "Creta in età Protobizantina: un quadro di sintesi regionale", in E. Zanini, P. Pergola, and D. Michaelidis (eds), The Insular System of Byzantine Mediterranean: Archaeology and History. Oxford: Archaeopress, pp. 173-190.

Zanini, E. (2013b), "Introduzione. Le ragioni di un seminario. Le ragioni di un libro", in E. Zanini, P. Pergola, and D. Michaelidis (eds), The Insular System of Byzantine Mediterranean: Archaeology and History. Oxford: Archaeopress, pp. 3-16.

Zanini, E., Pergola, P. and Michaelides, D. (eds) (2013), The Insular System of Byzantine Mediterranean: Archaeology and History. Oxford: Archaeopress.

Zavagno, L. (2009), Cities in transition: Urbanism in Byzantium between Late Antiquity and the Early Middle Ages (500-900 C.E.). Oxford: Archaeopress.

Zavagno, L. (2011), "Betwixt the Greeks and the Saracens': Coins and coinage in Cyprus in the seventh and eighth centuries", Byz 81, pp. 448-493.

Zavagno, L. (2011-12), "At the edge of two empires: The economy of Cyprus between late Antiquity and the early Middle Ages", DOP 65(6), pp. 121-156.

Zavagno, L. (2013), "Two hegemonies, one island: Cyprus as a 'Middle Ground' between the Byzantines and the Arabs (650-850 A.D.)", Reti Medievali - Rivista 14(2), pp. 3-32.

Zavagno, L. (2014), “A wonderful city of palms and dates': Salamis-Constantia in transition from late Antiquity to the early Middle Ages", MHR 29(2), pp. 111-138.

Zoroglu, L. (2005), "Roman Fine Wares in Cilicia: An Overview", in Rei Cretariae Romanae Favtorvm. Acta 39: Congressvus Vicesimvs quartvus rei cretariae romanae favtorvm namvri et dvobvus lovaniis habitvus mmiv. Oxford: Oxbow, pp. 243-248. 


\section{Index}

'Abd al-Mālik: caliph 77, 79, 82, 97

'Amr b. al-'As 73

Abbasid(s) 2, 37, 81, 84, 160, 164, 174, 184, 186

Abu Mena 163

Abu' al-Fīdā 120

Abu-1- A'war 138

Acre 75

Acropolitan Basilica 18; see also Amathos

Adriatic 35, 48, 168, 169

Aegean 6, 8, 9, 12, 18, 41, 48, 80, 85, $100,156,159,167,169,170,174$, 189 ; island 66; sea 5, 88, 127, 191

Africa(n) 67, 74, 80, 89, 115, 123, 163, $166,167,184,189$

Agapius 174

Agia Eirene: church of 124

Agia Mavra: church of 50

Agia Paraskevi: church of 24, 85, 100,185

Agia Salomon: church of 50, 137

Agia Trias: church of 121

Agia Varvara: church of 24, 85, 100, $121,133,145,158,159$

Agios Georgios: church of 68, 124-25, 156

Agios Kononas: church of 114, 123-24, 130

Agios Philon: church of 77, 93, 116, 120-21, 140, 165; see also Carpasia

Agios Tychonas: church of 114, 122

Akamas: church of 114, 116, 118, $123-24,127,161$

Akanthou 128

Alassa: basilica/church of 46, 123, 172

al-Balādhurī 52, 73-5, 78, 80-1, 86, 166,187
Albania 163

Aleppo 175

Alexander: monk 135

Alexandria 39, 65, 68-71, 73, 95-6, $124-5,156,185$

al-Idrīsi 130,185

al-Istakhrī 55187

al-Mas'udī 160, 165

al-Muqaddasī 9, 55, 86, 120, 159, 165, 175,185

al-Muqtadir: caliph 85, 182

al-Ṭabarī 74

al-Walīd: caliph 82, 165, 174

Amastris 141-2

Amathos 18, 42-3, 46, 50-1, 69, 75, $84,87,97,114-15,120-1,123$, $126,131,134,137,138-9,140-2$, 144-5, 157, 161-3, 167, 170, 174; basilica/church of 99,131 ; bishopric of 71,96

Ammianus Marcellinus 9, 67, 156, 161

Ammochostos 138; see also Famagusta

Amorium 142, 173, 174, 191

Anastasios Sinaite 84, 95, 143

Anastasius: emperor 137

Anatolia 41, 48, 95, 159, 163-4, 166, $167,173,186-7$; cities of 6 ; coast(line) 9, 166; plateau 5, 6, 12, 38, 73, 156, 174,191

Anemurium 95, 167

Ankara 142

annona 65-7, 70, 77, 118, 124, 156

Antalya 86, 95, 186; see also Attaleia

Antaradus 135

Anthemios: archbishop 135

Antioch 64, 66, 95

Antoninus Placentinus 95, 135

Aphendrika see Ourania-Aphendrika and Panagia Aphendrika 


\section{Index}

Apostolos Andreas: church of 115, 120

Arab 3, 5, 9-12, 18-20, 22, 25, 33-4, 37, $40-1,44,47,49,52,54-5,64-5,72-6$, 78, 80-7, 90, 92, 97-8, 100, 114, 120, $123,128,130,133-4,140,143,145$, $156,159,160,164-6,174,182,185-7$, 190; Byzantine relations 4, 9, 19, 32-3, $37-8,40-1,44,55,75,80,83,85,124$, 126, 164, 170, 188; conquest 1, 10, 55, $67,75,101,184,188,191$; raid 1-4, 7, 9-10, 18-21, 23-5, 30, 39, 40, 50, $51-2,54,64,67,69,72-9,84,86-7$, 93, 97, 116-17, 119, 123-4, 126, 128, $132,134,137-8,140-1,160-1,168$, 174, 181-2, 185

Arados island of (Aradians) 126

Arcadios: archbishop 69, 72, 96-7, 136

Arcadius: emperor 96

archontes: of Cyprus 33-4, 37, 44, 87-8, 90, 182; of Balearics 44, 87, 90; of Crete 88; of Malta 89; of Sardinia 44,87

Armenian(s) 52, 70

Artavasdos 84, 120, 169

Arwād see Arados

Arzanene 70

Asia Minor 6, 4-8, 86-7, 174, 186, 189

Asomatos: church of 121; see also Ourania-Aphendrika

Aspagurius: general 70

Athienou-Malloura 129

Attaleia 95, 187

Augustus: emperor 65

Avars 68, 70

Ba'albek 80, 164

Baghdad 84, 184-5

Balboura 167

Balearics 5, 10, 34, 40, 44, 81-2, 87, 89, 90-1, 145, 158-9, 191

Balkhī School 55

Barnabas: apostle 92, 95; church of see Salamis-Constantia

Basil I: emperor 52, 84, 182

Basil II: emperor 183

basilei agathoi 135

basilikon ploimon 86

Bath-Gymnasium see Salamis-Constantia

Beirut 135, 163, 169

Black Sea 40, 66, 141

Book of Curiosities 132, 183

Buffavento: castle of 67,120
Caesarea Maritima 47, 73

Cairo 167

Campania 169

Campanopetra: basilica/church see Salamis-Constantia

Canadian Palaephaphos Survey Project (CPSP) 116, 130

Cape Andreas 159

Cape Drepanon 68, 124

Cape Greco 115, 159

Cappadocia 6, 23, 128

Caria 66

Carpasia 93, 120-1, 137, 139, 140, 142, 190; see also Agios Philon

Carthage 65, 67-8, 166-7

Chios: island of see Emporion

Chytroi see Kythrea

Chrysopolitissa: basilica/church of see Paphos

Cilicia 48, 65, 67, 80, 124-5, 160-2, 167

Comacchio 169

Comes Orientis 66, 97

Condominium 2-3, 54, 81, 90

Constans II: emperor 39-40, 138

Constantine I: emperor 64, 66, 75, 135,144

Constantine IV: emperor 39-40

Constantine Porphyrogennetos 43, 52, 74, 81-2, 84, 87, 138, 182; see also De Administrando Imperio

Constantine the Jew: Life of $81,85,128$, 185; saint 38, 94-5, 187, 190

Constantine VI: emperor 40, 80, 141

Constantine VIII: emperor 183

Constantine: archbishop 94, 98, 101

Constantinople 8-10, 22, 25, 34, 39, 40, $44,48-9,54-5,64-5,66,68,70,73$, 77, 79-80, 86-7, 89, 97, 124, 127, 134, $156,159,160,166,167,169,174-5$, 185,191 ; patriarch of 64,97 ; siege of $77,80,86$

Constantius II: emperor 135

consularis 68

Crete (Cretan) 5-6, 10, 34, 40, 44, 48, 51, 65, 67, 77-8, 87-9, 90-1, 94, 134, 143, $146,156,161,163,166-7,173,182$, 185,191

Ctesiphon: battle of 70

cultural brokers 5, 43, 72, 82

Dalmatia 157, 168

Damascus 22, 25, 43, 80, 90, 116, 134, 159, 164; the Great Mosque of 86, 165

Damianos: archbishop 78, 93, 94 
Danube 66-8

David Plates 45, 69, 70-1, 118

De Administrando Imperio 43, 82, 138

Dead Sea 73, 79, 85, 174

Dhiorios: wares/pottery 45, 47, 118, 121, $157,163,167,168,169,185$

Dhiorios-Mersineri 120-1, 165, 169, 171-2

Diocese of the Orient 66

Diocletian: emperor 66, 78

dioketai 87

Dionysius of Tel-Mahre: Chronicle of 55,75-6, 78, 118, 138

Djerba 166

Ecumenical Council: third 95; quinisext 97; seventh 54, 83, 85, 94, 98, 101, 133, 138, 165;

Egypt, and Egyptian 8-10, 12, 21, 38, 40, $48,49,65-73,75,77,80,84,86,95$, 118, 124-5, 127, 137, 156-8, 163, $166,185,187,189,191$

Eleutherna 143

Emporion 167, 169

eparchs 87

Ephesus 6, 77, 95, 174

Epiphanios: archbishop/saint 92, 96, 135-6, 144, 183; basilica/church of see Salamis-Constantia; the monk 85 , 95, 143

episcoparum parochiae 96

Episkopi 114, 132-3; church of 100; see also Kourion

Euchaita 6

Eutychios of Alexandria 165

Ezousa 128

Famagusta 67, 132, 138

fitna 79,81

folles 68,71

Gabala 54, 83, 85, 94, 165

Galiporni-Kaleburnu 171

Gaul 35, 161,

Geniza: papyri of 186

George of Cyprus 113

Gortyn 6, 40, 88-9, 134, 143-4, 162, 167, 173-4

Greece (Greek(s)) 2, 5, 11, 18-19, 24, 36, $55,74,163,167,182,187$

Gregory the Great: pope 161

Hadūd al-'Ālam 130

Halan Sultan Tekke 74
Harun al-Rashid: caliph 84, 174

Hellespont 2, 4, 39, 82, 97

Heraclius: emperor $39-40,45,65,68-74$, 97, 136-8, 140

Hierocles Grammatikos 120

Hilarion: castle of 120 ; saint 92, 136

Himerios 182

Holy Land 24, 85, 92, 95, 96

Holy Sepulchre: church of 86, 99, 165

Homs 80, 164

Huilerie see Salamis-Constantia

hypatikos 68

Hytroi 120 ; see also Kythrea

ibn al-Athīr 74

ibn Hawqal 4, 55, 159, 185

ibn Hayyān: Jābir 130

ibn Khayyat 74

ibn Khurdādhbeh 120

ibn Sallām 81

iconoclasm (iconoclast) 15-16, 31, 36, $50,54,94,97-9,182$

illustrioi 43,82

Isaurian dynasty 42

Islam 4-6, 9, 15, 25, 33, 37, 41, 44, 54-5, $77,79,81-2,85-6,101,122,140,145$, $157-8,160,163-5,167-8,172,175$,

184, 191; Islamic Syria 30, 32, 117,172

isnād 37, 74

Italy $16,35,40,48,66,163$

Jerash 25, 144, 157, 169, 175

Jerome: saint 136 ,

Jerusalem $68-70,86,135,162-3,175$, 185 ,

John Kameniates 174

John Lydus 66

John Moschos 69

John of Nikiu: Saint Chronicle of 73

John the Almsgiver: Life of 53, 70;

Patriarch of Alexandria 69, 71, 96

Justinian I: emperor 7

Justinian II: emperor 22, 43, 77, 79, 82, $97,140,164$

Kalavasos-Kopetra 49, 114, 123-4, 127, $129,130,157,160,162,167-8,170$

Kantara: castle 67, 120

Karabisianoi 86

Karpas: peninsula 17, 23, 50, 67, 100, $116,121-4,126-7,130,133,140,142$, $145,147,190$

Kastamonou 142 
Keryneia 119; see also Kyrenia

Khirbat al-Mafjar 163

Khlorakas 125-7, 164

Khytrea: bishop of 150, 185

Kibyrrhaiotes 144

Kioni 124

Kition 75, 77, 120, 137, 142

kleisourarchoi 19

Kokokerizos: admiral 75

kommerkiarioi 33-4, 44; of Sicily 94

Kormakiti 115, 120; village 120

Kornos: Cave 120-1, 127, 128, 130, 168

Koroveia 24, 121

Kourion: city of 43, 47-8, 73, 77, 80, 94, $114,116,120,131-3,137,157,158$, 161-6, 168; basilica of 85,100 , 121,160

Koutsopetrika 121

Kyrenia 17, 50, 67, 72, 87, 93, 113-14, $118,120-1,127,132,137,142,169$, 183, 190; church of Chrysocava 128

Lambousa 75, 118; see also Lapethos

Lapethos 43, 45, 69, 75, 77, 87, $93,113,118,120,131,137,139$, 140,190

Larnaca 74, 87, 137, 142

Laterculus Veronensis 66

Lefkosia 113; see also Nicosia

Leo III: emperor 42, 86

Leo VI: emperor 86

Leontios of Neapolis 16, 53, 69

Leontios: emperor 87, 164

Libadia 121

Limassol 69, 132, 137-8, 163-4

Limyra 167

Lycia, (Lycian) 47, 80, 125, 160, 164, 167

Lymira 48, 158, 162-4, 167-8

Lythrangomi 98-9, 121

Magistrianos Paul 81

Malalas: Chronicle of 134

Malta 5-6, 10, 34, 40, 44, 48, 87, 89, 90-1, 169-70, 191

Mardaites 77, 80-1

Maroni-Petrera 121, 127

Masts: battle of 77

Maurice: emperor 70

Menas: archdeacon 69

Mesaoria Plain 65, 67, 118, 120, 128-9, 134

middle ground 4-5, 9, 22, 37, 43, 56, 83-4, 90, 92, 94, 101, 147, 175, $185-190$
Miletus 140

Mitsero-Politiko 45, 157

Moesia 66

Monophysism (monophysites) 72, 96

Monothelism (monothelists) 97

Morphou: bay of 75; church of 100 ; city of 75

Mu'āwiya: caliph 73-5, 78-81, 86, 126, 138,174

Muslims 4, 10, 12, 17, 25, 37, 38, 55, 72-5, 79-89, 94, 101, 146, 159-60, $162,165,174-5,183-7$

Naples 162, 170

Naxos 100,158 ; island of 85,158

Nea Justinianoupolis 4, 7, 18, 20, 30, 39, $82,97,138$

Nea Paphos 134, 161, 163; see also Paphos

Nicholaos Mystikos 185

Nicosia 19, 21, 113, 128, 132, 146, 182-3

Nikephoros Phokas: emperor 121, 169,181

Nikephoros: strategos 87

Niketas: droungarios and archon of Malta 89

Niketas Chalkoutzes 181

Nile 65, 156, 163, 167

Nonnos of Panopolis 67

Notitia Dignitatum 66

Nouzat al-Moushtaq 130

Orosius 22, 120

Ostrakine 162

Ourania-Aphendrika 121, 133, 137, 142, 145,154

Palaia-Paphos 120; see also Paphos

Paleopaphos 127; see also Paphos

Palermo 184

Palestine (Palestinian) 6-8, 10, 12, 21, 32-3, 37, 39, 41, 45, 47-9, 55, 65, 68, $70,72-3,75,79,80,84-5,95,101$, $117,119,126,134,137,142,144$, $157-8,160,163-5,168-9,173,175$, 184, 186-7, 191

Panagia Aphendrika: church of 145, 150, 158, 159; see also Sikhada

Panagia Angeloktistos: church of 50, 100

Panagia Chrysiotissa: church of 122, 143

Panagia Chrysopolitissa: church of 96 , 136, 144

Panagia Kanakaria: church of 50, 98, 99, 121 
Panagia Koroveia: church of 121

Panagia Kriniotissa: church of 120

Panagia Limeniotissa see Paphos

Panagia Pergaminiotissa: basilica/church of 128

Pantherios: bishop of Arados 126

Paphlagonia (Paphlagonian) 141

Paphos 7, 10, 18-19, 21, 23, 33, 42-3, 47-8, 50-52, 66, 73, 76, 80-1, 85, 95-6, 100, 114-16, 119-20, 122-6, 128-9, 131-2, 134, 136-7, 139-40, 142, 144-5, 157, 159, 162-3-166, 169, 172; Chrysopolitissa: basilica/church of 137, 140; House of Theseus 136; Limeniotissa basilica/church of 42,49 , 50-1, 76, 96, 100, 136, 145, 166;

Saranda Kolones 47, 52, 116, 145, 158, 162-7, 185, 187

Pedhios River 128, 134

Pedlenissos River 167

Pella 175, 144, 162

Peloponnesus 189

Pentadaktylos: mountains 17, 67, 120

Perge 167

Persia(n) 40, 45, 65, 68-73, 124, 130, 136, 140; war(s) 7, 45, 68, 70, 77, 135

Peutingerian Table 120

Phangoumeneis 43, 53, 82-4, 91, 144, 164,190

Phlamoudhi 122

Phocas: emperor 68

Phoenicia 65, 135

Pilgrims (pilgrimage) 5, 9, 24, 38, 54, $74,77,87,92,95,96,99,101,132$, $135-6,142-3,145,155,163-4,173$, 175,183

Pisidia(n) 160, 165, 167

Plutarchos 72, 97, 136

Polis-Arsinoe 41, 44, 50, 53, 76, 82, 87, 93, 97, 100, 116-17, 123, 129-31, 134, $137,142-4,172-3,185,187,191$

Politiko-Mitsero 127

Potamia-Agios 124, 127

Praefectus Pretorii 66

Pseira 89, 167

Pseudo-Dionysius of Tel-Mahre 55, 75-6, 78; Chronicle of 75, 118, 138

Quaestura Exercitus 66, 86

Qudama b. Ja'far 75

Ramla 184

Raqqa 84,174

ribāt 73
Rome 65, 136, 161, 169

Rutilius Palladius 67

Sagalassos 48, 125, 158

Saint Demetrianos 90; Life of 127, 185

Saint John 69, 97; Life of 53, 69, 70, 71,77

Saint Spyridon of Tremithous: Life of 53

Saint Stephen the Younger 71; Life of 53, 54, 98

Saint Therapon 137; Life of 75

Salamis-Constantia 7, 17, 18, 21-3, 33, 40-3, 46-7, 50-3, 68, 71-3, 75-7, 80, 9-4, 96, 99, 113-14, 116, 121, 123, 128-9, 131-6, 138-146, 157, 160, 162, 163-6, 170, 172-3, 183-185, 190; bath gymnasium 23, 133, 135, 144; church of Saint Barnabas 95-6, 135, 183; basilica/church of Campanopetra 96, 99, 133, 135, 139 143-4, 183; basilica/ church of Saint Epiphanios 24, 50, 76, 99, 121, 133, 135, 139, 143, 183;

Huilerie 42, 51, 133-5, 139, 144, 171-2; Vouta-cistern 136

Saracens 2, 24, 38, 84-5, 174, 187

Sarachane 46, 162

Saranda Kolones see Paphos

Sardica, Council of 77

Sardinia 5, 44, 87, 191

Sassanid(s) 71; empire 70

Schytopolis 144

Scythia 66

Seleucia 65, 95162

Seleucia Pieria 65

Seljuks 186

Sergios: archbishop 97, 136

Sicily (Sicilian) 5-6, 9-10, 15-16, 33-4, 40 44, 48, 80, 87-91, 94, 127, 146, 168-71, 173-4, 184-6, 191

Sidon 135,174

Sigillographic $31,32,42-4,71,76-7$, 81-2, 87-9, 91, 93, 125-7, 132, 135, $139,143,159,160,182-3$

Sikhada 121, 133, 145, 150, 158-9

Sinai 78 ,84, 95, 143, 162-3, 174

Soloi, basilica/church of $41,50,76,78$, 99,165 ; city of $17,40,43,48,50,75$, 77, 93, 96, 113, 116, 118-19, 120, 128-30, 132, 137, 166, 173, 190

Sophronius: Patriarch of Jerusalem 69

Sozomenos 123, 127

spatharioi 43,82

Spyridon of Tremithos: saint 77, 96; Life of 53, 77 


\section{Index}

Stephen of Byzantium 113

Stephen Protomartyr 71

Strabo 67, 161

strategos 38, 86-8, 93, 98, 144, 181-2

Sydney Cyprus Survey Project (SCSP) 118,130

Synekdemos 120

Synesios of Cyrene 67

Syngrasis 184

Syracuse 40, 88, 188

Syria 6-8, 10-12, 20-1, 30, 32-3, 36-7, $39-41,45,48-9,51,54-5,66,68,70$, $72-5,77,79,80,82-6,90,94-5,101$, $117,119,121-2,126,134,137,142$, $144,147,157,159,160,163-5$, $167-75,184-7,189,191$

Syria-Palestine $8-10,40-1,51,73,79$, $84-5,90,142,147,162-4,167-8,170$, 186,190

Tamassos 118, 120, 130; see also Politiko-Mitsero

themes 38, 52, 55, 84; of Crete 88; of Cyprus 84, 87, 182; of Kibyrreothi 86, 144; of Sicily 88, 90; of Trakesion 93, 98

Theodore of Paphos 77; Life of 50

Theodore: metropolitan of Tyre 94, 125

Theodoros: emperor 144

Theophanes 18, 37, 52-3 78, 81, 86, 97-8; Chronicle of 55, 77, 98

Theophilos: emperor 98

Theophylact Simocatta 70

thughür 73, 81
Tiberios III: emperor 42, 97

Tiberios: emperor 164

Tremetoussia 120; see also Trimithos

Trimithos 77, 94

Tychon: saint 136-7; Life of 96

Tyre 73, 94, 95, 125-6, 135, 174

Umayyad(s) 2, 5-6, 8, 10 ,12, 15, 20, 22, $33,37,47,48,51,53,55-6,77,79-81$, 84-5, 89-101, 140, 147, 157, 159-60, $163-5,169,174,186$

'Umar: caliph 74

'Uthmān: caliph 74

Umm ar-Rasas 172

Vandal 65

Vasilikos River 118; Valley 115,122

Venantius Fortunatus 161

Venetian (Venice) 35, 64, 169

Visigoth 34, 90

Willibald 95-6, 135, 143, 145; pilgrim 5,85

Xanthos 167

Xeropotamos River 128

Yalias River 67, 128-9, 134; valley 128,

Yarmuk: battle of 73

Yazid: caliph 80,81

Yeroskipou 24, 47, 114, 122

Zeno: emperor 135 